\title{
Characterization of the Hanford Site and Environs
}

Editor:

C. E. Cushing

Technical Contributors:
J. C. Chatters
T. M. Poston
D. L. Hadley
A. C. Rohay
D. J. Hoitink
R W. Wallace
S. J. Marsh

March 1991

Prepared for the U.S. Department of Energy under Contract DE-AC06-76RLO 1830

Pacific Northwest Laboratory

Operated for the U.S. Department of Energy

by Battelle Memorial Institute 


\title{
DISCLAIMER
}

This report was prepared as an account of work sponsored by an agency of the United States Government. Neither the United States Government nor any agency thereof, nor Battelle Memorial Institute, nor any of their employees, makes any warranty, expressedor implied, or assumesany legal liability or responsibility for the accuracy, completeness, or usefulnessof any information, apparatus, product, or processdisclosed, or represents that its use would not infringeprivately owned rights. Referenceherein to any specific commercial product, process, or service by trade name, trademark, manufacturer, or otherwisedoes not necessarily constitute or imply its endorsement, recommendation, or favoring by the United States Government or any agency thereof, or Battelle Memorial Institute. The views and opinions of authors expressedherein do not necessarily state or reflect those of the United States Government or any agency thereof.

\author{
PACIFIC NORTHWEST LABORATORY \\ operatedby \\ BATTELLEMEMORIAL INSTITUTE \\ for the \\ UNITED STATES DEPARTMENTOF ENERGY \\ under Contract DE-AC06-76RLO 1830
}

Printed in the United States of America

Available to DOE and DOE contractors from the

Office of Scientific and Technical Information, P.O. Box 62, Oak Ridge, TN 37831;

prices available from (615) 576-8401. FTS 626-8401.

Available to the public from the National Technical Information Service, U.S. Department of Commerce, 5285 Port Royal Rd., Springfield, VA 22161 


\section{CHARACTERIZATION OF THE HANFORD} SITE AND ENVIRONS

Editor:

C. E. Cushing

Technical Contributors:

J. C. Chatters

D. L. Hadley

D. J. Hoitink

S. J. Marsh

T. M. Poston

A. C. Rohay

R. W. Wallace

March 1991

Prepared for the U.S. Department of Energy under Contract DE-AC06-76RLO 1830

Pacific Northwest Laboratory

Richland, Washington 99352 



\section{PREFACE}

The U.S. Department of Energy (DOE) proposes to site, construct, and operate a new production reactor (NPR) intended to produce materials for the U.S. nuclear weapons program. The DOE has determined that this proposed action constitutes an action that may significantly affect the quality of the human environment; therefore, the DOE is preparing an environmental impact statement (EIS) to assess the potential impacts of the proposed action and reasonable alternatives on the human and natural environment. The NPR-EIS is being prepared in accordance with Section $102(2)(C)$ of the National Environmental Policy Act of 1969 (NEPA), as implemented in regulations (40 CR 1500-1508) promulgated by the Council on Environmental Quality (CEQ).

Argonne National Laboratory (ANL) has been selected as the lead contractor by the DOE to prepare the NPR-EIS. ANL is preparing the EIS and supporting documentation using information provided by the DOE (headquarters and operations offices), other federal agencies, state agencies, DOE contractors, and others. An NPR-EIS Support Project was established at Pacific Northwest Laboratory (PNL) to provide the necessary information about the Hanford Site and its environs to ANL.

The specific purposes of the PNL NPR-EIS Support Project are to 1) assist the DOE in planning and arranging public scoping meetings and hearings related to the NPR Draft EIS (DEIS); and 2) provide Hanford sitespecific input for the DEIS and the Final EIS (FEIS) to ANL.

Information on the potentially affected environment at the Hanford Site and. its environs was provided to $A N$ by $P N L$ in various submissions during $C Y$ 1989, and some of that information was consolidated into this report, which is considered to be supporting documentation for the NPR-EIS. 



\section{CONIENTS}

PREFACE ..................... . . $\mathbf{i} \mathbf{i} \mathbf{i}$

1.0 INTRODUCTION . . . . . . . . . . . . . . . . . 1.1

1.1 THEHANFORDSITE . . . . . . . . . . . . 1.1

1.2 REPORT ORGANIZATION $\ldots \ldots . . \cdots \cdot \ldots$

2.0 CLIMATE AND METEOROLOGY . . . . . . . . . . . . . . . 2.1

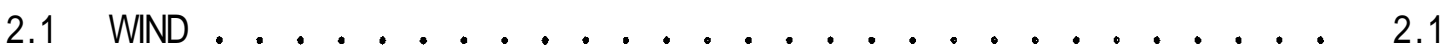

2.2 TEMPERATURE AND HUMIDITY . . . . . . . . . . . 2.5

2.3 PRECIPITATION . . . . . . . . . . . . . . . 2.7

2.4 FOG AND VISIBILITY . . . . . . . . . . . . . . 2.7

2.5 SEVERE WEATHER . . . . . . . . . . . . . 2.8

2.6 ATMOSPHERIC DISPERSION . . . . . . . . . . . . . . 2.9

2.7 AIR QUALITY . . . . . . . . . . . . 2.15

2.7.1 Major Stationary Emission Sources . . . . . . 2.16

2.7.2 Background Concentrations . . . . . . . . 2.17

3.0 GEOLOGY . . . . . . . . . . . . . . . . . 3.1

3.1 GEOLOGIC SETTING OF THE HANFORD SITE . . . . . . . . 3.1

3.1.1 Regional Geologic Setting .......... 3.1

3.1.2 Local Geologic Setting . . . . . . . . . . 3.4

3.2 LITHOSTRATIGRAPHY OF THE HANFORD SITE $\ldots \ldots \ldots$

3.2.1 Regional Lithostratigraphy . . . . . . . 3.7

3.2.2 Local Lithostratigraphy . . . . . . . . . . 3.10

3.3 GEOLOGIC STRUCTURES . . . . . . . . . . . . . . . 3.13

3.3.1 Regional Geologic Structures . . . . . . . 3.13

3.3.2 Local Geologic Structures ........... 3.16 


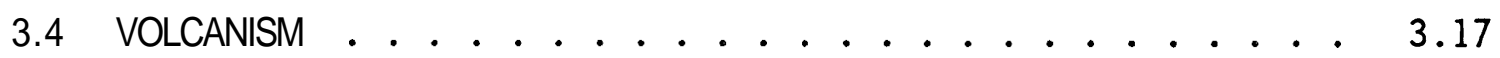

3.5 SEISMICITY . . . . . . . . . . . . . 3.18

3.6 SOlLS . . . . . . . . . . . . . . 3.29

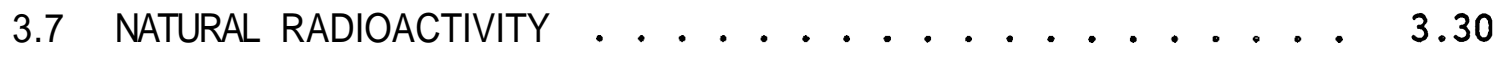

4.0 WATER RESOURCES . . . . . . . . . . . . . . . . . 4.1

4.1 HANFORD HYDROLOGY . . . . . . . . . . . . . 4.1

4.1.1 Surface Hydrology . . . . . . . . . . . 4.1

4.1 .2 Groundwater .............. 4.17

5.0 ECOLOGY . . . . . . . . . . . . . . . . . . 5.1

5.1 TERRESTRIAL ECOLOGY . . . . . . . . . . . . . 5.1

5.1 .1 Vegetation ................... 5.1

5.1 .2 Insects . . . . . . . . . . . 5.9

5.1 .3 Reptiles and Amphibians . . . . . . . . 5.9

5.1 .4 Birds ................. 5.10

5.1 .5 Mammals . . . . . . . . . . . 5.12

5.2 AQUATIC ECOLOGY . . . . . . . . . . . . . . . . . . . . . . 5.15

5.2.1 The Columbia River ........... 5.15

5.2 .2 Spring Streams . . . . . . . . . 5.21

5.2.3 Temporary Water Bodies . . . . . . . . 5.22

5.3 THREATENED AND ENDANGERED SPECIES . . . . . . . 5.22

5.3 .1 Plants .................. 5.23

5.3 .2 Birds . . . . . . . . . . . . 5.23

5.3.3 Candidate Species . . . . . . . . . . . 5.24

5.4 WILDLIFE REFUGES . . . . . . . . . . . . 5.24

6.0 HISTORICAL, ARCHAEOLOGICAL, AND CULTURAL RESOURCES . . . . . 6.1

6.1 INTRODUCTORYOVERVIEW . . . . . . . . . . . 6.1 
6.2 REGIONAL PREHISTORY. HISTORY. AND ETHNOGRAPHY . . . . . . 6.1

6.3 ARCHAEOLOGICAL SITES AND HISTORIC STRUCTURES $\ldots \ldots$.

6.4 NATIVE AMERICAN CULTURAL RESOURCES . . . . . . . 6.6

6.5 PALEONTOLOGICAL RESOURCES . . . . . . . . . . . 6.8

7.0 SOCIOECONOMICS .............................. 7.1

7.1 EMPLOYMENTAND INCOME . . . . . . . . . . . 7.1

7.1.1 DOE Contractors . . . . . . . . . 7.2

7.1.2 Washington Public Power Supply System . . . . . . 7.2

7.1 .3 Agriculture . . . . . . . . . . 7.2

7.1.4 Other Major Employers . . . . . . . . . 7.3

7.1 .5 Tourism . . . . . . . . . . . . 7.4

7.1 .6 Retirees ................. 7.4

7.1.7 Secondary Sector . . . . . . . . . 7.6

7.2 HANFORD AND THE LOCAL AND STATE ECONOMY . . . . . . 7.6

7.3 DEMOGRAPHY . . . . . . . . . . . . . . . . 7.7

7.4 HOUSING . . . . . . . . . . . . . . . 7.8

7.5 TRANSPORTATION . . . . . . . . . . . . . . 7.8

7.6 EdUCATIONAL SERVICES . . . . . . . . . 7.10

7.6.1 Primary and Secondary . . . . . . . . . 7.10

7.6.2 Post-Secondary . . . . . . . . . . . 7.10

7.7 HEALTH CARE AND HUMAN SERVICES . . . . . . . . 7.11

7.8 POLICE AND FIRE PROTECTION . . . . . . . . . . 7.12

7.9 PARKS AND RECREATION ..................... 7.12

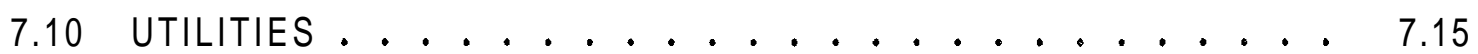

7.10 .1 Water . . . . . . . . . . 7.15 
7.10 .2 Electricity ............... 7.17

7.11 LAND USE . . . . . . . . . . . . . 7.18

7.12 OFFSITE HISTORICAL AND CULTURAL SITES . . . . . . . 7.19

7.13 VISUAL RESOURCES .................. 7.20

8.0 NOISE . . . . . . . . . . . . . . 8.1

8.1 BACKGROUND INFORMATION . . . . . . . . . . . 8.1

8.2 ENVIRONMENTAL NOISE REGULATIONS . . . . . . . . 8.2

8.3 HANFORD SITE SOND LEVELS . . . . . . . . . . 8.2

8.3.1 Skagit/Hanford Data ............ 8.3

8.3.2 BWIP Data .................... 8.3

8.3.3 NPR Site Data . . . . . . . . . . . 8.3

9.0 MONITORING AND MITIGATION PROCRAMS . . . . . . . . . . . 9.1

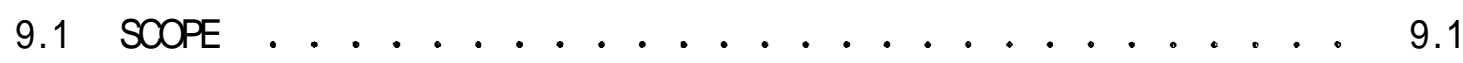

9.2 OBJECTIVES . . . . . . . . . . . . . . . 9.1

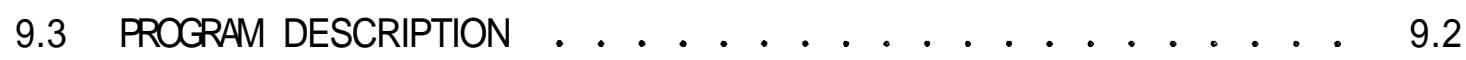

9.4 RELATED PROGRAMS. SPECIAL STUDIES. AND REPORTS . . . . . . 9.2

9.4.1 Operating Areas Monitoring . . . . . . . . . 9.3

9.4.2 Drinking Water Monitoring . . . . . . . . . 9.3

9.4.3 Resource Conservation and Recovery Act Monitoring . . 9.4

9.4.4 Comprehensive Environmental Response. Compensation. and Liability Act Assessments . . . . . . . . . 9.4

9.4.5 Nonradiological A ir Monitoring . . . . . . . . 9.5

9.4 .6 Wildlife Census .............. 9.5

9.5 AIR MONITORING . . . . . . . . . . . . . . 9.5

9.6 GRONDWATER MONTORING . . . . . . . . . . . . . . . . 9.6

9.7 SURFACE-WATER MONITORING . . . . . . . . . . . . . . 9.7 
9.8 FOOD AND FAPM PRODUCT MONITORING . . . . . . . . . . . 9.7

9.9 WILDLIFE MONITORING . . . . . . . . . . . . . . 9.7

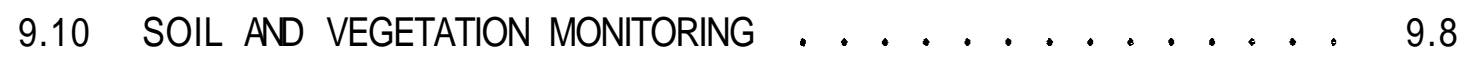

9.11 PENETRATING RADIATION MONITORING . . . . . . . . . . 9.8

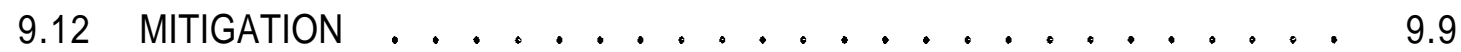

10.0 REFERENCES . . . . . . . . . . . . . . . . . . . 10.1 


\section{FIGURES}

1.1 Location of the Proposed NPR Site at Hanford . . . . . . . . 1.2

2.1 Hanford Site Wind Monitoring Network . . . . . . . . . . 2.2

2.2 Wind Roses for the Hanford Telemetry Network, 1979-1982 . . . . 2.3

2.3 Wind Roses for Hanford Telemetry Stations Closest to

Proposed NPR Site..................... 2.4

2.4 Major Stationary Emission Sources Within and Near the Hanford Site...................... 2.19

2.5 Ambient Air Monitoring Stations on the Hanford Site in 1987 . 2.20

3.1 Divisions of the Columbia Intermontane Province and Adjacent Provinces.................... 3.2

3.2 Index Map of Geologic Provinces . . . . . . . . . . . . . . . 3.4

3.3 Divisions of the Columbia Intermontane Province . . . . . . 3.5

3.4 Stratigraphic Nomenclature for the Columbia River Basalt Group of the Columbia Plateau . . . . . . . . . . . . 3.9

3.5 Stratigraphic Units Present in the Pasco Basin . . . . . . . 3.11

3.6 Structure Map of the Columbia Plateau . . . . . . . . . . . . . 3.14

3.7 Index Map to Structural Subprovinces of the Columbia Plateau as Defined by the Distribution of Columbia River Basalt

Flows East of the Cascade Range ................

3.8 Historical Seismicity of the Columbia Plateau and

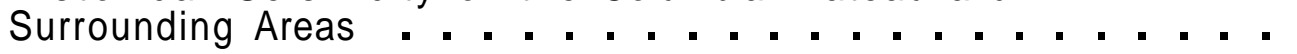

3.9 Recent Seismicity of the Columbia Plateau and Surrounding

Areas.

3.10 Soil Map of the Hanford Site . . . . . . . . . . . . . 3.33

4.1 Surface Water Bodies, Including Ephemeral Streams on the

Hanford Site........................... 4.2

4.2 Locations of Principal Dams Within the Columbia Plateau

Study Area. . . . . . . . . . . . . . . . . . . 
Hydrologic Basins Designated for the Washington State

Portion of the Columbia Plateau . . . . . . . . . 4.6

4.4 Flood Area for the Probable Maximum Flood . . . . . . . 4.8

4.5 Surface Water Intakes in the Pasco Basin and Vicinity . . . . . 4.14

4.6 Water Table Elevations for June 1988 . . . . . . . . . 4.21

4.7 Histograms Showing the Frequency of Transmissivity Occurrence within the Saddle Mountains Basalt and the Wanapum Basalt. Based on Specific Capacity of Wells . . . . . 4.25

4.8 Hanford Site Monitoring Well Locations . . . . . . . . . . . 4.31

4.9 Tritium Concentration in the Hanford Site Unconfined Aquifer in $1988 \ldots \ldots . \ldots . \ldots . . \ldots 2$

4.10 Nitrate Concentration in the Hanford Site Unconfined

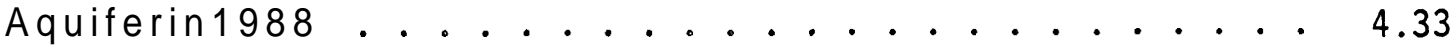

5.1 Major Facilities and Activities at Hanford . . . . . . . 5.2

5.2 Distribution of Vegetation Types on the Hanford Site . . . . 5.4

5.3 Food Web Centered on Cheatgrass ............ 5.7

5.4 Food Web Centered on Grasshoppers ............. 5.10

5.5 Food Web Centered on Chukar Partridge . . . . . . . 5.13

5.6 Food Web in the Columbia River . . . . . . . . . . 5.17

5.7 National and State Wildlife Refuges in the Vicinity of the Hanford Site ................ 5.25

6.1 Areas on the Hanford Site that are Considered Significant by Indian People................ . . 6.7

8.1 Noise Measurement Locations on the Hanford Site . . . . . . . 8.4 


\section{$\underline{\text { TABLES }}$}

2.1 Average Monthly and Annual Temperatures for Selected Hanford Telemetry Network Stations . . . . . . . . . 2.6

2.2 Number of Days with Fog by Season . . . . . . . . . 2.7

2.3 Estimates of Extreme Winds at Hanford Site . . . . . . . 2.8

2.4 Estimate of the Probability of Extreme Winds Associated with Tornados Striking a Point at Hanford ........ 2.9

2.5 Percent Frequency of Occurrence of Mixing-Layer Thickness by Season and Time of Day ............. 2.10

2.6 Percent Probabilities for Extended Periods of SurfaceBased Inversions.................. 2.10

2.7 Annual Average Atmospheric Dispersion Factors for the Skagit-Hanford Site for Ground-Level Releases Based on

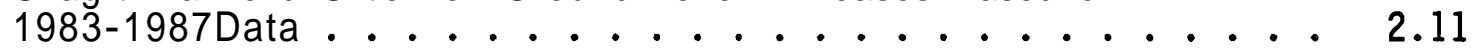

2.8 Annual Average Atmospheric Dispersion Factors for the 200-E Area for an 89-Meter Release Based on 1983-1987 Data . . . . 2.12

2.9 Annual Average Atmospheric Dispersion Factors for the 200-E Area for a Ground-Level Release Based on 1983-1987 Data . . . 2.13

2.10 Annual Average Atmospheric Dispersion Factors for the 400 Area for a Ground-Level Release Based on 1983-1987 Data . . . . . 2.14

2.11 Frequency of Occurrence of Emission Rates for Sources Within or Near the Hanford Site ............. 2.17

2.12 Emission Rates for Stationary Emission Sources Within the Hanford Site................. 2.18

2.13 Emission Rates for Major Stationary Sources Near the Hanford Site.................. 2.18

2.14 Results of Particulate Monitoring Near Hanford Site in 1987 . . 2.21

2.15 Ambient Air Quality Standards and Maximum Measured Background Concentrations of Significant Pollutants at the Hanford Site ..................

3.1 Historical Earthquake Catalog for Eastern Washington and Surrounding Areas through March 23, $1969 \ldots . . . . .3 .20$ 
3.2 Instrumental Earthquake Catalog for the Columbia Plateau and

Surrounding Area . . . . . . . . . . . . . 3.24

3.3 Soil Types on the Hanford Site . . . . . . . . . . . 3.31

3.4 Radionuclides Present in Hanford Soils in $1988 \ldots . . . . .3 .34$

4.1 Columbia River Water Quality Data for $1988 \ldots . . \ldots 4.10$

4.2 Summary of NPDES Data for $1988 \ldots \ldots . \ldots . \ldots . \ldots$

4.3 Radioactive Releases to the Environment for the 100 Areas

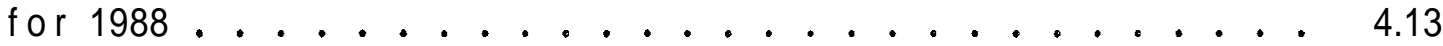

4.4 Summary of Downstream Surface-Water Uses for Columbia River

Water .................. 4.15

4.5 Radionuclide Concentrations in Onsite Ponds in 1988 . . . . 4.17

4.6 Representative Hydraulic Properties of the Unconfined

Aquifer in the Pasco Basin ............ 4.23

4.7 Volume of Hanford Site 200 Areas Liquid Effluents Discharged

to Radioactive Disposal Facilities in $1988 \ldots . . . . .4 .27$

4.8 Nonradioactive Indicators in Radioactive Liquid Effluents in the Hanford 200 Area During 1988 . . . . . . . . . 4.28

5.1 Prominent Vegetation on the Hanford Site . . . . . . . 5.5

5.2 Amphibians and Reptiles Occurring on the Hanford Site . . . . 5.11

5.3 Partial List of the Birds Found on the Hanford Site . . . . . 5.12

5.4 List of Mammals Occurring on the Hanford Site . . . . . . 5.14

5.5 Fish Species in the Hanford Reach of the Columbia River . . . 5.20

5.6 Threatened $(\mathrm{T})$ and Endangered $(\mathrm{E})$ Species . . . . . . 5.22

5.7 Candidate Species . . . . . . . . . . . . . . 5.24

6.1 Archaeological Surveys Conducted in the Proposed NPR Area of the Hanford Site . . . . . . . . . . . . 6.5

7.1 Government Retirement Payments in Benton and Franklin

Counties. 1986.................. 7.5

7.2 Total Units and Occupancy Rates . . . . . . . . 7.9 
Examples of Human Services Facilities and Organizations

in the Tri-Cities .................... 7.13

7.4 Pol ice Personnel in Tri-Cities, 1988............. . 7.14

7.5 Fire Protection in Tri-Cities, 1988 . . . . . . . . . 7.14

7.6 Violent and Property Crimes, 1988 . . . . . . . . . . . . 7.14

7.7 Examples of Physical Recreational Facilities Available in the Tri-Cities .................. 7.16

7.8 Washington State Register of Historic Places in Benton and Frankl in Counties ................... 7.20

8.1 Applicable State Noise Limitations for the Hanford Site Based on Source and Receptor EDNA Designation . . . . . . . . 8.2

8.2 Background Noise Level s Measure at Isolated Areas . . . . . . . 8.5

9.1 Environmental Sample Types and Measurement Locations, 1987 . . 9.3 


\section{$1.0 \quad$ INTRODUCTION}

\subsection{THE HANFORD SITE}

The Hanford Site lies within the semiarid Pasco Basin of the Columbia Plateau in southeastern Washington State. The Hanford Site, which extends about $50 \mathrm{~km}$ north to south and $40 \mathrm{~km}$ east to west, occupies an area of about $1,450 \mathrm{~km}^{2}$ north of the confluence of the Yakima and Columbia Rivers. This large area, with restricted public access, provides a buffer for the smaller areas currently used for production of nuclear materials, research, and waste management and disposal. The Columbia River flows through the northern part of the Hanford Site, and turning south, it forms part of the site's eastern boundary. The Yakima River runs along part of the southern boundary and joins the Columbia River below the city of Richland, which bounds the Hanford Site on the southeast. The Rattlesnake Hills, the Yakima Ridge, and Umtanum Ridge form the southwestern and western boundaries. The Saddle Mountains form the northern boundary of the Hanford Site. Two small east-west ridges, Gable Butte and Gable Mountain, rise above the plateau of the central part of the Hanford Site. Adjoining lands to the west, north, and east are principally range and agricultural land. The cities of Richland, Kennewick, and Pasco (the Tri-Cities) comprise the nearest population center and are located southeast of the Hanford Site.

The proposed site for the NPR at Hanford is located within a triangularshaped area that includes the Fast Flux Test Facility (FFTF), the Washington Public Power Supply System (WPPSS) Nuclear Plant 1 (WNP-1) site, and the Skagit/Hanford Nuclear Plant site. The Skagit/Hanford Nuclear Plant was proposed but never built. Some NPR facilities would be located in the 200 Areas of the Hanford Site. Figure 1.1 shows the region that includes the proposed NPR site at Hanford.

\subsection{REPORT ORGANIZATION}

This report contains a description of most aspects of the environment at the Hanford Site. The report is organized into 10 major chapters, including 


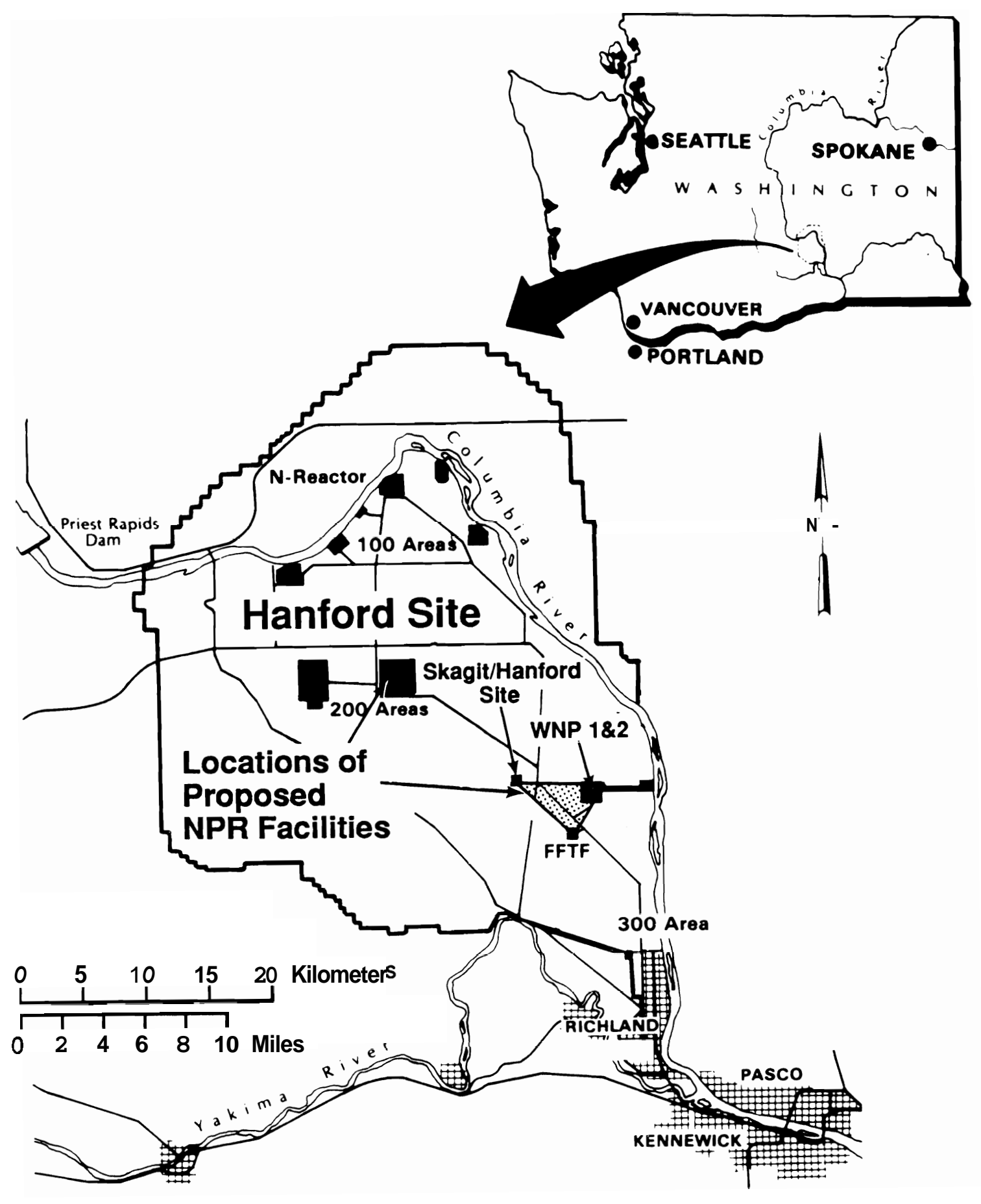

FIGURE 1.1. Location of the Proposed NPR Site at Hanford 
this introductory chapter. Each chapter is subdivided as necessary to provide organizational logic, and information is presented in graphical and/or tabular form as appropriate to aid the reader in understanding the narrative. Major chapters are dedicated to discussions of Climate and Meteorology (Chapter 2.0) ; Geology (Chapter 3.0) ; Water Resources (Chapter 4.0) ; Ecology (Chapter 5.0); Historical, Archaeological, and Cultural Resources (Chapter 6.0) ; Socioeconomics (Chapter 7.0) ; Noise (Chapter 8.0); Monitoring and Mitigation Activities (Chapter 9.0); and References (Chapter 10.0). 



\subsection{CLIMATE AND MEIBOROLOGY}

The Cascade Mountains beyond Yakima to the west greatly influence the climate of the Hanford Site due, in part, to the rain shadow effect caused by this range. The Cascade Mountains also serve as a source of cold air drainage, which has a considerable effect on the wind regime on the site.

Climatological data are available for the Hanford Meteorological Station (HMS), which is located between the 200 Areas. Data have been collected at the HMS since 1945. Temperature and precipitation data are also available from nearby locations for the period from 1912 through 1943. A summary of these data through 1980 was published by Stone et al. (1983). Data from the HW are representative of the general climatic conditions for the region and describe the specific climate of the 200-Area Plateau. There are local variations in the topography of the Hanford Site that may cause some aspects of the climatic conditions at parts of the site to differ significantly from the conditions at the HMS. For example, winds near the Columbia River are different than those at the HMS. Similarly, precipitation along the slopes of the Rattlesnake Hills differ dramatically from that at the HMS.

\subsection{WIND}

Wind data are collected at the HM at the surface $(2.1 \mathrm{~m}$ above the ground) and then at the 15.2-, 30.5-, 61.0-, 91.4-, and 121.9-m levels of a 125-m tower. Three 60-m towers, with wind measuring instruments at the 10-, 25-, and 60-m levels, are located in the 300, 400, and 100-N Areas. In addition, instruments on 21 9.1-m towers distributed on and around the Hanford Site (Figure 2.1) provide supplementary data for defining wind patterns.

Prevailing wind directions on the 200-Area Plateau are from the northwest in all months of the year (Figure 2.2). Secondary maxima occur for southwesterly winds. Summaries of wind direction indicate that winds from the northwest quadrant occur most often during the winter and summer. During the spring and fall, the frequency of southwesterly winds increases with a 


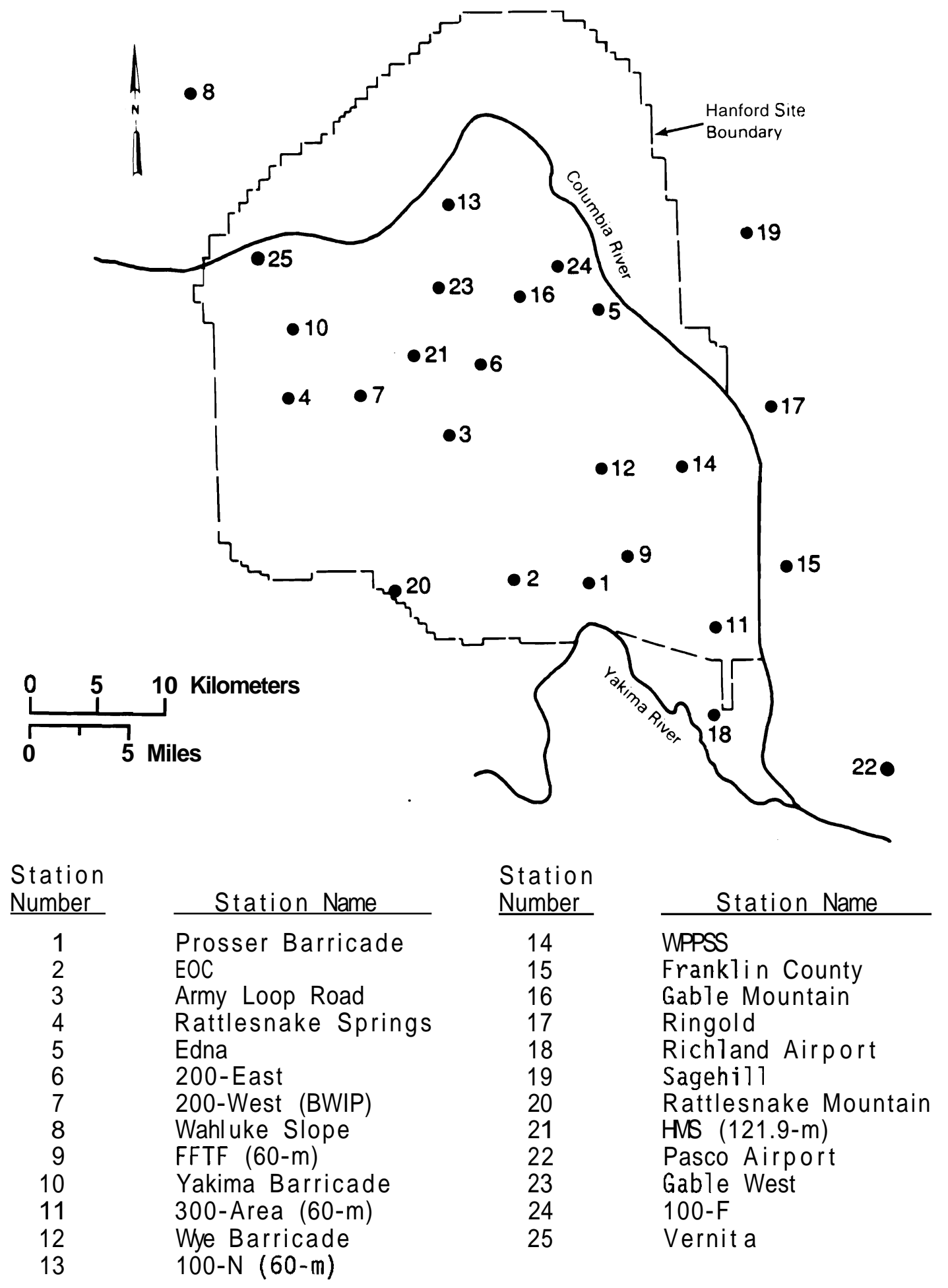

NOTE: All network stations are $9.1 \mathrm{~m}$ in height unless otherwise indicated.

FIGURE 2.1. Hanford Site Wind Monitoring Network 


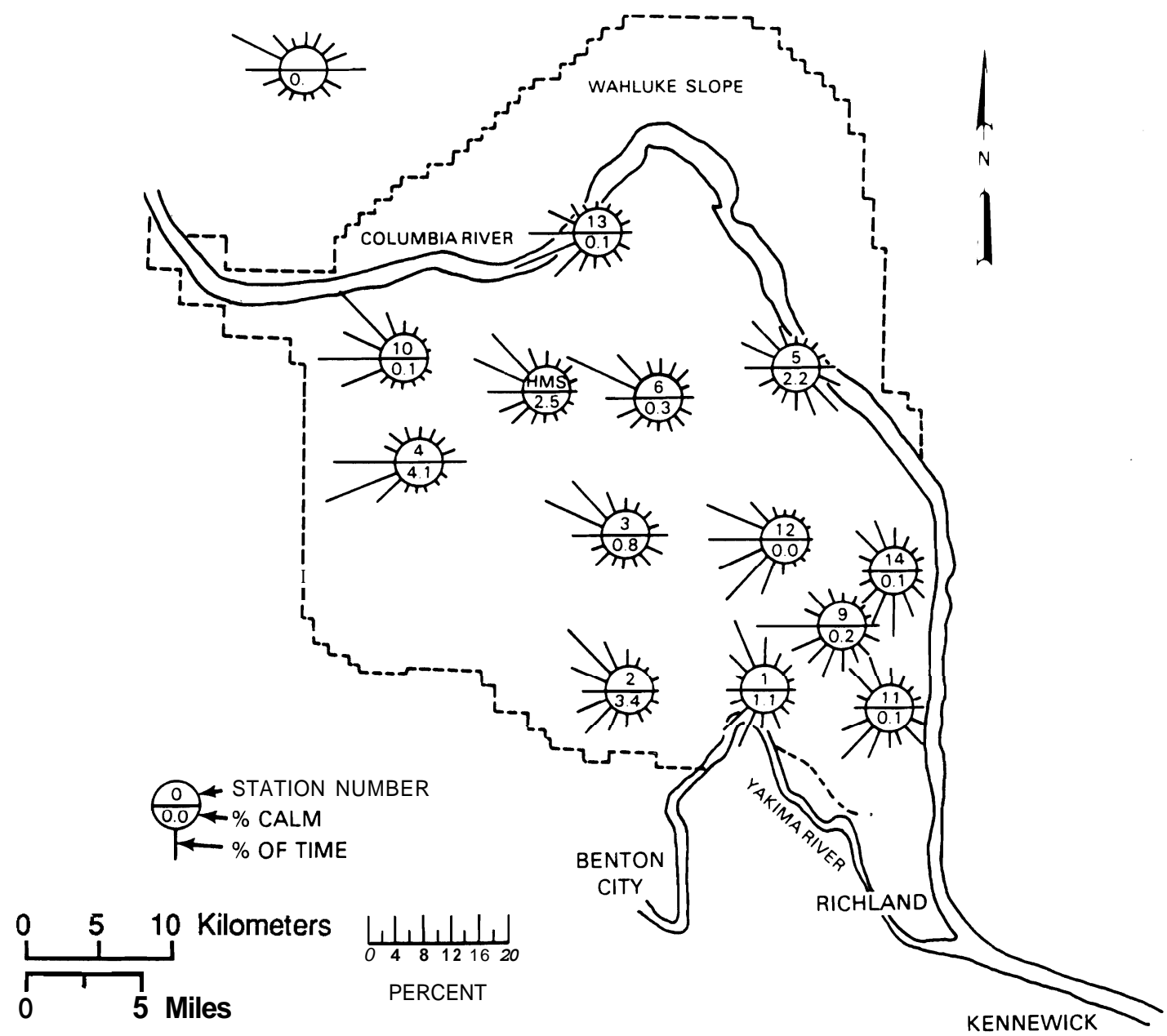

FIGURE 2.2. Wind Roses for the Hanford Telemetry Network, 1979-1982. The point of each rose represents the directions from which the winds come (Stone et al. 1983).

corresponding decrease in northwest flow. Winds blowing from other directions (e.g., northeast) display minimal variation from month to month.

Monthly and annual joint frequency distributions of wind direction versus wind speed for the HS are given in Stone et al. (1983). Monthly average wind speeds are lowest during the winter months, averaging 10 to $11 \mathrm{~km} / \mathrm{h}$, and highest during the summer, averaging 14 to $16 \mathrm{~km} / \mathrm{h}$. Wind speeds that are well above average are usually associated with southwesterly winds. However, 
the summertime drainage winds are generally northwesterly and frequently reach $50 \mathrm{~km} / \mathrm{h}$. These winds are most prevalent over the northern portion of the Hanford Site.

Updated wind roses are provided in Figure 2.3 for Stations 1, 3, 5, 9, 12, and 14 (these stations being the closest to the proposed NPR site).

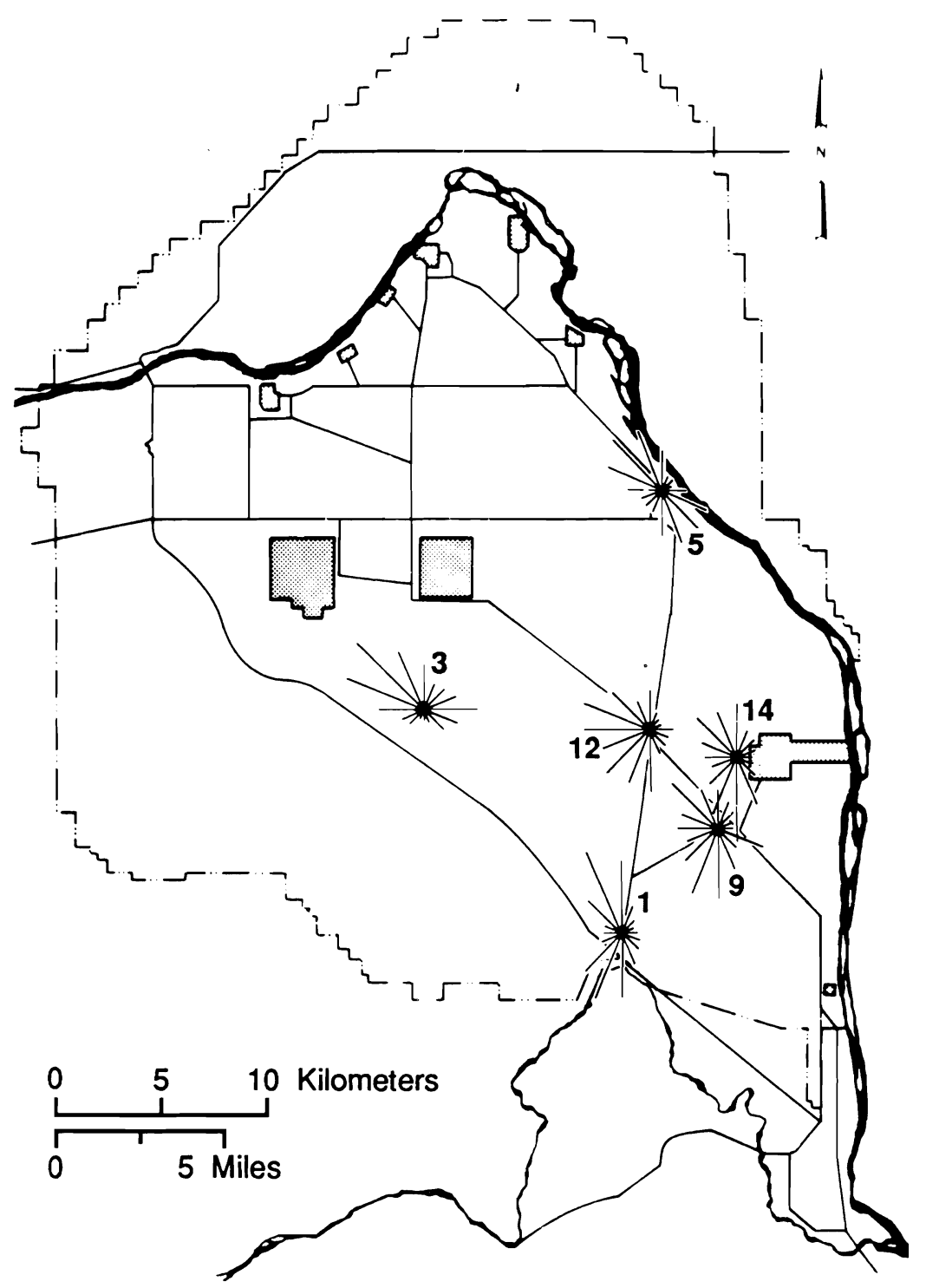

FIGURE 2.3. Wind Roses for Hanford Telemetry Stations Closest to Proposed NPR Site. (The point of each rose represents the directions from which the winds blow, and the length is proportional to the frequency of occurrence from a particular direction. Based upon data from January 1, 1980 to November 4, 1988.) 
These data cover the time period from January 1980 through mid-November 1988 , and as expected, these wind roses, which are based on a 9-year data set, are very similar to those in Figure 2.2, which are based on a 3-year data set.

The winds over the proposed NPR site are influenced by two major topographical features--Rattlesnake Mountain to the southwest and west, and the Columbia River to the east and north. The stations to the north of Rattlesnake Mountain (Figure 2.3; Stations 1, 3, and 12) show a high frequency of

winds from the west-northwest through north-northwest. Flow around the eastern end of Rattlesnake Mountain tends to produce a high frequency of moderate to strong south-to-southwest winds in this area (Figure 2.3; Stations 1, 9, 12, and 14). The Columbia River tends to force upriver and downriver flows to be parallel to the river; thus, an upriver flow tends to be southerly or slightly southeasterly, while downriver flows either caused by synoptic pressure gradients or thermal circulations tend to bend from the northwest through the north (Figure 2.3; Stations 5 and 14).

\subsection{TEMPERATURE AND HUMIDITY}

Temperature measurements are made at the 0.9-, 9.1-, 15.2-, 30.5-, 61.0-, 76.2- 91.4- and 121.9-m levels of the 125-m tower at the HMS. As of May 1987, temperatures are also measured at the 2-m level on the 21 9.1-m towers located on and around the Hanford Site. The three 60-m towers have temperature measuring instruments at the 2-, 10- and 60-m levels. The temperature data from the 9.1- and 60-m towers are telemetered to the HMS.

Diurnal and monthly averages and extremes of temperature, dew point, and humidity are contained in Stone et al. (1983). Ranges of daily maximum and minimum temperatures vary from normal maxima of $2{ }^{\circ} \mathrm{C}$ in early January to $35^{\circ} \mathrm{C}$ in late July. There are, on the average, 55 days during the summer months with maximum temperatures greater than or equal to $32^{\circ} \mathrm{C}$ and 13 days with maxima greater than or equal to $38^{\circ} \mathrm{C}$. From mid-November through mid-March, average minimum temperatures are less than or equal to $0^{\circ} \mathrm{C}$ with the minima in early January averaging $-6^{\circ} \mathrm{C}$. During the winter, there are an average of 4 days with minimum temperatures less than or equal to $-18^{\circ} \mathrm{C}$; however, only about one winter in two experiences such temperatures. The record maximum 
temperature is $46^{\circ} \mathrm{C}$, and the record minimum temperature is $-32.8^{\circ} \mathrm{C}$. For the period 1912 through 1980, the average monthly temperatures ranged from a low of $-1.5^{\circ} \mathrm{C}$ in January to a high of $24.7^{\circ} \mathrm{C}$ in July. During the winter, the highest monthly average temperature at the $\mathrm{HMS}$ was $6.9^{\circ} \mathrm{C}$, and the record lowest was $-5.9^{\circ} \mathrm{C}$; both having occurred during February. During the summer, the record maximum monthly average temperature was $27.9^{\circ} \mathrm{C}$ (in $\mathrm{July}$ ), and the record lowest was $17.2{ }^{\circ} \mathrm{C}$ (in June).

Table 2.1 shows average monthly and annual temperatures $\left({ }^{\circ} \mathrm{C}\right)$ for calendar year 1988 for selected Hanford telemetry network stations closest to the proposed NPR site (plus the HMS). Calendar year 1988 was the first year in which a complete annual record was available, and because this data set covers only one calendar year, no significant conclusions regarding temperature differences and distributions can be drawn.

Relative humidity and dewpoint temperature are measured at the HM and' at the three $60-\mathrm{m}$ tower locations. The annual average relative humidity at the $\mathrm{HM}$ is 54\%. It is highest during the winter months, averaging about $75 \%$, and lowest during the summer, averaging about 35\%. Wetbulb temperatures greater than $24^{\circ} \mathrm{C}$ had not been observed at the $\mathrm{HS}$ prior to 1975; however, on July 8, 9, and 10 of that year, there were seven hourly observations with wetbulb temperatures greater than or equal to $24^{\circ} \mathrm{C}$.

TABLE 2.1. Average Monthly and Annual Temperatures $\left({ }^{\circ} \mathrm{C}\right)$ for Selected Hanford Telemetry Network Stations

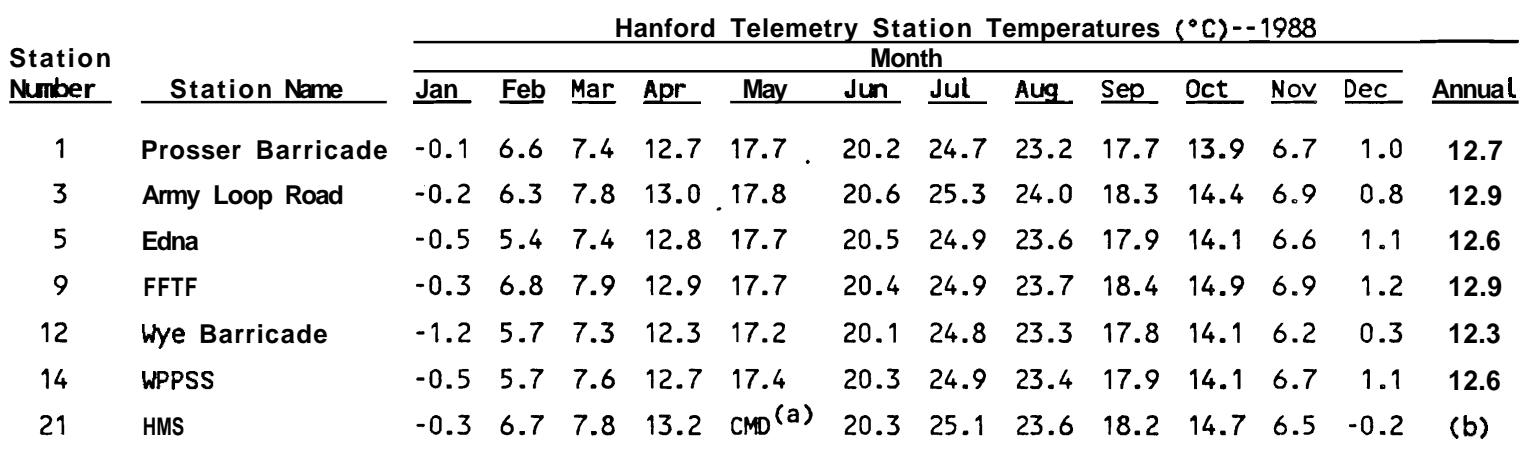

(a) CMD - Considerable missing data.

(b) Incomplete record due to missing data. 


\subsection{PRECIPITATION}

Precipitation measurements have been made at the HMS since 1945. Average annual precipitation at the HMS is $16 \mathrm{~cm}$. Most of the precipitation occurs during the winter with nearly half of the annual amount occurring in the months of November through February. Days with greater than 0.5 in. $(1.3 \mathrm{~cm})$ precipitation occur less than $1 \%$ of the year. Rainfall intensities of $0.5 \mathrm{in.}(1.3 \mathrm{~cm} / \mathrm{h})$ persisting for 1 hour are expected once every 10 years. Rainfall intensities of $1 \mathrm{in}$. $(2.5 \mathrm{~cm} / \mathrm{h})$ for 1 hour are expected once every 500 years. Winter monthly average snowfall ranges from $0.8 \mathrm{~m}$ in March to $13.5 \mathrm{~m}$ in January. The record snowfall of $62 \mathrm{am}$ occurred in February 1916. Snowfall accounts for about $\mathbf{3 8 \%}$ of all precipitation during the months of December through February.

In the spring of 1987, precipitation measurements for four other locations (Rattlesnake Mountain, Richland Airport, Rattlesnake Springs, and Yakima Barricade) were added to the meteorological measurement system. Precipitation measurements have also been made on the Arid Lands Ecology Reserve on the western slope of the Rattlesnake Hills (Stone et al. 1983).

\section{$2.4 \quad$ FOG AND VISIBILITY}

Fog has been recorded during every month of the year at the HMS; however, 95\% of the occurrences are during the months of November through February, with less than $1 \%$ during the months of April through September (Table 2.2). The average number of days per year with fog (visibility less than or equal to $9.6 \mathrm{~km}$ ) is 45 days, and with dense fog (visibility less than or equal to $0.4 \mathrm{~km}) 24$ days. The greatest number of days with fog was 84 days in 1985-86, and the least 22 in 1948-49; while the greatest number of days with dense fog was 42 days in 1950-51, and the least 9 days in 1948-49.

TABLE 2.2. Number of Days with Fog by Season

\begin{tabular}{|c|c|c|c|c|c|}
\hline Cateqory & $\underline{\text { Winter }}$ & $\underline{\text { Spring }}$ & $\underline{\text { Summer }}$ & $\underline{\text { Autumn }}$ & Total \\
\hline Fog & 31 & 2 & $\leq 1 / 2$ & 12 & 45 \\
\hline Dense Fog & 17 & 1 & $\leq 1 / 2$ & 6 & 24 \\
\hline
\end{tabular}


The greatest persistence of fog was 114 hours (December 1985), and the greatest persistence of dense fog was 47 hours (December 1957).

Other phenomena causing restrictions to visibility (i.e., visibility less than or equal to $9.6 \mathrm{~km}$ ) include dust, blowing dust, and smoke. The number of such days is small, with an average of 5 days per year resulting from dust or blowing dust, and less than 1 day per year resulting from smoke.

\subsection{SEVERE WEATHER}

High winds are also associated with thunderstorms. The average occurrence of thunderstorms is 10 per year. They are most frequent during the summer; however, they have occurred in each month. The average winds during thunderstorms do not come from any specific direction. Estimates of the extreme winds, based on peak gusts observed from 1945 through 1980, are given in Stone et al. (1983) and are shown in Table 2.3. Using the National Weather Service criteria for classifying a thunderstorm as "severe, " (i.e., hail with a diameter equal to or greater than $20 \mathrm{~mm}$ or wind gusts of $93 \mathrm{~km} / \mathrm{h}$ or greater) only $1.9 \%$ of all thunderstorm events observed at the HWS have been "severe" storms, and all met the criteria based upon wind gusts.

Tornados are infrequent and generally small in the northwest portion of the United States. Grazulis (1984) lists no violent tornados for the region surrounding Hanford (DOE 1986). The HS climatological summary (Stone et al. 1983) and the National Severe Storms Forecast Center (NSSFC) database 1ist 22 separate tornado occurrences within $161 \mathrm{~km}$ of the Hanford Site from 1916 through August 1982. Two additional tornados have been reported since August 1982.

TABLE 2.3. Estimates of Extreme Winds at Hanford Site

\begin{tabular}{cccc}
$\begin{array}{c}\text { Return } \\
\text { Period, yr }\end{array}$ & & $\begin{array}{c}\text { Peak Gusts. } \mathrm{km} / \mathrm{h} \\
\text { Above Ground }\end{array}$ & $\begin{array}{c}61 \mathrm{~m} \\
\text { Above Ground }\end{array}$ \\
\cline { 4 - 4 } 12 & & 97 & 109 \\
10 & & 114 & 129 \\
100 & & 137 & 151 \\
1000 & & 159 & 175
\end{tabular}


Using the information in the preceding paragraph and the statistics published in Ramsde11 and Andrews (1986) for the $5^{\circ}$ block centered at $117.5^{\circ}$ west longitude and 47.5" north latitude (the area in which the Hanford Site is located), the expected path length of a tornado on the Hanford Site is $7.6 \mathrm{~km}$, the expected width is $95 \mathrm{~m}$, and the expected area is about $1.5 \mathrm{~km}^{2}$. Also from Ramsde11 and Andrews (1986), the estimated probability of a tornado striking a point at Hanford is $9.6 \times 10^{-6} / \mathrm{yr}$. The probabilities of extreme winds associated with tornadoes striking a point can be estimated using the distribution of tornado intensities for the region. These probability estimates are given in Table 2.4 .

\subsection{ATMOSPHERIC DISPERSION}

Atmospheric dispersion is a function of wind speed, atmospheric stability, and mixing depth. Dispersion conditions are generally good if winds are moderate to strong, if the atmosphere is of neutral or unstable stratification, and if there is a deep mixing layer. Good dispersion conditions associated with neutral and unstable stratification exist about $57 \%$ of the time during the summer. Less favorable dispersion conditions may occur when the wind speed is light and the mixing layer is shallow. These conditions are most common during the winter when moderately to extremely stable stratification exists about $66 \%$ of the time. Less favorable conditions also occur periodically for surface and low-level releases in all seasons from about sunset to about an hour after sunrise as a result of ground-based temperature inversions and shallow mixing layers. Mixing-layer thicknesses have been

\begin{tabular}{|c|c|c|}
\hline TABLE 2.4. & $\begin{array}{l}\text { Estimate of th } \\
\text { Associated witl } \\
\text { Hanford (Ramsc }\end{array}$ & $\begin{array}{l}\text { obability of Extreme Winds } \\
\text { rnados Striking a Point at } \\
\text { and Andrews 1986) }\end{array}$ \\
\hline & $\begin{array}{c}\text { Wind Speed, } \\
\mathrm{km} / \mathrm{h}\end{array}$ & $\begin{array}{l}\text { Probabi 1ity } \\
\text { Per Year }\end{array}$ \\
\hline & 100 & $2.6 \times 10^{-6}$ \\
\hline & 200 & $6.5 \times 10^{-7}$ \\
\hline & 300 & $1.6 \times 10^{-7}$ \\
\hline & 400 & $3.9 \times 10^{-8}$ \\
\hline
\end{tabular}


estimated at the HNS using remote sensors. The variations in mixing-layer described previously are summarized in Table 2.5 .

Occasionally there are extended periods of poor dispersion conditions that are associated with stagnant air in stationary high-pressure systems that occur primarily during the winter months. Stone et al. (1972) estimated the probability of extended periods of poor dispersion conditions. The probability of an inversion period extending more than 12 hours varies from a low of about $10 \%$ in May and June to a high of about $64 \%$ in September and October. These probabilities decrease rapidly for durations of greater than 12 hours. Table 2.6 summarizes the probabilities associated with extended surfacebased inversions.

Annual average atmospheric dispersion factors $\left(X / Q^{\prime}\right)$ have been computed for potential NPR facilities at the Skagit/Hanford site, the 200-E Area, and the 400 Area using 1983 through 1987 meteorological data. These diffusion factors are presented in Tables 2.7 through 2.10 as a function of direction

TABLE 2.5. Percent Frequency of Occurrence of Mixing-Layer Thickness by Season and Time of Day

\begin{tabular}{|c|c|c|c|c|}
\hline \multirow[b]{2}{*}{ Mixing Laver, $\mathrm{m}$} & \multicolumn{2}{|c|}{ Winter } & \multicolumn{2}{|c|}{ Summer } \\
\hline & Niqht & Day & Niaht & Day \\
\hline Less than 250 & 65.7 & 35.0 & 48.5 & 1.2 \\
\hline $250-500$ & 24.7 & 39.8 & 37.1 & 9.0 \\
\hline More than 500 & 9.6 & 25.2 & 14.4 & 89.9 \\
\hline
\end{tabular}

TABLE 2.6. Percent Probabilities for Extended Periods of Surface-Based Inversions

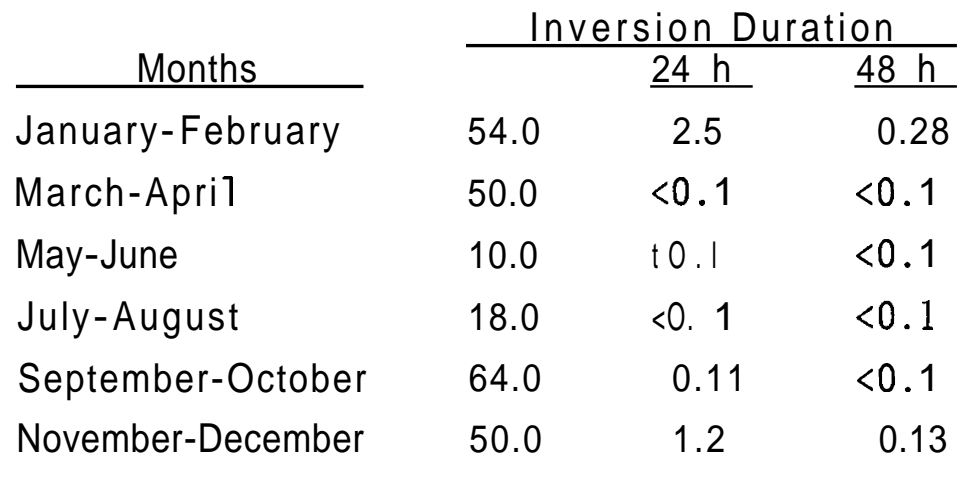


TABLE 2.7. Annual Average Atmospheric Dispersion Factors $\left(X / Q^{\prime}\right)$ for the Skagit-Hanford Site for Ground-Level Releases Based on 1983-1987 Data

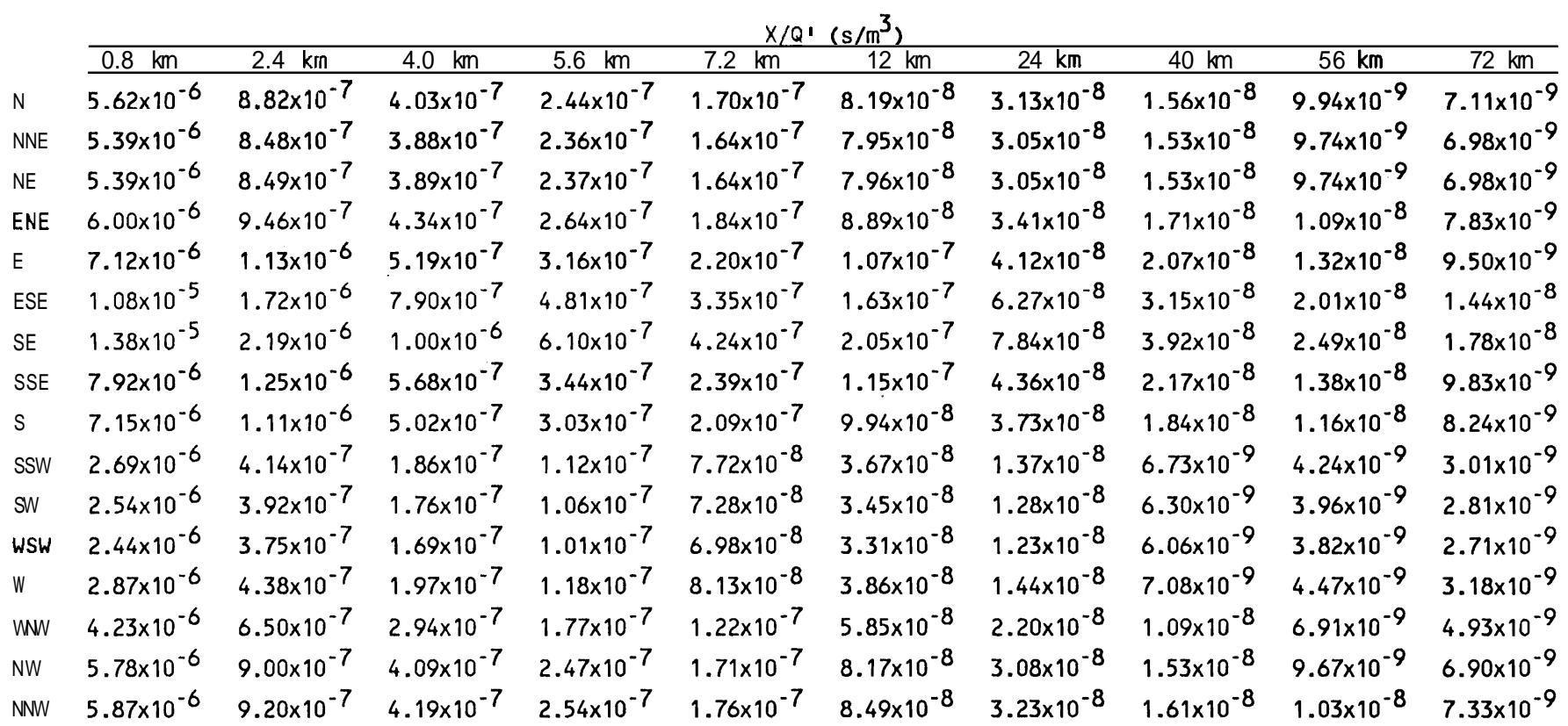


TABLE 2.8. Annual Average Atmospheric Dispersion Factors $\left(X / Q^{\prime}\right)$ for the 200-E Area for an 89-Meter Release Based on 1983-1987 Data

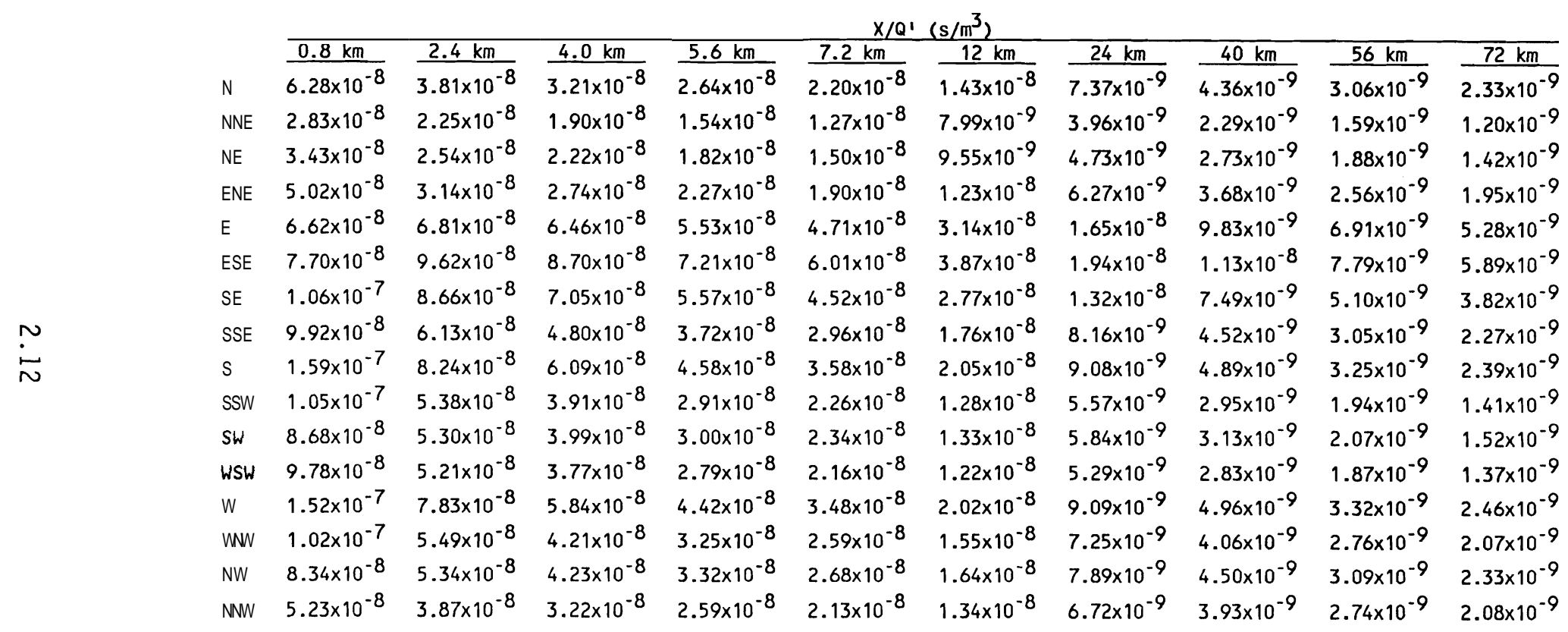


TABLE 2.9. Annual Average Atmospheric Dispersion Factors ( $\left.X / Q^{\prime}\right)$ for the 200-E Area for a Ground-Level Release Based on 1983-1987 Data

\begin{tabular}{|c|c|c|c|c|c|c|c|c|c|c|}
\hline & & & & & & & & & & \\
\hline & $8 \mathrm{~km}$ & $2.4 \mathrm{~km}$ & $4.0 \mathrm{~km}$ & $5.6 \mathrm{~km}$ & $7.2 \mathrm{~km}$ & $2 \mathrm{~km}$ & $24 \mathrm{~km}$ & $40 \mathrm{~km}$ & $56 \mathrm{~km}$ & 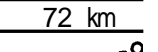 \\
\hline & $3.87 \times 10^{-6}$ & $6.08 \times 10^{-7}$ & $2.79 \times 10^{-7}$ & $1.70 \times 10^{-7}$ & $1.18 \times 10^{-7}$ & $5.72 \times 10^{-8}$ & $2.20 \times 10^{-8}$ & $1.10 \times 10^{-8}$ & $7.05 \times 10^{-9}$ & $5.06 \times 10$ \\
\hline NNE & $.04 \times 10^{-6}$ & $3.21 \times 10^{-7}$ & $1.47 \times 10^{-7}$ & $8.93 \times 10^{-8}$ & $6.20 \times 10^{-8}$ & $3.00 \times 10^{-8}$ & $1.15 \times 10^{-8}$ & $5.75 \times 10^{-9}$ & $3.67 \times 10^{-9}$ & $2.63 \times 10^{-9}$ \\
\hline NE & $43 \times 10^{-6}$ & $3.83 x$ & $1.75 \times 10^{-7}$ & $1.06 \times 10^{-7}$ & $7.39 \times 10^{-8}$ & & $1.37 x$ & $6.84 \times 10^{-9}$ & & \\
\hline ENE & $30 \times 10^{-6}$ & $18 \times 10^{-7}$ & $2.37 \times 1$ & $10^{-7}$ & $.00 \times 10^{-7}$ & $\times 10^{-8}$ & -8 & $9.33 \times 10^{-9}$ & -9 & $10^{-9}$ \\
\hline & $99 \times 10^{-6}$ & $.42 \times 10^{-6}$ & $6.54 \times 10^{-7}$ & $3.99 \times 10^{-7}$ & $2.77 \times 10^{-7}$ & $1.35 \times 10^{-7}$ & $5.19 \times 10^{-8}$ & $2.60 \times 10^{-8}$ & $1.66 \times 10^{-8}$ & $.19 \times 10^{-8}$ \\
\hline ESE & $.59 \times 10^{-6}$ & $1.52 \times 10^{-6}$ & $6.94 \times 10^{-7}$ & $4.22 \times 10^{-7}$ & $2.93 \times 10^{-7}$ & $1.41 \times 10^{-7}$ & $5.40 \times 10^{-8}$ & $2.69 \times 10^{-8}$ & $1.71 \times 10^{-8}$ & $1.23 \times 10^{-8}$ \\
\hline SE & $34 \times 10^{-6}$ & $9.93 \times 10^{-7}$ & $4.52 \times 10^{-7}$ & $2.73 \times 10^{-7}$ & $1.89 \times 10^{-7}$ & $9.08 \times 10^{-8}$ & $3.44 \times 10^{-8}$ & $1.71 \times 10^{-8}$ & $1.08 \times 10^{-8}$ & $7.74 \times 10^{-9}$ \\
\hline SSE & $91 \times 10^{-6}$ & $07 \times 10^{-7}$ & $75 \times 10^{-7}$ & $1.66 \times 10^{-7}$ & $1.15 \times 10^{-7}$ & $5.50 \times 10^{-8}$ & $2.08 \times 10^{-8}$ & $1.03 \times 10^{-8}$ & $6.51 \times 10^{-9}$ & $4.64 \times 10^{-9}$ \\
\hline s & $24 \times 10^{-6}$ & $6.51 \times 10^{-7}$ & $2.93 \times 10^{-7}$ & $1.76 \times 10^{-7}$ & $1.21 \times 10^{-7}$ & $5.75 \times 10^{-8}$ & $2.14 \times 10^{-8}$ & $1.05 \times 10^{-8}$ & $6.63 \times 10^{-9}$ & $4.71 \times 10$ \\
\hline SSW & $2.53 \times 10^{-6}$ & $3.87 \times 10^{-7}$ & $1.73 \times 10^{-7}$ & $1.04 \times 10^{-7}$ & $7.12 \times 10^{-8}$ & $3.36 \times 10^{-8}$ & $1.24 \times 10^{-8}$ & $6.06 \times 10^{-9}$ & $3.80 \times 10^{-9}$ & $\times 10$ \\
\hline SW & $98 \times 10^{-6}$ & $4.61 \times 10^{-}$ & & 1.2 & $8.57 \times 10^{-8}$ & $0^{-8}$ & -8 & & & \\
\hline WS & $60 \times 10^{-6}$ & $3.99 \times 10^{-7}$ & $1.79 \times 10^{-7}$ & $1.07 \times 10^{-7}$ & $7.39 \times 10^{-8}$ & $3.50 \times 10^{-8}$ & $1.30 \times 10^{-8}$ & $6.37 \times 10^{-9}$ & $4.01 \times 10^{-9}$ & $2.84 \times 10^{-9}$ \\
\hline & $45 \times 10^{-6}$ & $6.86 \times 10^{-7}$ & $3.10 \times 10^{-7}$ & $1.87 \times 10^{-7}$ & $1.29 \times 10^{-7}$ & $6.15 \times 10^{-8}$ & $2.31 \times 10^{-8}$ & $1.14 \times 10^{-8}$ & $7.22 \times 10^{-9}$ & $5.14 \times 10^{-9}$ \\
\hline Ww & $.65 \times 10^{-6}$ & $5.66 \times 10^{-7}$ & $.57 \times 10^{-7}$ & $1.55 \times 10^{-7}$ & $1.07 \times 10^{-7}$ & $5 \times 10^{-8}$ & $1.95 \times 10^{-8}$ & $9.67 \times 10^{-9}$ & $6.14 \times 10^{-9}$ & $4.38 \times 10^{-9}$ \\
\hline NW & $3.67 \times 10^{-6}$ & -7 & $10^{-7}$ & $1.58 \times 10^{-7}$ & $1.09 \times 10^{-7}$ & $5.26 \times 10^{-8}$ & $2.00 \times 10^{-8}$ & $9.97 \times 10^{-9}$ & $6.34 \times 10^{-9}$ & $4.53 \times 10^{-9}$ \\
\hline NNW & $.56 \times 10^{-6}$ & $.60 \times 10^{-7}$ & $.56 \times 10^{-7}$ & $.56 \times 10^{-7}$ & $.08 \times 10^{-7}$ & $5.24 \times 10^{-8}$ & $2.01 \times 10^{-8}$ & $1.00 \times 10^{-8}$ & $6.40 \times 10^{-9}$ & $4.59 \times 10^{-}$ \\
\hline
\end{tabular}


TABLE 2.10. Annual Average Atmospheric Dispersion Factors $\left(X / Q^{\prime}\right)$ for the 400 Area for a Ground-Level Release Based on 1983-1987 Data

\begin{tabular}{|c|c|c|c|c|c|c|c|c|c|c|}
\hline & & & & & & & & & & \\
\hline & $0.8 \mathrm{~km}$ & - & 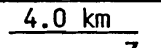 & 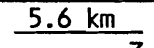 & $7.2 \mathrm{~km}$ & $=$ & & $40 \mathrm{~km}$ & $56 \mathrm{~km}$ & $72 \mathrm{~km}$ \\
\hline & $7.73 x$ & $21 x$ & $5.55 \times 1$ & $37 x$ & $34 \times 10^{-}$ & $.13 \times 1$ & 4.31 & $2.15 \times 10^{-8}$ & 1.37 & $.81 \times 10^{-}$ \\
\hline NNE & & & & & & & & & & \\
\hline $\mathrm{E}$ & & & & & -7 & & & & & \\
\hline NE & & & & & -8 & & & & & \\
\hline & & & $2.60 \times 10^{-7}$ & 1.58 & $09 \times 10^{-7}$ & & 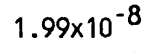 & $87 \times 10^{-9}$ & 6.26 & \\
\hline SE & & & & & & & & & & \\
\hline E & & & & & -7 & & & & & \\
\hline SE & & & & & & & & & & \\
\hline & & & & & & & & & & \\
\hline & & & & & $9.67 x$ & .66 & - & -9 & & \\
\hline & & 3 & -7 & 8 & $6.86 \times 10^{-8}$ & -8 & -8 & -9 & & \\
\hline & & 2 & 7 & 7.28 & $.03 \times 10^{-8}$ & -8 & -9 & & & 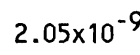 \\
\hline & & 76 & $1.71 \times 10^{-7}$ & 1.03 & $7.14 \times 10^{-8}$ & $0^{-8}$ & & -9 & & $.94 \times 10^{-}$ \\
\hline & 2.24 & $47 x$ & $1.57 \times 10^{-7}$ & $9.47 x$ & $6.54 \times 10^{-8}$ & $13 \times 10^{-8}$ & -8 & $0^{-9}$ & -9 & $.63 \times 10^{-9}$ \\
\hline & & & -7 & & $0^{-8}$ & $0^{-8}$ & & & & \\
\hline & $10^{\circ}$ & 10 & $100^{\circ}$ & ) & -7 & $.57 \times 10^{-8}$ & 8 & $0^{-8}$ & -9 & $.08 x$ \\
\hline
\end{tabular}


and distance from the facility. Table 2.7 for the Skagit/Hanford site and Table 2.10 for the 400-Area are for ground-level releases. For the 200-E area, diffusion factor tables are presented for both elevated (Table 2.8) and ground-level (Table 2.9) releases. An effective stack height of $89 \mathrm{~m}$ has been assumed for elevated releases in Table 2.8, based on an actual stack height of $61 \mathrm{~m}$ and a typical plume rise of $28 \mathrm{~m}$.

\subsection{AIR QUALITY}

National ambient air quality standards (NAAQS) have been set by the U.S. Environmental Protection Agency (EPA), as mandated in the 1970 Clean Air Act. "Ambient air" is defined in the U.S. Code of Federal Regulations (1985) as "that portion of the atmosphere, external to buildings, to which the general public has access." The standards define levels of air quality that are necessary, with adequate margin of safety, to protect the public health (primary standards) and the public welfare (secondary standards). Standards exist for sulfur oxides (measured as sulfur dioxide), nitrogen dioxłde, carbon monoxide, total suspended particulates (TSP), lead, and ozone. ${ }^{\text {The standards }}$ specify the maximum pollutant concentrations and frequencies of occurrence that are allowed for specific averaging periods (e.g., the concentration of carbon monoxide when averaged over 1 hour is allowed to exceed $40 \mathrm{mg} / \mathrm{m}^{3}$ only once per year). The averaging periods vary from 1 hour to 1 year, depending on the pollutant.

In 1987, the EPA proposed a revision to the particulate standard to include only particles with an aerodynamic diameter less than or equal to a nominal 10 micrometers (PM-10). These standards became effective July 31 , 1987, replacing the TSP standards. In the interim, while states (including Washington) are developing Implementation Plans for PM-10, the TSP standards are still being enforced.

State and local governments have the authority to impose standards for ambient air quality that are stricter than the national standards. Washington State has established more stringent standards for sulfur dioxide and total

(a) Lead and ozone are not discussed in this report because significant concentrations of these pollutants will not result from NPR activities. 
suspended particulates. In addition, Washington State has establ ished standards for volatile organic compounds (VOC), arsenic, fluoride, and other pollutants that are not covered by national standards. The state standards for carbon monoxide and nitrogen dioxide are identical to the national standards. At the local level, the Tri-County (Benton, Franklin, and Walla Walla) Air Pollution Control Authority has the authority to tighten NAAQS in the vicinity of the Hanford Site, but has established no local standards.

Areas not in compliance with the NAAQS are termed "nonattainment" areas, while areas meeting the NAAQS are referred to as "attainment" areas. Areas with insufficient data to make a determination are unclassified, but are treated as attainment areas until proven otherwise. The designation of an area is made on a pollutant specific basis. Attainment (and unclassified) areas are subject to the Prevention of Significant Deterioration (PSD) regulations.

The PSD regulations require the owner or operator of a facility to obtain a permit before construction of a major new source or modification of an existing major source located in an attainment or unclassified area. A major new stationary source (as defined by PSD regulations) is any facility identified from a list of 28 specific categories that has the potential to emit more than 100 tonnes per year ( $t / y)$ of any of the pol lutants regulated by PSD. A facility is also considered a major source if it has the potential to emit more than $250 \mathrm{t} / \mathrm{y}$ of any of the regulated pollutants.

Sources are allowed to consume only part of the available increment for new emissions. For attainment areas, maximum allowable increases in ambient pollutant concentrations have been established for $\mathrm{SO}_{2}$ and TSP to prevent significant deterioration of the baseline air quality. PSD increments have not yet been established for PM-10, particles with an aerodynamic diameter less than or equal to a nominal $10 \mu \mathrm{m}$.

\subsubsection{Major Stationary Emission Sources}

Emission inventories for significant pollution sources in Benton, Franklin, and Walla Walla Counties are routinely compiled by the Tri-County Air Pollution Control Board. In 1987 (the most recent year available), there 
were 98 stationary sources identified within the Tri-County area. Of these, only eight sources exceeded $100 \mathrm{t} / \mathrm{y}$ for one or more of the criteria pollutants. The vast majority of the sources emitted less than $10 \mathrm{t} / \mathrm{y}$ of any of the criteria pollutants (see Table 2.11 below).

Table 2.12 lists those stationary sources within the Hanford Site boundaries that have been reported to the Washington State Department of Ecology (Ecology) by the DOE. Table 2.13 lists those major sources (emissions >100 $t / y$ ) within approximately $50 \mathrm{~km}$ of the proposed NPR site. The location of each of these sources is shown in Figure 2.4 .

\subsubsection{Backqround Concentrations}

Periodically during the past 10 years, carbon monoxide, sulfur dioxide, and nitrogen dioxide have been monitored in communities and commercial areas southeast of Hanford (NRC 1982). These urban measurements are typically used to estimate the maximum background pollutant concentrations for the Hanford Site because of the lack of specific onsite monitoring. Since these measurements were made in the vicinity of local sources of pollution, they will overestimate maximum background concentrations within the Hanford Site or at the site boundaries.

Particulate concentrations can reach relatively high levels in eastern Washington State because of exceptional natural events (i .e., dust storms, volcanic eruptions, and large brushfires) that periodically occur in the region. Washington state ambient air quality standards do not consider

TABLE 2.11. Frequency of Occurrence of Emission Rates for Sources Within or Near the Hanford Site

\begin{tabular}{|c|c|c|c|c|c|}
\hline \multirow{2}{*}{$\begin{array}{c}\text { Emission } \\
\text { Rate (t/y) }\end{array}$} & \multicolumn{5}{|c|}{ Criteria Pollutant } \\
\hline & Part. & ${ }^{\mathrm{S}} \mathrm{O}_{2}$ & ${ }^{N O} O_{X}$ & VOC & $\mathrm{CO}$ \\
\hline$<10$ & 78 & 90 & 84 & 88 & 95 \\
\hline $11-50$ & 10 & 3 & 3 & 5 & 2 \\
\hline $51-100$ & 6 & 2 & 3 & 1 & 1 \\
\hline $101-500$ & 4 & 1 & 8 & 3 & 0 \\
\hline $501-1000$ & 0 & 2 & 0 & 1 & 0 \\
\hline$>1000$ & 0 & 0 & 0 & 0 & 0 \\
\hline
\end{tabular}


TABLE 2.12. Emission Rates ( $t / y)$ for Stationary Eniission Sources Within the Hanford Site. (The numbers preceding the source description are keyed to the source numbers in Figure 4.5.)

Source

1. $100 \mathrm{~N}$ Boiler

2. 100N Boiler

3. 300 Area Boiler \#2

4. 300 Area Boiler \#3

5. 300 Area Boiler \#4

6. 300 Area Boiler \#5

7. 300 Area Boiler \#6

8. 300 Area Boiler

9. 200E Boiler

10. 200W Boiler

11. 1100 Area

12. 1100 Area

13. 200E and W Fugitive Coal Piles

14. Fugitive Emissions

15. Backup Boiler 200E

\begin{tabular}{|c|c|c|c|c|}
\hline Part. & $\mathrm{SO}_{2}^{\mathrm{C}}$ & $\begin{array}{l}a_{\mathrm{NO}} \\
\mathrm{NO}_{\mathrm{X}}\end{array}$ & $\frac{\mathrm{ant}}{\text { VOC }}$ & $\overline{C O}$ \\
\hline 63 & 840 & 180 & 3 & 15 \\
\hline 1 & 11 & 4 & 1 & 1 \\
\hline 1 & 17 & 4 & 0 & 1 \\
\hline 5 & 92 & 52 & 200 & 7 \\
\hline 1 & 9 & 3 & 0 & 1 \\
\hline 4 & 90 & 51 & 0 & 1 \\
\hline 0 & 0 & 0 & 1 & 0 \\
\hline 0 & 5 & 4 & 0 & 0 \\
\hline 220 & 830 & 470 & 31 & 62 \\
\hline 95 & 350 & 200 & 13 & 26 \\
\hline 1 & 3 & 5 & 1 & 0 \\
\hline 1 & 2 & 3 & 0 & 0 \\
\hline 66 & 0 & 0 & 0 & 0 \\
\hline 1 & 0 & 0 & 0 & 0 \\
\hline 1 & 2 & 3 & 0 & 0 \\
\hline
\end{tabular}

TABLE 2.13. Emission Rates ( $t / y$ ) for Major (>100 $t / y$ ) Stationary Sources Near the Hanford Site

Source

16. Ammonia Oxidation Plant

17. $\mathrm{HNO}_{3}$ Tail Gas

18. Acid Plant Tail Gas

19. Asphalt Batching

20. Acid Plant Tail Gas

21. Fuel Loadout

22. Gas and Diesel

23. Distillate Tank Farm

\begin{tabular}{|c|c|c|c|c|}
\hline & Cri & $a P_{0}$ & & \\
\hline$\overline{\text { Part. }}$ & $\mathrm{SO}_{2}$ & $\mathrm{NO}_{\mathrm{X}}$ & VOC & $\overline{\mathrm{CO}}$ \\
\hline 0 & 0 & 475 & 0 & 0 \\
\hline 0 & 0 & 335 & 0 & 0 \\
\hline 0 & 0 & 260 & 0 & 0 \\
\hline 135 & 0 & 0 & 0 & 0 \\
\hline 0 & 0 & 109 & 0 & 0 \\
\hline 0 & 0 & 0 & 101 & 0 \\
\hline 0 & 0 & 0 & 505 & 0 \\
\hline 0 & 0 & 0 & 370 & 0 \\
\hline
\end{tabular}




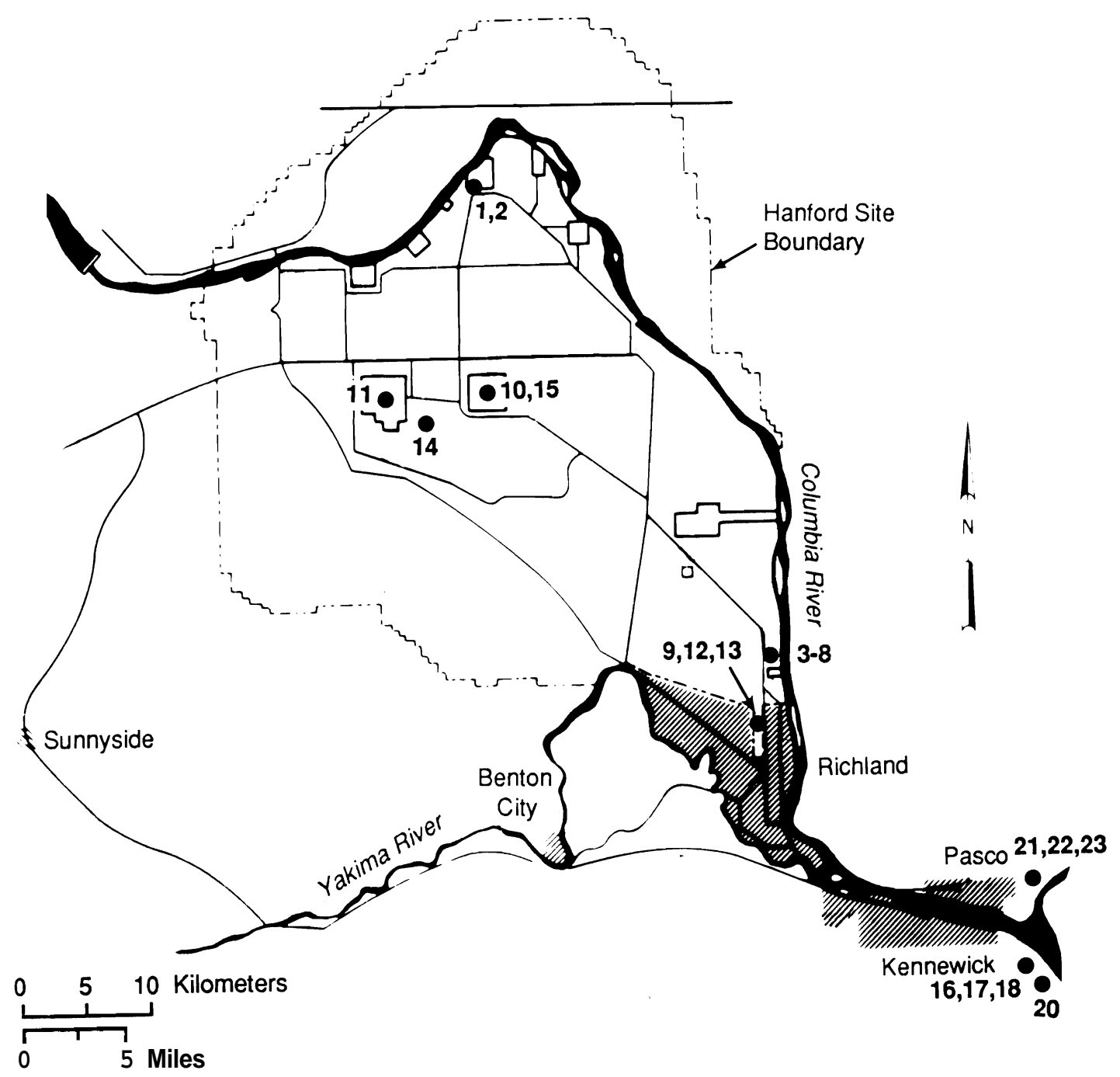

FIGURE 2.4. Major Stationary Emission Sources Within and Near the Hanford Site (see Tables 4.12 and 4.13 for source identification and emission rates)

"rural fugitive dust" from exceptional natural events when estimating the maximum background concentrations of particulates in the area east of the Cascade Mountain crest. Similarly, the EPA also exempts the rural fugitive dust component of background concentrations when considering permit applications and enforcement of air quality standards.

Currently, only background concentrations of TSPs and nitrogen dioxide are monitored at the Hanford Site. Monitoring of TSPs was discontinued in 1988 when the Basalt Waste Isolation Project, for which those measurements 
were required, was stopped. Total suspended particulates are monitored at four locations near the Hanford Site by Ecology. The locations of the sampling stations are shown in Figure 2.5.

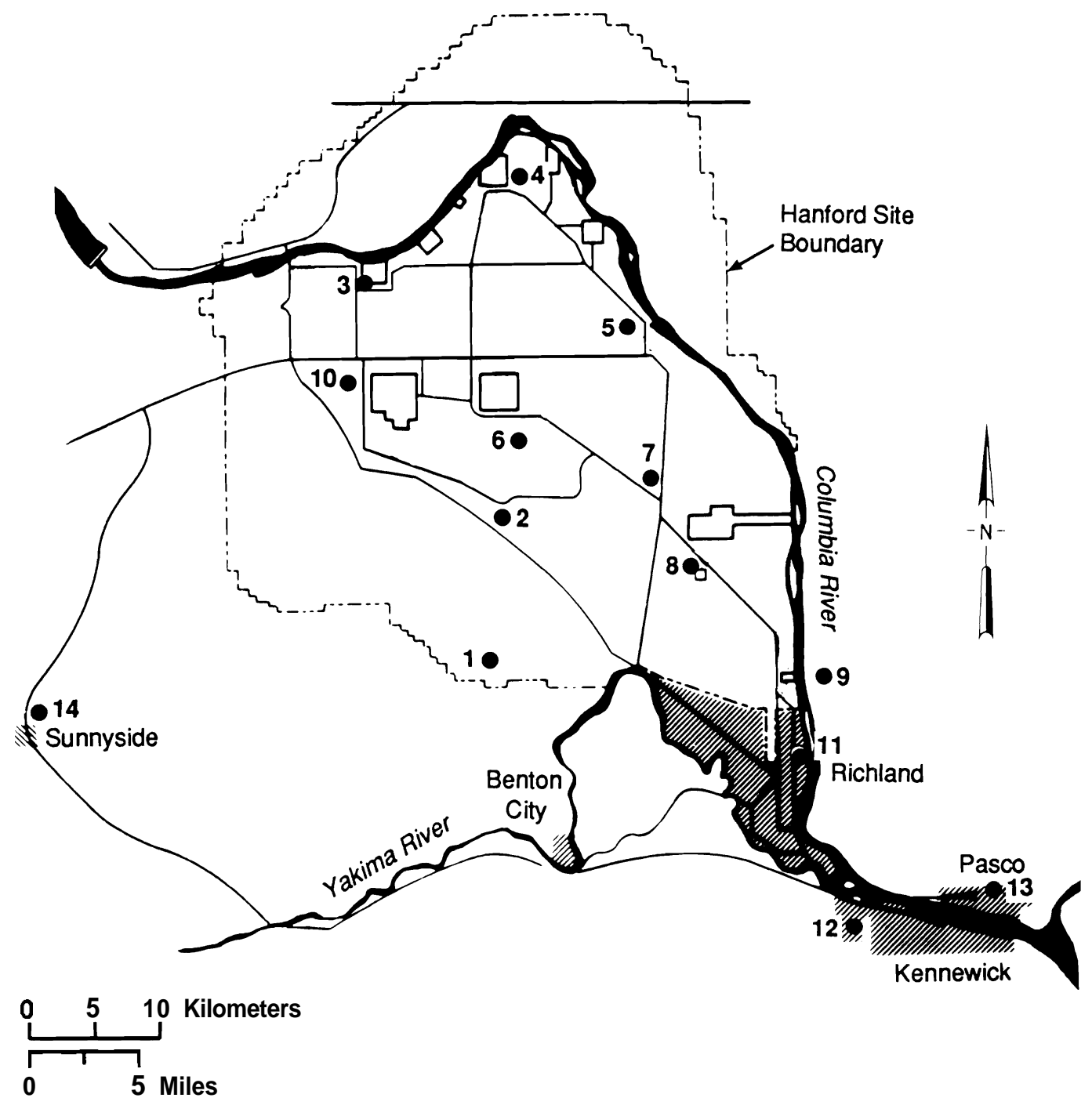

KEY

Sites 1-9: $\quad \mathrm{NO}_{2}$ monitoring

Site 10: $\quad$ TSP monitoring

Sites 11,13,14: TSP monitoring by Ecology

Site 12: $\quad$ TSP and PM-10 monitoring by Ecology

FIGURE 2.5. Ambient Air Monitoring Stations on the Hanford Site in 1987 
In 1987, $\mathrm{NO}_{2}$ was monitored at nine locations within or near the Hanford Site. Background concentrations at all locations were well below the applicable federal and Washington State annual ambient standard for $\mathrm{NO}_{2}$ $\left(100 \mu \mathrm{g} / \mathrm{m}^{3}\right)$. The highest annual average was $<16 \mu \mathrm{g} / \mathrm{m}^{3}$, which was measured at the Wye Barricade and the 100-D sampling locations.

Total suspended particulates were sampled near the ZOO-West Area beginning in 1986. In 1987, the annual geometric mean was $33 \mu \mathrm{g} / \mathrm{m}^{3}$ and the maximum 24-h value was $91 \mu \mathrm{g} / \mathrm{m}^{3}$, both well below the federal and state standards.

Total suspended particulates were monitored by Ecology at four locations near the Hanford Site. PM-10 was monitored at one location. The results are shown in Table 2.14.

Table 2.15 summarizes the pertinent NAAQS (federal and supplemental state standards) and the maximum background concentrations that have been measured in the vicinity of the Hanford Site. TABLE 2.14. Results of Particulate $\left(\mu \mathrm{g} / \mathrm{m}^{3}\right)$ Monitoring Near Hanford Site
in $1987(\mathrm{a})$

\section{Location}

TSP

Hanford Site

Kennewick, Columbia Center

Richland, Pumping Station

Pasco, County Courthouse

Sunnyside, Intermediate School

PM-10

Kennewick, Columbia Center
Annual Maximm

Geographic Concen-

$\underline{\text { tration }}$

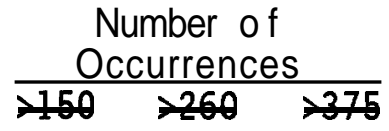

(a) SOURCE: "Washington State A ir Monitoring Data for 1987," Department of Ecology, Olympia, Washington. 
TABLE 2.15. Ambient Air Quality Standards and Maximum Measured Background Concentrations of Significant Pollutants at the Hanford Site $\left(\mu \mathrm{g} / \mathrm{m}^{3}\right)$

\begin{tabular}{|c|c|c|c|c|}
\hline Pollutant & $\begin{array}{l}\text { National } \\
\text { Primary } \\
\text { Standard }\end{array}$ & $\begin{array}{l}\text { National } \\
\text { Secondary } \\
\text { Standard }\end{array}$ & $\begin{array}{l}\text { Supp. } \\
\text { State } \\
\text { Standard }\end{array}$ & $\begin{array}{l}\text { Maximum } \\
\text { Background } \\
\text { Concentration }\end{array}$ \\
\hline $\begin{array}{l}\text { Nitrogen Dioxide }\left(\mathrm{NO}_{2}\right) \\
\text { Annual arithmetic mean }\end{array}$ & 100 & 100 & -- & 36 \\
\hline $\begin{array}{l}\text { Sulfur Dioxide }\left(\mathrm{SO}_{2}\right) \\
\text { Annual arithmetic mean } \\
24-h \text { maximum(a) } \\
\text { 3-h maximum (a) } \\
1-h \text { maximum (a) } \\
1-h \text { maximum (b) }\end{array}$ & $\begin{array}{r}80 \\
365 \\
-- \\
-- \\
--\end{array}$ & $\begin{array}{r}80 \\
365 \\
1,300 \\
-- \\
--\end{array}$ & $\begin{array}{r}52 \\
260 \\
-- \\
1,018 \\
655\end{array}$ & $\begin{array}{l}0.5 \\
6 \\
20 \\
49 \\
49\end{array}$ \\
\hline $\begin{array}{l}\text { Carbon Monoxide (CO) } \\
8-h \text { maximum }(a) \\
1-h \text { maximum }\end{array}$ & $\begin{array}{l}10,000 \\
40,000\end{array}$ & $\begin{array}{l}10,000 \\
40,000\end{array}$ & $\begin{array}{l}-- \\
-\end{array}$ & $\begin{array}{r}6,500 \\
11,800\end{array}$ \\
\hline $\begin{array}{l}\text { Total Suspended Particulates (c) } \\
\text { Annual geometric mean } \\
24-h \text { maximum(a) }\end{array}$ & $\begin{array}{r}75 \\
260\end{array}$ & $\begin{array}{r}60 \\
150\end{array}$ & $\begin{array}{r}40(d) \\
120(d)\end{array}$ & $\begin{array}{r}56 \\
356\end{array}$ \\
\hline
\end{tabular}

(a) Not to be exceeded more than once per year.

(b) Not to be exceeded more than two times in any consecutive 7 days.

(c) If the annual b 3 ckground concentration in eastern Washington State exceeds $20 \mu \mathrm{g} / \mathrm{m}^{3}$ or the $24-\mathrm{h}$ background concentrations exceeds $30 \mu \mathrm{g} / \mathrm{m}^{3}$ due to high levels of rural fugitive dust, the primary and secondary AAQS are replaced by a State standard that specifies the maximum allowable pollutant concentration independent of the background concentration of that pollutant.

(d) Plus background. 


\subsection{GEOLOGY}

This section describes the regional and local geology of the Hanford Site.

\subsection{GEOLOGIC SETTING OF THE HANFORD SITE}

The following material describes the regional geologic setting of the Pacific Northwest that contains the Hanford Site.

\subsubsection{Reqional Geologic Setting}

The region of the Pacific Northwest that contains the Hanford Site lies within the Columbia Intermontane physiographic province, which is bordered on the north and east by the Rocky Mountains and on the west by the Cascade Range (Figure 3.1). This province has been a topographic and structural depression since the early Miocene, and is subdivided into smaller physiographic units based primarily on topography and structural geologic history. The dominant geologic characteristics of the Columbia Intermontane Province have resulted from flood basalt volcanism. Flows of the Columbia River Basalt Group were extruded from linear vents in southeastern Washington, northeastern Oregon, and west-central Idaho between about 17 and 6 million years before the present time (mybp). The ancient basalt surface has subsequently been modified by tectonism, volcanism, weathering, and erosion.

The Columbia Intermontane Province is distinguished primarily by its relatively uniform rock type and undeformed nature with respect to adjacent provinces that developed under different tectonic and climatic settings. Within the Columbia Intermontane Province, the term Columbia Plateau is used informally to designate the area that is covered by the Columbia River Basalt Group.

The Columbia Intermontane Province is divided into four subprovinces. The Hanford Site is located within one of these, the Columbia Basin subprovince, which contains most of the Columbia River Basalt Group. This subprovince is bounded by the Cascade Range on the west, the northern Rocky Mountains on the north and east, and the Blue Mountains to the south. 


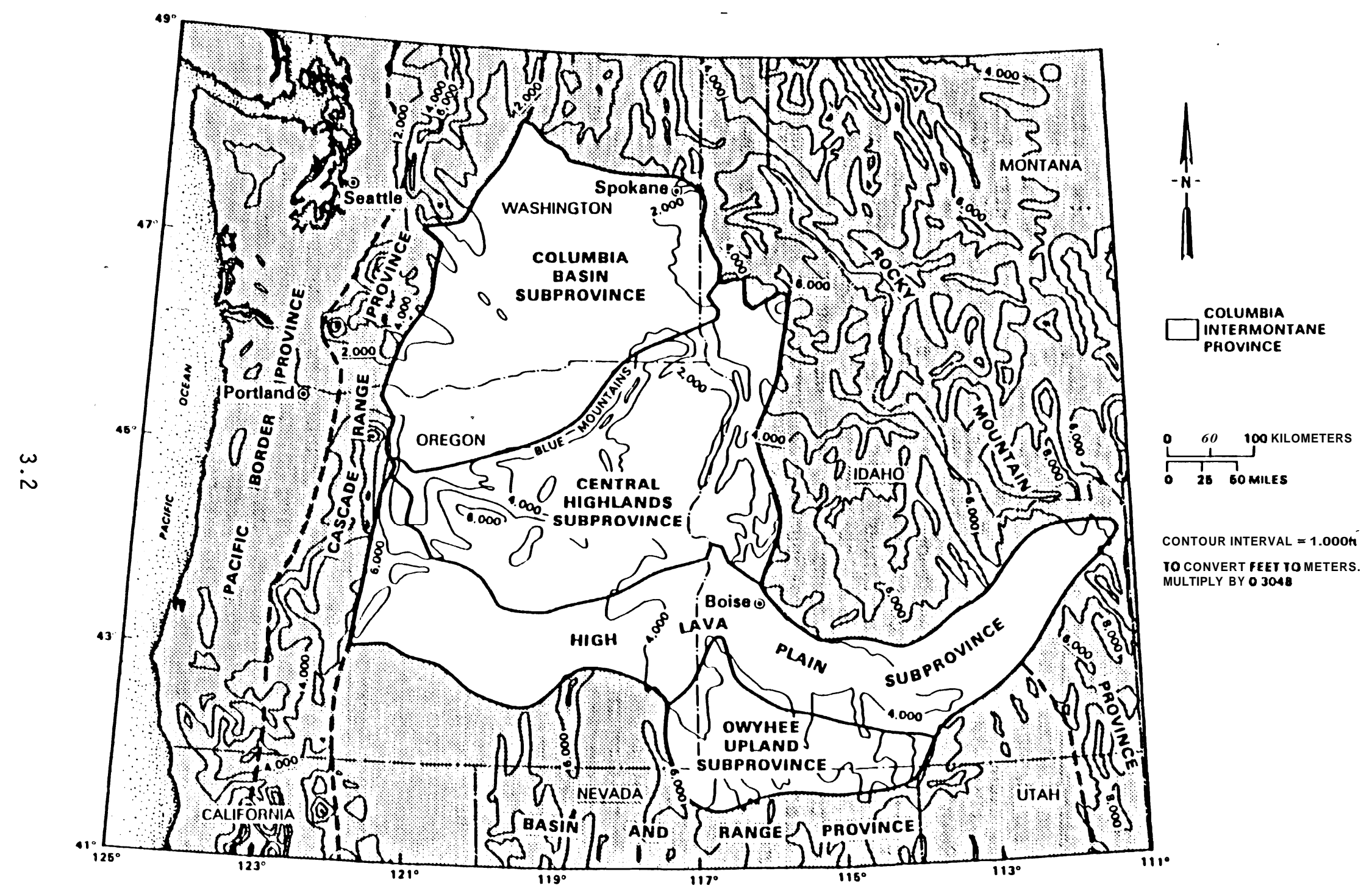

FIGURE 3.1. Divisions of the Columbia İñtermontane Province and Adjacent Provinces (DOE 1988) 
Mud of the Columbia Basin subprovince was affected by proglacial cataclysmic flooding associated with the sudden release of water from gl acial Lake Missoula. Cataclysmic floods have been responsible for mudh of the present morphology of the Channeled Scabland and Central Plains section. The number and timing of the proglacial flood events is not agreed upon, with estimates of the number of separate late-Pleistocene floods ranging from 2 to 40 (DOE 1988). Geological evidence suggests that glacial activity has been limited to the margins of the Columbia Basin subprovince. The maximum extent of the ice is defined by the well-developed Withrow Moraine, which lies approximately $110 \mathrm{~km}$ 'north of the Pasco Basin (DOE 1988).

Fluvial and lacustrine processes associated with the ancestral Col umbia River system, which includes the ancestral Snake and Yakima Rivers, have been active since the late Miocene. Deposits of these rivers and lakes are represented by the Ringold Formation and indicate that deposition was almost continuous from about 10.5 mybp until about 3.5 mybp (DOE 1988). Sometime prior to 900,000 years ago, a major change in regional base level resulted in fluvial incision of as much as $150 \mathrm{~m}$. The post-Ringold erosional surface was partially filled with locally derived alluvium prior to and/or between periods of Pleistocene flooding. However, in most areas of the Columbia Basin subprovince, the record of Pleistocene fluvial activity was destroyed by cataclysmic flooding.

Loess occurs in sheets that mantle much of the upland areas of the Columbia Basin subprovince.

The Columbia Plateau is tectonically a part of the North American continental plate, and is separated from the Pacific and Juan de Fuca oceanic plates to the west by the Cascade Range, the Puget-Wil lamette Lowland, and the Coast Range geologic provinces. It is bounded on the north by the Okanogan Highlands, on the east by the Northern Rocky Mountains and the Idaho Batholith, and on the south by the High Lava Plains and the Snake River Plain (Figure 3.2). The tectonic history of the Columbia Plateau has included the eruption of the continental flood basalts of the Columbia River Basalt Group during the period of about 17 to 6 mybp, as well as volcanic activity in the Cascade Range to the west (DOE 1988). 


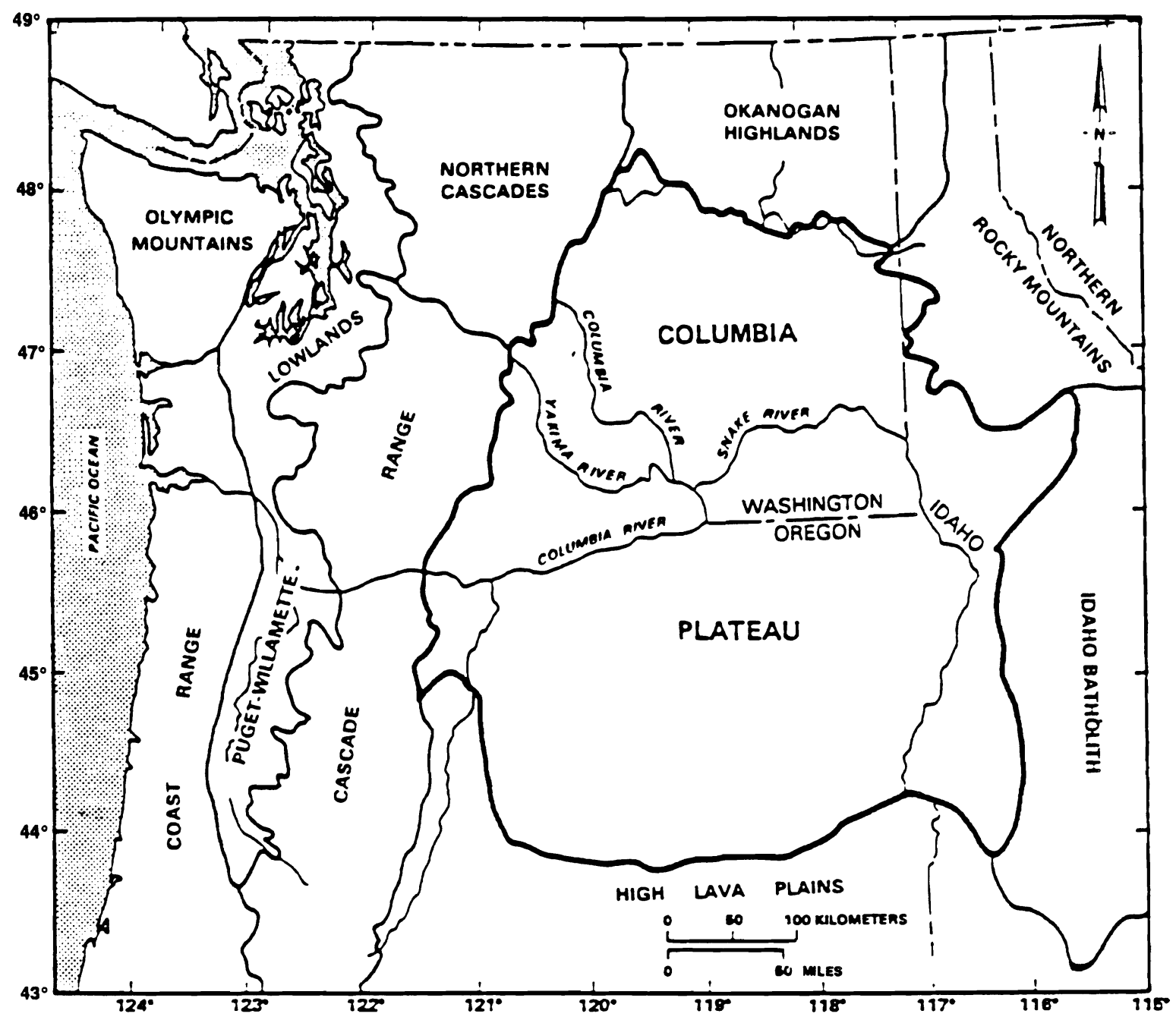

FIGURE 3.2. Index Mp of Geologic Provinces (DOE 1988)

\subsubsection{Local Geoloqic Setting}

The relatively low-relief, dry Columbia Basin subprovince is further divided into six physiographic sections (Figure 3.3). The Hanford Site is located in parts of two of these: the Yakima Folds and the Central Plains sections. The Yakima Folds section consists of east-west trending, asymmetrical anticlinal folds that plunge eastward where they merge with the lowrelief central plains section. The east-west trending folds have formed ridges that are believed to have developed because of north-south compression 


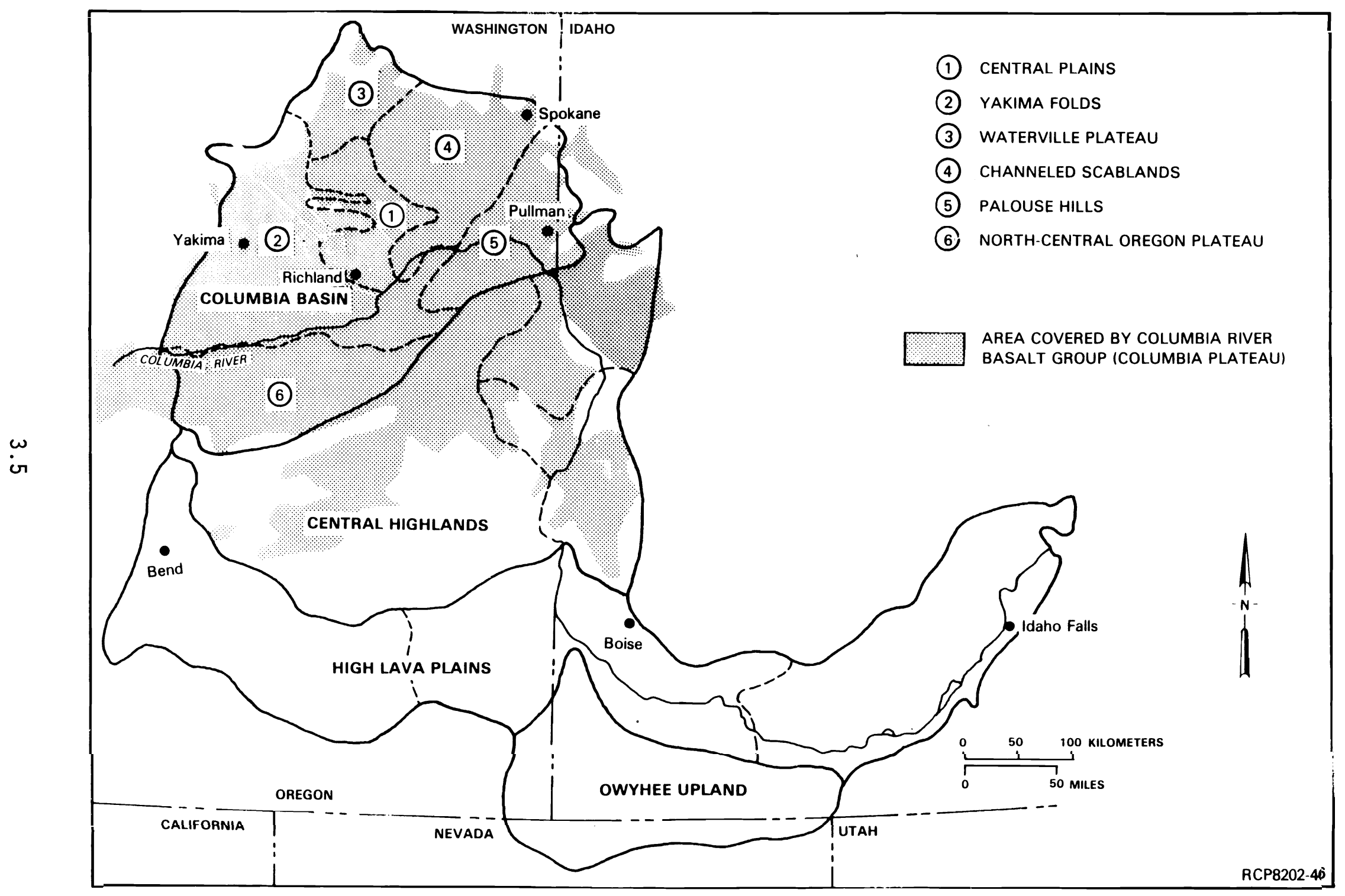

FIGURE 3.3. Divisions of the Columbia Intermontane Province (DOE 1986) 
and crustal shortening that has been active since the middle Miocene. The ridges have been undergoing degradation through weathering, mass wasting, and fluvial processes while the intervening synclinal valleys have aggraded intermittently with fluvial, proglacial, and eolian deposits since extrusion of the Columbia River Basalt. Average rates of uplift and subsidence on these folds are estimated at less than $40 \mathrm{~m} / \mathrm{mi11ion}$ years (DOE 1988).

The Central Plains section include the low-relief areas of the central Columbia Basin subprovince adjacent to and between the Yakima Folds. The Central Plains were significantly modified by erosion and deposition during the Pleistocene. The Central Plains section, as well as the rest of the Columbia Basin subprovince, have remained essentially unchanged since about 13,000 years ago except for minor fluvial and eolian activity.

Two major structural basins, the Quincy and the Pasco, are contained within the Central Plains section. The Hanford Site is located within the Pasco Basin. Loess deposits in the Pasco Basin are relatively thin (5 to $10 \mathrm{~m}$. Dune sand occurs in northeast-trending, longitudinal-shaped dunes in the south-central and eastern parts of the Pasco Basin. They reflect the predominantly southwest direction of strong winds across the basin.

The Hanford Site overlies the structural low point of the Pasco Basin near the confluence of the Yakima and Columbia Rivers. The boundaries of the Pasco Basin are defined by anticlinal structures of basaltic rock. These structures are the Saddle Mountains to the north; the Umtanum Ridge, Yakima Ridge, and Rattlesnake Hills to the west; and the Rattlesnake Hills and a series of doubly plunging anticlines merging with the Horse Heaven Hills to the south. The terrain within the Pasco Basin is relatively flat. Its surface features were formed by catastrophic floods and have undergone little modification since, with the exception of more recently formed sand dunes (DOE 1986).

\subsection{LITHOSTRATIGRAPHY OF THE HANFORD SITE}

The following sections contain descriptions of the lithology and stratigraphic relationships of the rock units in the Pasco Basin and at the Hanford Site. 


\subsubsection{Reqional Lithostratigraphv}

The major rock units of the Columbia Plateau are the subbasalt units (inferred to be sedimentary and volcanic1astic rocks), the Columbia River Basalt Group units, and the sedimentary rocks coincident with and overlying the basalts.

Knowledge of the subbasalt rocks is limited to studies of exposures along the margin of the Columbia Plateau and to a few deep boreholes drilled within the interior of the plateau (DOE 1988). No subbasalt rocks are exposed within the central interior of the Columbia. Plateau, including the Pasco Basin. Along the western margin of the plateau, the basalt flows lie on an irregular surface that resulted from erosion of a complex terrain of Mesozoic nietamorphics, Mesozoic to early-Tertiary sedimentaries, and earlyTertiary intrusive and volcanics. To the north, basalt is underlain by preCambrian metamorphic and sedimentary rocks, Paleozoic metasedimentary and volcaniclastic sedimentary rocks, Mesozoic marine lavas and sedimentary rocks, and Mesozoic to early-Tertiary granitic rocks. Basalt rests on preCambrian metasedimentary rocks and Mesozoic intrusive and volcanic rocks along the eastern margin of the plateau. To the south, basalt overlies Paleozoic sedimentary rocks, Mesozoic volcanic rocks, metamorphic and intrusive rocks, and early-Tertiary volcanic and sedimentary rocks.

Two of three deep boreholes drilled to the west of the Pasco Basin terminated in lower Tertiary sedimentary rocks similar to those exposed along the western margin of the plateau. Data from a fourth-hydrocarbonexploratory-well in the Saddle Mountains, just north of the Hanford Site, show that the well penetrated the basalt at about 3,500 $\mathrm{m}$ and bottomed in a sedimentary section at a total depth of about 5,350 m (DOE 1988).

The regional geology is dominated by the thick sequence of Miocene tholeitic continental flood basalts designated the Columbia River Basalt Group. This layered sequence, which erupted from north-northwest trending fissures or linear vent systems in northcentral and northeastern Oregon, eastern Washington, and western Idaho (DOE 1988), consists of about $170,000 \mathrm{~km}^{3}$ of basalt covering about $160,000 \mathrm{~km}^{2}$. Recent interpretations of existing data indicate that in most portions of the Pasco Basin the basalt is 
in excess of $3,000 \mathrm{~m}$ in thickness. Figure 3.4 shows the stratigraphic relationships and nomenclature for the Columbia River Basalt Group of the Col umbi a Plateau.

The Columbia River Basalt Group is formally divided into five formations (Ledgerwood e t a1. 1978; Swanson et a1. 1979). They are, from the oldest to the youngest: Imnaha Basalt, Picture Gorge Basalt, Grand Ronde Basalt, Wanapum Basalt, and Saddle Mountains Basalt. The Imnaha and Picture Gorge Basalts are not known to occur within the Pasco Basin. The upper three formations, the Grande Ronde Basalt, the Wanapum Basalt, and the Saddle Mountains Basalt, collectively constitute the Yakima Basalt Subgroup (Swanson et a1. 1979). The Grande Ronde Basalt is the most extensive and voluminous formation within the Col umbia River Basalt Group, and represents about 87.5\% by volume of this group. Detailed descriptions of the individual formations and members can be found in DOE (1988).

Flows of the Columbia River Basalt Group are interbedded with and overlain by Miocene-Pliocene epiblastic and volcaniclastic sediments of the Ellensburg Formation (Myers et al. 1979). The age of the Ellensburg Formation is principally Miocene, but locally may be early Pliocene. Interbeds or members of the Ellensburg Formation are defined based on upper-and lowerbounding basalt flows. Correlative interbeds over the central Columbia Plateau and Pasco Basin include the Vantage, Mabton, Cold Creek, Selah, and Rattlesnake Ridge units.

Late Neogene (late Miocene to Pliocene) deposits younger than the Columbia River Basalt Group are represented by the Ringold Formation in the Pasco and Quincy basins. The fluvial-lacustrine Ringold Formation was deposited in generally east-west trending valleys by the ancestral Columbia River and its tributaries in response to the development of the Yakima Fold Belt. The Ringold Formation is classified into three facies associations or stratigraphic section types: 1) deposits of the migrating, throughgoing ancestral Columbia and/or Snake River systems; 2) overbank materials beyond the influence of the main river channel(s), and 3) fanglomerate deposits found around the margins of the basin (DOE 1988). 


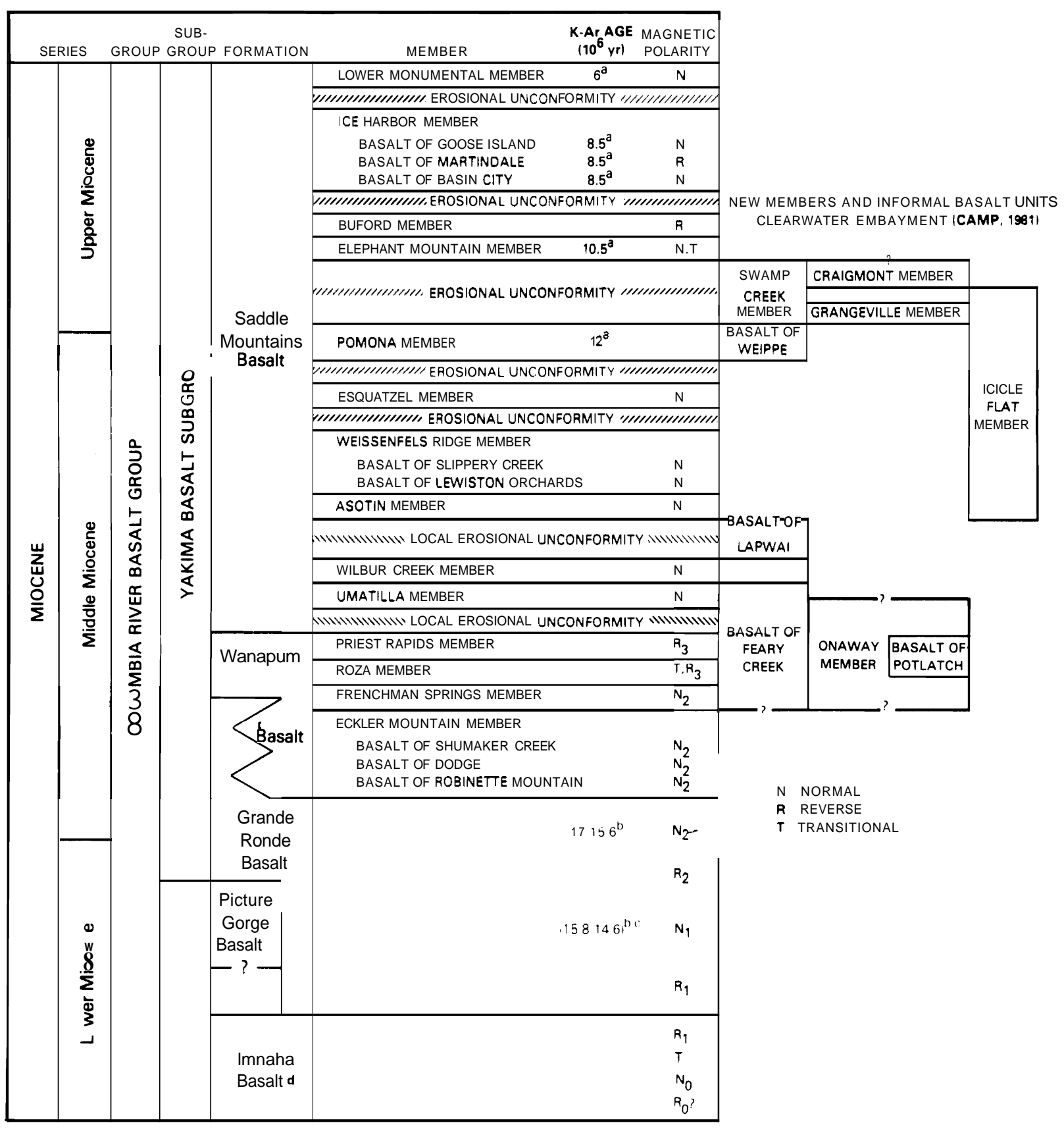

DDATA FROM MCKEE et al 119771

'DATA MOSTLY FROM WATKINS AND BAKS| 1974

GINFORMATION IN PARENTHESES REFERS TO PICTURE GORGE BASALT

'THE IMNAHA AND PICTURE GORGE BASALTS ARE NOWHERE KNOWN TO BE IN CONTACT

INTERPRETATION OF PRELIMINARY MAGNETOSTRATIGRAPHIC DATA SUGGESTS THAT THE IMNAHA IS OLDER

FIGURE 3.4. Stratigraphic Nomenclature for the Columbia River Basalt Group of the Columbia Plateau (DOE 1988) 


\subsubsection{Local Lithostratigraphy}

The major geologic units of the Hanford Site are, in ascending order: basement rocks of inferred origin and composition, the Columbia River Basalt Group with intercal ated sediments of the El lensburg Formation, the Ringold Formation, the Plio-Pleistocene unit, and the Hanford formation. Locally, Holocene sand, silt, and loess exist as surficial material. The stratigraphic column of units found in the Pasco Basin and at the Hanford Site is shown in Figure 3.5.

The subbasalt rocks and the Columbia River basalts are described in the preceding section. Because the Pasco Basin, the Hanford Site, and the proposed NPR site are within the region described above, the descriptions apply to these locations as well, with the exception that the Imnaha and Picture Gorge Basalts are not known to occur within the Pasco Basin (DOE 1988).

Within the Pasco Basin, deposits of the Ellensburg Formation are restricted primarily to the Wanapum and Saddle Mountain Basalts, and the lateral extent and thickness generally increase upward in the section (DOE 1988).

An eolian silt and fine sand (the Plio-Pleistocene unit) overlies the Ringold Formation in the western part of the Hanford Site (Brown 1960). This silty fine sand to sandy silt was deposited when the wind reworked and redeposited Ringold sediments. Relatively high caliche contents are found in much of this unit.

The Hanford formation lies on the eroded surface of the PlioPleistocene unit, the Ringold Formation, or locally, on the basalt bedrock. The Hanford formation consists of catastrophic flood sediments that were deposited when ice dams in western Montana and northern Idaho were breached and massive volumes of water spilled abruptly across eastern and central Washington. The floods scoured the land surface, locally eroding the Ringold Formation, the basalts, and sedimentary interbeds, leaving a network of buried channels crossing the Pasco Basin (Ta7lman et al. 1979). Thick sequences of sediments were deposited by several episodes of Pleistocene flooding with the last major flood sequence dated at about 13,000 years before present (Myers et al. 1979). These sediments have locally been 


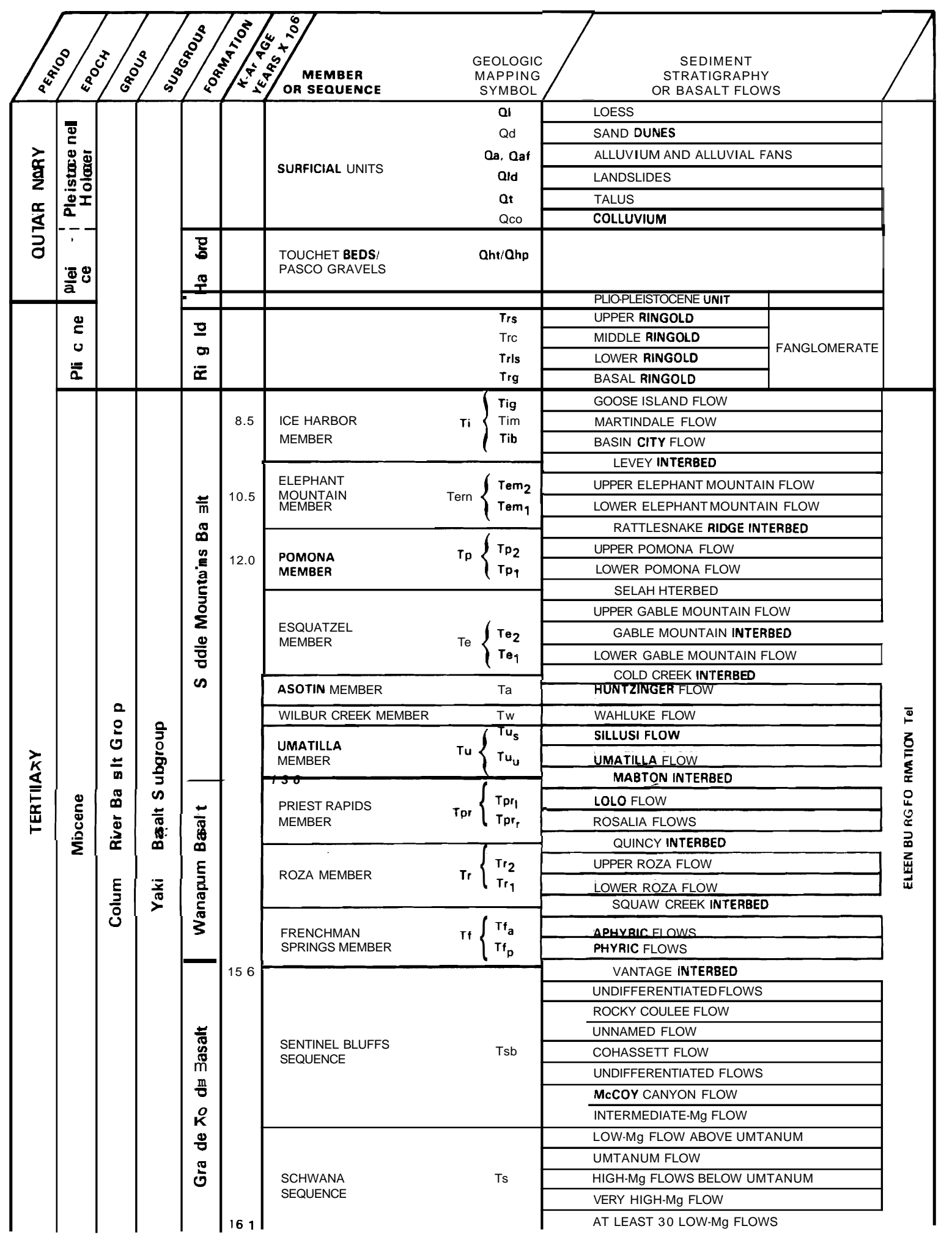

FIGURE 3.5. Stratigraphic Units Present in the Pasco Basin (DOE 1986) 
divided into two main facies, termed the "Pasco Gravels" facies and the "Touchet Beds" facies (Myers et a1. 1979).

Volcanic deposits in the Pasco Basin are limited to occasional, thin layers of air-fall tephra from a few millimeters to $10 \mathrm{~m}$ in thickness. Eolian sediments consisting of loess and sand dunes (both active and inactive) locally veneer the surface of the Hanford Site.

The proposed NPR site area has been generally characterized as part of the description and characterization of the Hanford Site. In addition, the environmental characterization of the former Skagit/Hanford nuclear plant location, the studies for the FFTF, and the various studies associated with the WPSS WNP 2 and $1 / 4$ are adjacent to the site area (Figure 1.1). These studies provide information and data that directly bound the site. $\$$ major breaks or boundaries in the physical environment are known to exist within the bounded area.

The topography of the site area is generally flat to gently undulating with scattered low sand dunes. A bench in the western half of the site area is marked by about 16-m greater elevation than the eastern part. The bench is a low relief feature with scattered slight depressions. Elevations vary from about $128 \mathrm{~m}$ above mean sea level (MSL) at the eastern end of the site area to about $158 \mathrm{~m}$ above at the western side.

The surface material at the site area is essentially fine loose sand of the Hanford Formation and wind deposited dune sand. The area contains some stabilized sand dunes as well as active low dunes to the northwest and east and larger dunes northeast of the area with relief of about $6 \mathrm{~m}$. The dunes are moving northeastward and are not expected to influence the site (Watson et al. 1984).

The Hanford formation is about 6-m thick and the Ringold Formation about 53- to 60-m thick at the WPPS sites at the eastern end of the proposed NPR site. At the former Skagit/Hanford site at the northwestern corner of the proposed NPR site, the Hanford formation is about 60-m thick, and the Ringold Formation is about $152-\mathrm{m}$ thick. The thicknesses of the Hanford and Ringold Formations at the FFTF, the southwestern corner of the site area, are about 
$60 \mathrm{~m}$ and $140 \mathrm{~m}$, respectively. Saddle Mountains Basalt underlies the Ringold Formation and can be considered bedrock at the proposed NPR site area.

\subsection{GEOLOGIC STRUCTURES}

This section describes the structural setting and features of the Col umbia Plateau and of the Hanford Site. A generalized structure mp of the central Columbia Plateau is shown in Figure 3.6.

\subsubsection{Reqional Geoloqic Structures}

The Columbia Plateau is divided informally into three structural subprovinces: 1) Palouse, 2) Blue Mountains, and 3) Yakima Fold Belt (Figure 3.7). It should be noted that these are not physiographic subprovinces, even though some of the names ma be the same.

The Palouse subprovince consists of a northern part (the Palouse Slope) and a southern part (the Clearwater Embayment). The Palouse Slope is a regional slope that dips gently toward the central Columbia Plateau and exhibits only mild structural deformation compared to the other structural subprovinces. The Clearwater Embayment consists of structural basins and uplifted blocks that are tilted, gently folded, and broken by numerous faults (DOE 1988).

The Blue Mountains subprovince is a structurally diverse region dominated by the complexly folded Blue Mountains anticlinorium in the northern part and a series of fault- and fold-bounded basins in the central and southern parts.

All but the easternmost part of the Pasco Basin is within the Yakima Fold Belt structural subprovince (DOE 1988). The Yakima Fold Belt contains four major structural elements: 1) Yakima Folds, 2) Cle Ellum-Wallula disturbed zone, 3) Hog Ranch-Naneum anticline, and 4) northwest-trending wrench faults.

The Yakima Folds are a series of continuous, narrow, asymmetric anticlines that have wavelengths between about 5 and $30 \mathrm{~km}$ and amplitudes cornmonly less than $1 \mathrm{~km}$. The anticlinal ridges are separated by broad synclines or basins. The Yakima Folds are believed to have developed under generally 


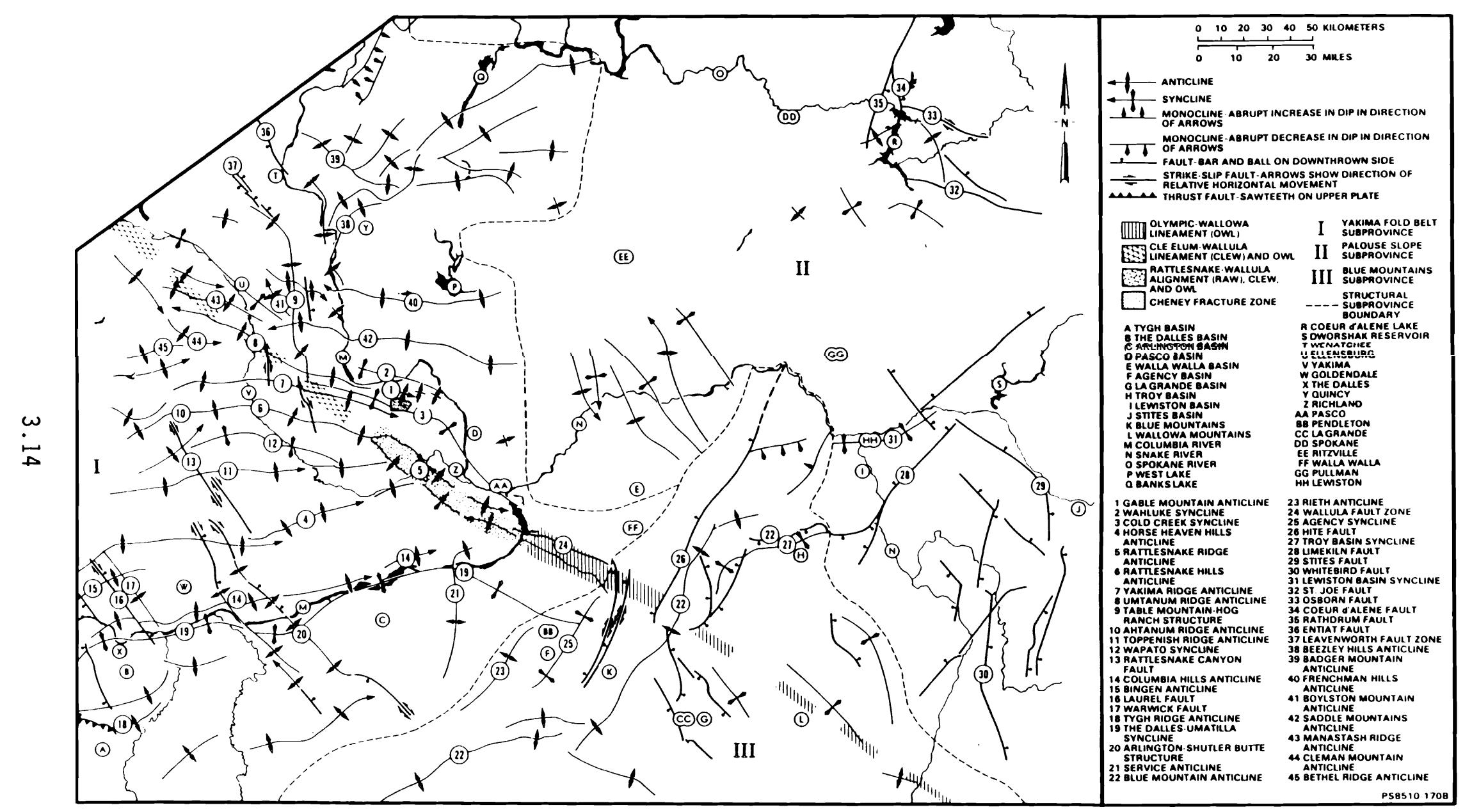

FIGURE 3.6. Structure Map of the Columbia Plateau (DOE 1988) 


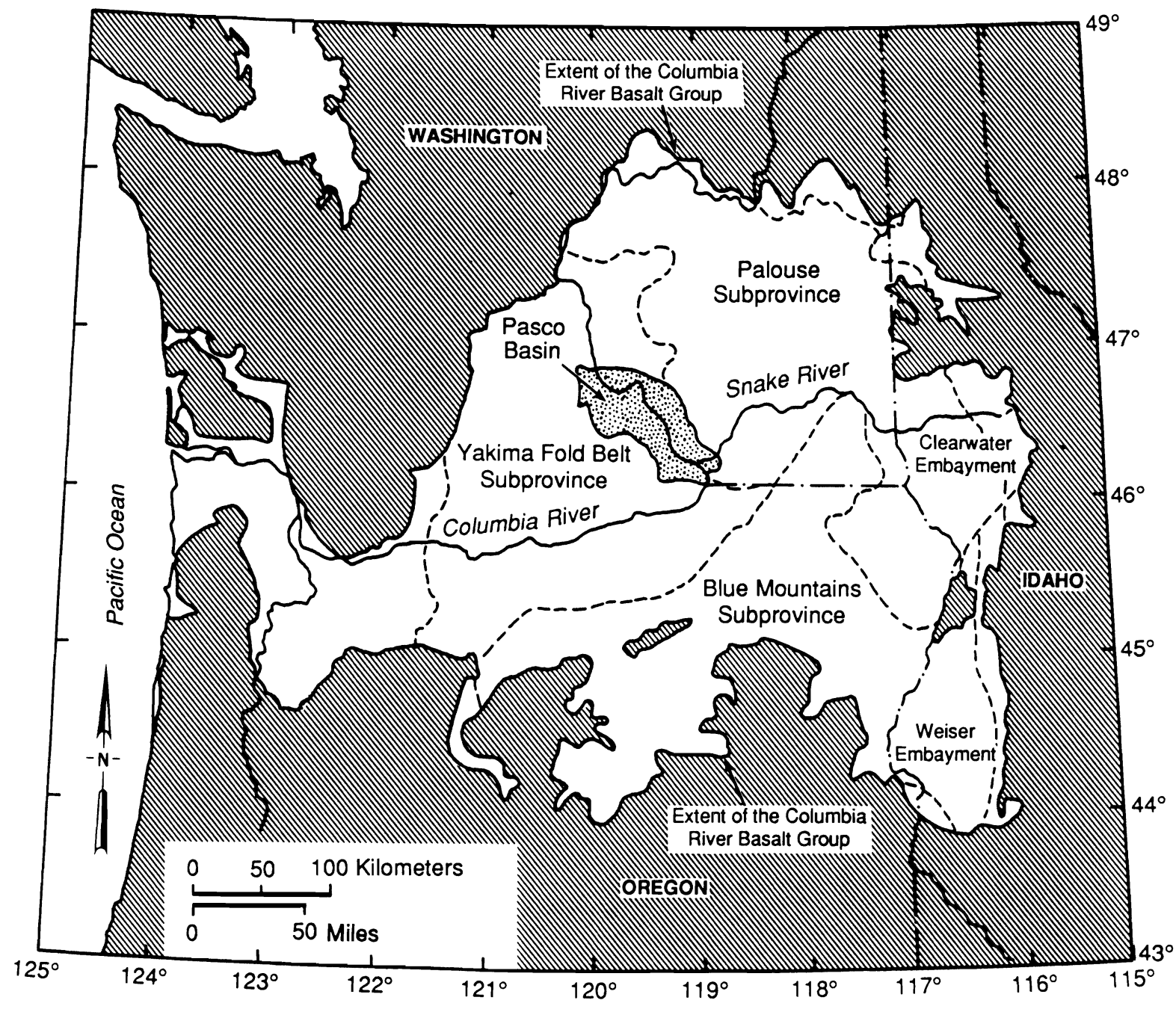

FGURE 3.7. Index Mp to Structural Subprovinces of the Columbia Plateau as Defined by the Distribution of Columbia River Basalt Flows East of the Cascade Range (DOE 1988)

north-south compression, but the origin and timing of the deformation along the fold structures are not well known (DOE 1988). Thrust or high-angle reverse faults are often found along both limbs of the anticlines, with the strike of the fault planes parallel or subparallel to the axis of the anticlines. There is very little direct field evidence to indicate Quaternary movement along these anticlinal ridges and one of three cases of suspected Quaternary faulting is along the central Gable Mountain fault in the Pasco Basin. 
The Cle Ellum-Wallula disturbed zone is the central part of a larger topographic alignment called the Olympic-Wallowa lineament that extends from the northwestern edge of the Olympic Mountains to the northern edge of the Wallowa Mountains in Oregon. The Cle Ellum-Wallula disturbed zone is a narrow zone about 10-km wide that transects the Yakima Fold Belt and informally has been divided into three structural domains: a broad zone of deflected or anomalous fold and fault trends, extending south of Cle Ellum, Washington, to Rattlesnake Mountain; a narrow belt of aligned domes and doubly plunging anticlines ("The Rattles") extending from Rattlesnake Mountain to Wallula Gap; and the Wallul a fault zone, extending from Wall ula Gap to the Blue Mountains. Evidence for Quaternary deformation has been reported for fourteen localities in or directly associated with the Cle Ell um-Wall ul a disturbed zone, but no evidence has been reported northwest of the Finley Quarry location (DOE 1988), about $60 \mathrm{~km}$ southeast of the approximate center of the Hanford Site.

The Hog Ranch-Naneum Ridge anticline is a broad structural arch that extends from southwest of Wenatchee, Washington, to at least the Yakima Ridge. This feature defines part of the northwestern boundary of the Pasco Basin, but little is known about the structural geology of this portion of the feature nor is the southern extent of the feature known.

Northwest-trending wrench faults have been mapped west of 120" W longitude in the Columbia Plateau (DOE 1988). The mean strike direction of the dextral wrench faults is $320^{\circ}$, but there are less numerous northeasttrending sinistral wrench faults that strike 013". These structures are not known to exist in the central Columbia Plateau.

\subsubsection{Local Geoloqic Structures}

Most known faults within the Hanford area are associated with anticlinal fold axes, are thrust or reverse faults although normal faults do exist, and were probably formed concurrently with the folding (DOE 1986). Existing known faults within the Hanford area include wrench faults with lengths of up to $3 \mathrm{~km}$ on Gable Mountain and the Rattlesnake-Wallula al ignment which has been interpreted as a right-1ateral strike-slip fault. The faults i,n Central Gable Mountain are considered capable by NRC criteria (10 CFR 100, 
Appendix A) in that they have slightly displaced the Hanford formation gravels, but their relatively short lengths give them low seismic potential. Also, there is no observed seismicity on or near Gable Mountain. The Rattlesnake-Wallula alignment is interpreted as possibly being capable, in part because of lack of any distinct evidence to the contrary and because this structure continues along the northwest trend of faults that appear active at Wallula Gap, some $56 \mathrm{~km}$ southeast of the central part of the Hanford Site (DOE 1986).

Strike-slip faults have not been observed cross cutting the Pasco Basin. Anticlinal ridges that bound the Pasco Basin have been mapped in detail, and except for some component of dextral movement on the Rattlesnake-Wallula alignment, no strike-slip faults similar to those in the western Yakima Fold Belt have been observed (DOE 1986). Wrench faults have been observed along the ridges at boundaries between geometrically coherent segments of the structures, as in the Saddle Mountains, but these faults are confined to the individual structures and formed as different geometries developed in the fold. Similar-type faults have been mapped on Gable Mountain and studied in detail. These features are also interpreted as wrench faults that are a response to folding.

In general, it has been found that for structures within the Hanford Site area the greatest deformation occurs in the hinge area of the anticlinal ridges and decreases with distance from that area (i.e., the greatest amount of tectonic jointing and faulting occurs in the hinge zone and decreases toward the gently dipping limbs). The faults usually exhibit low dips with small displacements, may be confined to the layer in which they occur, and die out to no recognizable displacement in short lateral distances (DOE 1986).

\subsection{VOLCANISM}

Quaternary volcanism has been limited to the extreme western margin of the Columbia Basin subprovince and is associated with the Cascade Range Province. Airfall tephra from at least three Cascade volcanoes has blanketed the central Columbia Plateau since the late Pleistocene. This tephra includes 
material from several eruptions of Mount St. Helens prior to the May 1980 eruption. Other volcanoes have erupted less frequently; two closely spaced eruptions from Glacier Peak about 11,200 years ago, and the eruption of Mount Mazama about 6,600 years ago. Generally tephra layers have not exceeded more than a few centimeters in thickness, with the exception of the Mount Mazama eruption when up to 10 an of tephra fell over eastern Washington (DOE 1988).

There are several major volcanoes in the Cascade Range west of the Hanford Site. The nearest volcano is Mount Adams, which is about $165 \mathrm{~km}$ from the Hanford Site, and the most active is Mount St. Helens, which is approximately $220 \mathrm{~km}$ west-southwest from Hanford.

A period of renewed volcanic activity at Mount St. Helens began in March 1980 and climaxed in a major eruption on May 18, 1980. This eruption resulted in about $1 \mathrm{~mm}$ of ash fall over a 9-hour period at the Hanford Site, which was near the southern edge of the ash dispersal plume. Smaller eruptions of steam and ash occurred through October 1980, but none of these deposited measurable amounts of ash at the site.

\subsection{SEISMICITY}

The historic record of earthquakes in the Pacific Northwest dates from about 1840. The early part of this record is based on newspaper reports of structural damage and human perception of the shaking, as classified by the Modified Mercalli Intensity (MMI) scale. The early record is probably incomplete because the region was sparsely populated. Seismic networks did not start providing earthquake locations and magnitudes in the Pacific Northwest until about 1960. A comprehensive network of seismic stations that provides accurate locating information for most earthquakes greater than Richter magnitude 2.5 was installed in eastern Washington in 1969. A summary of the seismicity of the Pacific Northwest, a detailed review of the seismicity of the Columbia Plateau and the Hanford Site, and a description of the seismic networks used to collect the data has been published (DOE 1988).

Large earthquakes (magnitude greater than Richter 7) in the Pacific Northwest have occurred in the vicinity of Puget Sound, Washington, and near the Rocky Mountains in eastern Idaho and western Montana. One of these 
events, which occurred near Vancouver Island in 1946, produced a maximum MM of VIII and a magnitude of 7.3. Another large event, which occurred near Olympia, Washington in 1949, had a maximum intensity of MM VIII and a magnitude of 7.1. The two largest events near the Rocky Mountains were the 1959 Hebgen Lake earthquake in western Montana, which had a magnitude of 7.5 and an MM of X, and the 1983 Borah Peak earthquake in eastern Idaho, which had a magnitude of 7.3 and an MM of IX.

A large earthquake of uncertain location occurred in north-central Washington in 1872. This event had an estimated maximum MM ranging from VIII to $\mathrm{X}$ and an estimated magnitude of approximately 7. The distribution of intensities suggest a location within a broad region between Lake Chelan, Washington and the British Columbia border (Malone and Bor 1979).

The locations of all earthquakes with MMls of IV or larger and with magnitudes of 4 or greater that occurred in the Columbia Plateau prior to 1969 are shown in Table 3.1 and Figure 3.8. Table 3.2 and Figure 3.9 show the locations of all earthquakes with magnitudes of 3 or greater that occurred in the Columbia Plateau from March 23, 1969 to October 31, 1989. The largest known earthquake in the Columbia Plateau occurred in 1936 around MittonFreewater, Oregon. This earthquake had a magnitude of 5.75 and a maximum MM of VII, and was followed by a number of aftershocks that indicate a northeast-trending fault plane. Other earthquakes with magnitudes of 5 or larger and/or intensities of VI are located along the boundaries of the Columbia Plateau in a cluster near Lake Chelan extending into the northern Cascade Range; in northern Idaho and Washington; and along the boundary between the western Columbia Plateau and the Cascade Range. Three MM VI earthquakes have occurred within the Columbia Plateau, including one event in the Milton-Freewater region in 1921, one near Yakima, Washington in 1892, and one near Umatilla, Oregon in 1893.

In the central portion of the Columbia Plateau, the largest earthquakes near the Hanford Site occurred in 1918 and 1973. These two events had magnitudes of 4.4 and MMs of V, and were located north of the Hanford Site. Earthquakes often occur in spatial and temporal clusters in the central Columbia Plateau, and are termed "earthquake swarms." The region north and 
TABLE 3.1. Historical Earthquake Catalog for Eastern Washington and Surrounding Areas (44.9-49.0N, 115.5-121.5W) through March 23, 1969 (Rohay 1989). Includes A11 Earthquakes with an MMI of IV or Larger, and Earthquakes without an MMI that had Magnitudes Greater than 4.

\begin{tabular}{|c|c|c|c|c|c|c|}
\hline Date & $\begin{array}{l}\text { Time } \\
\text { GMT }\end{array}$ & $\begin{array}{l}\text { Latitude } \boldsymbol{v} \text { ) } \\
\text { Deqrees }\end{array}$ & $\begin{array}{l}\text { Longitude } \\
\text { Degrees } \\
\end{array}$ & $\underline{M M I}$ & $\begin{array}{l}\text { Magnjtude } \\
\mathrm{ML}\end{array}$ & Remarks \\
\hline 1891 Sep 2 & $10: 3 g^{(c)}$ & $47.190 \mathrm{~N}$ & $118.409 \mathrm{~W}$ & IV & & Ritzville, WA \\
\hline 1891 Sep 17 & $94: 30$ & $44.940 N$ & $121.033 W$ & IV & & Salem, OR \\
\hline 1893 Mar 5 & (b) & $45.900 \mathrm{~N}$ & $119.333 W$ & VI & & Umatilla. OR \\
\hline 1897 Dec 15 & (b) & $47.800 \mathrm{~N}$ & $120.000 \mathrm{~W}$ & V & & Lakeside, WA \\
\hline 1905 Oct 18 & $23: \quad(\mathrm{C})$ & $47.800 \mathrm{~N}$ & $120.000 \mathrm{~W}$ & V & & Chelan, WA \\
\hline 1906 Jan 2 & (b) & $48.700 \mathrm{~N}$ & $117.800 \mathrm{~W}$ & VI & & Stevens County, WA \\
\hline 1906 Nov 2 & $01: 49$ & $48.500 \mathrm{~N}$ & $117.989 \mathrm{~W}$ & V & & Colville, WA \\
\hline 1911 Jul 5 & $08: 90$ & $46.998 N$ & $120.540 \mathrm{~W}$ & V & & El lensburg, WA \\
\hline 1913 Oct 14 & $23: 90$ & $45.700 \mathrm{~N}$ & $117.190 \mathrm{~W}$ & V & & Seven Devils Region. OR \\
\hline 1915 Mar 5 & $05: 10$ & $47.836 \mathrm{~N}$ & $120.020 \mathrm{~W}$ & IV & & Lakeside, WA \\
\hline 1915 Mar 5 & $95: 3 \emptyset$ & $47.830 N$ & $120.020 \mathrm{~W}$ & IV & & Lakeside. WA \\
\hline 1915 Ju 18 & $20: 54$ & $47.836 \mathrm{~N}$ & $120.020 \mathrm{~W}$ & IV & & Lakeside. WA \\
\hline 1915 Aug 18 & $14: 95$ & $48.500 \mathrm{~N}$ & $121.400 \mathrm{~W}$ & V & & \\
\hline 1915 Dec 10 & $20: 45$ & $47.672 \mathrm{~N}$ & $117.405 \mathrm{~W}$ & IV & & Spokane, WA \\
\hline 1918 Feb 21 & (b) & $46.867 N$ & $121.333 W$ & IV & & Bumping Lake, WA \\
\hline 1918 Feb 28 & $23: 15$ & $46.500 \mathrm{~N}$ & $120.500 \mathrm{~W}$ & V & & Yakima, WA \\
\hline 1918 Mar 12 & $93: 26$ & $47.600 \mathrm{~N}$ & $117.980 \mathrm{~W}$ & V & & Rathdrum, ID \\
\hline 1924 Jan 6 & $13: 99$ & $46.070 \mathrm{~N}$ & $118.328 W$ & IV & & Walla Walla, WA \\
\hline 1924 Jan 6 & $23: 10$ & $45.800 \mathrm{~N}$ & $118.300 \mathrm{~W}$ & $V$ & & Milton. Weston, OR \\
\hline 1924 May 27 & $00: 19$ & $46.070 \mathrm{~N}$ & $118.328 \mathrm{~W}$ & IV & & Walla Walla, WA \\
\hline 1925 Nov 28 & $01: 25$ & $47.500 \mathrm{~N}$ & $116.080 \mathrm{~W}$ & & 4.30 & \\
\hline 1926 Apr 23 & $13: 56$ & $46.07 \emptyset \mathrm{N}$ & $118.328 \mathrm{~W}$ & IV & & Walla Walla. WA \\
\hline 1926 Oct 17 & $02: 45$ & $45.730 \mathrm{~N}$ & $121.483 W$ & V & & White Salmon, WA \\
\hline 1926 Nov 27 & $18: 25^{(\mathrm{C})}$ & $47.500 \mathrm{~N}$ & $116.000 \mathrm{~W}$ & V & & Rathdrum, ID \\
\hline 1926 Dec 30 & $17: 57$ & $47.7000 \mathrm{~N}$ & $120.200 \mathrm{~W}$ & VI & & Chelan-E. Central. WA \\
\hline 1927 Jan 3 & $\emptyset 4: 58$ & $47.593 N$ & $120.658 W$ & VI & & Leavenworth. WA \\
\hline 1930 Sep 3 & $13: \emptyset \emptyset$ & $47.300 \mathrm{~N}$ & $117.800 \mathrm{~W}$ & V & & Lamont, WA \\
\hline 1931 Dec 8 & $14: 25$ & $47.838 \mathrm{~N}$ & $120.020 \mathrm{~W}$ & IV & & Lakeside-Chelan Falls. WA \\
\hline 1933 May 31 & $20: 20$ & $47.842 \mathrm{~N}$ & $120.013 \mathrm{~W}$ & IV & & Chelan, WA \\
\hline 1933 May 31 & $20: 30$ & $47.842 \mathrm{~N}$ & $120.013 \mathrm{~W}$ & IV & & Chelan. WA \\
\hline 1934 Mar 9 & $16: 90$ (c) & $47.830 \mathrm{~N}$ & $120.020 \mathrm{~W}$ & IV & & Lakeside, WA \\
\hline 1934 Sep 18 & 24: (c) & $46.998 N$ & $120.540 \mathrm{~W}$ & V & & Ellensburg. WA \\
\hline 1934 Sep 22 & $11: 30(\mathrm{c})$ & $46.998 N$ & $120.540 \mathrm{~W}$ & IV & & El lensburg. WA \\
\hline 1934 Sep 22 & $17: 37^{(c)}$ & $46.998 N$ & $120.540 \mathrm{~W}$ & IV & & Ellensburg. WA \\
\hline
\end{tabular}


TABLE 3.1. (contd)

\begin{tabular}{|c|c|c|c|c|c|c|}
\hline Date & $\begin{array}{l}\text { Time } \\
\text { GMT }\end{array}$ & $\begin{array}{l}\text { Latitude }^{(a)} \\
\text { Desrees }\end{array}$ & $\begin{array}{l}\text { Longitude } \\
\text { Degrees }\end{array}$ & MMI & $\underset{M}{\operatorname{Magn} j t u d e}$ & Remarks \\
\hline 1934 Sep 26 & $16: 15^{(\mathrm{c})}$ & $46.998 \mathrm{~N}$ & $120.540 \mathrm{~W}$ & V & & El lensburg, WA \\
\hline 1934 Sep 26 & $16: 45^{(c)}$ & 46.998̣N & $120.540 \mathrm{~W}$ & V & & Ellensburg. WA \\
\hline 1934 Sep 26 & $21: 15^{(c)}$ & $46.998 \mathrm{~N}$ & $120.540 \mathrm{~W}$ & V & & Ellensburg. WA \\
\hline 1934 Oct 4 & $62: 26^{(c)}$ & $46.998 \mathrm{~N}$ & $120.540 \mathrm{~W}$ & IV & & El lensburg, WA \\
\hline 1934 Oct 11 & $21: 19^{(c)}$ & $46.998 \mathrm{~N}$ & $120.540 \mathrm{~W}$ & IV & & Ellensburg, WA \\
\hline 1934 Oct 19 & $23: 31(c)$ & $46.998 \mathrm{~N}$ & $120.540 \mathrm{~W}$ & V & & El lensburg, WA \\
\hline 1934 Oct 29 & $18: 36^{(\mathrm{C})}$ & $46.998 \mathrm{~N}$ & $120.540 \mathrm{~W}$ & IV & & El lensburg. WA \\
\hline 1934 Nov 1 & $07: 28^{(c)}$ & $46.998 \mathrm{~N}$ & $120.540 \mathrm{~W}$ & V & & El lensburg, WA \\
\hline 1934 Nov 2 & $15: 17^{(\mathrm{c})}$ & $46.998 \mathrm{~N}$ & $120.540 \mathrm{~W}$ & V & & El lensburg, WA \\
\hline 1935 Jul 9 & $22: 45$ & $47.700 \mathrm{~N}$ & $120.000 \mathrm{~W}$ & V & & Chelan Falls, WA \\
\hline 1935 Oct 12 & $\emptyset 1: \emptyset 3$ & $47.662 \mathrm{~N}$ & $120.223 W$ & V & & Entiat, WA \\
\hline 1935 Nov 1 & $\emptyset 3: 35$ & $47.472 N$ & $115.925 \mathrm{~W}$ & IV & & Wallace. ID \\
\hline $1936 \mathrm{Jul} 16$ & $97: 07$ & $46.208 \mathrm{~N}$ & $118.233 W$ & VII & 5.75 & Milton-Freewater, OR \\
\hline 1936 Jul 18 & $16: 30$ & $45.933 N$ & $118.383 W$ & V & & Mi lton-Freewater, OR \\
\hline 1936 Jul 30 & $11: 20$ & $45.935 \mathrm{~N}$ & $118.338 \mathrm{~W}$ & IV & & Freewater. OR \\
\hline 1936 Jul 30 & $11: 20$ & $45.935 N$ & $118.338 \mathrm{~W}$ & IV & & Freewater, OR \\
\hline 1936 Jul 30 & $12: \varnothing 0$ & $45.935 N$ & $118.388 \mathrm{~W}$ & IV & & Freewater, OR \\
\hline $1936 \mathrm{Jul} 30$ & $12: 20$ & $46.979 \mathrm{~N}$ & $118.328 \mathrm{~W}$ & IV & & Walla Walla, WA \\
\hline 1936 Aug 4 & $09: 19$ & $45.800 \mathrm{~N}$ & $118.600 \mathrm{~W}$ & V & & Helix, OR \\
\hline 1936 Aug 28 & $\emptyset 4: 39$ & $45.933 N$ & $118.383 W$ & V & & Milton-Freewater, OR \\
\hline 1937 Feb 9 & $22: 20$ & $46.070 \mathrm{~N}$ & $118.328 \mathrm{~W}$ & IV & & Walla Walla, WA \\
\hline 1937 Feb 9 & $22: 20$ & $46.070 \mathrm{~N}$ & $118.328 \mathrm{~W}$ & IV & & Walla Walla, WA \\
\hline 1937 Jun 4 & $14: 43$ & $46.979 \mathrm{~N}$ & $118.328 \mathrm{~W}$ & IV & & Walla Walla, WA \\
\hline 1938 Aug 11 & $18: 52$ & $45.935 N$ & $118.388 \mathrm{~W}$ & IV & & Milton, OR \\
\hline 1938 oct 27 & $23: 10$ & $45.935 \mathrm{~N}$ & $118.388 \mathrm{~W}$ & IV & & Milton. OR \\
\hline 1939 Jan 26 & $07: 59$ & $45.700 \mathrm{~N}$ & $118.700 \mathrm{~W}$ & IV & & Mission, OR \\
\hline 1940 Mar 24 & $\emptyset 3: \emptyset 4$ & $46.909 \mathrm{~N}$ & $121.200 \mathrm{~W}$ & IV & & Mt. Rainier, WA \\
\hline 1941 Apr 7 & $69: 25$ & $48.300 \mathrm{~N}$ & $119.600 \mathrm{~W}$ & VI & 5.00 & \\
\hline 1941 Apr 12 & $17: 40$ & $47.648 \mathrm{~N}$ & $120.069 \mathrm{~W}$ & IV & & Waterville, WA \\
\hline 1942 Feb 23 & $14: 93$ & $47.600 \mathrm{~N}$ & $120.200 \mathrm{~W}$ & V & & Wenatchee-Chelan Fa 11s, WA \\
\hline 1942 Jun 12 & $99: 30$ & $44.900 \mathrm{~N}$ & $117.100 \mathrm{~W}$ & V & & Halfway and Pine, OR \\
\hline 1942 Oct 14 & $11: 30$ & $48.319 \mathrm{~N}$ & $120.652 W$ & V & & Stehekin, WA \\
\hline 1942 Nov 1 & $18: 50$ & $48.009 \mathrm{~N}$ & $116.700 \mathrm{~W}$ & VI & 5.50 & Sandpoint, I D \\
\hline 1943 Apr 24 & $00: 10$ & $47.300 \mathrm{~N}$ & $120.600 \mathrm{~W}$ & VI & & Leavenworth, WA \\
\hline 1943 Sep 22 & $21: 5 g^{(c)}$ & $47.967 \mathrm{~N}$ & $119.000 \mathrm{~W}$ & IV & & Grand Coulee, WA \\
\hline 1944 Sep 2 & $\emptyset 1: 25$ & $46.070 \mathrm{~N}$ & $118.328 W$ & IV & & Walla Walla. WA \\
\hline 1944 Sep 20 & $\emptyset 3: \emptyset 0$ & $44.900 \mathrm{~N}$ & $116.900 \mathrm{~W}$ & IV & & Rockville, DR. \\
\hline 1944 Oct 31 & $11: 34$ & $47.800 \mathrm{~N}$ & $120.600 \mathrm{~W}$ & V & & \\
\hline 1944 Dec 25 & $13: 12$ & $47.662 \mathrm{~N}$ & $120.223 W$ & IV & & Entiat, WA \\
\hline 1945 Jan 4 & $92: 34$ & $47.662 \mathrm{~N}$ & $120.223 W$ & V & & Entiat, WA \\
\hline 1945 Feb 27 & $11: \emptyset \emptyset$ & $48.480 \mathrm{~N}$ & $121.190 \mathrm{~W}$ & IV & & Winthrop, WA \\
\hline 1945 Mar 2 & $07: 54$ & $47.662 \mathrm{~N}$ & $120.223 \mathrm{~W}$ & IV & & Entiat, WA \\
\hline 1945 Sep 23 & $02: 40$ & $46.079 \mathrm{~N}$ & $118.328 \mathrm{~W}$ & IV & & Walla Walla, WA \\
\hline 1946 Feb 5 & $16: 12$ & $47.800 \mathrm{~N}$ & $120.200 \mathrm{~W}$ & IV & & Chelan-Ardenvoir, WA \\
\hline 1946 Feb 6 & $93: 2 \emptyset$ & $48.527 N$ & $121.430 \mathrm{~W}$ & IV & & Marblemount. WA \\
\hline 1947 Dec 22 & $10: 30$ & $47.662 \mathrm{~N}$ & $120.223 W$ & IV & & Entiat, WA \\
\hline 1948 Jan 13 & $\emptyset 6: 55$ & $47.900 \mathrm{~N}$ & $120.300 \mathrm{~W}$ & V & & Lucerne-Waterville, WA \\
\hline 1948 Aug 28 & $22: 25$ & $47.957 \mathrm{~N}$ & $117.475 \mathrm{~W}$ & IV & & Deer Park, WA \\
\hline 1948 oct 25 & $19: 50$ & $47.842 N$ & $120.013 \mathrm{~W}$ & IV & & Chelan, WA \\
\hline 1948 Dec 20 & $16: 18$ & $44.996 \mathrm{~N}$ & $120.215 \mathrm{~W}$ & IV & & Fossil, OR \\
\hline $1949 \operatorname{Mar} 15$ & $20: 53$ & $45.500 \mathrm{~N}$ & $117.000 \mathrm{~W}$ & & 4.80 & \\
\hline 1949 Oct 20 & $16: 00$ & $48.500 \mathrm{~N}$ & $120.500 \mathrm{~W}$ & IV & & Lost River. WA \\
\hline 1950 Mar 8 & $\emptyset 6: 25$ & $47.662 \mathrm{~N}$ & $120.223 W$ & IV & & Entiat. WA \\
\hline
\end{tabular}


TABLE 3.1. (contd)

\begin{tabular}{|c|c|c|c|c|c|c|}
\hline Date & $\begin{array}{l}\text { Time } \\
\text { GMT }\end{array}$ & $\begin{array}{l}\text { Latitude } \\
\text { Degrees }\end{array}$ & $\begin{array}{l}\text { Longitude } \\
\text { Deqrees } \\
\end{array}$ & $\underline{M M I}$ & $\begin{array}{c}\text { Magn } j t u d e \\
{ }_{M L}\end{array}$ & Remarks \\
\hline 1950 Jun 25 & $23: 45$ & $47.491 N$ & $117.575 \mathrm{~W}$ & IV & & Cheney. WA \\
\hline 1951 Jan 4 & $13: 45$ & $47.700 \mathrm{~N}$ & $120.000 \mathrm{~W}$ & v & & Chelan-Watervi\}le, WA \\
\hline 1951 Jan 7 & $22: 45$ & $45.900 \mathrm{~N}$ & $119.200 \mathrm{~W}$ & V & & McNary, OR \\
\hline 1952 Mar 4 & $19: 42$ & $47.672 \mathrm{~N}$ & $117.405 \mathrm{~W}$ & $v$ & & Spokane, WA \\
\hline 1952 Sep 9 & $99: 30$ & $48.698 \mathrm{~N}$ & $116.315 \mathrm{~W}$ & IV & & Bonners Ferry, ID \\
\hline 1952 Sep 9 & $99: 45$ & $48.698 \mathrm{~N}$ & $116.315 \mathrm{~W}$ & IV & & Bonners Ferry. ID \\
\hline 1953 Sep 9 & $69: 30$ & $48.698 N$ & $116.315 \mathrm{~W}$ & IV & & Bonners Ferry, ID \\
\hline 1954 May 23 & $13: 41$ & $48.342 N$ & $120.137 W$ & V & & Twisp, WA \\
\hline 1954 Jun 8 & $00: 16$ & $47.500 \mathrm{~N}$ & $116.000 \mathrm{~W}$ & $v$ & & Mortaern, C. D'Alene, ID \\
\hline $1955 \mathrm{Feb} 6$ & (b) & $47.967 \mathrm{~N}$ & $119.000 \mathrm{~W}$ & IV & & Grand Coulee, WA \\
\hline 1955 May 31 & $23: 35$ & $47.680 \mathrm{~N}$ & $116.773 W$ & IV & & Coeur D'Alene, ID \\
\hline 1956 Feb 24 & $22: 90$ & $47.900 \mathrm{~N}$ & $119.100 \mathrm{~W}$ & v & & Electric City, WA \\
\hline 1957 Nov 1 & $10: 12$ & $46.700 \mathrm{~N}$ & $121.500 \mathrm{~W}$ & v & 4.20 & \\
\hline 1957 Dec 18 & $23: 25$ & $47.500 \mathrm{~N}$ & $116.000 \mathrm{~W}$ & VI & 5.00 & \\
\hline 1958 Apr 12 & $\emptyset \emptyset: \emptyset \emptyset$ & $47.900 \mathrm{~N}$ & $119.100 \mathrm{~W}$ & IV & & Electric City, WA \\
\hline 1958 Apr 12 & $22: 37$ & $48.000 \mathrm{~N}$ & $120.000 \mathrm{~W}$ & VI & 4.10 & \\
\hline 1959 Jan 21 & $07: 15$ & $46.970 \mathrm{~N}$ & $118.328 \mathrm{~W}$ & IV & & Walla Walla, WA \\
\hline 11 1גונ 1959 & 15: (c) & $47.600 \mathrm{~N}$ & $119.300 \mathrm{~W}$ & IV & & Deep Lake. WA \\
\hline 1959 Aug 6 & $93: 44$ & $47.800 \mathrm{~N}$ & $119.900 \mathrm{~W}$ & VI & 4.40 & Chelan, WA \\
\hline 1959 Nov 9 & $21: 10$ & $45.353 \mathrm{~N}$ & $119.550 \mathrm{~W}$ & IV & & Heppner. OR \\
\hline 1961 May 22 & $91: 57$ & $47.600 \mathrm{~N}$ & $120.200 \mathrm{~W}$ & IV & & Entiat, WA \\
\hline 1961 Jun 28 & $10: 22$ & $47.537 \mathrm{~N}$ & $120.293 W$ & IV & & Rocky Reach Dam, WA \\
\hline 1961 Oct 31 & $92: 35$ & $48.4000 \mathrm{~N}$ & $120.000 \mathrm{~W}$ & v & 4.30 & \\
\hline 1961 Oct 31 & $63: 34$ & $48,400 \mathrm{~N}$ & $120.000 \mathrm{~W}$ & v & & Okanogan, WA \\
\hline 1962 Jan 15 & $95: 29$ & $47.800 \mathrm{~N}$ & $120.200 \mathrm{~W}$ & v & 4.30 & \\
\hline 1963 Dec 22 & $02: 54$ & $48.590 \mathrm{~N}$ & $119.760 \mathrm{~W}$ & v & 4.40 & \\
\hline 1965 Apr 28 & $19: \varnothing \theta^{(c)}$ & $48.600 \mathrm{~N}$ & $116.900 \mathrm{~W}$ & v & 4.30 & \\
\hline 1965 Nov 7 & $16: 41$ & $44.900 \mathrm{~N}$ & $117.000 \mathrm{~W}$ & & $4.30^{(d)}$ & \\
\hline $1966 \mathrm{Jul} 23$ & $91: 57$ & $47.200 \mathrm{~N}$ & $119.500 \mathrm{~W}$ & & 4.30 & \\
\hline 1966 Dec 30 & $93: 51$ & $44.990 \mathrm{~N}$ & $117.000 \mathrm{~W}$ & & $4.2 \theta^{(d)}$ & \\
\hline
\end{tabular}

(a) Locations of early events are often the location of maximum reported intensity (listed in remarks) and do not indicate precision better than $0.1^{\circ}$.

(b) ML - Local Richter magnitude.

(c) Local time [not converted to equivalent of Greenwich Mean Time (GMT)]. Generally indicates a greater uncertainty in time. For events where no time is provided, the date indicates the best approximation of the time of occurrence from available information sources.

(d) Body wave magnitude [mb (approximately equal to ML)]. Local Richter magnitude (ML) not available. 


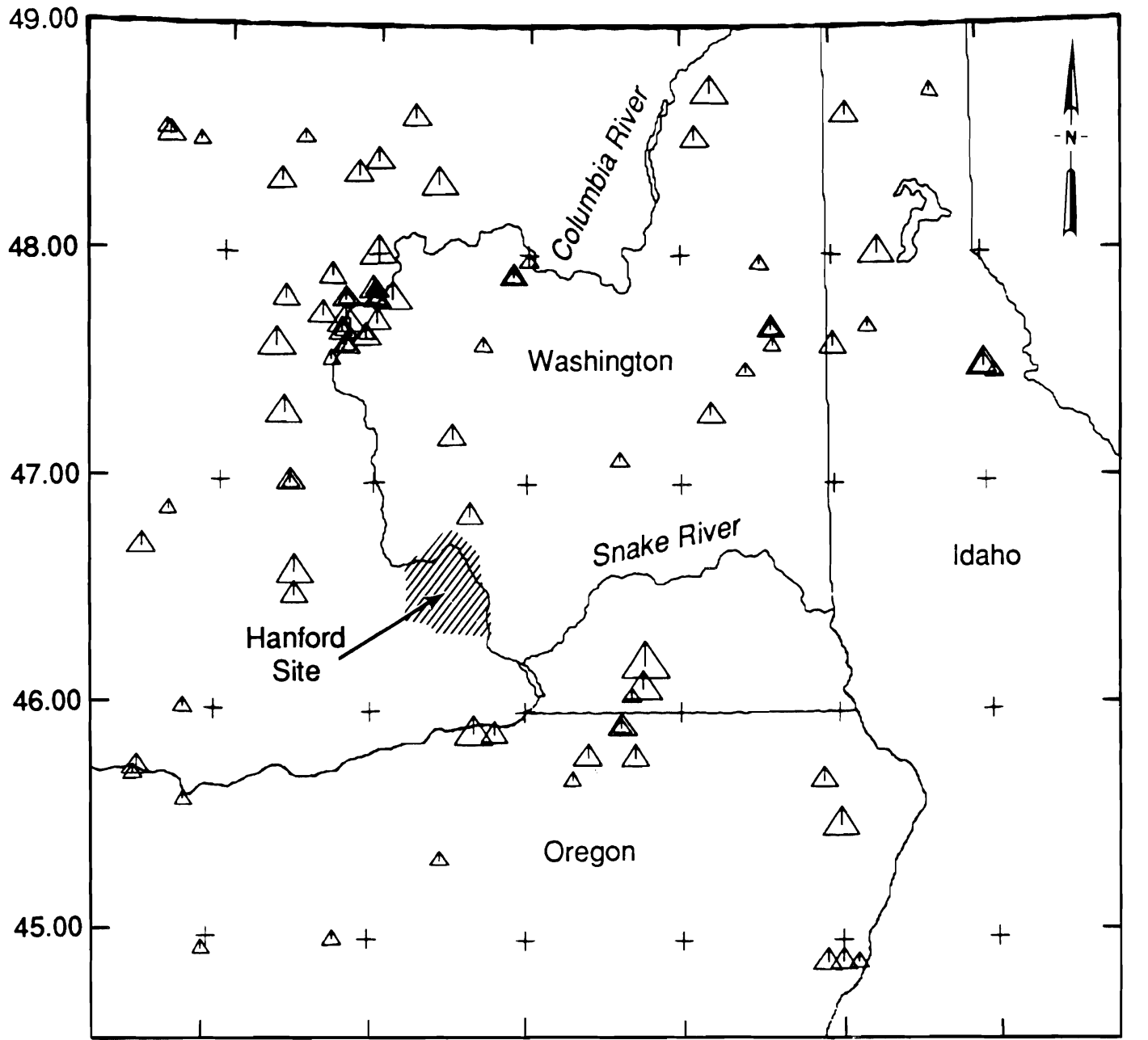

$$
\begin{aligned}
& \text { Equivalent } \\
& \text { Richter } \\
& \text { Magnitude } \\
& \text { a } \frac{\text { MMI }}{\text { IV }} \frac{\text { (Calculated) }}{3.3-4.0}
\end{aligned}
$$

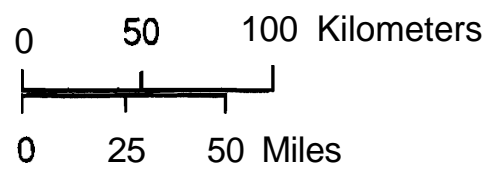

+ Latitude/Longitude Intersection

FIGURE 3.8. Historical Seismicity of the Columbia Plateau and Surrounding Areas. All Earthquakes Between 1850 and March 23, 1969 with a MMI Intensity of I V or Larger and a Magnitude of 4 or Larger are Shown (see Table 3.1). 
TABLE 3.2. Instrumental Earthquake Catalog for the Columbia Plateau and Surrounding Area. Includes All Earthquakes with Coda-Length Magnitude 3 or Larger from March 23, 1969 to October 31, 1989. [Univ. of Washington Online Earthquake Catalog (database)].

\begin{tabular}{|c|c|c|c|c|c|c|}
\hline Date & $\begin{array}{l}\text { Time } \\
\text { aMT }\end{array}$ & $\begin{array}{l}\text { Latitude } \\
\text { Deqrees } \\
\end{array}$ & $\begin{array}{l}\text { Longitude } \\
\text { Dearees }\end{array}$ & $\begin{array}{l}\text { Depth } \\
\text { kilo- } \\
\text { meters } \\
\end{array}$ & 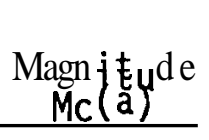 & $\underline{\text { No }}$ \\
\hline 1969 Aug 02 & $03: 04$ & $47.346 \mathrm{~N}$ & $117.396 \mathrm{~W}$ & 39.55 & 3.1 & \\
\hline $1970 \mathrm{Jul} 11$ & $10: 24$ & $48.204 \mathrm{~N}$ & $12 \mathrm{i} .355 \mathrm{~W}$ & 0.05 & 3.0 & \\
\hline 1970 Aug 23 & $11: 11$ & $46.746 \mathrm{~N}$ & $119.348 \mathrm{~W}$ & 2.96 & 3.4 & \\
\hline 1970 Sep 11 & $02: 20$ & $46.654 \mathrm{~N}$ & $120.404 W$ & $18.15^{(\mathrm{c})}$ & 3.5 & \\
\hline 1970 Oct 01 & $11: 46$ & $46.756 \mathrm{~N}$ & $119.378 \mathrm{~W}$ & $4.52^{(b)}$ & 3.0 & \\
\hline 1970 Oct 02 & $15: 56$ & $46.757 \mathrm{~N}$ & $119.373 \mathrm{~W}$ & 4.01 & 3.4 & \\
\hline 1970 Oct 19 & $07: 15$ & $46.886 \mathrm{~N}$ & $117.569 \mathrm{~W}$ & 15.53 & 3.2 & \\
\hline 1970 Nov 06 & $18: 15$ & $46.687 \mathrm{~N}$ & $118.872 \mathrm{~W}$ & 2.42 & 3.1 & \\
\hline 1970 Nov 29 & $02: 15$ & $47.412 \mathrm{~N}$ & $121.421 \mathrm{~W}$ & $14.94(d)$ & 3.3 & \\
\hline 1971 Jan 26 & $10: 17$ & $46.901 \mathrm{~N}$ & $119.569 \mathrm{~W}$ & 4.36 & 3.2 & \\
\hline 1971 May 22 & $15: 57$ & $47.790 \mathrm{~N}$ & $118.953 \mathrm{~W}$ & 35.08 & 3.3 & \\
\hline $1971 \mathrm{Jul} 13$ & $23: 29$ & $45.024 \mathrm{~N}$ & $117.962 \mathrm{~W}$ & 17.62 & 3.5 & \\
\hline 1971 Aug 18 & $23: 44$ & $47.649 \mathrm{~N}$ & $120.146 \mathrm{~W}$ & 13.23 & 3.2 & \\
\hline 1971 Oct 25 & 18: 52 & $46.708 \mathrm{~N}$ & $119.550 \mathrm{~W}$ & 3.99 & 3.8 & \\
\hline 1971 Nov 23 & $02: 12$ & $48.166 \mathrm{~N}$ & $121.427 \mathrm{~W}$ & 24.81 & 4.1 & \\
\hline 1972 Jun 19 & $23: 57$ & $48.063 \mathrm{~N}$ & $121.399 \mathrm{~W}$ & 2.34 & 3.2 & \\
\hline 1973 Sep 04 & $17: 56$ & $48.233 \mathrm{~N}$ & $121.227 \mathrm{~W}$ & 4.87 & 3.7 & \\
\hline $1973 \mathrm{Dec} 20$ & $01: 08$ & $46.867 \mathrm{~N}$ & $119.357 \mathrm{~W}$ & 3.31 & 4.4 & \\
\hline $1974 \mathrm{Apr} 20$ & $03=00$ & $46.716 \mathrm{~N}$ & $121.476 \mathrm{~W}$ & 5.55 & 4.7 & \\
\hline 1974 Apr 21 & $14: 08$ & $46.691 \mathrm{~N}$ & $121.430 \mathrm{~W}$ & 4.82 & 3.5 & \\
\hline 1975 Jun 15 & $17: 51$ & $46.234 \mathrm{~N}$ & $119.113 \mathrm{~W}$ & 1.74 & 3.1 & \\
\hline 1975 Jun 28 & $16: 33$ & $46.105 \mathrm{~N}$ & $119.704 \mathrm{~W}$ & 9.34 & 3.3 & \\
\hline 1975 Jun 28 & $22: 17$ & $46.099 \mathrm{~N}$ & $119.706 \mathrm{~W}$ & 10.97 & 3.8 & \\
\hline $1975 \mathrm{Jul} 01$ & $05: 28$ & $45.605 \mathrm{~N}$ & 120 & 15.32 & 3.6 & \\
\hline $1975 \mathrm{Jul} 07$ & $20: 4$ & $45.951 \mathrm{~N}$ & 118.2 & $8.04(c)$ & 3.2 & \\
\hline 1975 Sep 18 & $12: 19$ & $47.811 \mathrm{~N}$ & $118.258 \mathrm{~W}$ & 6.52 & 3.5 & \\
\hline 1976 Mar 29 & $12: 36$ & $45.122 \mathrm{~N}$ & 12 & 15.00 & 3.0 & \\
\hline 1976 Apr 02 & $20:$ & $45.136 \mathrm{~N}$ & 120 & 15.00 (b) & 3.2 & (e) \\
\hline 1976 Apr 06 & $17: 56$ & $45.155 \mathrm{~N}$ & $120.802 \mathrm{~W}$ & 15.00 (b) & 3.2 & (e) \\
\hline 1976 Apr 06 & 23: & $45.097 \mathrm{~N}$ & & 15.0 & 3.4 & (e) \\
\hline 1976 Apr 08 & 10: & 45.15 & & 15.00 (b) & 3.8 & (e) \\
\hline 1976 Apr 09 & $09: 11$ & $45.208 \mathrm{~N}$ & $120.887 \mathrm{~W}$ & 15.00 (b) & 3.5 & (e) \\
\hline 1976 Apr 13 & 00 & 45.1 & 121 & 15.00 (b) & 3.3 & (e) \\
\hline 1976 Apr 13 & $00: 47$ & $45.076 \mathrm{~N}$ & $120.859 \mathrm{~W}$ & $15.00^{(b)}$ & 4.6 & \\
\hline 1976 Apr 13 & $01: 20$ & $45.121 \mathrm{~N}$ & $120.894 \mathrm{~W}$ & $15.00^{(b)}$ & 3.4 & (e) \\
\hline 1976 Apr 13 & $13: 29$ & $45.147 \mathrm{~N}$ & $120.860 \mathrm{~W}$ & 15.00 (b) & 3.1 & (e) \\
\hline 1976 Apr 17 & $02: 11$ & $45.159 \mathrm{~N}$ & $120.847 \mathrm{~W}$ & $15.00^{(b)}$ & 4.0 & \\
\hline 1976 May 15 & $13: 04$ & $47.711 \mathrm{~N}$ & $120.062 \mathrm{~W}$ & 8.04 & 3.1 & \\
\hline 1976 Jun 15 & $01: 01$ & 46.46 & 117.7 & $0.02^{(b)}$ & 3.0 & \\
\hline 1976 Jun 15 & 09: & $47.625 \mathrm{~N}$ & $120.327 \mathrm{~W}$ & 0.75 & 3.0 & \\
\hline 197 & 17: & 46. & 118 & $0.02^{(D)}$ & 3.1 & \\
\hline 1976 Aug $3 c$ & $16: 34$ & $7.654 \mathrm{~N}$ & $120.200 \mathrm{~W}$ & 5.50 & 3.1 & \\
\hline
\end{tabular}


TABLE 3.2. (contd)

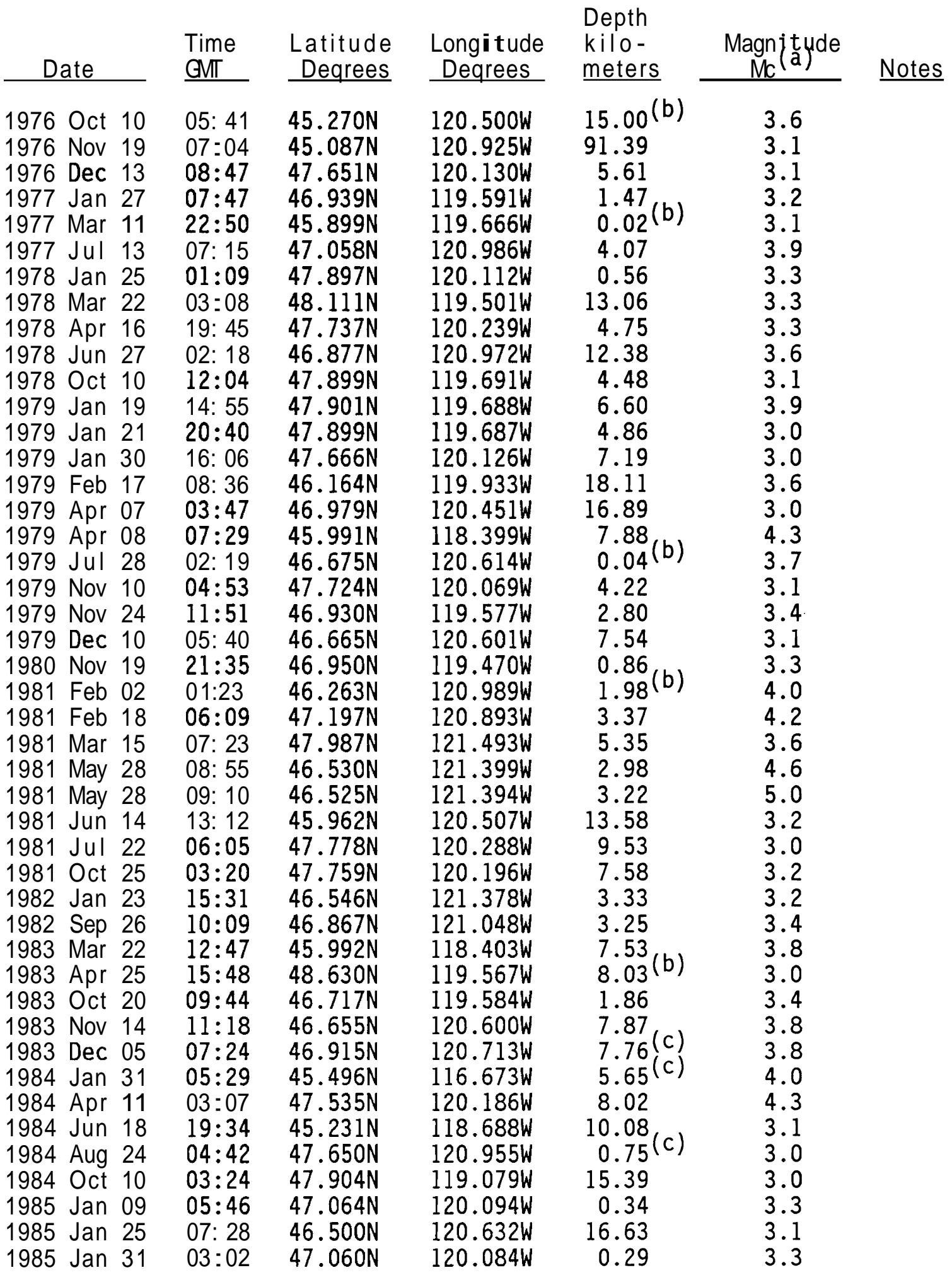


TABLE 3.2. (contd)

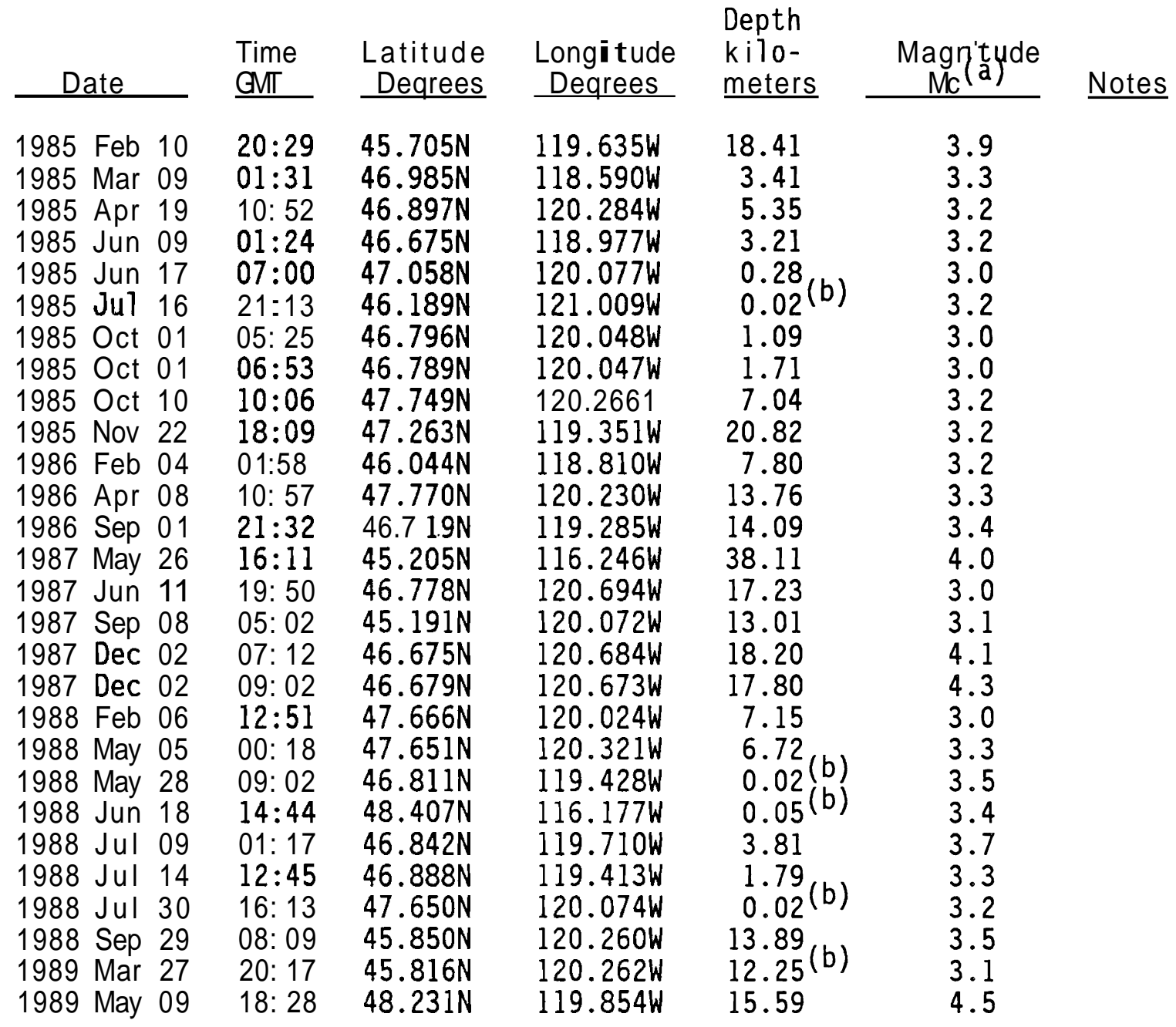
(a) Mc - Coda-length magnitude. Approximately equals local Richter Magnitude, ML.
(b) Depth fixed (depth less than $0.05 \mathrm{~km}$ or unstable within $0.2 \mathrm{~km}$ ).
(c) Maximum iterations (24) exceeded (last location used).
(d) Maximum iterations (24) exceeded while depth fixed (last location used).
(e) Location and magnitude determined by Couch et al. (1976). 


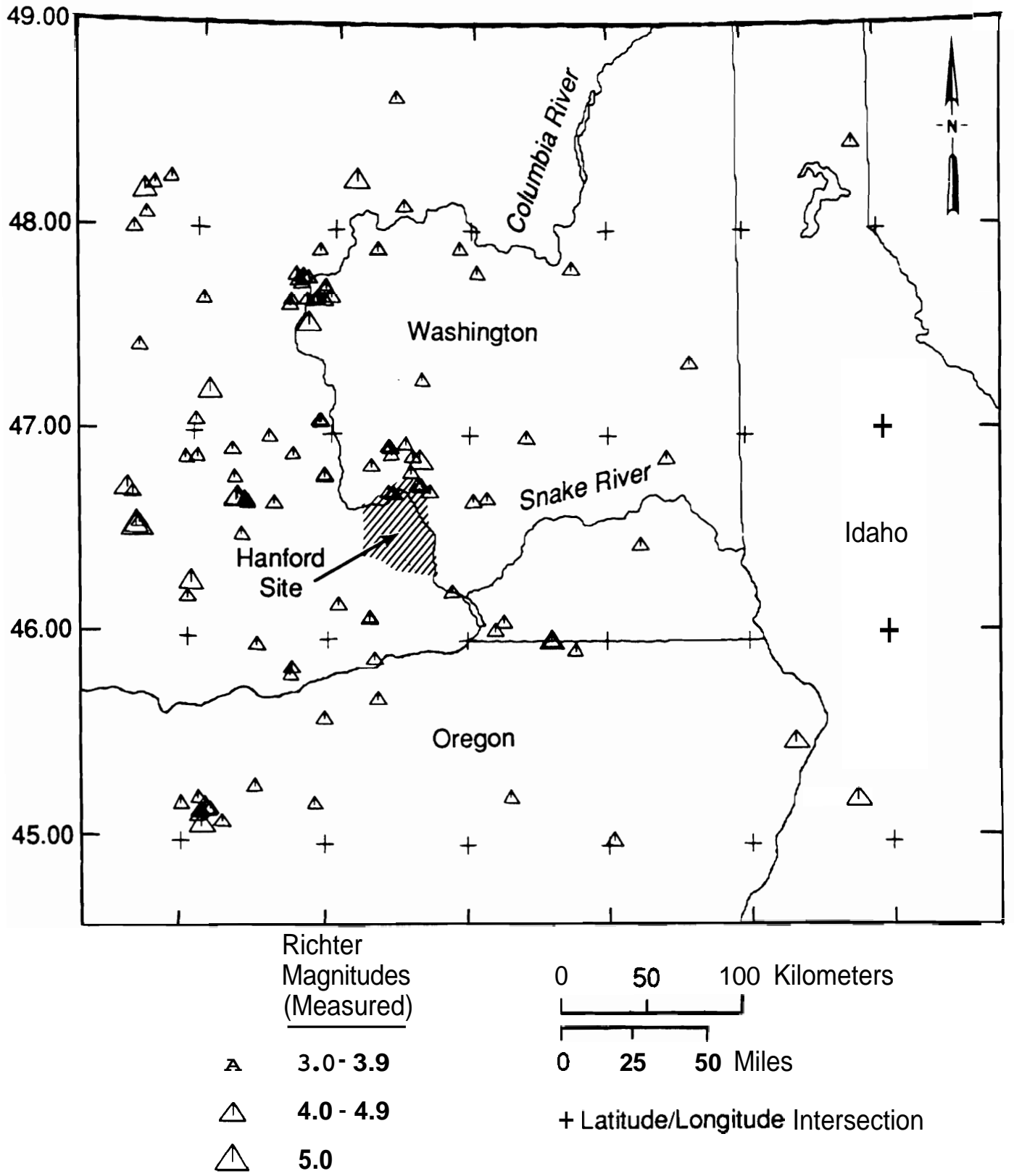

FIGURE 3.9. Recent Seismic it y of the Columbia Plateau and Surrounding Areas. All Earthquakes Between March 23, 1969 and 1989 with a Magnitude of 3 or Larger are Shown (see Table 3.2). 
east of the Hanford Site is a region of concentrated earthquake swarm activity, but earthquake swarms have also occurred in several locations within the Hanford Site. Earthquakes in a swarm tend to gradually increase and decay in frequency of events, and there is usually no one outstanding large event within the sequence. These earthquake swarms occur at shallow depths, with $75 \%$ of the events located at depths less than $4 \mathrm{~km}$. Each earthquake swarm typically lasts several weeks to months, consists of several to 100 or more earthquakes, and is clustered in an area about 5 to $10 \mathrm{~km}$ in lateral dimension. Often, the longest dimension of the swarm area is elongated in an east-west direction. However, detai led locations of swarm earthquakes indicate that the events occur on fault planes of variable orientation.

Earthquakes in the central Columbia Plateau also occur to depths of about $30 \mathrm{~km}$. These deeper earthquakes are less clustered and occur more often as single, isolated events. Based on seismic refraction surveys in the region, the shallow earthquake swarms occur in the Columbia River Basalts, and the deeper earthquakes occur in crustal layers below the basalts (Catchings and Mooney 1988; Glover 1985).

The spatial pattern of seismicity in the central Columbia Plateau suggests an association of the shallow swarm activity with the east-west oriented Saddle Mountains anticline. However, this association is complex, and the earthquakes do not delineate a fault plane that would be consistent with the faulting observed on this structure.

Earthquake focal mechanisms in the central Col umbi a Plateau general ly indicate reverse faulting on east-west planes, consistent with a north-south directed maximum compressive stress and with the formation of the east-west oriented anticlinal folds of the Yakima Fold Belt (Rohay 1987). However, earthquake focal mechanisms indicate faulting on a variety of fault-plane orientations.

Earthquake focal mechanisms along the western margin of the Columbia Plateau also indicate north-south compression, but here the minimum compressive stress is oriented east-west, resulting in strike-slip faulting (Rohay 1987). Geologic studies indicate an increased component of strike-slip 
faulting in the western portion of the Yakima Fold Belt. Earthquake focal mechanisms in the Milton-Freewater region to the southeast indicate a different stress field; one that has east-west directed maximum compression instead of north-south.

Estimates for the earthquake potential of structures and zones in the central Columbia Plateau have been developed during the licensing of nuclear power plants at the Hanford Site. The NAC (1982), in its review of the operating license application for the WPPSS WNP-2, concluded that four earthquake sources should be considered for the purpose of seismic design: 1) the Rattlesnake-Wallula alignment, 2) Gable Mountain, 3) a floating earthquake in the tectonic province, and 4) a swarm area.

For the Rattlesnake-Wallula Alignment, which passes along the southwest boundary of the Hanford Site, the NRC estimated a maximuni magnitude of 6.5. For Gable Mountain, an east-west structure that passes through the northern portion of the Hanford Site, a maximum magnitude of 5.0 was estimated. These estimates were based on the inferred sense of slip, the fault length, and/or the fault area. The floating earthquake for the tectonic province was developed from the largest event located in the Columbia Plateau, the magnitude 5.75 Milton-Freewater earthquake. The maximum swarm earthquake for the purpose of WNP-2 seismic design was a magnitude 4.0 event, based on the maximum swarm earthquake in 1973. (The NAC concluded that the actual magnitude of this event was smaller than estimated previously.)

The seismic design of WNP-2 is based upon a Safe-Shutdown Earthquake (SSE) of $0.25 \mathrm{~g}$. A probabilistic seismic exposure analysis was used to determine an annual probability of $1 \times 10^{-4}$ for excedance of $0.25 \mathrm{~g}$ (WPPSS 1981). For the WNP-2 site, potential earthquakes associated with the Gable Mountain structure dominated the excedance probability calculations compared to other potential earthquake sources that were considered.

\subsection{SOILS}

Hajek (1966) lists and describes 15 different soil types on the Hanford site. The soil types vary from sand to silty and sandy loam. These are 
listed and briefly described in Table $\mathbf{3 . 3}$ and shown in Figure 3.10. Various classifications including 1 and use classification are also given in Hajek (1966) .

Hajek defines the thickness of the soil as the depth to which the roots of the native plants extend (i.e., several meters for vegetation at the Hanford Site).

Efforts to obtain reliable estimates of hydraulic conductivity for unsaturated Hanford soils have been underway for several years and are presently continuing. Estimates to date for sand/sandy soils fall generally

within the range of $10^{-4}$ to $10^{-6} \mathrm{~cm} / \mathrm{sec}$, depending on the soil type; vegetation, if any; and depth (Gee et al. 1989).

The erosion potential of the Hanford surficial material is low because of the relatively flat slopes and the low annual precipitation.

\subsection{NATURAL RADIOACTIVITY}

The natural radioactivity background is composed of naturally-occurring, long-lived radioactive nuclides and their radioactive daughters, direct radiation from cosmic radiation, and nuclides formed by interaction of stable elements with high-energy radiation (usually lighter elements in the upper atmosphere). Superimposed upon this naturally occurring background radiation is the residual fallout from atmospheric weapons testing. At Hanford, some indications of small, naturally-occurring uranium and thorium sources are present, as radon-222 and radon-220 progeny, during atmospheric inversions (ERDA 1975). The arid climate tends to minimize the amount of fallout nuclides accumulated in local soils. Table $\mathbf{3 . 4}$ shows the radionuclide concentrations in Hanford soils for 1988 (PNL 1989a). 
TABLE 3.3. Soil Types on the Hanford Site (Hajek 1966)

Name and (symbol)

Ritzville Silt Loam (RI)

Rupert Sand (Rp)

Hezel Sand (He)

Koehler Sand (Kf)

Burbank Loamy Sand (Ba)

Kiona Si $7 t$ Loam (Ki)

Warden Silt Loam (Wa)
Description

Dark colored silt loam soils midway up the slopes of the Rattlesnake Hills. Developed under bunch grass from silty wind-laid deposits mixed with small amounts of volcanic ash. Characteristically $>150$ am deep, but bedrock may occur at $<150 \mathrm{~cm}$ but $>75 \mathrm{~cm}$.

One of the most extensive soils on the Hanford Site. Brown-to-grayish brown coarse sand grading to dark grayish brown at about $90 \mathrm{~cm}$. Developed under grass, sagebrush, and hopsage in coarse sandy alluvial deposits that were mantled by windblown sand. Hummocky terraces and dune-like ridges.

Similar to Rupert sand; however, a laminated grayish brown strongly calcareous silt loam subsoil is usually encountered within $100 \mathrm{~cm}$ of the surface. Surface soil is very dark brown and was formed in wind-blown sands that mantled lake-laid sediments.

Similar to other sandy soils on the Hanford Site. Developed in a wind-blown sand mantle. Differs from other sands in that the sand mantles a limesilica cemented layer "hardpan." Very dark grayish brown surface layer is somewhat darker than Rupert sand. Calcareous subsoil is usually dark grayish brown at about $45 \mathrm{~cm}$.

Dark-colored, coarse-textured soi 1 underlain by gravel. Surface soil is usually about $40 \mathrm{~cm}$ thick but can be $75 \mathrm{~m}$ thick. Gravel content of subsoil ranges from 20 to $80 \%$.

Occupies steep slopes and ridges. Surface soil is very dark grayish brown and about 10 om thick.

Dark brown subsoil contains basalt fragments $30 \mathrm{~cm}$ and larger in diameter. Many basalt fragments found in surface layer. Basalt rock outcrops present. A shallow stony soil normally occurring in association with Ritzville and Warden soils.

Dark grayish brown soil with a surface layer usually 23 am thick. Silt loam subsoil becomes strongly calcareous at about $50 \mathrm{~cm}$ and becomes lighter colored. Granitic boulders are found in many areas. Usually >150 am deep. 
TABLE 3.3. (contd)

Name and (symbol)

Ephrata Sandy Loam (E1)

Ephrata Stony Loam (Eb)

Scootney Stony Silt

Loam $(\mathrm{Sc})$

Pasco Silt Loam (P)

Esquatzel Silt Loam (Qu)

Riverwash (Rv)

Dune Sand (D)

Lickskiller Silt Loam (Ls)
Description

Surface is dark colored and subsoil is dark grayish brown medium-textured soil underlain by gravelly material, which may continue for many feet. Level topography.

Similar to Ephrata sandy loam. Differs in that many large hummocky ridges are presently made up of debris released from melting glaciers. Areas between hummocks contain many boulders several feet in diameter.

Developed along the north slope of Rattlesnake Hills, usually confined to floors of narrow draws or small fan-shape areas where draws open onto plains. Severely eroded with numerous basaltic boulders and fragments exposed. Surface soil is usually dark grayish brown grading to grayish brown in the subsoil.

Poorly drained very dark grayish brown soil formed in recent alluvial material. Subsoil is variable, consisting of stratified layers. Only small areas found on Hanford Site located in low areas adjacent to the Columbia River.

Deep dark brown soil formed in recent alluvium derived from loess and lake sediments. Subsoil grades to dark grayish brown in many areas but color and texture of the subsoil is variable due to the stratified nature of the alluvial deposits.

Wet, periodically flooded areas of sand, gravel, and boulder deposits that make up overflowed islands in the Columbia river and adjacent land.

Miscellaneous land type that consists of hills or ridges of sand-sized particles drifted and piled up by wind and are either actively shifting or so recently fixed or stabilized that no soil horizons have developed.

Occupies ridge slopes of Rattlesnake Hills and slopes $>765$ m elevation. Similar to Kiona series except surface soils are darker. Shallow over basalt bedrock, with numerous basalt fragments throughout the profile. 


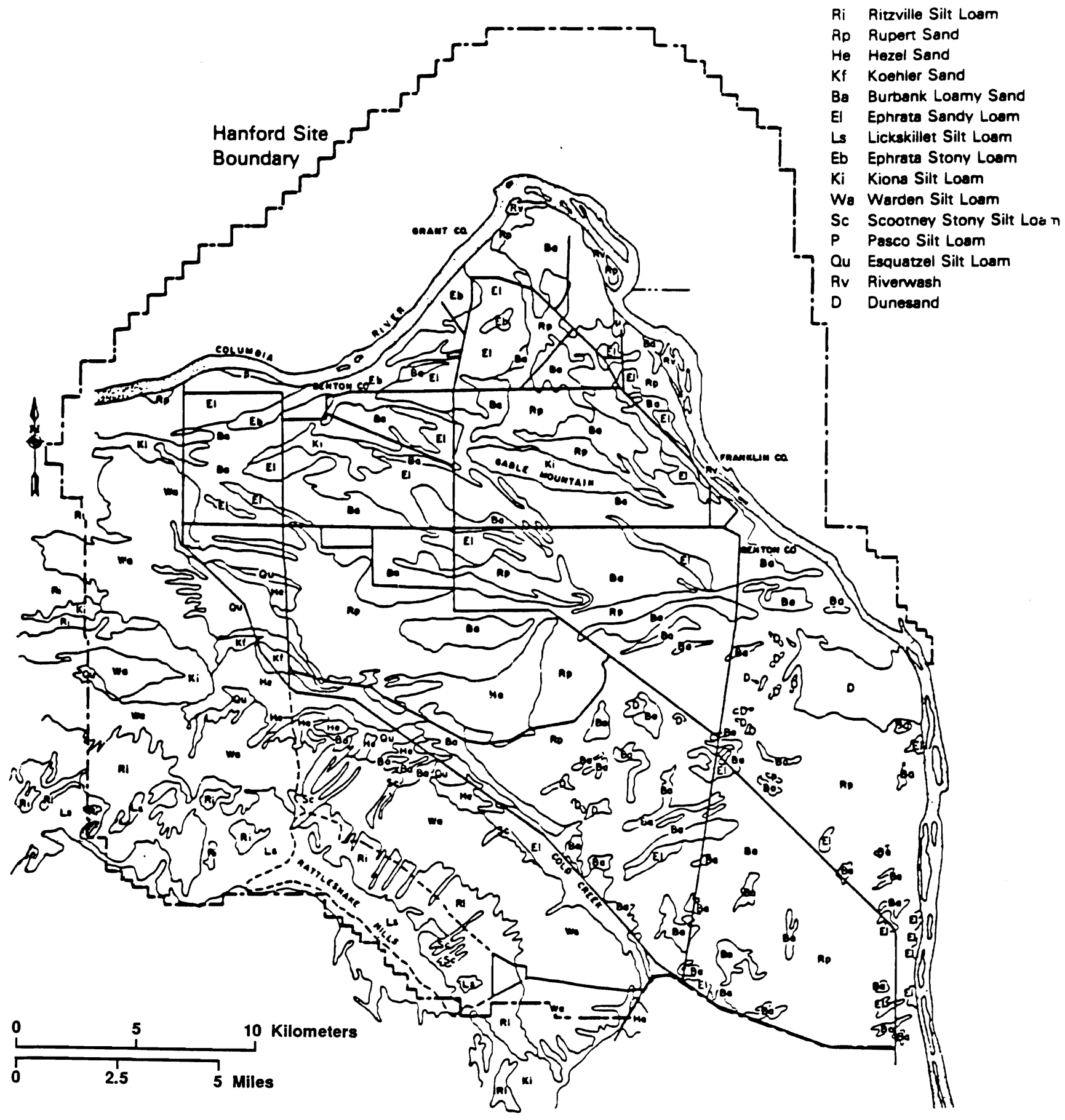

FIGURE 3.10. Soil Map of the Hanford Site (Hajek 1966) 
TABLE 3.4. Radionuclides Present in Hanford Soils in 1988 (PNL 1989a)

\begin{tabular}{|c|c|c|c|}
\hline \multirow[b]{2}{*}{ Radionuclide } & \multicolumn{3}{|c|}{$\mathrm{pCi} / \mathrm{g}$ dry weight ${ }^{(a)}$} \\
\hline & Maximum & Minimm & Average \\
\hline Strontiun-90 & $7.7 \times 10^{-1} \pm 2.0 \times 10-2$ & $7.0 \times 10^{-2} \pm 1.0 \times 10^{-2}$ & $3.1 \times 10^{-1} \pm 1.3 \times 10^{-1}$ \\
\hline Cesium-137 & $26.0 \pm 1.0^{-1}$ & $4.0 \times 10^{-2} \pm 2.0 \times 10^{-2}$ & $2.9 \pm 3.2$ \\
\hline Plutoniun-239, 240 & $6.7 \times 10^{-1} \pm 1.2 \times 10^{-1}$ & $1.0 \times 10^{-3} \pm 1.0 \times 10^{-3}$ & $1.0 \times 10^{-1} \pm 1.1 \times 10^{-1}$ \\
\hline Uranium (total) & $1.2 \pm 3.0 \times 10^{-1}$ & $4.4 \times 10^{-1} \pm 4.6 \times 10^{-1}$ & $7.4 \times 10^{-1} \pm 1.5 \times 10^{-1}$ \\
\hline
\end{tabular}

(a) Results \pm two sigma counting errors. 


\subsection{WAIR RESOURCES}

The affected hydrologic environment of the Hanford Site consists of those surface waters and subsurface waters, or groundwater, within and around the Hanford Site boundary.

\subsection{HANFORD HYDROLOGY}

Primary surface waters associated with the Hanford Site are the Columbia and Yakima Rivers. Other nearby surface waters of significance are the Snake and Walla Walla Rivers. The Columbia River is the only river within the Hanford Site. There are no perennial streams. West Lake, about 4 ha in size and less than $1 \mathrm{~m}$ deep, is the only natural lake within the Hanford Site (DOE 1988). Several surface ponds and ditches are present and are generally associated with fuel and waste processing activities (Figure 4.1).

Groundwater under the Hanford Site occurs under unconfined and confined conditions, The unconfined aquifer is contained within the glaciofluvial sands and gravels and within the Ringold Formation. The confined aquifers consist of sedimentary interbeds and/or interflow zones that occur between dense basalt flows in the Columbia River Basalt Group.

\subsubsection{Surface Hydroloqy}

The Pasco Basin occupies about 4,900 $\mathrm{km}^{2}$ and is located centrally within the Columbia Basin. Elevations within the Pasco Basin are generally lower than other parts of the plateau and surface drainage enters it from other basins. Within the Pasco Basin, the Columbia River is joined by major tributaries--the Yakima, Snake, and Walla Walla Rivers. Total estimated precipitation over the Pasco Basin is about $9 \times 10^{8} \mathrm{~m}^{3}$ annually, averaging less than $20 \mathrm{~cm} / \mathrm{yr}$. Mean annual runoff from the basin is estimated to be less than $3.1 \times 10^{7} \mathrm{~m}^{3} / \mathrm{yr}$, or approximately $3 \%$ of the total precipitation. The basin-wide runoff coefficient is zero for all practical purposes. The remaining precipitation is assumed to be lost through evapotranspiration with a small component (perhaps less than 1\%) recharging the groundwater system (DOE 1988). 


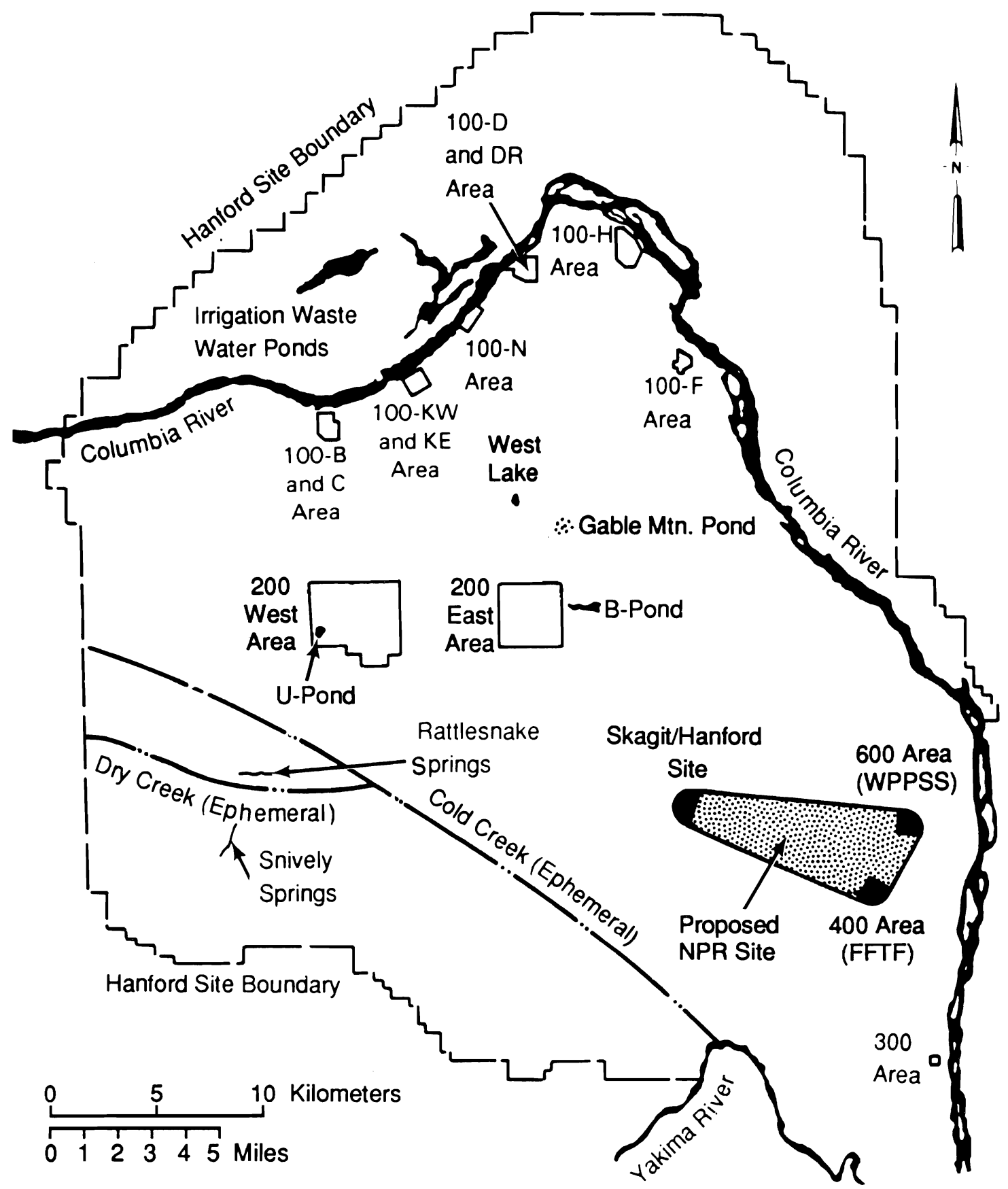

FIGURE 4.1. Surface Water Bodies, Including Ephemeral Streams on the Hanford Site (DOE 1987) 


\subsubsection{Rivers/Streams}

Approximately two-thirds of the Hanford Site is part of the Columbia River drainage system, and surface runoff from this area would flow directly into the Columbia River along the Hanford Reach which enters from the upstream end of Lake Wallula. The flow has been inventoried and described in detail by the U.S. Army Corps of Engineers (DOE 1986). Flow along this reach is controlled by the Priest Rapids Dam. Several drains and intakes are also present along this reach. These include irrigation outfalls from the Columbia Basin Irrigation Project and Hanford Site intakes for the onsite water export system.

Recorded flow rates of the Columbia River have ranged from 4,500 to $18,000 \mathrm{~m}^{3} / \mathrm{s}$ during the runoff in spring and summer, and from 1,000 to $4,500 \mathrm{~m}^{3} / \mathrm{s}$ during the low flow period of 1ate summer and winter (Jamison 1982). The average annual Columbia River flow in the Hanford Reach, based on 65 years of record, is about $3,400 \mathrm{~m}^{3} / \mathrm{s}$ (DOE 1987). A minimum flow of about $1,020 \mathrm{~m}^{3} / \mathrm{s}$ is maintained along the Hanford Site. Normal river elevations within the site range from $120 \mathrm{~m}$ above ML where the river enters the site near Vernita to $104 \mathrm{~m}$ above $\mathbf{M L}$ where it leaves the site near the 300 Area.

A network of dams and multipurpose water resources projects is located along the course of the Columbia River. The principal dams are shown in Figure 4.2. Storage behind Grand Coulee Dam, combined with storage upstream in Canada, make a total of $3.1 \times 10^{10} \mathrm{~m}^{3}$ of usable storage to regulate the Columbia River for power, flood control, and irrigation of land within the Col umbi a Basin Project.

The Yakima River, bordering the southern portion of the Hanford Site, has a low annual flow when compared with the Columbia River. For a period of 57 years of record, the average annual flow of the Yakima River is about $104 \mathrm{~m}^{3} / \mathrm{s}$ with monthly maximum and minimum flows of $490 \mathrm{~m}^{3} / \mathrm{s}$ and $4.6 \mathrm{~m}^{3} / \mathrm{s}$, respectively. Approximately one-third of the Hanford Site is drained by the Yakima River system.

Cold Creek and its tributary, Dry Creek, are ephemeral streams within the Yakima River drainage system along the southern boundary of the Hanford Site (Figure 4.1). Both streams drain areas to the west of the Hanford Site 


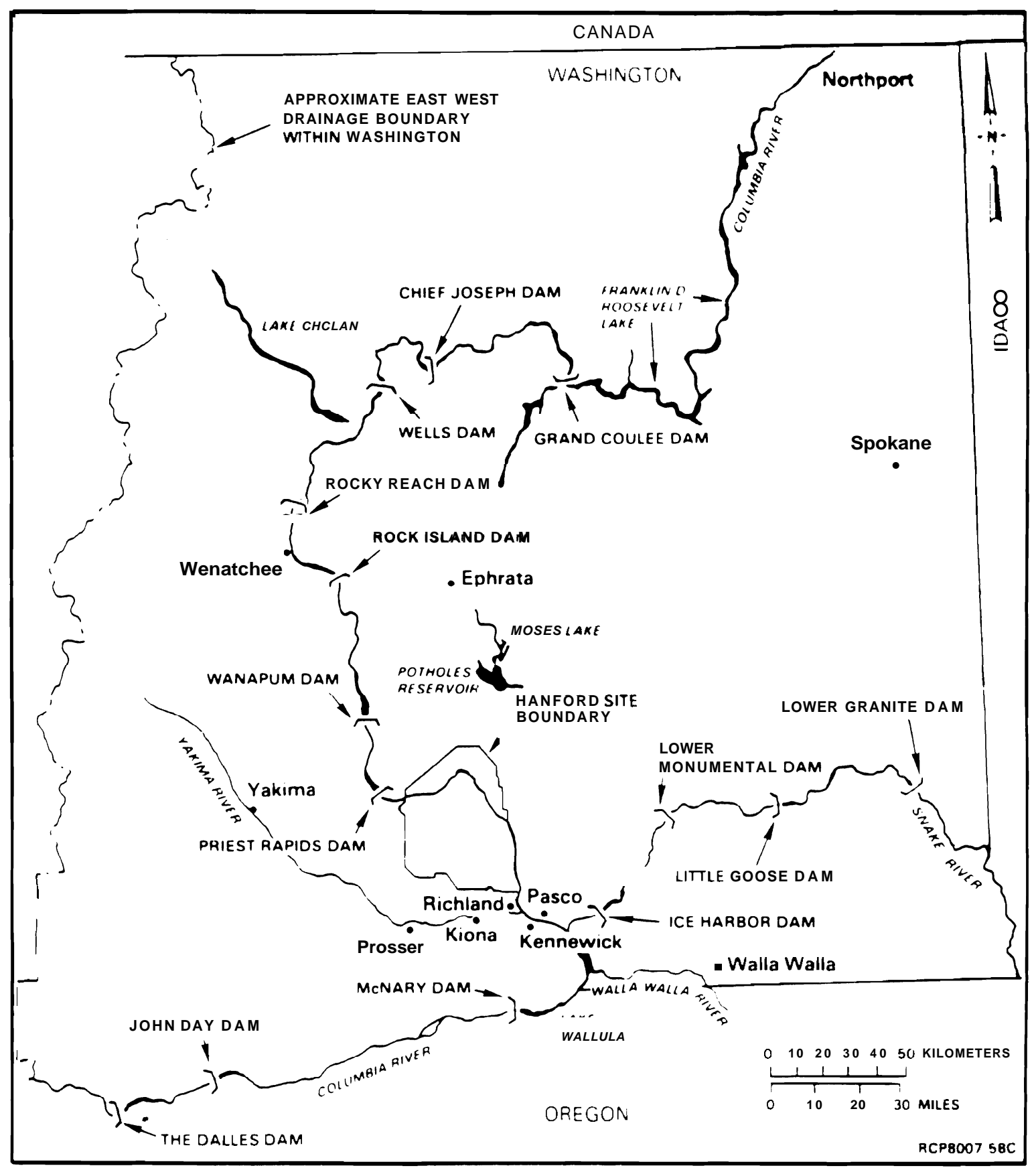

\section{FIGURE 4.2. Locations of Principal Dams Within the Columbia Plateau Study Area (DOE 1988)}


and cross the southwestern part of the site toward the Yakima River. Surface flow, when it occurs, infiltrates and disappears into the surface sediments in the western part of the site. Rattlesnake Springs, located on the western part of the site, forms a small surface stream that flows for about $3 \mathrm{~km}$ before disappearing into the ground.

4.1.1.1.1 Flooding. The Washington State portion of the Columbia Plateau has been subdivided into water resource inventory areas that correspond to component watersheds of the Columbia River drainage (DOE 1988). Leonhart (1979), for the purpose of regional hydrologic assessment, proposed division of the Washington State portion of the Columbia Plateau into six subbasins on the basis of both structural and drainage characteristics, shown in Figure 4.3. The Hanford Site is located within the Pasco Basin hydrologic basin. Surface water drainage from the surrounding five basins (with the exception of the southern part of the Horse Heaven Basin) enters the Pasco Basin.

Large Columbia River floods have occurred in the past (DOE 1987) but the likelihood of recurrence of large scale flooding has been reduced by the construction of several flood control/water storage dams upstream of the site. Major floods on the Columbia River are typically the result of rapid melting of the winter snowpack over a wide area augmented by above-normal precipitation. The maximum historical flood on record occurred June 7, 1894, with a peak discharge at the Hanford Site of $21,000 \mathrm{~m}^{3} / \mathrm{s}$. The largest recent flood took place in 1948 with an observed peak discharge of $20,000 \mathrm{~m}^{3} / \mathrm{s}$ at the Hanford Site. The probability of flooding at the magnitude of the 1894 and 1948 floods has been greatly lowered because of upstream regulation by dams.

There are no Federal Emergency Management Agency (FEMA) flood plain maps for the Hanford reach of the Columbia River. FEMA only maps developing areas, and the Hanford reach is specifically excluded.

There have been fewer than 20 major floods on the Yakima River since 1862 (DOE 1986). The most severe floods occurred in November 1906, December 1933, and May 1948. Discharge magnitudes at Kiona, Washington, were 1,870, 1,900 , and $1,050 \mathrm{~m}^{3} / \mathrm{s}$, respectively. The recurrence intervals for the 1933 


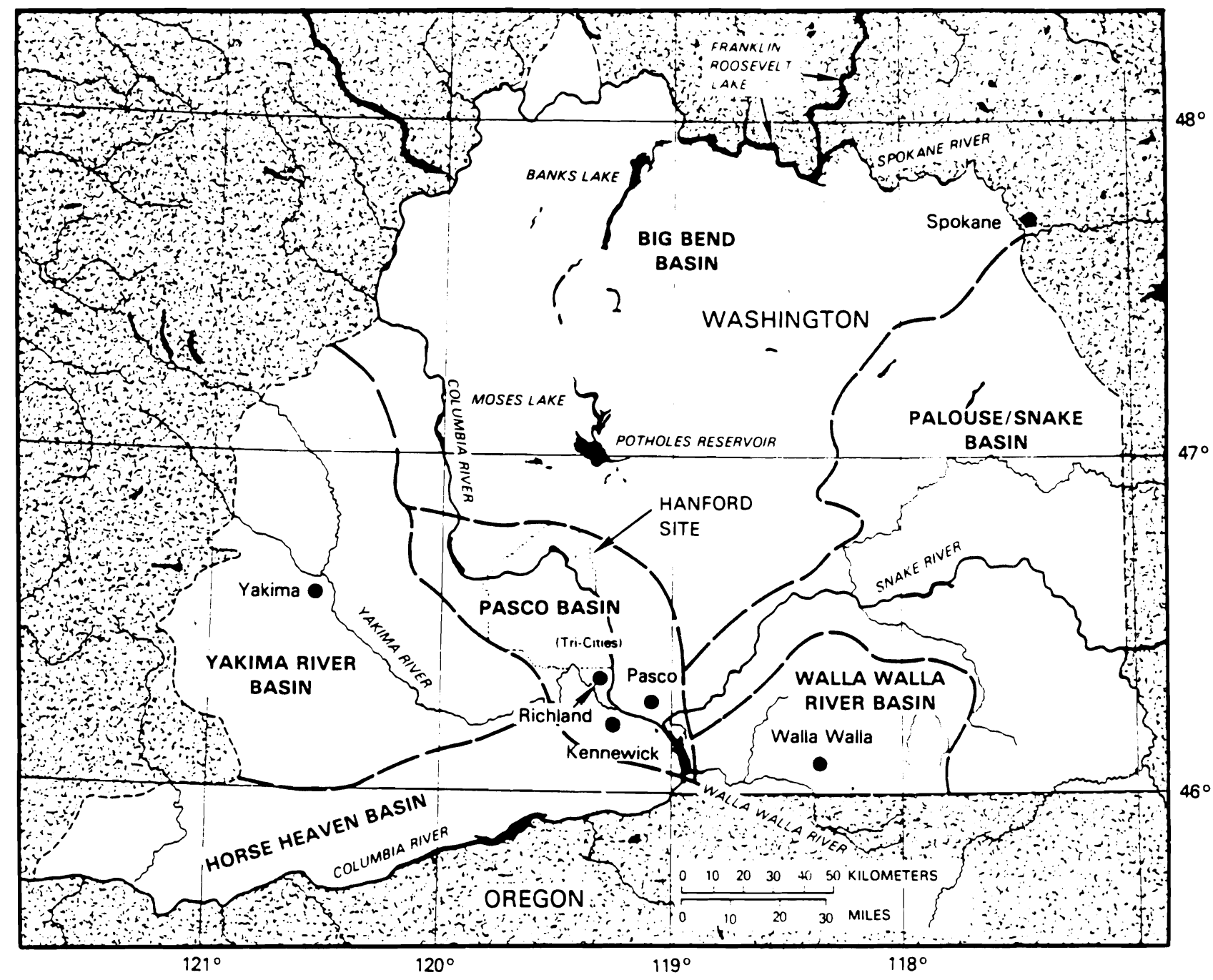

FIGURE 4.3. Hydrologic Basins Designated for the Washington State Portion of the Columbia Plateau (DOE 1988)

and 1948 floods are estimated at 170 and $\mathbf{3 3}$ years respectively. The development of irrigation reservoirs within the Yakima River Basin has considerably reduced the flood potential of the river. Flooded areas from the 100-year flood could extend into the southern section of the Hanford Site, but the Yakima River upstream is physically separated from the Hanford Site by Rattlesnake Mountain, which would prevent major flooding of the Hanford Site.

Evaluation of flood potential is conducted in part through the concept of the probable maximum flood, which is determined from the upper limit of precipitation falling on a drainage area and other hydrologic factors, such 
as antecedent moisture conditions, snowmelt, and tributary conditions that could result in maximum runoff. The probable maximum flood for the Columbia River below Priest Rapids Dm has been calculated to be $40,000 \mathrm{~m}^{3} / \mathrm{s}$. The flood plain associated with the probable maximum flood is shown in Figure 4.4. This flood would inundate portions of the 100 Areas located adjacent to the Columbia River, but the central portion of the Hanford Site would remain unaffected (DOE 1986).

Potential dam failures on the Columbia River have been evaluated. Upstream failures could arise from a number of causes, with the magnitude of the resulting flood depending on the degree of breaching at the dam. The U.S. Army Corps of Engineers evaluated a number of scenarios on the effects of failures of Grand Coulee Dam, assuming flow conditions on the order of $11,000 \mathrm{~m}^{3} / \mathrm{s}$. The discharge resulting from a $50 \%$ breach caused by the direct hit of a nuclear weapon at the outfall of Grand Coulee Dm was determined to be $600,000 \mathrm{~m}^{3} / \mathrm{s}$. In addition to the areas inundated by the probable maximum flood, the remainder of the 100 Areas, the 300 Area, and nearly all of Richland, Washington, would be flooded (DOE 1986). N determinations were made for breaches greater than 50\% of Grand Coulee, for failures of dams upstream or for associated failures downstream of Grand Coulee. The 50\% scenario was believed to represent the largest, realistically conceivable flow resulting from a natural or human-induced breach (DOE 1986). The possibility of a landslide resulting in river blockage and flooding along the Columbia River has also been examined for an area bordering the east side of the river upstream from the city of Richland. The possible landslide area considered was the 75-m high bluff generally known as White Bluffs. Calculations were made for an $8 \times 10^{5}-\mathrm{m}^{3}$ landslide volume with a concurrent flood flow of $17,000 \mathrm{~m}^{3} / \mathrm{s}$ (a 200-year flood) resulting in a flood wave crest elevation of $122 \mathrm{~m}$ above MSL Areas inundated upstream from such a landslide event would be similar to those shown in Figure 4.4 (DOE 1986).

The NRC has accepted a hypothetical breach of Grand Coulee Dam and the subsequent failure of all downstream dams as yielding the controlling flood levels for Hanford. Based on these criteria, the NRC concluded that the predicted flood level of about $130 \mathrm{~m}$ above ME at the WPPSS WNP-2 site would present no risk to the safe operation of the plant. The potential NPR site 


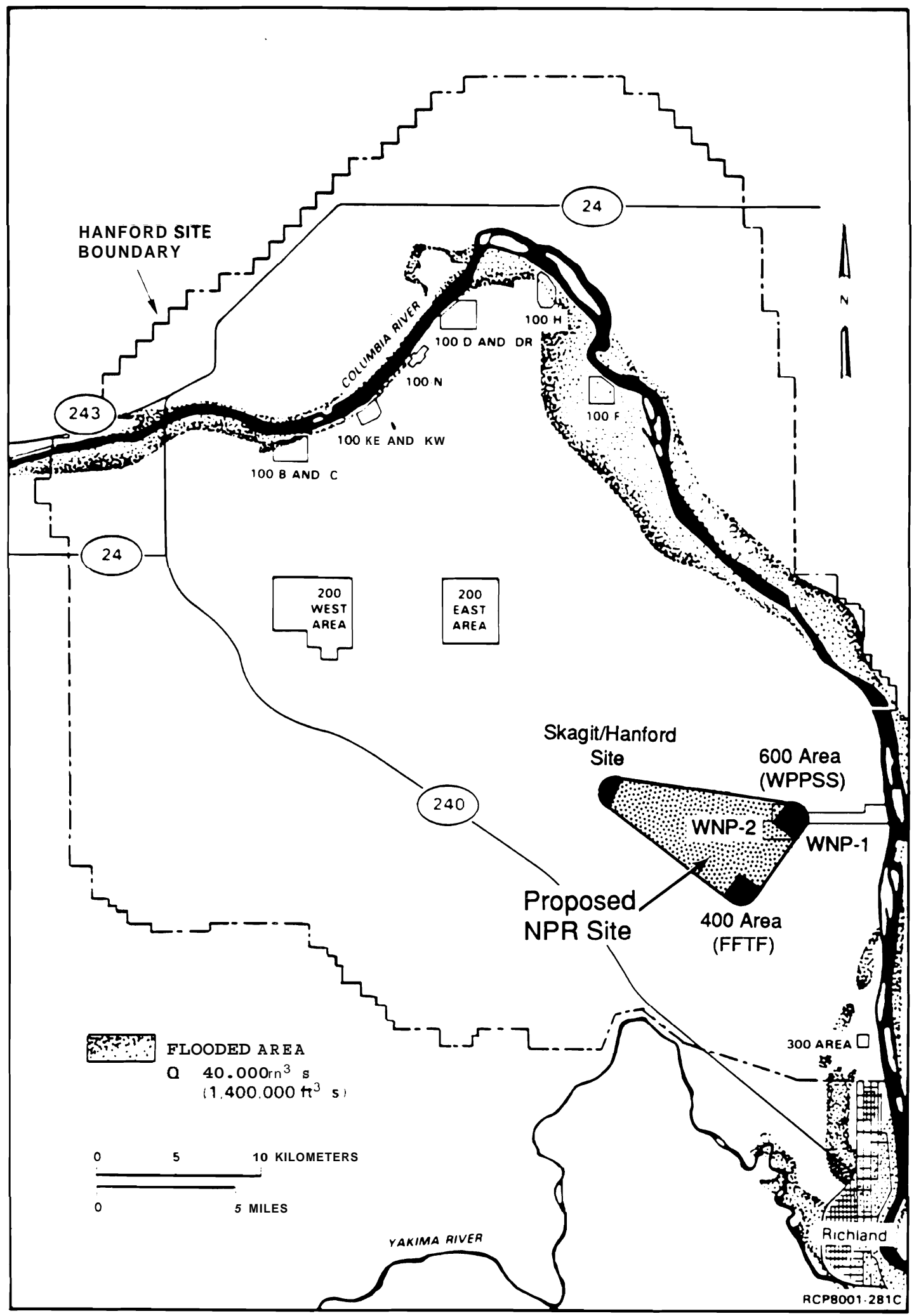

FIGURE 4.4. Flood Area for the Probable Maximum Flood (Cushing 1988) 
extends west of the WNP-2 site, reaches elevations of about $160 \mathrm{~m}$ above MSL, and thus should not be affected by the postulated flood levels.

4.1.1.1.2 Water Quality. Washington State Department of Ecology classifies the Columbia River as Class A (excellent) between Grand Coulee Dam and the mouth of the river near Astoria, Oregon (DOE 1986). The Class A designation requires that industrial uses of this water be compatible with other uses, including drinking water, wildlife, and recreation (PNL 1989a). The Hanford Reach of the Columbia River is the last free-flowing portion of the river in the United States.

Pacific Northwest Laboratory conducts routine monitoring of the Columbia River for measurement of both radiological and nonradiological water-quality parameters. A yearly summary of results, sampling locations, and schedules has been published since 1973 (PNL 1989b). Numerous other water-qua1ity studies have been conducted on the Columbia River relative to the impact of the Hanford Site over the past 37 years. The DOE currently holds a National Pollutant Discharge Elimination System (NPDES) permit for eight effluent. discharges into the Columbia River.

Radiological monitoring shows low levels of radionuclides in samples of Columbia River water. Hydrogen-3 (tritium), iodine-129, and uranium are found in slightly higher concentrations downstream of the Hanford Site than upstream (PNL 1989a), but were far below concentration guidelines established by the DOE and the EPA drinking water standards. Cobalt-60 and iodine were not consistently found in measurable quantities during 1988 in samples of Columbia River water from Priest Rapids Dam, the 300-Area water intake, or' the Richland city pumphouse (PNL 1989a). The average annual strontium concentrations were essentially the same at Priest Rapids Dam and the Richland pumphouse for 1988 (PNL 1989a).

Nonradiological water quality parameters measured during 1988 were similar to those reported in previous years and were within Washington State Water Quality Standards. A tabular summary of Columbia River nonradiological water quality data for 1988 is given in Table 4.1. These data were taken from PNL (1989a). 
TABLE 4.1. Columbia River Water Quality Data for 1988 (PNL 1989a)

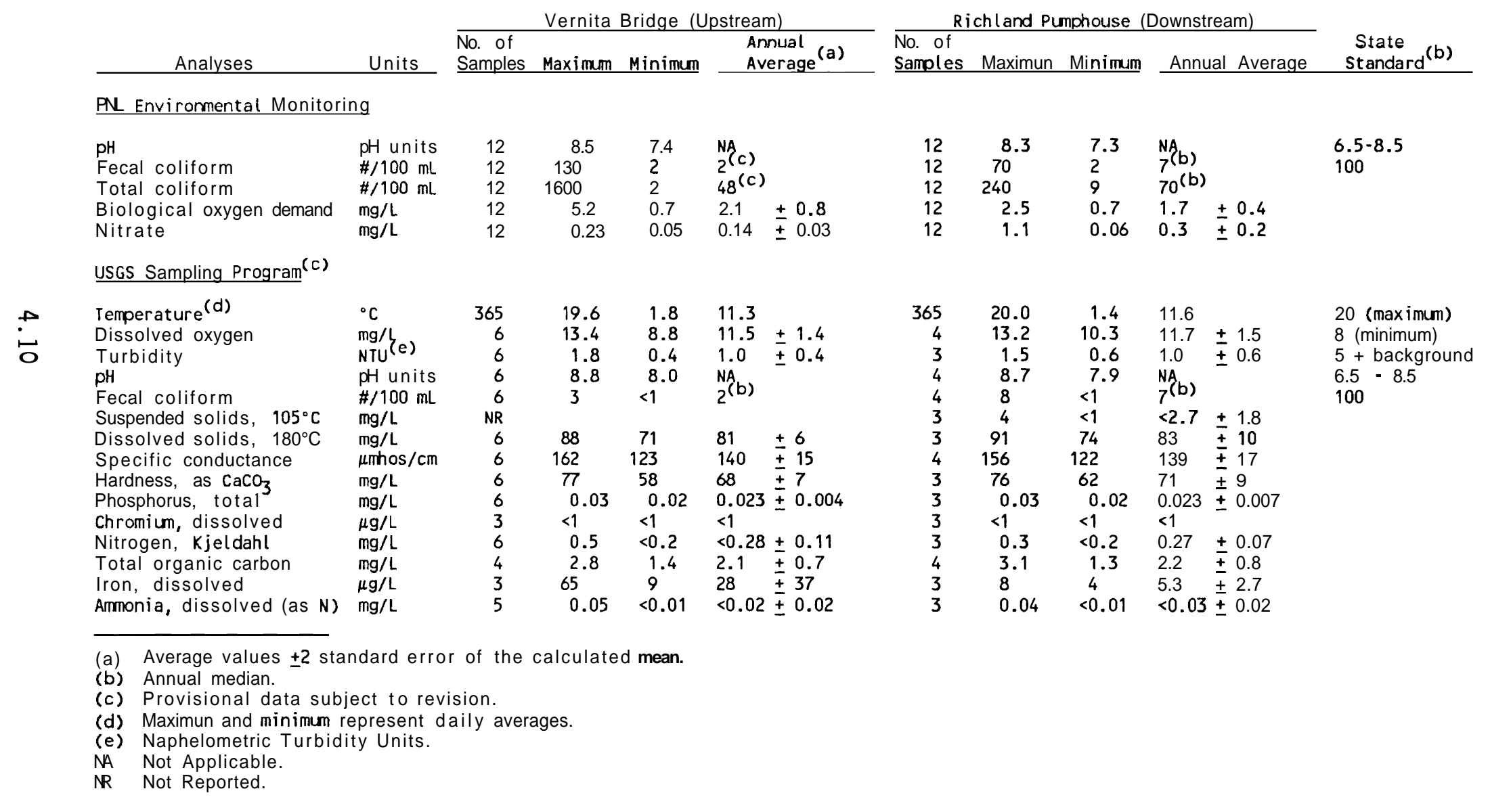


Discharge of nonradioactive water is made to the Columbia River from eight outfalls under an EPA permit issued to DOE Richland Operations Office and regulated by the Hanford NPDES permit. Five of the outfalls are located at 100-N Area, two at 100-K Area, and one at the 300 Area. A summary of these discharges are given for calendar year 1988 in Table 4.2 (WHC 1989). Table 4.3 lists the radioactive releases to the environment from the 100 Areas for 1988 (MHC 1989).

4.1.1.1.3 Water Use. Water use in the Pasco Basin is primarily from surface diversion with groundwater diversions accounting for less than $10 \%$ of the use. Figure 4.5 and Table 4.4 provide the locations of surface water diversions and intakes from the Columbia River and a listing of surface water diversions, vol umes, types of usage, and populations served (DOE 1988). Industrial and agricultural usage represent about 32\% and 58\% respectively, and municipal use about 9\%. Most of the water used by the Hanford Site is withdrawn from the Columbia River. The Hanford Site uses about $81 \%$ of the water withdrawn for industrial purposes. However, with the $\mathrm{N}$ reactor shutdown, and based on data in DOE (1988), these percentages are now closer to $13 \%$ industrial, $75 \%$ agricultural, and 12\% municipal, with the Hanford Site accounting for about $41 \%$ of the water withdrawn for industrial use.

\subsubsection{Lakes, Ponds, Marshes, Wetlands, and Estuaries}

There are no marshes, estuaries, or designated wetlands at the Hanford Site. There are three onsite surface water bodies located near the operating areas. These were sampled periodically during 1988, and the results of analyses for various radionucl ides for 1988 are given in Table 4.5.

B Pond is located near the 200-East Area and was excavated in the mid1950s for disposal of process cooling water and other liquid wastes occasionally containing low levels of radionuclides (PNL 1989a). The second water body (West Lake), also located near the 200-East Area, is naturally occurring, recharged from groundwater, and has not received planned directeffluent discharges from site facilities. The third water body (FFTF Pond), located near the 400 Area was excavated in 1978 for the disposal of cool ing water from the 400 Area facilities. 
TABLE 4.2. Summary of NPDES Data for 1988 (WHC 1989)

NPDES Discharge Points

\begin{tabular}{ll} 
Designation & \multicolumn{1}{c}{ Description } \\
\cline { 2 - 2 } 003 & 181-KE Inlet Screen Backwash \\
004 & $1908-\mathrm{K}$ Out fall \\
005 & $182-\mathrm{N}$ Tank Farm Overflow [36 in. raw water return] \\
006 & $182-\mathrm{N}$ Drain System (42 in. raw water return) \\
007 & $181-\mathrm{N}$ Inlet Screen Backwash \\
009 & 102 in. Outfall (raw water return) \\
N Spring & $100-\mathrm{N}$ Riverbank Springs
\end{tabular}

\begin{tabular}{|c|c|c|c|c|c|c|c|c|c|c|}
\hline $\begin{array}{c}\text { Sample } \\
\text { Parameter } \\
\end{array}$ & & 003 & $\underline{004}$ & $005^{(a)}$ & $005^{(b)}$ & $006^{(c)}$ & $006^{(d)}$ & $\underline{007}$ & 009 & N Springs \\
\hline $\begin{array}{l}\text { Flow } \\
\text { (Mgal/d) }\end{array}$ & $\begin{array}{l}\text { Max. } \\
\text { Avg. }\end{array}$ & $\begin{array}{l}0.02 \\
0.01\end{array}$ & $\begin{array}{l}3.5 \\
2.5\end{array}$ & $\begin{array}{l}5.8 \\
2.4\end{array}$ & 15 (E) & $\begin{array}{l}6.2 \\
1.0\end{array}$ & $\begin{array}{l}7.0 \\
-\end{array}$ & $\begin{array}{l}1.12 \\
0.44\end{array}$ & $\begin{array}{l}302 \\
197\end{array}$ & 1.4 \\
\hline $\begin{array}{l}\text { Temp. } \\
\left({ }^{\circ} \mathrm{F}\right)\end{array}$ & $\begin{array}{l}\text { Max. } \\
\text { Avg. }\end{array}$ & - & $\begin{array}{l}71 \\
57\end{array}$ & $\begin{array}{l}88 \\
58\end{array}$ & - & $\begin{array}{l}69 \\
59\end{array}$ & & & $\begin{array}{l}72 \\
55\end{array}$ & $\begin{array}{l}72 \\
70\end{array}$ \\
\hline $\mathrm{pH}$ & $\begin{array}{l}\text { Max. } \\
\text { Min. } \\
\text { Avg. }\end{array}$ & $\begin{array}{l}- \\
-\end{array}$ & $\begin{array}{l}7.7 \\
6.9 \\
7.3\end{array}$ & $\begin{array}{l}8.5 \\
6.6 \\
7.5\end{array}$ & $\begin{array}{l}- \\
-\end{array}$ & $\begin{array}{l}8.0 \\
7.0 \\
7.7\end{array}$ & $\begin{array}{l}- \\
-\end{array}$ & - & $\begin{array}{l}8.0 \\
6.9 \\
7.7\end{array}$ & $\begin{array}{l}7.6 \\
7.4 \\
7.5\end{array}$ \\
\hline $\begin{array}{l}\mathrm{TSS}(\mathrm{f}) \\
(\mathrm{mg} / \mathrm{L})\end{array}$ & $\begin{array}{l}\text { Max. } \\
\text { Avg. }\end{array}$ & $\begin{array}{r}11.7 \\
4.8\end{array}$ & $\begin{array}{r}14.0 \\
2.5\end{array}$ & $\begin{array}{l}8.9 \\
3.7\end{array}$ & - & $\begin{array}{l}4.4 \\
1.3\end{array}$ & - & $\begin{array}{l}8.8 \\
3.7\end{array}$ & & \\
\hline $\begin{array}{l}\text { Oil and } \\
\text { Grease } \\
(\mathrm{mg} / \mathrm{L})\end{array}$ & $\begin{array}{l}\text { Max. } \\
\text { Avg. }\end{array}$ & - & - & $\begin{array}{r}1.0 \\
<1.0\end{array}$ & - & $\begin{array}{r}1.8 \\
<1.0\end{array}$ & & & & $\begin{array}{l}<1 \\
<1\end{array}$ \\
\hline $\begin{array}{l}\operatorname{Iron} \\
(\mathrm{mg} / \mathrm{l})\end{array}$ & $\begin{array}{l}\text { Max. } \\
\text { Avg. }\end{array}$ & - & - & - & - & - & - & - & - & $\begin{array}{l}<0.080 \\
<0.080\end{array}$ \\
\hline $\begin{array}{l}\text { Amnonia } \\
(\mathrm{mg} / \mathrm{L})\end{array}$ & $\begin{array}{l}\text { Max. } \\
\text { Avg. }\end{array}$ & - & - & - & - & - & - & - & - & $\begin{array}{l}<0.050 \\
<0.050\end{array}$ \\
\hline $\begin{array}{l}\text { Chromium } \\
(\mathrm{mg} / \mathrm{L})\end{array}$ & $\begin{array}{l}\text { Max. } \\
\text { Avg. }\end{array}$ & - & - & - & - & - & - & - & - & $\begin{array}{l}<0.018 \\
<0.010\end{array}$ \\
\hline $\begin{array}{l}\text { Chlorine } \\
(\mathrm{mg} / \mathrm{L})\end{array}$ & $\begin{array}{l}\text { Max. } \\
\text { Avg. }\end{array}$ & $\begin{array}{l}<0.04 \\
<0.04\end{array}$ & - & $\begin{array}{l}<0.04 \\
<0.04\end{array}$ & - & - & - & - & $\begin{array}{l}<0.04 \\
<0.04\end{array}$ & \\
\hline
\end{tabular}

(a) Without low-lift pumps

(b) With low-Lift pumps.

(c) Without fog sprays.

(d) With fog sprays.

(e) - Measurement not required.

(f) Total Suspended Solids. 
TABLE 4.3. Radioactive Releases to the Environment for the 100 Areas for 1988 (MHC 1989)

\begin{tabular}{|c|c|c|c|c|c|c|}
\hline \multirow[b]{2}{*}{$\begin{array}{l}\text { Radio- } \\
\text { nuclide }\end{array}$} & \multicolumn{3}{|c|}{ 1325-N LWDF } & \multicolumn{3}{|c|}{ N Springs } \\
\hline & $\begin{array}{l}\text { Release } \\
\text { (Ci) }\end{array}$ & $\begin{array}{l}\text { Avg. } \\
\text { Conc. } \\
(\mathrm{pCi} / \mathrm{L})\end{array}$ & $\begin{array}{c}\text { Peak } \\
\text { Conc. } \\
(\mathrm{pCi} / \mathrm{L})\end{array}$ & $\begin{array}{l}\text { Release } \\
\text { (Ci) }\end{array}$ & $\begin{array}{l}\text { Avg. } \\
\text { Conc. } \\
(\mathrm{pCi} / \mathrm{L})\end{array}$ & $\begin{array}{c}\text { Peak } \\
\text { Conc. } \\
(\mathrm{pCi} / \mathrm{L})\end{array}$ \\
\hline $\mathrm{H}-3$ & $6.4 \mathrm{E} 1$ & $1.1 \mathrm{E5}$ & $7.9 \mathrm{E} 5$ & $6.4 \mathrm{El}(\mathrm{a})$ & $8.4 E 4$ & $1.0 \mathrm{E5}$ \\
\hline $\mathrm{Mn}-54$ & $5.9 \mathrm{EO}$ & $9.8 \mathrm{E} 3$ & $1.3 \mathrm{E} 5$ & ${ }^{*}(\mathrm{~b})$ & -- & -- \\
\hline Co -60 & $1.1 \mathrm{EI}$ & $1.8 \mathrm{E} 4$ & $4.9 E 5$ & $2.8 \mathrm{E}-2$ & $9.1 \mathrm{El}$ & $4.8 \mathrm{E} 2$ \\
\hline Sr-90 & $1.5 \mathrm{E} 1$ & $2.5 E 4$ & $1.5 E 5$ & 2. $\mathrm{CEO}$ & $6.5 \mathrm{E} 3$ & $8.0 E 3$ \\
\hline Ru-106 & $2.8 \mathrm{EO}$ & $4.6 \mathrm{E} 3$ & $1.7 \mathrm{E} 3$ & $1.5 \mathrm{E}-2$ & $4.8 \mathrm{El}$ & $8.4 \mathrm{El}$ \\
\hline $\mathrm{Sb}-125$ & $8.3 \mathrm{E}-1$ & $1.4 \mathrm{E} 3$ & $2.0 \mathrm{E} 3$ & $1.4 \mathrm{E}-2$ & 4.4E1 & $6.0 \mathrm{E} 1$ \\
\hline Cs -134 & $3.2 \mathrm{E}-1$ & $5.3 \mathrm{E2}$ & $1.3 \mathrm{E} 3$ & $*(b)$ & - - & - - \\
\hline Cs -137 & 8.0EO & $1.3 \mathrm{E} 4$ & $6.5 \mathrm{E} 4$ & $1.7 E-3$ & $5.3 \mathrm{EO}$ & 6.0EO \\
\hline Ce-Pr-144 & $2.1 \mathrm{EO}$ & $3.4 \mathrm{E} 3$ & $8.8 \mathrm{E} 3$ & $*(b)$ & -- & -- \\
\hline Pu-238 & $8.1 E-3$ & $1.3 \mathrm{E} 1$ & $1.1 \mathrm{E} 2$ & $7.3 E-7$ & $2.3 E-3$ & $2.5 E-2$ \\
\hline Pu-239,240 & $4.4 E-2$ & $7.3 \mathrm{El}$ & $7.0 E 2$ & $2.0 \mathrm{E}-6$ & $6.5 E-3$ & $1.1 \mathrm{E}-1$ \\
\hline
\end{tabular}

(a) This value is the same as for tritium $(\mathrm{H}-3)$ discharged to $1325-\mathrm{N}$. Because of its high affinity with water, all $\mathrm{H}-3$ discharged to $1325-\mathrm{N}$ is assumed to eventually reach the Columbia River, but not within 1 year from the time of discharge. The average and peak concentrations of $\mathrm{H}-3$ at the N Springs for 1988 were calculated from analyses of samples routinely collected using a continuous composite sampler system located there.

(b) Indicates that the radionuclide, as a particulate or of high ionicexchange potential, is retained sufficiently within the soil column of $1325-\mathrm{N}$ to be undetectable at the $\mathrm{N}$ Springs.

During 1987, decommissioning activities on Gable Pond (north of 200-East Area) were completed, eliminating this pond and subsequently increasing the volume of $B$ Pond. Monitoring of the former Gable Pond area will continue because the effect of the groundwater mound below the former pond will take a number of years to dissipate. The ponds are inaccessible to the public and did not constitute a direct offsite environmental impact during 1988 (PNL 1989a). 


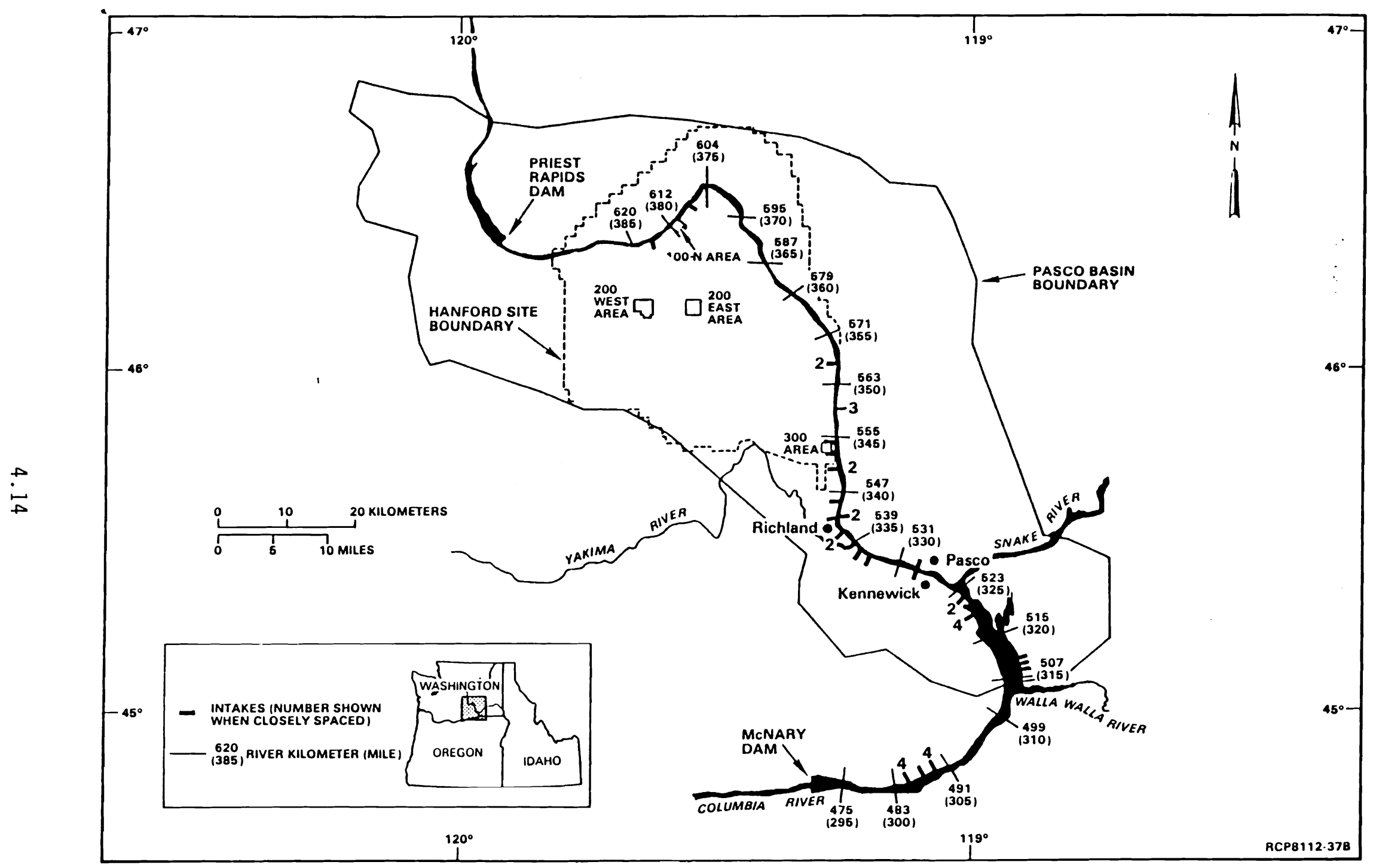

FIGURE 4.5. Surface Water Intakes in the Pasco Basin and Vicinity (DOE 1988) 
TABLE 4.4. Summary of Downstream Surface-Water Uses for Columbia River Water (DOE 1988)

\begin{tabular}{|c|c|c|c|c|c|c|}
\hline \multirow[b]{2}{*}{ User } & \multicolumn{3}{|c|}{ Location of Intake } & \multicolumn{2}{|c|}{$\begin{array}{l}\text { Annual Quantity } \\
\text { Withdrawn }\end{array}$} & \multirow{2}{*}{$\begin{array}{l}\text { Type } \\
\text { of } \\
\text { use (a) }\end{array}$} \\
\hline & $\begin{array}{l}\text { River } \\
m-m\end{array}$ & $\begin{array}{l}\text { River } \\
\text { mi }\end{array}$ & Bank & $\underline{10^{6} \mathrm{~m}^{3}}$ & acre- $f t$ & \\
\hline Hanford Site (200 Areas) & 620 & 385 & Right & (b) & (b) & I \\
\hline Hanford Site (100 K Area) & 615 & 382 & Right & 2.54 & 2,056 & I \\
\hline Hanford Site (100 N Area) & 610 & 379 & Right & 568 & 460,405 & I \\
\hline Hanford Site (200 Areas) & 607 & 377 & Right & (b) & (b) & I \\
\hline $\begin{array}{l}\text { Washington Public Power } \\
\text { Supply System }\end{array}$ & 565 & 351 & Right & 80.4 & 65,160 & I \\
\hline Peter Kiewit Sons Co. & 565 & 351 & Right & 0.89 & 724 & I \\
\hline L. L. Bailey & 558 & 347 & Left & 1.84 & 1,448 & $A$ \\
\hline H. D. Loyd & 558 & 347 & Left & 0.88 & 717 & A \\
\hline Central Premix Cement & 558 & 347 & Left & 1.79 & 1,448 & I \\
\hline Hanford Site (300 Area) & 554 & 344 & Right & 2.33 & 1,888 & I \\
\hline Batte1le Memorial Institute & 552 & 343 & Right & 3.93 & 3,186 & A \\
\hline University of Washington & 550 & 342 & Right & 1.56 & 1,267 & A \\
\hline City of Richland (c) & 550 & 342 & Right & 0.60 & 485 & M \\
\hline City of Richland (c) & 546 & 339 & Right & 27.7 & 22,444 & M \\
\hline City of Richland (c) & 546 & 339 & Right & 20.8 & 16,833 & M \\
\hline City of Richland(c) & 546 & 339 & Right & 27.7 & 22,444 & M \\
\hline City of Richland (c) & 546 & 339 & Right & 83.1 & 67,332 & M \\
\hline E. C. Watts & 544 & 338 & Right & 0.28 & 224 & A \\
\hline H. S. Petty & 544 & 338 & Right & 0.43 & 348 & A \\
\hline N. H. \& M. E. Ketchersid & 544 & $388(d)$ & Left & 1.48 & 1,202 & A \\
\hline G. C. Walkley & 544 & $388(d)$ & Left & 2.07 & 1,680 & $A$ \\
\hline R. T. Justesen & 541 & 336 & Right & 2.27 & 1,839 & A \\
\hline Central Premix Concrete & 541 & 336 & Right & 0.98 & 796 & I \\
\hline Benton County & 534 & 332 & Right & 0.89 & 724 & A \\
\hline City of Richland (c) & 538 & 334 & Right & 1.79 & 1,448 & $A$ \\
\hline City of Kennewick(c) & 528 & 328 & Right & 49.7 & 40,327 & M \\
\hline City of Pasco(c) & 528 & 328 & Left & 31.3 & 25,340 & M \\
\hline F. J. Henokel & 521 & 324 & Right & 0.001 & 11 & A \\
\hline Allied Chemical & 521 & 324 & Right & 3.17 & 2,570 & I \\
\hline
\end{tabular}


TABLE 4.4. (contd)

\begin{tabular}{|c|c|c|c|c|c|c|}
\hline \multirow[b]{2}{*}{ User } & \multicolumn{3}{|c|}{ Location of Intake } & \multicolumn{2}{|c|}{$\begin{array}{c}\text { Annual Quantity } \\
\text { Withdrawn }\end{array}$} & \multirow{2}{*}{$\begin{array}{l}\text { Type } \\
\text { of } \\
\text { use (a) }\end{array}$} \\
\hline & $\begin{array}{l}\text { River } \\
\mathrm{km}\end{array}$ & $\begin{array}{l}\text { River } \\
\text { mi }\end{array}$ & Bank & $10^{6} \mathrm{~m}^{3}$ & acre-ft & \\
\hline Chevron Chemical & 520 & 323 & Right & 3.37 & 2,729 & 】 \\
\hline Chevron Chemical & 520 & 323 & Right & 35.7 & 28,960 & I \\
\hline Philips Pacific Chemical & 520 & 323 & Right & 73.2 & 59,368 & $\mathbf{I}$ \\
\hline Philips Pacific Chemical & 520 & 323 & Right & 17.9 & 14,480 & I \\
\hline Boise Cascade Corp. & 512 & 318 & Left & 21.9 & 17,738 & $\mathbf{I}$ \\
\hline L. D. Hoyte & 510 & 317 & Left & 161 & 130,175 & $A$ \\
\hline D. Howe & 509 & 316 & Left & 5.72 & 4,634 & $A$ \\
\hline Crawford \& Sons & 489 & 304 & Right & 29.3 & 23,747 & $A$ \\
\hline Barborosa Farms & 489 & 304 & Right & 17.9 & 14,480 & $A$ \\
\hline Crawford \& Sons & 489 & 304 & Right & 6.79 & 5,502 & $A$ \\
\hline Rainier National Bank & 489 & 304 & Right & 8.40 & 6,806 & $A$ \\
\hline Anderson \& Coffin & 486 & 302 & Right & 216 & 175,208 & $A$ \\
\hline Horse Heaven Farms & 484 & 301 & Right & 73.2 & 59,368 & $A$ \\
\hline Horse Heaven Farms & 484 & 301 & Right & 491 & 398,200 & $A$ \\
\hline Horse Heaven Farms & 484 & 301 & Right & 259 & 209,960 & A \\
\hline Anderson \& Coffin & 484 & 301 & Right & 215 & 175,208 & $A$ \\
\hline Total & & & & $2,554.8$ & & \\
\hline
\end{tabular}

(a) $\mathrm{A}$ = agricultural, $\mathrm{M}=$ municipal use, $\mathbf{I}$ = industrial use.

(b) Annual water use for the Hanford Site 200 Areas operations withdrawn at river kilometers 620 and 607 (river miles 385 and 377 ) reported as a total figure of $22.4 \times 10^{6} \mathrm{~m}^{3}$.

(c) Municipal populations served by Richland, Kennewick, and Pasco watersupply systems are approximately 34,250, 33,200, and 17,300 people, respectively.

(d) Values shown believed to be typographical error. Correct value believed to be 338 . 
TABLE 4.5. Radionuclide Concentrations in Onsite Ponds in 1988 (PNL 1989a)

\begin{tabular}{|c|c|c|c|c|c|c|c|c|}
\hline \multirow{3}{*}{$\frac{\text { Location }}{\text { West Lake }}$} & \multirow{3}{*}{$\frac{\text { Radionuclide }}{\text { Gross Alpha }}$} & \multirow{3}{*}{$\begin{array}{l}\text { No. of } \\
\text { Samples } \\
3\end{array}$} & \multicolumn{6}{|c|}{ Concentration. $\mathrm{pCi} / \mathrm{L}^{(\mathrm{a})}$} \\
\hline & & & \multicolumn{2}{|c|}{ Maximum } & \multicolumn{2}{|c|}{ Minimum } & \multicolumn{2}{|c|}{ Average } \\
\hline & & & 259 & \pm 15 & 182 & \pm 13 & 226 & \pm 46 \\
\hline & Gross Alpha & 3 & 295 & \pm 47 & 234 & \pm 42 & 267 & \pm 36 \\
\hline & $\mathrm{H}-3$ & 3 & 650 & \pm 150 & 370 & \pm 170 & 480 & \pm 170 \\
\hline & Sr-90 & 3 & 2.6 & $\pm \quad 0.2$ & 2.1 & $\pm \quad 0.1$ & 2.4 & \pm 0.3 \\
\hline & Cs-137 & 3 & 2.3 & \pm 2.1 & -0.2 & \pm 2.4 & 0.8 & $\pm \quad 1.5$ \\
\hline & U-234 & 3 & 175 & $\pm \quad 4$ & 106 & \pm 3 & 145 & \pm 41 \\
\hline & U-235 & 3 & 6.3 & $\pm \quad 0.8$ & 4.0 & \pm 0.6 & 5.3 & $\pm \quad 1.3$ \\
\hline & U- 238 & 3 & 165 & \pm 4 & 100 & \pm & 137 & \pm 39 \\
\hline & U-Total & 3 & 346 & \pm 6 & 210 & \pm & 287 & \pm 81 \\
\hline \multirow[t]{5}{*}{ B Pond } & Gross Alpha & 4 & 0.7 & 0.4 & 0.1 & 0.3 & 0.4 & $\pm \quad 0.2$ \\
\hline & Gross Beta & 4 & 32 & $\pm \quad 4$ & 0.9 & 1.1 & 9.5 & \pm 14.9 \\
\hline & $\mathrm{H}-3$ & 4 & 169 & \pm 162 & -65 & \pm 162 & 78 & \pm 102 \\
\hline & $\mathrm{Sr}-90$ & 4 & 1.6 & 0.1 & 0.4 & 0.08 & 1.1 & \pm 0.6 \\
\hline & Cs-137 & 4 & 1.4 & \pm 1.8 & -0.3 & 2.1 & 0.7 & \pm 0.8 \\
\hline \multirow[t]{5}{*}{ FFTF Pond } & Gross Alpha & 2 & 0.07 & 0.25 & -0.16 & 0.15 & -0.04 & 0.23 \\
\hline & Gross Beta & 2 & 21 & $\pm \quad 4$ & 16 & \pm 3 & 19 & \pm 5 \\
\hline & $\mathrm{H}-3$ & 2 & 5,550 & \pm 280 & 5,200 & \pm 260 & 5,380 & \pm 350 \\
\hline & Cs-137 & 2 & 1.0 & 2.0 & -0.2 & 0.6 & 0.4 & 1.2 \\
\hline & $\mathrm{Na}-22$ & 2 & 0.2 & 1.7 & -0.2 & 2.0 & 0.01 & \pm 0.34 \\
\hline
\end{tabular}

(a) Maximum and minimum values \pm 2 sigma counting error. Averages \pm 2 standard error of the calculated mean.

\subsubsection{Groundwater}

The regional geohydrologic setting of the Pasco Basin is based on the stratigraphic framework consisting of 1) numerous Miocene tholeiitic flood basalts of the Columbia River Basalt Group; 2) relatively minor amounts of intercalated fluvial and volcanoclastic El lensburg Formation sediments; and 3) fluvial, lacustrine, and glaciofluvial suprabasalt sediments. Lateral groundwater movement is known to occur within a shallow, unconfined aquifer consisting of fluvial and lacustrine sediments lying on top of the basalts, and within deeper confined to semiconfined aquifers consisting of basalt flow tops, flow bottom zones, and sedimentary interbeds (D0E 1988). These deeper aquifers are intercalated with aquitards consisting of basalt flow interiors. Vertical flow and leakage between geohydrologic units is inferred and estimated from water level or potentiometric surface data, but is not quantified and direct measurements are not available (DOE 1988). 
The multiaquifer system within the Pasco Basin has been conceptualized as consisting of four geohydrologic units: 1) Grande Ronde Basalt, 2) Wanapum Basalt, 3) Saddle Mountain Basalt, and 4) suprabasalt Hanford and Ringold Formation sediments. Geohydrologic units older than the Grande Ronde Basalt are probably of minor importance to the regional hydrologic dynamics and system.

The Grande Ronde Basalt is the most voluminous and widely spread formation within the Columbia River Basalt Group and has a thickness of at least 2,700 m. The Grande Ronde Basalt geohydrologic unit is composed of the Grande Ronde Basalt and minor intercalated sediments equivalent to or part of the Ellensburg Formation (DOE 1988). Over 50 flows of Grand Ronde Basalt underlie the Pasco Basin, but little is known of the lower 80 to $90 \%$ of this geohyrologic unit. This unit is a confined to semiconfined flow system and is recharged along the margins of the Columbia Plateau where the unit is at or close to the land surface, and by surface and groundwater inflow from lands adjoining the plateau. Vertical movement into and out of the unit is known to occur. Groundwater within the unit in the eastern Pasco Basin is believed to be derived from groundwater inflow from the east and northeast.

The Wanapum Basalt geohydrologic unit consists of basalt flows of the Wanapum Basalt intercalated with minor and discontinuous sedimentary interbeds of the Ellensburg Formation or equivalent sediments. In the Pasco Basin the Wanapum Basalt consists of three members, each consisting of multiple flows. The geohydrologic unit underlies the entire Pasco Basin and has a maximum thickness of $370 \mathrm{~m}$. Groundwater within the Wanapum Basalt geohydrologic unit is confined to semiconfined. Recharge is believed to occur from precipitation where the Wanapum Basalt is not overlain by great thicknesses of younger basalt, leakage from adjoining formations, and surface and groundwater inflow from lands adjoining the plateau. Local recharge is derived from irrigation. Within the Pasco Basin recharge occurs along the anticlinal ridges to the north and west, with recharge in the eastern basin being from groundwater inflow from the east and northeast (DOE 1988). Interbasin transfer and vertical leakage are also believed to contribute to the recharge. 
The Saddle Mountains Basalt geohydrologic unit is composed of the youngest formation of the Columbia River Basalt Group and several thick sedimentary beds of the Ellensburg Formation or equivalent sediments that make up to $25 \%$ of the unit. Within the Pasco Basin, the Saddle Mountains Basalt contains seven members, each with one or more flows. This geohydrologic unit underlies most of the Pasco Basin, attaining a thickness of about $290 \mathrm{~m}$, but is absent along the northwest part of the basin and along some anticlinal ridges. Groundwater in the Saddle Mountains geohydrologic unit is confined to semiconfined, with recharge and discharge believed to be local (DOE 1988).

The rock materials that overlie the basalts in the structural and topographic basins within the Columbia Plateau generally consist of MiocenePliocene sediments, volcanics, Pleistocene sediments including those from catastrophic flooding, and Holocene sediments consisting mainly of alluvium and eolian deposits. The suprabasalt geohydrologic unit (referred to as the Hanford/Ringold unit) consists principally of the Mocene-Pliocene Ringold Formation stream, lake, and alluvial materials, and the Pleistocene catastrophic flood deposits informally called the Hanford formation. Groundwater within the suprabasalt geohydrologic unit is generally unconfined, with recharge and discharge usually coincident with topographic highs and lows (DOE 1988). The Hanford/Ringold unit is essentially restricted to the Pasco Basin with principal recharge occurring along the periphery of the basin from precipitation and ephemeral streams. Little, if any, natural recharge occurs within the Hanford Site, but artificial recharge occurs from liquid waste disposal activities. Recharge from irrigation occurs east and north of the Columbia River and in the synclinal valleys west of the Hanford Site. Upward leakage from lower aquifers into the unconfined aquifer is believed to occur in the northern and eastern sections of the Hanford Site. Groundwater discharge is primarily to the Columbia River.

Groundwater under the site occurs under unconfined and confined conditions. The unconfined aquifer is contained within the glaciofluvial sands and gravels and within the Ringold Formation. It is dominated by the middle member of the Ringold Formation, consisting of sorted sands and gravels. The bottom of the aquifer is the basalt surface or, in some areas, the clay zones of the lower member of the Ringold Formation. The confined aquifers consist 
of sedimentary interbeds and/or interflow zones that occur between dense basalt flows in the Columbia River Basalt Group. The main waterbearing portions of the interflow zones occur within a network of interconnecting vesicles and fractures of the flow tops or flow bottoms.

Sources of natural recharge to the unconfined aquifer are rainfall and runoff from the higher bordering elevations, water infiltrating from small ephemeral streams, and river water along influent reaches of the Yakima and Columbia Rivers. The movement of precipitation through the unsaturated (vadose) zone has been studied at several locations on the Hanford Site (DOE 1989). Conclusions from these studies are varied depending on the location studied. Some investigators conclude that no downward percolation of precipitation occurs on the 200-Area Plateau where soil texture is varied and is layered with depth, and that all moisture penetrating the soil is removed by evaporation. Others have observed downward water movement below the root zone in tests conducted near the 300 Area, where soils are coarse-textured and precipitation was above normal (DOE 1987).

From the recharge areas to the west, the groundwater flows downgradient to the discharge areas, primarily along the Columbia River. This general west-to-east flow pattern is interrupted locally by the groundwater mounds in the 200 Areas. Figure 4.6 shows the elevations of the water table, or top of the unconfined aquifer for June 1987. From the 200 Areas, there is also a component of groundwater flow to the north, between Gable Mountain and Gable Butte. These flow directions represent present conditions. The aquifer is dynamic and responds to changes in natural and artificial recharge.

Local recharge to the shallow basalts is believed to result from infil- . tration of precipitation and runoff along the margins of the Pasco Basin. Regional recharge of the deep basalts is thought to result from interbasin groundwater movement originating northeast and northwest of the Pasco Basin in areas where the Wanapum and Grande Ronde Basalts crop out extensively (DOE 1986). Groundwater discharge from the shallow basalt is probably to the overlying unconfined aquifer and the Columbia River. The discharge area(s) 


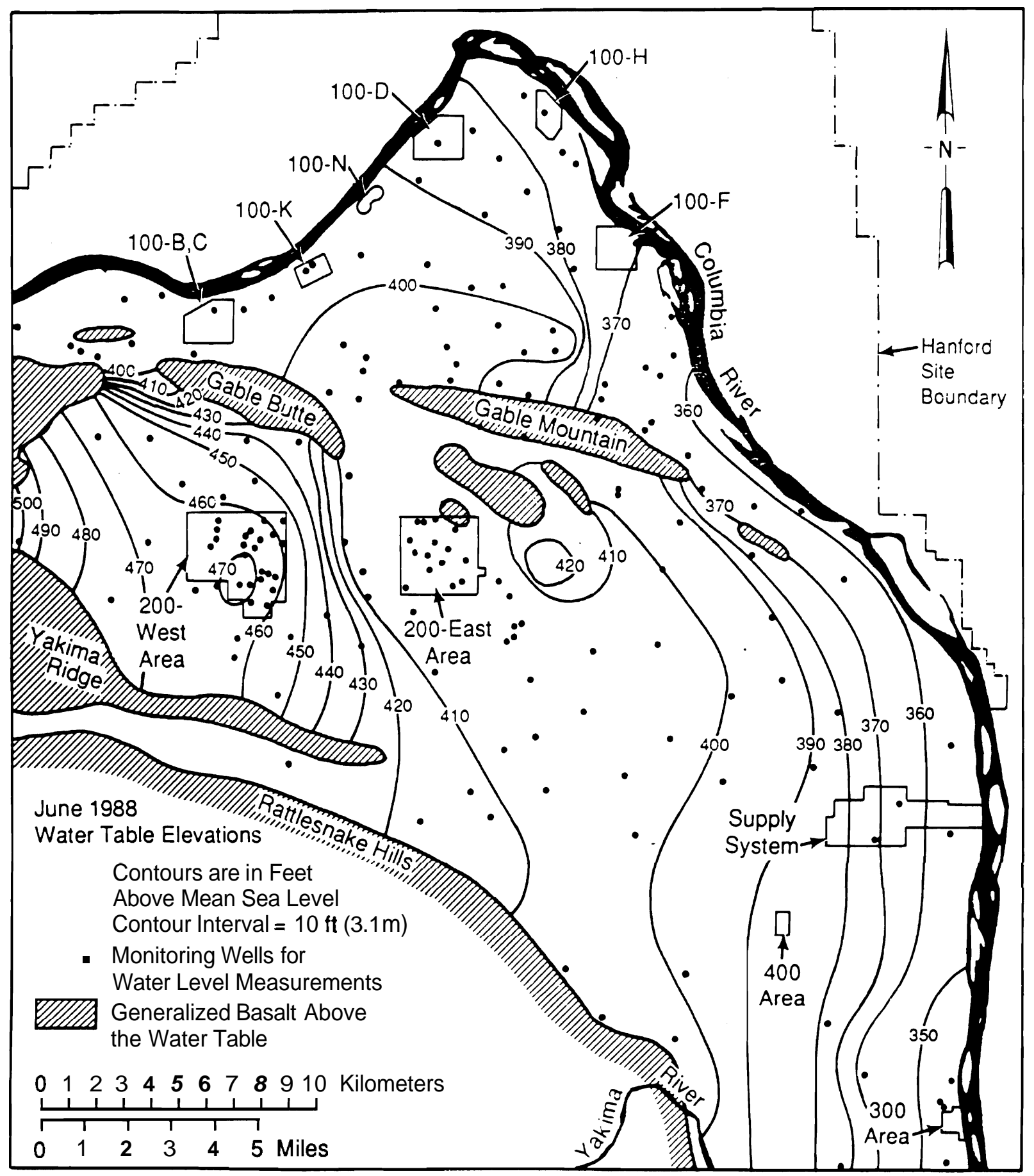

FIGURE 4.6. Water Table Elevations for June 1988 (PNL 1989a) 
for the deep groundwaters is presently uncertain, but flow is believed to be generally southeast with discharge speculated to be south of the Hanford Site (DOE 1986).

Waste-water ponds on the Hanford Site have artificially recharged the unconfined aquifer below the ZOO-East and 200-West areas. The increase in water table elevations was most rapid from 1950 to 1960, and apparently had nearly reached equilibrium between the unconfined aquifer and the recharge during 1970 to 1980 when only small increases in water table elevations occurred. Waste-water discharges from 200-West area were significantly reduced in 1984 (DOE 1988).

A large number of wells within the Hanford Site have supplied information on the geologic and hydrologic setting. Wells that were used to develop the geohydrologic description for the former Skagit/Hanford potential locations are shown in Watson et al. (1984). The potential NPR site area includes two deep wells at the former Skagit/Hanford site, one of which is drilled to a depth of $1,530 \mathrm{~m}$; a number of WPPSS wells that reach the basalt or reached the basalt and drilled into it; and several deep wells at the FFTF site with one to a depth of about $600 \mathrm{~m}$.

Depth to groundwater in the proposed NPR site area varies from about $15 \mathrm{~m}$ at the eastern end, near the WPPPS sites, to approximately $38 \mathrm{~m}$ at the western boundary near the FFIF site and the former Skagit/Hanford site.

\subsubsection{Hvdrologic Properties}

Hydrologic data regarding the unconfined aquifer outside the Hanford Site are based primarily on specific-capacity tests, or tests from which the well discharge is divided by the water-level drawdown in the well. High specific capacities usually reflect high sediment transmissivities.

Table 4.6 summarizes the hydraulic properties of the unconfined aquifer in the Pasco Basin, based on data from Ecology and data from the Hanford Site (DOE 1988).

Recent hydrogeological characterization work in the 200 Areas has supplied hydraulic properties of the unconfined aquifer near the center of the Hanford Site (PNL 1989b). In 200-East Area, the uppermost hydrogeologic unit 
TABLE 4.6. Representative Hydraulic Properties of the Unconfined Aquifer in the Pasco Basin (DOE 1988)

\section{Stratiaraphic interval}

Hanford Formation

Undifferentiated Hanford Formation and middle Ringold unit

Middle Ringold unit

Lower Ringold unit

Reqi on

North of Gable Butte and Gable Mountain

On the flank of Gable Butte and Gable Mountain along paleochannels

Other areas on the Hanford Site

Throughout the suprabasalt aquifer
Hydraulic conductivity $(\mathrm{m} / \mathrm{s})(\mathrm{a})$

$1.7 \times 10^{-3}-7.0 \times 10^{-2}$

$3.5 \times 10^{-4}-2.5 \times 10^{-2}$

$7.0 \times 10^{-5}-2.1 \times 10^{-3}$

$3.8 \times 10^{-7}-3.5 \times 10^{-5}$

Transmis sjvity $\left(\mathrm{m}^{2} / \mathrm{s}\right)(\mathrm{b})$

$4.3 \times 10^{-3}-2.7 \times 10^{-2}$

$4.3 \times 10^{-2}-6.5 \times 10^{-1}$

$2.3 \times 10^{-3}-4.3 \times 10^{-2}$

$\underline{\text { Storase coefficients }}$

$0.01-0.1$

Source: Gephart et al. (1979, p. III-77).

(a) To convert from $\mathrm{m} / \mathrm{s}$ to $\mathrm{ft} / \mathrm{d}$, multiply by $2.9 \times 10^{5}$.

(b) To convert from $\mathrm{m}^{2} / \mathrm{s}$ to $\mathrm{ft}^{2} / \mathrm{s}$, multiply by $9.3 \times 10^{5}$.

within the unconfined aquifer is the Hanford formation, although a few wells encountered Ringold gravels above the Elephant Mountain Member of the Saddle Mountains Basalt, which forms the base of the unconfined aquifer. This portion of the aquifer is generally highly transmissive with values in the range of $1.5 \times 10^{-2} \mathrm{~m}^{2} / \mathrm{s}$ to $1.2 \times 10^{-1} \mathrm{~m}^{2} / \mathrm{s}$, and resultant hydraulic conductivities between $4.9 \times 10^{-3} \mathrm{~m} / \mathrm{s}$ and $2.3 \times 10^{-2} \mathrm{~m} / \mathrm{s}$. Graham et a1. (1981) reported storativity values of 0.002 to 0.07 , with the lower value associated with the Ringold and the upper value with the Hanford formation, and effective porosities between $10 \%$ and $30 \%$, again associated with the Ringold and Hanford formations respectively.

In the 200-West Area, the uppermost part of the unconfined aquifer is within the middle Ringold unit. Transmissivity values varied from a low of 
$1.5 \times 10^{-5} \mathrm{~m}^{2} / \mathrm{s}$ to a maximum of $5.5 \times 10^{-2} \mathrm{~m}^{2} / \mathrm{s}$, with hydraulic conductivities ranging from $2.1 \times 10^{-7} \mathrm{~m} / \mathrm{s}$ to $7.0 \times 10^{-4} \mathrm{~m} / \mathrm{s}$ (PNL 1989b). Transmissivities in the more consolidated sediments at the base of the unconfined aquifer were between $4.5 \times 10^{-4} \mathrm{~m}^{2} / \mathrm{s}$ and $9.7 \times 10^{-4} \mathrm{~m}^{2} / \mathrm{s}$, with hydraulic conductivities from $5.9 \times 10^{-6} \mathrm{~m} / \mathrm{s}$ to $1.4 \times 10^{-5} \mathrm{~m} / \mathrm{s}$. Storativity values for the 200-West Area vary from 0.001 to 0.038 .

For the confined and semiconfined aquifers within the basalt formations, the flow tops and sedimentary interbeds exhibit the highest hydraulic conductivities. Groundwater generally occurs in flow tops and interbeds separated by flow interiors of low hydraulic conductivity. The flow interiors have been found to yield very small quantities of water while the thin flow contact zones yield relatively large quantities. Hydraulic conductivities may be as great as $1.5 \mathrm{~m} / \mathrm{s}$ for horizontally permeable zones, while vertical hydraulic conductivity may be as small as $1.5 \times 10^{-8} \mathrm{~m} / \mathrm{s}$ (DOE 1988).

Transmissivity values calculated from specific capacity data for basalt formations of the Columbia Plateau are given in DOE (1988). Most of the wells outside the Hanford Site draw water from a number of zones within a given formation and the calculated transmissivities probably reflect the zones that are most highly transmissive. Figure 4.7 shows frequency distributions of transmissivity values based on specific capacity data for the Saddle Mountains and Wanapum basalts respectively. Additional information can be found in DOE (1988).

4.1.2.1.1 Water Quality. As part of the continuing environmental monitoring program, groundwater monitoring reports have been issued since 1956 and are now published in the Hanford Site Environmental Report, which is issued by calendar year. The shallow, unconfined aquifer in the Pasco Basin and on the Hanford Site contains waters of a dilute (less than or about $350 \mathrm{mg} /$ L total dissolved solids) calcium bicarbonate type. Other principle constituents include sulfate, silica, magnesium, and nitrate. Variability in chemical composition exists within the unconfined aquifer. In part because of natural variation in the composition of the aquifer material; in part 


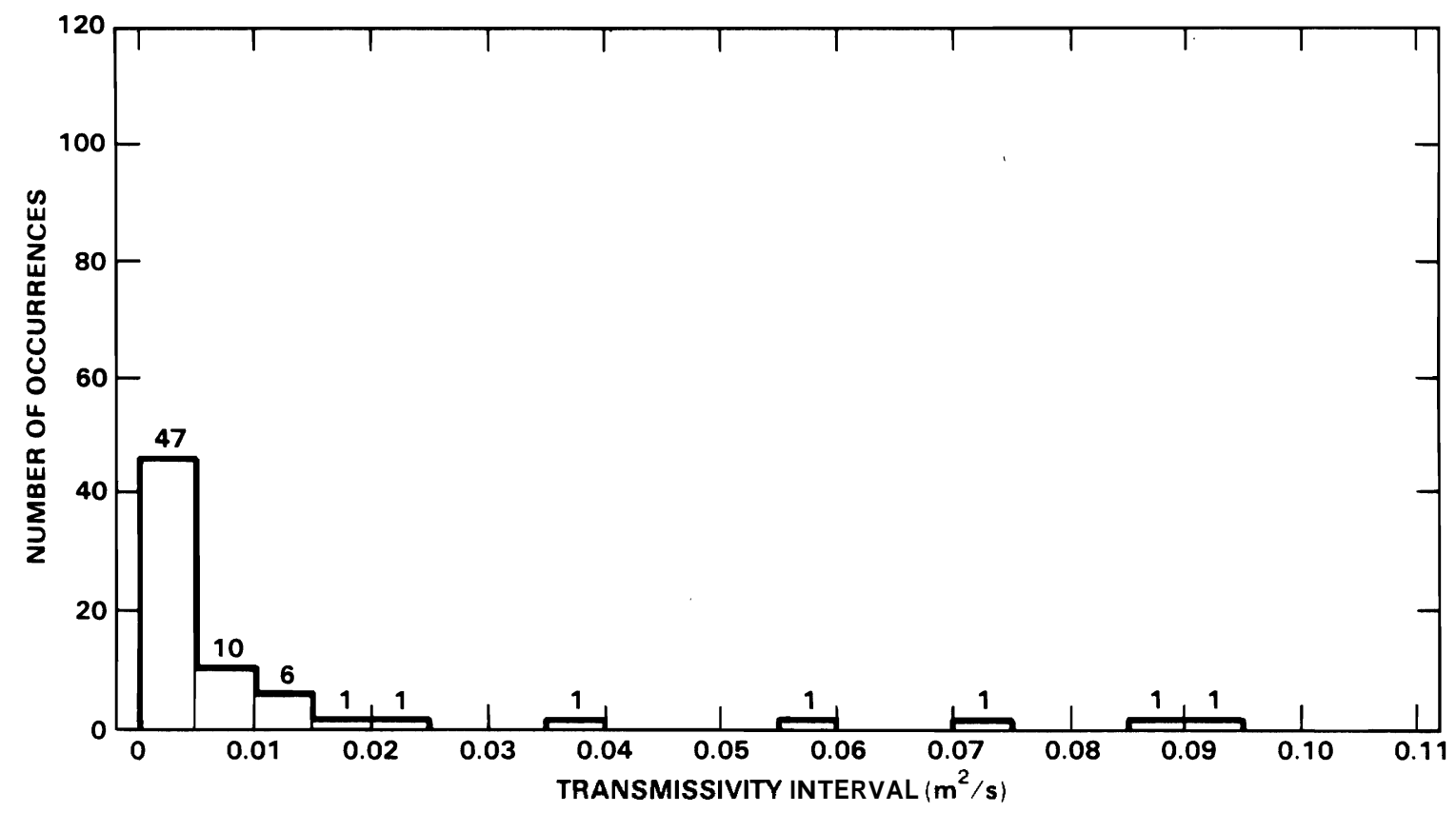

NOTE. TO CONVERT METERS TO FEET. MULTIPLY BY 3.28

Saddle Mountains Basalt

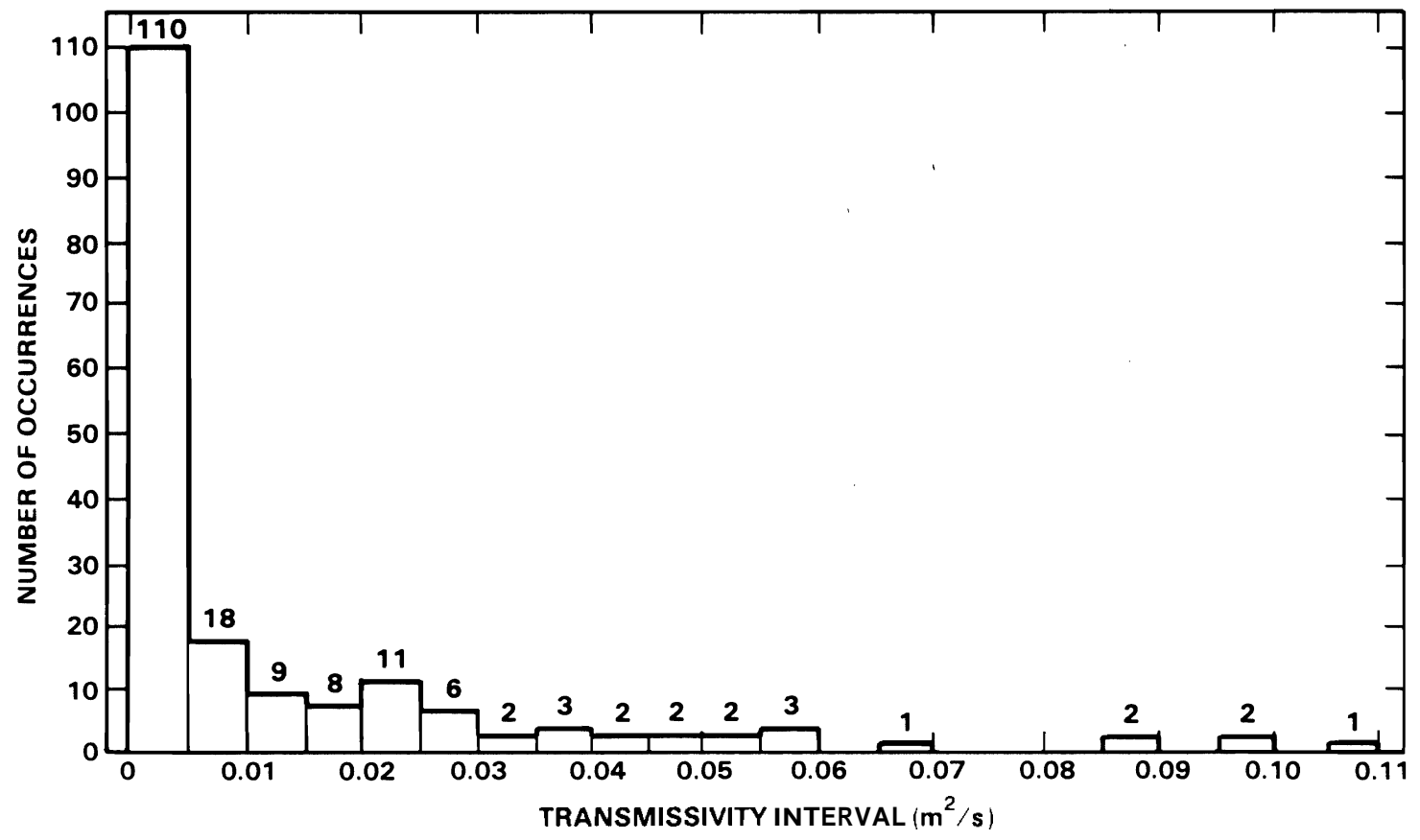

NOTE: TO CONVERT METERS TO FEET. MULTIPLY BY $\mathbf{3 . 2 8}$

Wanapum Basalt

FIGURE 4.7. Histograms Showing the Frequency of Transmissivity Occurrence within the Saddle Mountains Basalt and the Wanapum Basalt, Based on Specific Capacity of Wells (DOE 1988) 
because of agricultural and irrigation practices north, east, and west of the Hanford Site; and, on the Hanford Site, in part because of liquid waste disposal.

Graham et al. (1981) compared analyses of unconfined quifer water samples taken by the U.S. Geological Survey (USGS) in the Pasco Basin but off the Hanford Site with samples taken by PNL and the USGS on the Hanford Site for the years 1974-1979. In general, Hanford Site groundwater analyses showed higher levels of chemical constituents and temperatures than were reflected in the analyses of offsite samples.

Elevated levels of some constituents in the Hanford Site groundwater result from releases from various liquid-waste disposal facilities. Nitrate, tritium, and total beta contamination have migrated away from these sites in a general west-to-east direction. Some longer-lived radionuclides such as strontium-90 and cesium-137 have reached the groundwater, primarily through liquid-waste disposal cribs. Minor quantities of longer-lived radionuclides have reached the water table via a failed.groundwater monitoring we 11 casing; and through reverse well injection, a disposal practice that was discontinued at Hanford in 1947 (Smith 1980). Waste disposal practices and resultant impacts are described in ERDA (1975) and DOE (1987). These practices have in the past led to local contamination of the site and the unconfined aquifer. However, the contamination has not resulted in, and is not expected to result in, any significant radiation exposure to the public (DOE 1987).

Radioactive and nonradioactive effluents are discharged to the environment from operating facilities in the 200 Areas (Coony and Thomas 1989). These effluents, in general, are discharged to the soil column. Cooling water represents by far the largest vol ume of potentially radioactive liquid effluent. Tables 4.7 and 4.8 show the volume of 200 -Area effluents discharged to radioactive disposal facilities for 1987 and the nonradioactive indicators in radioactive effluents in the 200 Area for 1987 respectively. Details can be found in Coony and Thomas (1989). Additional treatment systems for these effluents are being designed and installed pursuant to the schedule set forth in the Hanford Federal Facility Agreement and Consent order, which was jointly issued by the DOE, the EPA, and Ecology in May 1989. 
TABLE 4.7. Volume of Hanford Site 200 Areas Liquid Effluents Discharged to Radioactive Disposal Facilities in 1988 (Coony and Thomas 1989)

\begin{tabular}{|c|c|c|}
\hline Effluent & $\begin{array}{l}\text { Disposal } \\
\text { Facilitv }\end{array}$ & $\begin{array}{l}\text { Volume in } \\
1988(\mathrm{~L})\end{array}$ \\
\hline PUREX Process condensate & 216-A-45 Crib & $4.88 \mathrm{E} 7$ \\
\hline PUREX Ammonia scrubber distillate(a) & & 0 \\
\hline PUREX Coil and steam condensate & $\begin{array}{l}216-A-30 \text { Crib } \\
216-A-37-2 \text { Crib }\end{array}$ & $3.74 \mathrm{E} 8$ \\
\hline PUREX Chemical sewer & 216-B-3 Pond & $1.29 \mathrm{E} 9$ \\
\hline PUREX Cooling water & 216-B-3 Pond & $1.01 E 10$ \\
\hline $\mathrm{UO}_{3}$ Plant process condensate $(\mathrm{b})$ & $\begin{array}{l}216-U-12 \text { Crib } \\
216-U-17 \text { Crib }\end{array}$ & $8.29 \mathrm{E} 5$ \\
\hline $\mathrm{UO}_{3}$ Plant cooling water and steam condensate & 216-U-14 Ditch & 2.73E8 \\
\hline B Plant cooling water & 216-B-3 Pond & $3.32 \mathrm{Eg}$ \\
\hline B Plant steam condensate & 216-B-55 Crib & $2.65 \mathrm{E} 6$ \\
\hline B Plant steam chemical sewer & 216-B-63 Trench & 2.89E8 \\
\hline 244-AR Vault cooling water & 216-B-3 Pond & $6.87 \mathrm{E} 7$ \\
\hline A Tank Farm cooling water & 216-B-3 Pond & $9.66 \mathrm{E} 8$ \\
\hline 242-A Evaporator/Crystallizer cooling water & 216-B-3 Pond & $6.34 \mathrm{Eg}$ \\
\hline 242-A Evaporator/Crystallizer steam condensate & 216-B-3 Pond & $6.55 \mathrm{E} 7$ \\
\hline $\begin{array}{l}\text { 242-A Evaporator/Crystallizer process } \\
\text { condensate }\end{array}$ & 216-A-37-1 Crib & $4.92 E 7$ \\
\hline 242-S Evaporator/Crystallizer steam condensate & 216-U-14 Ditch & $1.39 E 7$ \\
\hline 222-S Laboratory chemical sewer & $216-S-26$ Crib & $1.89 \mathrm{E} 7$ \\
\hline REDOX Chemical sewer & 216-S-10 Ditch & $2.11 \mathrm{E} 8$ \\
\hline Laundry wastewater & 216-W-LWC Crib & $1.40 \mathrm{E} 7$ \\
\hline PFP Wastewater & $216-Z-20$ & $2.29 \mathrm{E} 8$ \\
\hline $\begin{array}{l}\text { Total volume, potentially radioactive } \\
\text { effluents }\end{array}$ & & $2.37 \mathrm{E} 10$ \\
\hline
\end{tabular}

(a) Ammonia scrubber waste was not processed at the PUREX Plant in 1988.

(b) The connection to the 216-U-17 crib was completed on January 31, 1988, and the use of the 216-U-12 crib was discontinued.

PUREX = Plutonium-uranium extraction.

REDOX = Reduction oxidation .

PFP $=$ Plutonium Finishing Plant. 
TABLE 4.8. Nonradioactive Indicators in Radioactive Liquid Effluents in the Hanford 200 Area During 1988 (Coony and Thomas 1989)

Effl uent

PUREX process condensate

PUREX chemical sewer

$\mathrm{UO}_{3}$ Plant process condensate

$B$ Plant chemical sewer

242-A evaporator/crystallizer process condensate

222-S Laboratory chemical sewer

West Area laundry crib

$Z$ Plant wastewater

Total

\begin{tabular}{|c|c|c|c|}
\hline \multicolumn{2}{|c|}{ Nitrate $^{(a)}$} & \multicolumn{2}{|c|}{ TOC } \\
\hline $\begin{array}{l}\text { Annual } \\
\text { average } \\
(\mathrm{mg} / \mathrm{L})\end{array}$ & $\begin{array}{c}\text { Annual } \\
\text { mass } \\
(\mathrm{kg}) \\
\end{array}$ & $\begin{array}{l}\text { Monthly } \\
\text { maximum } \\
\text { (mg/L) }\end{array}$ & $\begin{array}{c}\text { Annual } \\
\text { mass } \\
(\mathrm{kg}) \\
\end{array}$ \\
\hline 69 & 3,400 & 77 & 2,300 \\
\hline 1 & 1,600 & 7 & 4,200 \\
\hline 870 & 690 & (b) & (b) \\
\hline 1 & 360 & 24 & 1,800 \\
\hline 1 & 61 & 30 & 630 \\
\hline 7 & 190 & 4 & 87 \\
\hline (b) & (b) & 28 & 160 \\
\hline 1 & 270 & 6 & 640 \\
\hline$N / A$ & 6,600 & $N / A$ & 9,796 \\
\hline
\end{tabular}

(a) Values for nitrate are reported as $\mathrm{NO}_{3}$.

(b) Analysis is not necessary as determined from expected inventory during operations.

TOC = Total organic carbon .

PUREX = Plutonium-uranium extraction.

$\mathrm{N} / \mathrm{A}=$ Not appl icable.

Therefore, these discharges are discussed to provide historical information only; they are not expected to exist in present form at the time an NPR would be operational.

Springs are common on basalt ridges surrounding the Pasco Basin. Geochemically, spring waters are of a calcium-sodi um-bicarbonate type with low dissolved sol ids (approximately 200 to $400 \mathrm{mg} / \mathrm{L}$; DOE 1986). Compositionally, these waters are similar to shallow local groundwaters (unconfined aquifer and upper Saddle Mountains Basalt). However, they are readily distinguishable from waters of the lower Saddle Mountains (Mabton interbed) and the 
Wanapum and Grande Ronde Basalts, which are of sodium-bicarbonate to sodiumchloride-bicarbonate (or sodium-chloride-sulfate) type. Currently there is no evidence suggesting that these spring waters contain any significant component of deeper groundwater.

Areal and stratigraphic changes in groundwater chemistry characterize basalt groundwaters beneath the Hanford Site (Graham et al. 1981). The stratigraphic position of these changes is believed to delineate flow-system boundaries, and to identify chemical evolution taking place along groundwater flow paths. Some potential mixing of groundwaters has also been located using these data. The rate of mixing is unknown at present.

Overall, waters of the shallow basalts are of a sodium-bicarbonate chemical type; those of the deep basalts are of a sodium-chloride chemical type (DOE 1986). On a location-by-location basis, chemical and isotopic shifts can be pronounced (DOE 1982b). The stratigraphic boundaries separating chemical types vary depending on location. At the no longer considered reference repository location, groundwater composition was found to change systematically as a function of depth (DOE 1986).

lodine-129 and tritium have been detected in confined groundwater zones in the Saddle Mountains Basalt beneath the Hanford Site (DOE 1986). Two areas were found where measured concentrations of iodine-129 were above what is considered to be natural background. These areas are in the vicinity of West Lake and Gable Mountain Pond, and at one borehole located approximately $20 \mathrm{~km}$ to the southeast near the horn of the Yakima River.

\subsubsection{Water Use-}

Approximately $50 \%$ of the wells in the Pasco Basin are for domestic use and are generally shallow (less than $150 \mathrm{~m}$ ). Agricultural wells, used for irrigation and stock supply, make up the second-largest category of well use; about $24 \%$ for the Pasco Basin. Industrial users account for only about $3 \%$ of the wells (DOE 1988).

The principal users of groundwater within the Hanford Site are the FFTF with a 1988 use of $142,000 \mathrm{~m}^{3}$ from two wells in the unconfined aquifer, and PNL with a water supply from a spring on the side of Rattlesnake Mountain. 
Regional effects of water use activities are apparent in some areas where the local water tables or potentiometric levels have declined because of withdrawals from wells. In other areas, water levels in the shallow aquifers have risen because of artificial recharge mechanisms such as excessive application of imported irrigation water or impoundment of streams.

\subsubsection{Monitoring}

Environmental monitoring has been conducted at Hanford for the past 44 years. As part of this continuing program, groundwater samples from 511 monitoring wells were collected for radiological analysis and chemical data gathered on 158 wells during 1988 (PNL 1989a). Figure 4.8 shows the locations of the monitoring wells, both for the unconfined and the confined aquifers.

The radiological constituents to be monitored in the unconfined aquifer at Hanford are based on historical waste management practices. Because tritium is known to be present in the waste streams discharged to the soil column, and because it is the most mobile nuclide at the site, the tritium plume reflects the extent of contamination of the groundwater from over 40 years of Hanford operations. The highest tritium concentrations in the 200-East area and throughout the site are found in wells near cribs that have received effluents from the Plutonium Urani um Extraction (PUREX) Plant (PNL 1989a). The tritium plume is shown for 1988 in Figure 4.9. Separate pulses in the plume are associated with the two episodes of PUREX operations--from 1956 to 1972 and from 1983 to the present.

The tritium plumes in 200-West area, which extend from the Reduction Oxidation (REDOX) Plant, are moving slowly to the east and north from the southern part of 200 West, and to the north and east from the north central part of 200 West.

Nitrate is associated with process condensate liquid wastes and also reflects the extensive use of nitric acid in decontamination and chemical reprocessing operations. Like tritium, nitrate can be used to help define the extent of contamination because it is present in many waste streams and is mobile in groundwater. The distribution of nitrate in the unconfined aquifer is shown for 1988 in Figure 4.10 . 


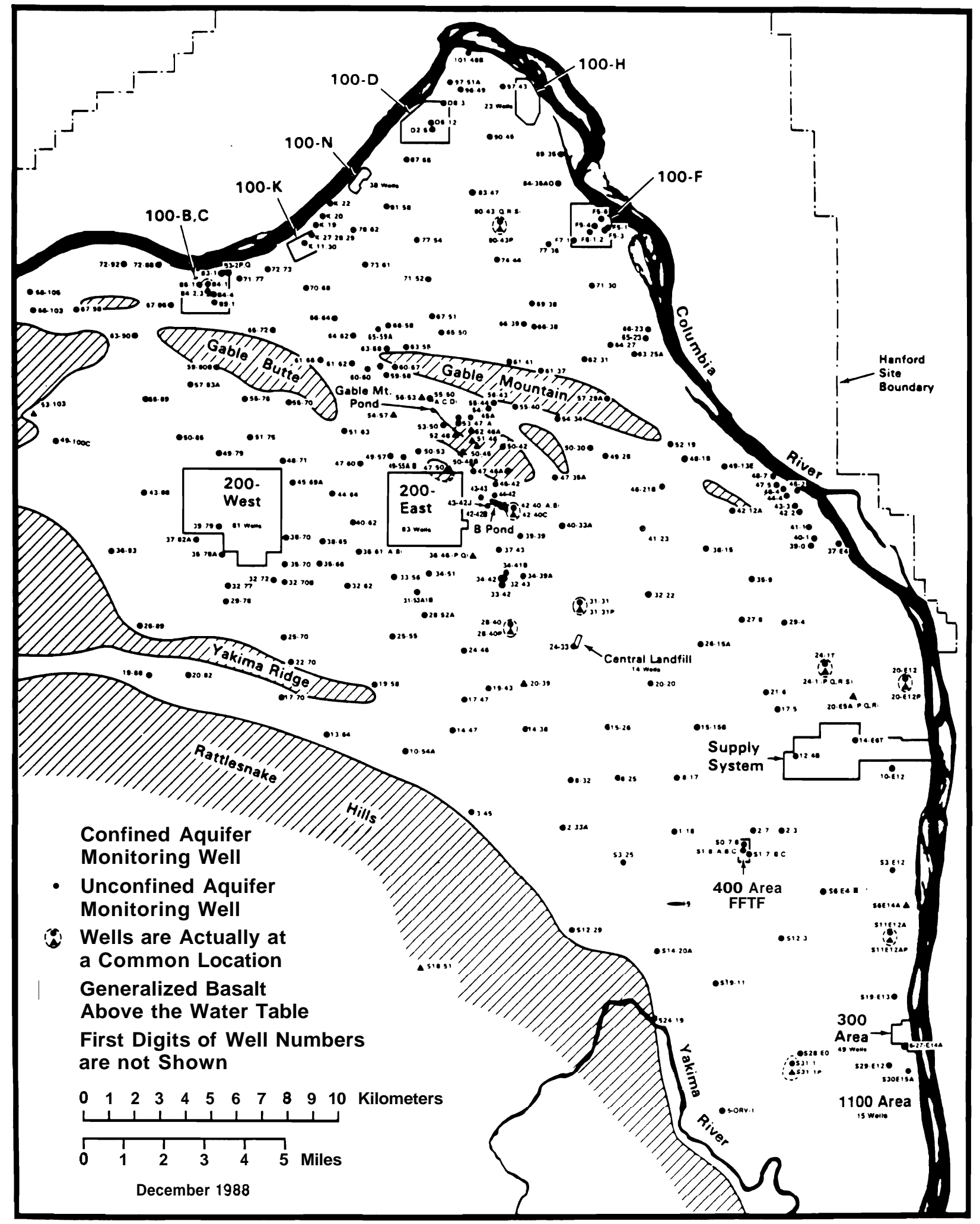

FIGURE 4.8. Hanford Site Monitoring Well Locations (PNL 1989a) 


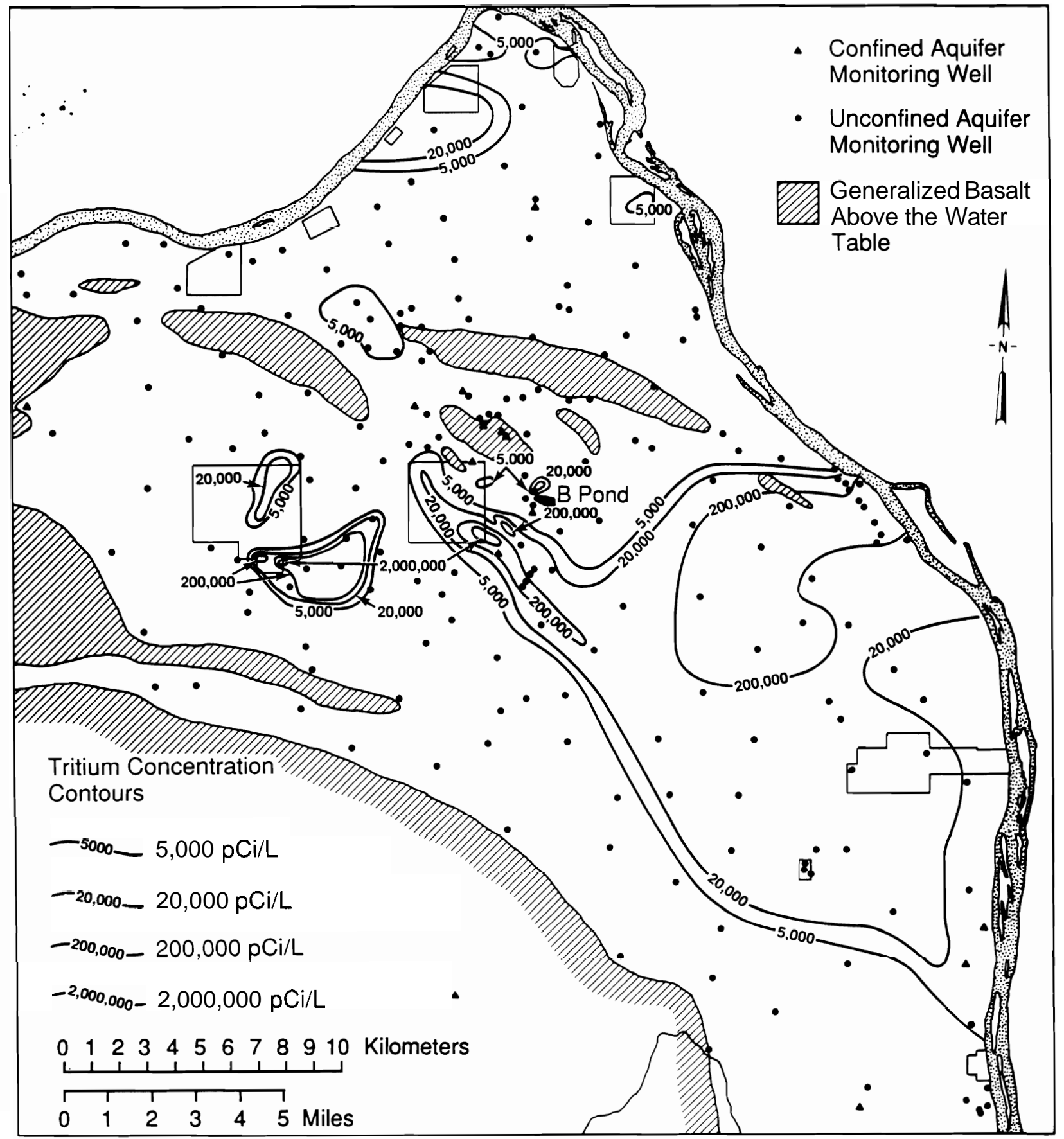

FIGURE 4.9. Tritium Concentration in the Hanford Site Unconfined Aquifer in 1988 (PNL 1989a) 


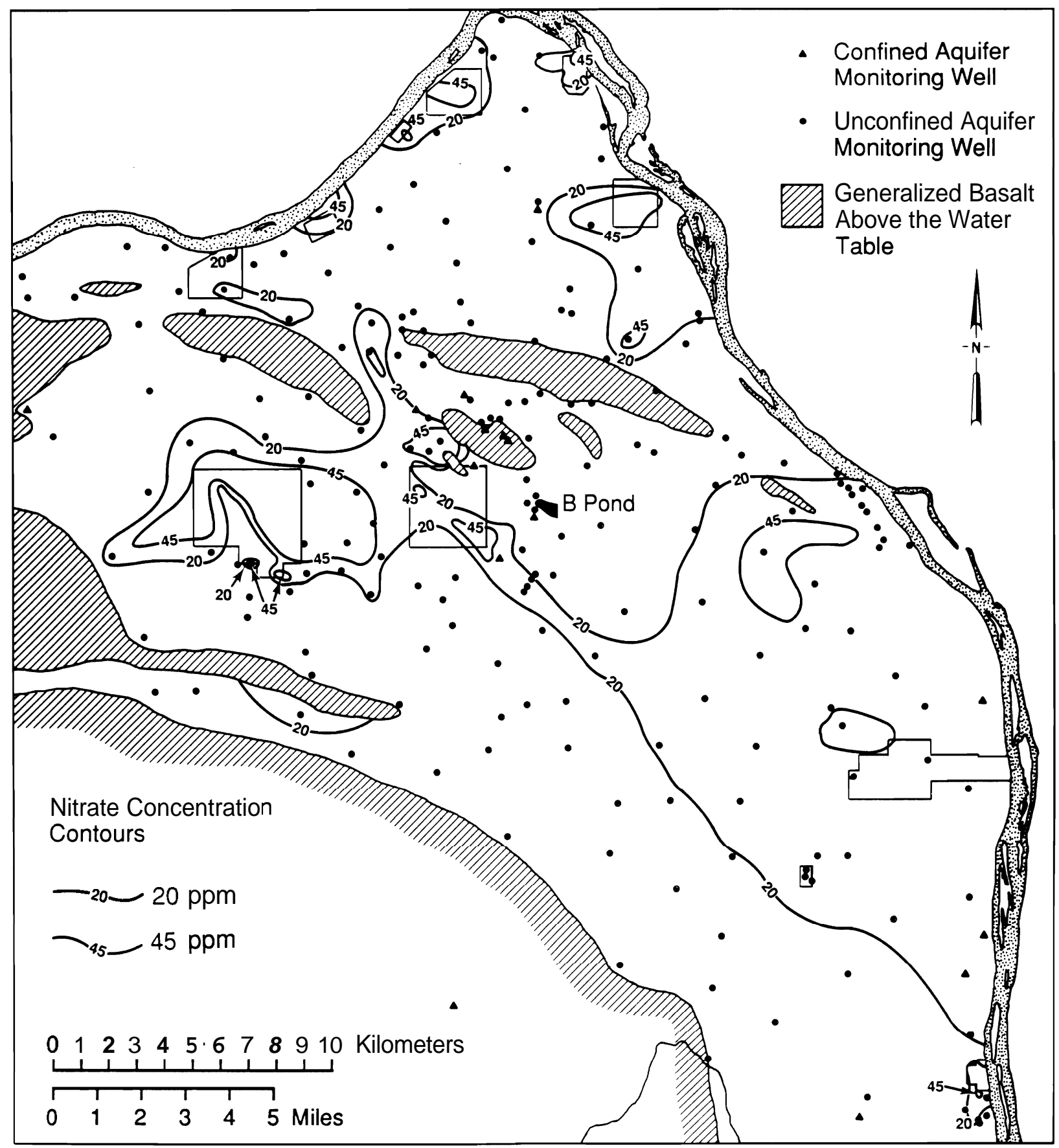

FIGURE 4.10. Nitrate Concentration in the Hanford Site Unconfined Aquifer in 1988 (PNL 1989a) 
Groundwater analyses are compared to EPA Drinking Water Standards and DOE Derived Concentration Guides. The use of Drinking Water Standards is only for reference. The nearest community public drinking water source where the standards apply is for the Columbia River at the city of Richland. In general, radionuclides in groundwater, including gross alpha, gross beta, tritium, cobalt-60, strontium-90, technitium-99, ruthenium-106, iodine-129, and iodine-131 were above the Drinking Water Standards in the immediate vicinity of the operational areas. Only tritium in the 200 Areas and strontium-90 in the 100-N Area were above the Derived Concentration Guides. Tritium continued to move with the groundwater and discharge to the Columbia River.

Monitoring results also indicate that certain chemicals subject to regulation in drinking water by $\mathrm{EA}$ and the State of Washington are present in the groundwater near the operating areas at the Hanford Site (PNL 1989a). Nitrate concentrations resulting from operations exceeded the Drinking Water Standards in parts of the 100, 200, and 300 Areas and in the 600 Area southwest of the old Hanford townsite. Chromium concentrations were above the Drinking Water Standards at $100-\mathrm{H}, 100-\mathrm{D}$, and the surrounding area. Cyanide was observed in and north of the 200-East Area. Fluoride was above the Drinking Water Standards in a few wells in the 200-West Area. Several organic chemicals, primarily carbon tetrachloride, were above the Drinking Water Standards in wells in the 200-West Area. Details of the monitoring program and the results of analyses can be found in PNL (1989a). 


\section{$5.0 \quad \underline{E C O L O G Y}$}

Few site-specific ecological data are available for the proposed NPR site; thus, most of the information presented in this section pertains to the Hanford Site in general but is broadly applicable to the NPR site. Sitespecific data are given where avail able.

The Hanford Site is a relatively large, undisturbed area $\left(1,450 \mathrm{~km}^{2}\right)$ of shrub-steppe desert that contains numerous plant and animal species adapted to the region's semiarid environment. The site consists of mostly undeveloped land with widely spaced clusters of industrial buildings located along the western shoreline of the Columbia River and at several locations in the interior of the site. The industrial buildings are interconnected by roads, rail roads, and electrical transmission lines. The major faci 7 ities and activities, which are shown in Figure 5.1, occupy about 6\% of the total available land area, and their impact to the surrounding ecosystems is minimal. Most of the Hanford Site has not experienced tillage or livestock grazing since the early 1940s. The Columbia River flows through the Hanford Site, and although the river flow is not directly impeded by artificial dams within the Hanford Site, the historical daily and seasonal water fluctuations have been changed by dams upstream and downstream of the site (Rickard and Watson 1985). The Columbia River and other water bodies on the Hanford Site provide habitat for aquatic organisms. These habitats are discussed in detail in Section 5.2. The Columbia River is also accessible for public recreational use and commercial navigation. Other descriptions of the ecology of the Hanford Site can be found in ERDA (1975), Rogers and Rickard (1977), Jamison (1982), and Watson et a1. (1984), among others.

\subsection{TERRESTRIAL ECOLOGY}

\subsubsection{Veqetation}

The Hanford Site, located in southeastern Washington, has been botanically characterized as a shrub-steppe (Daubenmire 1970). Because of the aridity, the productivity of both plants and animals is relatively low compared with other natural communities. In the early 1800 s, the dominant plant 


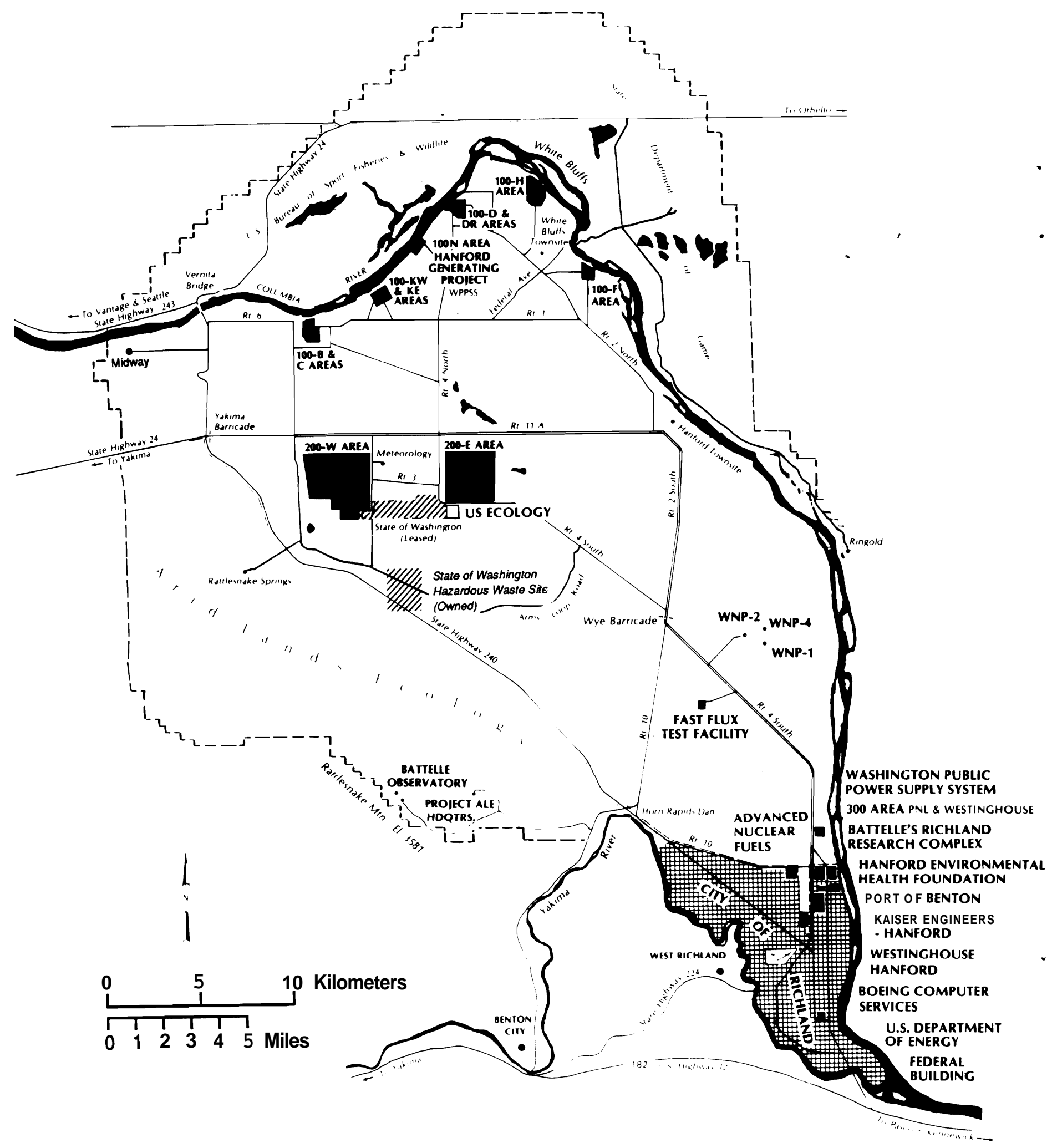

FIGURE 5.1. Major Facilities and Activities at Hanford 
in the area was big sagebrush with an understory of perennial bunchgrasses, especially Sandberg's bluegrass and bluebunch wheatgrass. With the advent of settlement that brought livestock grazing and crop raising, the natural vegetation mosaic was opened to a persistent invasion by alien annuals, especially cheatgrass. Today cheatgrass is the dominant plant on fields that were cultivated 40 years ago. Cheatgrass is also well established on rangelands at elevations less than $244 \mathrm{~m}$ (Rickard and Rogers 1983). Wildfires in the area are common; the most recent extensive fire in 1984 significantly altered the shrub component of the vegetation. The dryland areas of the Hanford Site were treeless in the years before land settlement; however, for several decades before 1943, trees were planted and irrigated on most of the farms to provide windbreaks and shade. When the farms were abandoned in 1943, some of the trees died but others have persisted, presumably because their roots are deep enough to contact groundwater. Today these trees serve as nesting platforms for several species of birds, including hawks, owls, ravens, magpies, and great blue herons, and as night roosts for wintering bald eagles (Rickard and Watson 1985). Today, the vegetation mosaic of the Hanford Site consists of eight major kinds of plant communities:

- sagebrush/bluebunch wheatgrass

- sagebrush/cheatgrass or sagebrush/Sandburg's bluegrass

- sagebrush-bitterbrush/cheatgrass

- greasewood/cheatgrass-saltgrass

- winterfat/Sandberg.s bluegrass

- thyme buckwheat/Sandberg.s bluegrass

- cheatgrass-tumble mustard

- willow.

The distribution of the dominant plant communities is shown in Figure 5.2, and a list of common plants is given in Table 5.1.

The release of water used as industrial process coolant streams at the Hanford Site facilities has created several semipermanent artificial ponds that never existed before these industrial releases commenced. Over the 


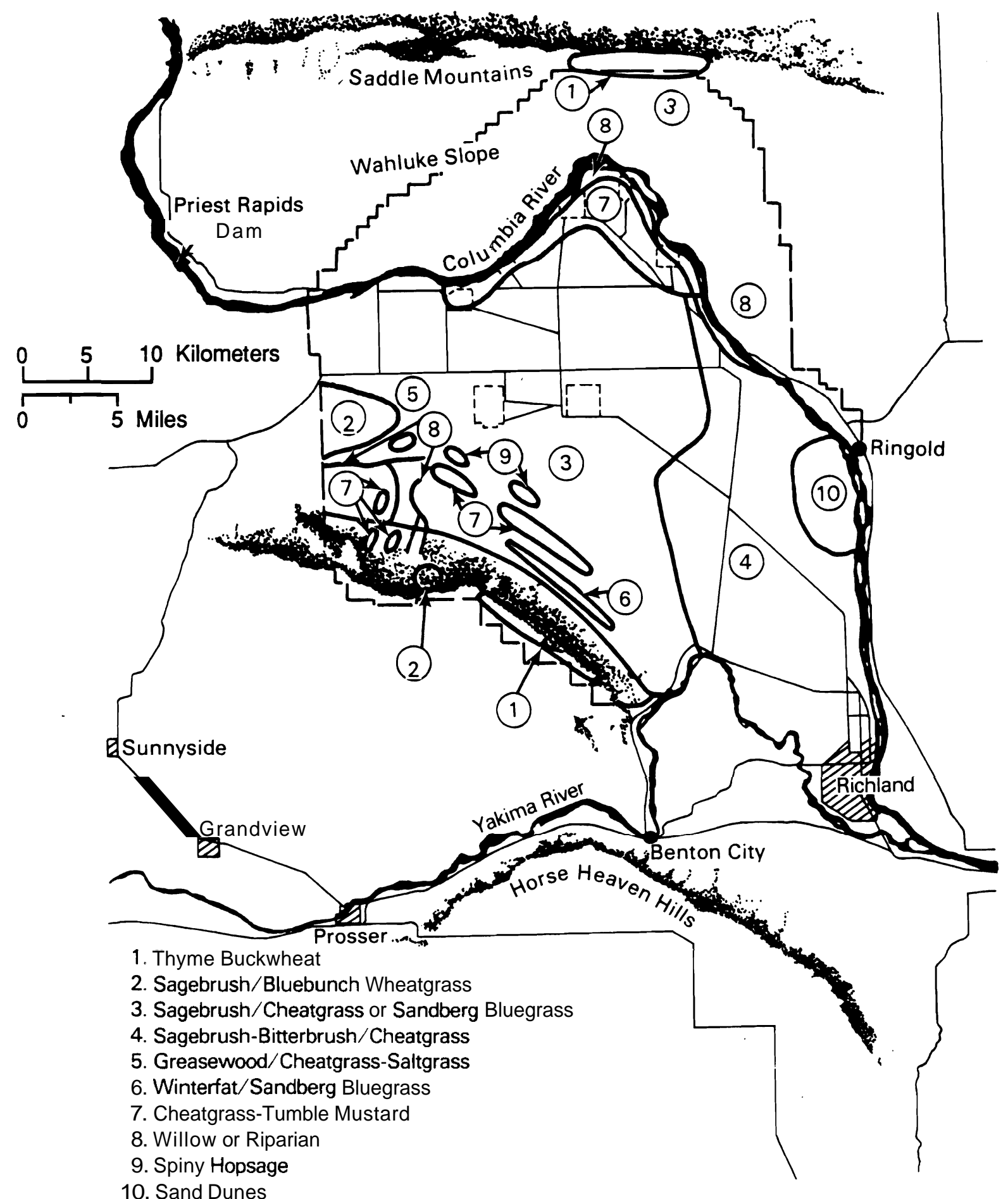

FIGURE 5.2. Distribution of Vegetation Types on the Hanford Site 
TABLE 5.1. Prominent Vegetation on the Hanford Site

Shrubs

Big sagebrush

Spiny hopsage

Grey rabbitbrush

Green rabbitbrush

Bitterbrush

Snowy buckwheat

Perennial grasses

Sandberg's bl uegrass

Needle and thread

Indian ricegrass

Crested wheatgrass

Thick-spike wheatgrass

Sand dropseed

Perennial forbs

Turpentine cymopterus

Comandra

Scurf pea

Pale evening primrose

Cluster lily

Yellow bell

Sandwort

Long-1 eaved phlox

Thelypody

Bal samroot

Cusick's sandflower

Desert mallow

Beard's tongue

Sand dock

Yarrow

Gray cryptantha

Mi 1 kvetch

Annual forbs

Jim Hill (tumble) mustard

Tansy mustard

Spring draba

Microsteris

Matted cryptantha

Hawk's beard

Hoary aster

Western wall flower

Jagged chickweed

Pol emoni um

Blazing star

Phacelia

Yellow salsify
Artemisia tridentata (a)

Grayia (Atriplex) spinosa (a)

Chrvsothamnus nauseous (a)

Chrysothamnus viscidiflorus (a)

Purshia tridentata (a)

Eriogonum niveum (a)

Poa sandbergji (secunda)

(a)

Stipa comata $(a)$

Oryzopsis hymenoides (a)

Aqropyron desertorum (cristatum) (b)

Agropyron dasystachyum (a)

Sporobol us cryptandrus

Cymopterus terebinthïnus (a)

Comandra umbel lata (a)

Psoralea lanciniata (a)

Denothera pallida. (a)

Brodiaea douqlasii (a)

Frittillaria pudica (a)

Arenaria fran'kilinij

Phlox lonaifolia (a)

Thelvpodium lanciniatum

Balsamorhiza carevana (a)

Helianthus cusickii

Sphaeralcea munroana (a)

Penstemon acuminatus $(a)$

Rumex venosus (a)

Achil lea mill efol ium (a)

Crvptantha leucopheea

Astraqal us spei rocarpus (a)

Sisymbrium altissimum (b)

Descurainia pinnata $(a)$

Draba yerna $(a, b)$

Microsteris gracillis (a)

Crvptantha circumscissa (a)

Crepis atrabarba

Aster canescens (a).

Erysimum asperum (

Hol os teum umbel latum $(a, b)$

Pol emoni um mi cranthum (a)

Mentzelia albicaulis

Phacelia linearis (a)

Traqopoqon dubius $(a, b)$ 
TABLE 5.1. (contd)

Annual forbs

Russia thistle (tumbleweed)

$\mathrm{Pl}$ antago

Purple mustard

False yarrow

Cryptantha

Willow-herb

Plectritis

Ragweed

Prickly lettus

Filaree (Crane's bill)

Annual grasses

Cheatgrass

Six-weeks fescue

Pacific fescue

Trees and shrubs

Black Cottonwood

Sand bar willow

Peachleaf willow

Willow

Mulberry

Dogbane

Herbs

Reed canary grass

Cattail

Reeds

Tickseed

Golden aster

Gumweed

Goldenrod

Absinthe

Horsetai 1

Gaillardia

Lupine

Smartweed

Sedge

W iregrass

Speedwell

Wild onion

Russian knapweed

Persistent sepal yellow cress

Watercress

Duckweed (contd)

Salsoa kaلi $(a, b)$

Plantaqo purshii (a)

Chorispora tenel $7 a(a, b)$

Chaenactis douqlasii

Cryptantha pterocarya

Epilobium paniculatum (a)

Plectritis macrocera

Ambrosia à anthicarpa

Lactuca snnniB]ala fo

Erodium cicutarium $(a, b)$

Bromus tectorum $(a, b)$

Festuca octof́lora (a)

Festuca parcififica

Populus trichocarpa

Salix exisua

Salix amyqdaloides

Salix spp

Morus sp. (b)

Apocynum sp.

Phal aris arundinacea

Typha latifolia

Scirpus spp.

Coreopsis atkinsonia

Chrvsopsis oreqana

Grindelia sp.

Solidago occidental is

Artemisia absinthium

Equisetum arvense

Gaillardia aristata

Lupinus spp.

Polvqonum amphibium

Carex spp.

Eleocharis spp.

Veronica anaqall is-aquatica

Allium spp.

Centurea repens (b)

Rorippa columbiae

Rorippa nasturtium-aquatica

Lemna spp.

(a) Likely to occur at the proposed NPR site.

(b) Exotic. 
years, stands of cattails, reeds, and trees, especially willow, cottonwood, and Russian olive, have developed around the ponds. These ponds are ephemeral and will disappear if the industrial release of water is terminated.

Over 240 species of plants have been identified on the Hanford Site (ERDA 1975). The dominant plants on the 200-Area Plateau, including the proposed NPR site, are big sagebrush, rabbitbrush, cheatgrass, and Sandberg's bluegrass, with cheatgrass providing half of the total plant cover. Cottonwood, willows, cattails, and bullrushes grow along the banks of ponds and ditches. Near the 100 Areas, cheatgrass and riparian plants are the most prevalent, and big sagebrush, bitterbrush, rabbitbrush, cheatgrass, and Sandberg's bluegrass are common in the 300 and 400 Areas. Over 100 species of plants have been identified in the 200-Area Plateau (ERDA 1975). Cheatgrass and Russian thistle, which are annuals introduced to the United States from Eurasia in the late 1800 s, invade areas where the ground surface has been disturbed. A food web centered on cheatgrass is shown in Figure 5.3

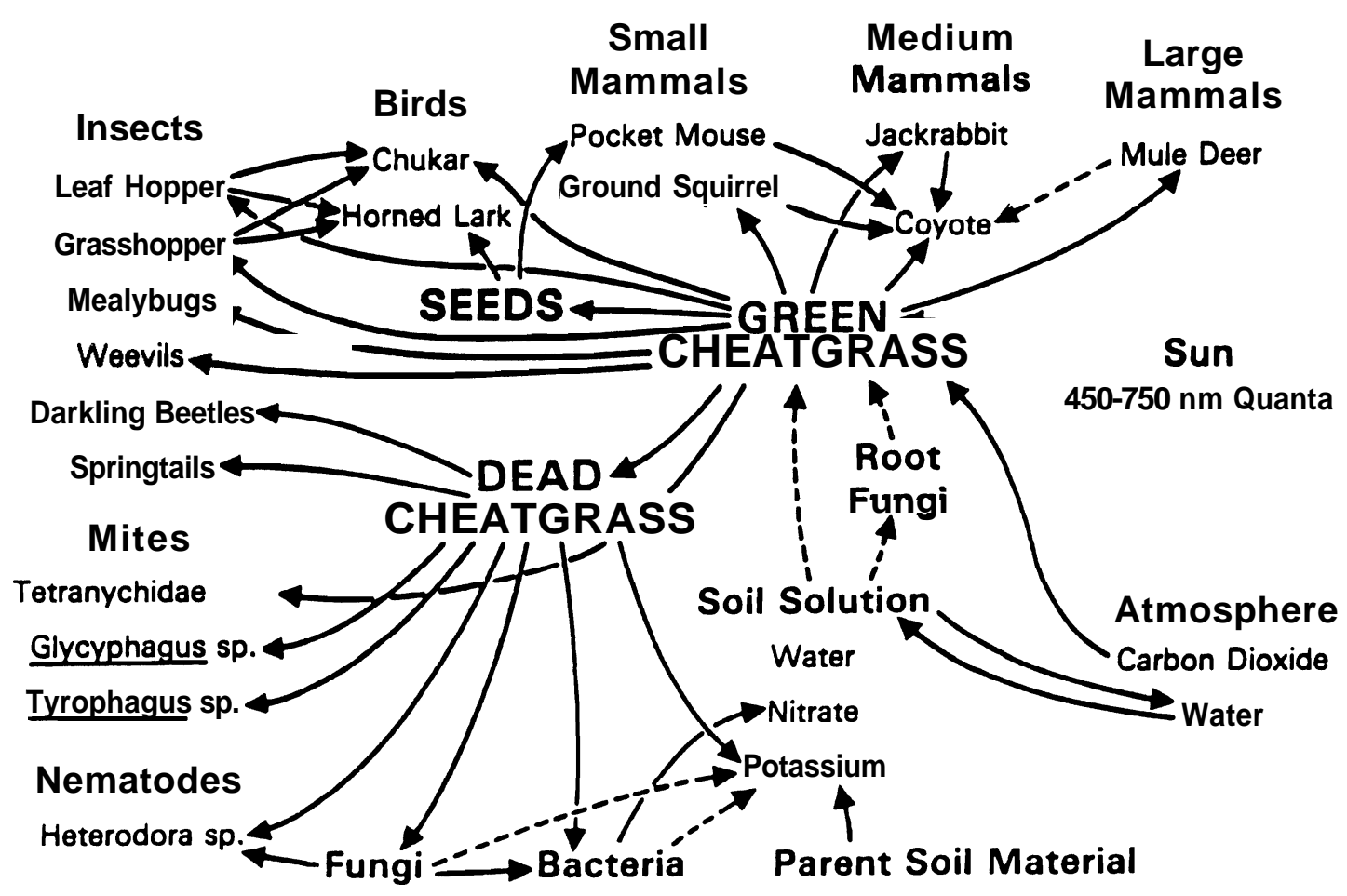

FIGURE 5.3. Food Web Centered on Cheatgrass (arrows indicate direction of energy and mass transfer) 
(modified from Watson et al. 1984). The main links leading to man would be through mule deer and chukar partridge. Certain desert plants have roots that grow to depths approaching $10 \mathrm{~m}$ (Napier 1982); however, root penetration to these depths has not been demonstrated for plants in the 200 Areas. Rabbitbrush roots have been found at a depth of 2.4 m near the 200 Areas (Klepper et al. 1979). Mosses and lichens appear abundantly on the soil surface; lichens commonly grow on the shrub stems.

The land within and adjacent to the NPR site is gently undulating at elevations that range between 122 and $215 \mathrm{~m}$ above mean sea level. The rooting substrate is sandy and susceptible to wind erosion. A large area of unvegetated mobile sand dunes is present along the western shoreline of the Columbia River. Unvegetated blowouts are scattered throughout. Directional movement of the dunes is from west to east towards the Columbia River.

The important desert shrubs, big sagebrush and bitterbrush, are widely spaced and usually provide less than $20 \%$ canopy cover. The important understory plants are grasses, especially cheatgrass, Sandberg's bluegrass, Indian ricegrass, June grass, and needle-and-thread grass.

As compared to other semiarid regions in North America, primary productivity is relatively low and the number of vascular plant species is also low. This is attributed to the low annual precipitation $(16 \mathrm{~cm})$, the low water-holding capacity of the rooting substrate (sand), as well as the droughty summer and occasionally very cold winters.

Sagebrush and bitterbrush are easily killed by summer burning but the grasses and other herbs are relatively resistant and they usually recover in the first growing season after burning. Burning usually opens the community to wind erosion. The severity of erosion depends upon the severity and areal extent of the burn. Hot burns incinerate entire shrubs and damage grass crowns. Less intensive burns leave standing dead stems and recovery of herbs is prompt. The most recent and extensive wildfire occurred in the summer of 1984.

Bitterbrush shrubs provide browse for a resident herd of wild mule deer. Bitterbrush shrubs are slow to recolonize burned areas because invasion is by 
seeds. Bitterbrush does not sprout even when burn damage is relatively light. Recent wildfires have removed much of the mule deer browse from the NPR site.

Cheatgrass is the most prolific seed producer in the vegetation at the NPR site and the seeds are eaten by pocket mice, which are the most abundant mammal at the site (Gano and Rickard 1982).

Certain passerine birds rely upon sagebrush and/or bitterbrush for nesting (i.e., sage sparrow, sage thrasher, and loggerhead shrike). These birds are not expected to nest in places devoid of shrubs. Jackrabbits also appear to avoid burned areas without shrubs. Birds that nest on the ground in areas without shrubs are longbilled curlews, horned larks, Western meadowlarks, and burrowing owl s.

\subsubsection{Insects}

More than 300 species of terrestrial and aquatic insects have been found on the Hanford Site (ERDA 1975). Grasshoppers and darkling beetles are among the more conspicuous groups and, along with other species, are important in the food web of the local birds and mammals. Most species of darkling beetles occur throughout the spring to fall period, although some species are present only during 2 or 3 months in the fall (Rogers and Rickard 1977). Grasshoppers are evident during the late spring to fall. Both groups are subject to wide annual variations in abundance. A food web centered on grasshoppers is shown in Figure 5.4 (Watson et al. 1984). The link leading to the Swainson's hawk is of concern in this case, because it is a federal candidate species.

\subsubsection{Reptiles and Amphibians}

Approximately 16 species (Table 5.2) of amphibians and reptiles have been observed at the Hanford Site (ERDA 1975). The occurrence of the species is infrequent when compared with the similar fauna of the southwestern United States. The side-blotched lizard is the most abundant reptile and can be found throughout the Hanford Site. Horned and sagebrush 1izards are also common. Short-horned and sagebrush lizards are also common in selected habitats. The most common snakes are the gopher snake, the yellow-bellied 


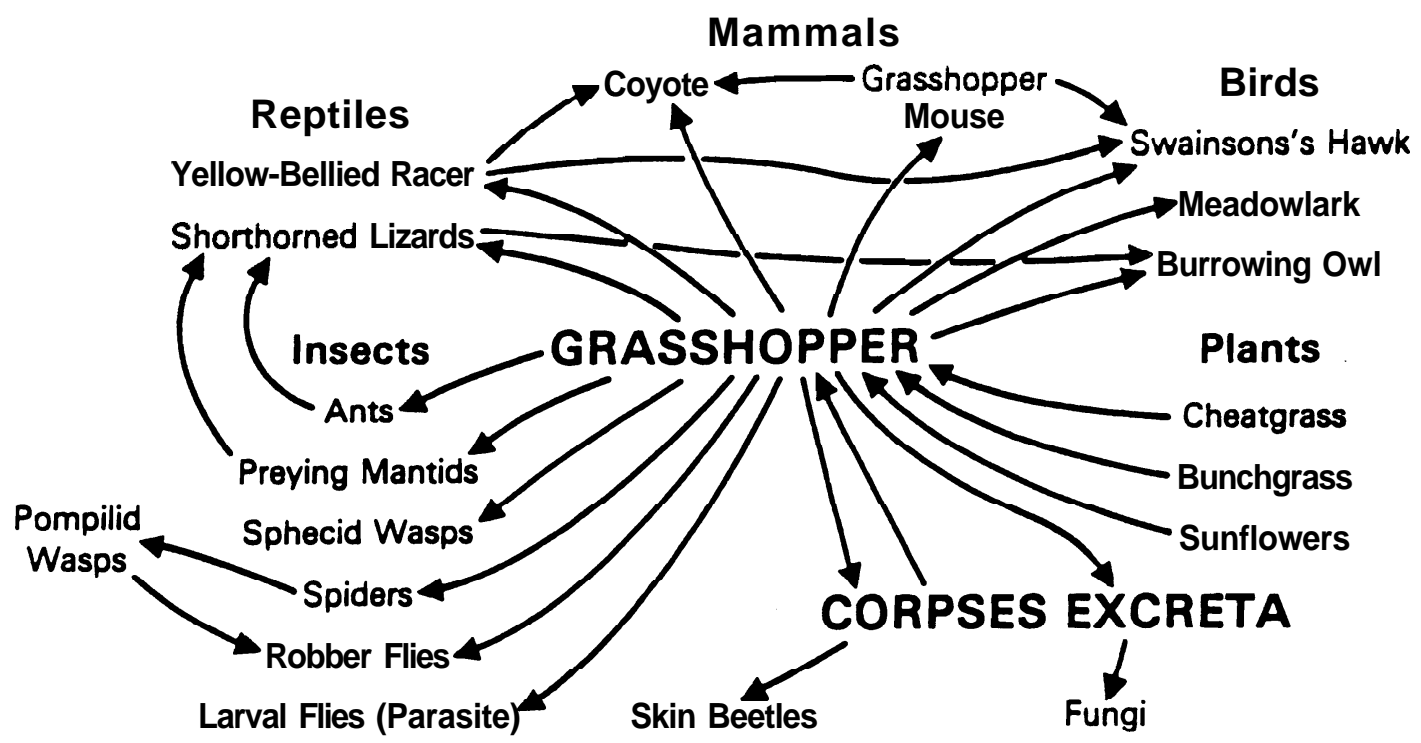

FGGURE 5.4. Food Web Centered on Grasshoppers (arrows indicate direction of energy and mass transfer)

racer, and the Pacific rattlesnake, which are found throughout the Hanford Site. Striped whipsnakes and desert night snakes are rarely found, but some records of sightings are available for the site. Toads and frogs are found near the permanent water bodies and along the Columbia River.

\subsubsection{Birds}

Over 125 species of birds have been identified at the Hanford Site (Rogers and Rickard 1977). The horned lark and western meadowlark are the most abundant nesting birds in the shrub-steppe. Some of the more common birds present on the Hanford Site are listed in Table 5.3.

The Hanford Site supports populations of chukar partridge, gray partridge, and sage grouse. The greatest concentrations of these birds are in the Rattlesnake Hills. The sage grouse population is very small and appears to be confined entirely to the slopes of the Rattlesnake Hills. The mourning dove nests throughout the Hanford Site. Small isolated populations of Chinese ring-necked pheasants and California quail live along the Columbia River and near the spring-streams in the Rattlesnake Hills. A food web centered on chukar partridge is shown in Figure 5.5 (Watson et al. 1984). Chukar partridge are hunted and eaten by humans so this link is of concern. 
TABLE 5.2. Amphibians and Reptiles Occurring on the Hanford Site

\begin{tabular}{|c|c|}
\hline Common Name & Scientific Name \\
\hline \multicolumn{2}{|l|}{ Amphibians } \\
\hline Great Basin spadefoot toad & Spea intermontanus $(a)$ \\
\hline Western toad & Bufo boreas \\
\hline Woodhouse toad & $\underline{B u f o}$ woodhousei i $\left({ }^{\mathrm{a}}\right)$ \\
\hline Pacific treefrog & Hyla reqilla \\
\hline Bull frog & $\underline{\text { Rana catesbeiana }}$ \\
\hline \multicolumn{2}{|l|}{ Repti les } \\
\hline Sagebrush lizard & $\underline{\text { Sceloporus qraciosus }}(\mathrm{a})$ \\
\hline Side-blotched lizard & $\underline{\text { Uta stansburiana }}(\mathrm{a})$ \\
\hline Short-horned lizard & $\underline{\text { Phrvnosoma douqlassi i }}(\mathrm{a})$ \\
\hline Striped whipsnake & Masticophis taeniatus $(a)$ \\
\hline Western yellow-be11ied racer & Coluber constrictor $(a)$ \\
\hline Gopher snake & $\underline{\text { Pituophis melanoleucus }}$ (a \\
\hline Western terrestrial garter snake & $\underline{\text { Thamnophis }} \underline{\text { eleqans }}$ \\
\hline Common garter snake & Thamnophis sirtalis \\
\hline Desert night snake & Hyspiqlena torquata $(a)$ \\
\hline Pacific rattlesnake & Crotal us viridis $(a)$ \\
\hline
\end{tabular}

(a) Likely to occur on the proposed NPR site.

Wastewater ponds at the Hanford Site are important habitats for songbirds, shore birds, ducks, and geese (Fitzner and Price 1973; Fitzner and Rickard 1975; Fitzner and Schreckhise 1979). The American coot is an abundant aquatic nesting bird on these sites. The ponds are used by a variety of waterfowl during fall migration. The most important resident waterfowl is the Canada goose, whose nesting habitat is confined to the islands of the free-flowing reach of the Columbia River (Hanson and Eberhardt 1971). Forester's tern, ring-billed gulls, and California gulls also nest on the islands. The Columbia River also serves as a major resting area for migrant waterfowl. The greatest concentrations of ducks and geese occur in the autumn months, and waterfowl hunting is a popular recreational activity where 
TABLE 5.3. Partial List of the Birds Found on the Hanford Site

Common Name

Great blue heron
Canada goose
Mallard
Red-tailed hawk
Swai nson's hawk
Rough-1egged hawk
Sage grouse
Cal ifornia quail
Ring-necked pheasant
Chukar partridge
Gray (Hungarian) partridg
American coot
Cal ifornia gull
Ring-bi 1 led gull
Mourning dove
Horned lark
Black-billed magpie
Western meadowlark
Sage sparrow

Scientific Name

$\underline{\text { Ardea herodias }}$

Branta canadensis moffitt i

Anas platyrhynchos

Buteo jamaicensis (a)

Buteo swainsoni (a)

Buteo laqopus (a)

Centrocereus urophasianus

Call ipepla cal ifornicus

Phasianus colchicus

Alectoris chukar (a)

$\underline{\text { Perdix perdix }}$

Fulica americana

Larus californicus (a)

Larus delawarensis $(a)$

Zenaidura macroura $(a)$

Eremophila alpestris (a)

Pica pica (a)

Sturnella neqlecta (a)

Amphispiza be11i(a)

(a) Likely to occur on the proposed NPR site.

it is permitted. The Hanford Site is located in the Pacific Flyway; in addition, a major sandhill crane flyway passes over the site.

Hawks and owls use the Hanford Site as a refuge, especially during nesting (Fitzner et al. 1980).

\subsubsection{Mammal s}

Approximately 30 species of mammals have been identified on the Hanford Site (Table 5.4). Most are small and nocturnal. Of this group, the Great Basin pocket mouse is the most abundant; other species include the deer mouse, Townsend's ground squirrel, Northern pocket gopher, Western harvest 


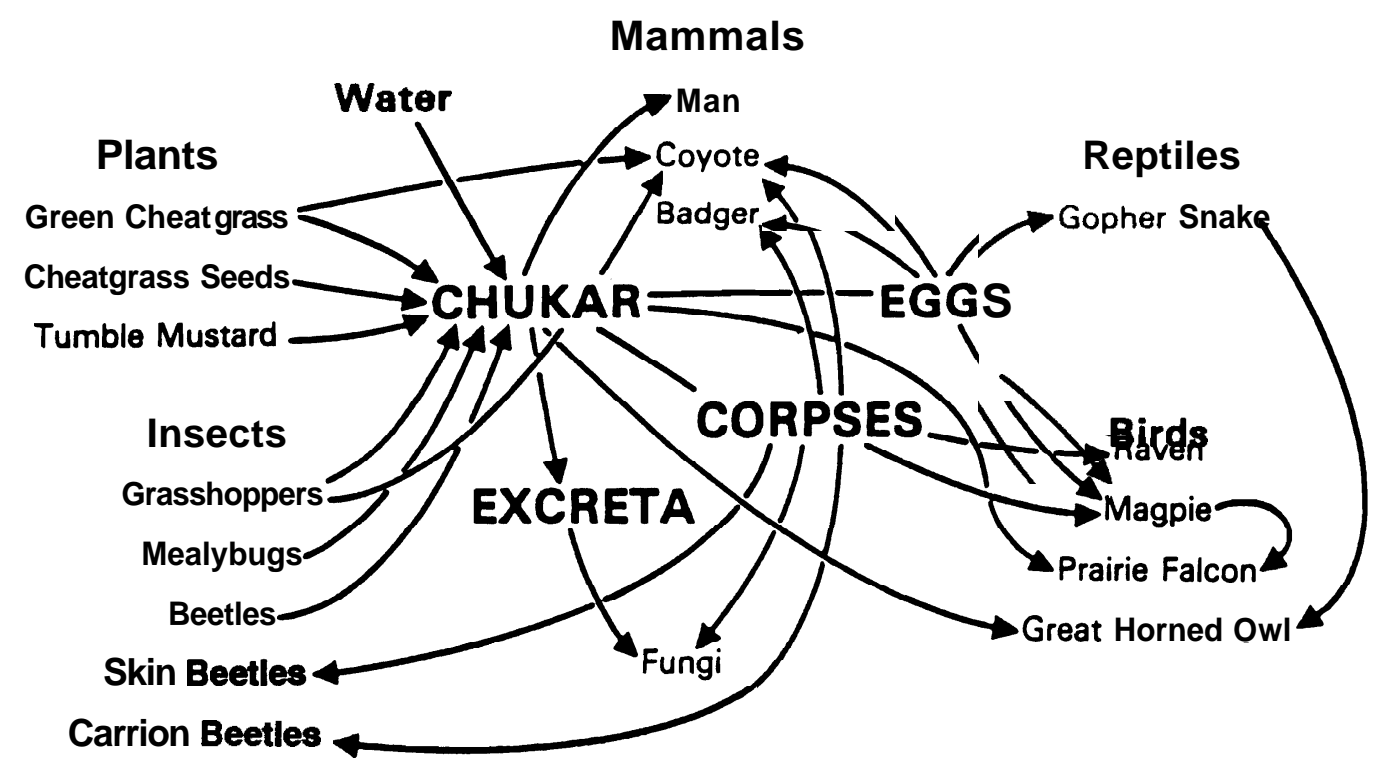

FGURE 5.5. Food Wab Centered on Chukar Partridge (arrows indicate direction of energy and mass transfer)

mouse, house mouse, Norway rat, sagebrush vole, grasshopper mouse, vagrant shrew, least chipmunk, and Merriam's shrew. Nuttall's cottontail rabbits are widely distributed throughout the dryland habitats of the Hanford Site, and the black-tailed jackrabbit is found scattered throughout the lower elevations.

Muskrats and porcupines have been observed along the shorelines of streams, ponds, and ditches, and beavers are residents of the sloughs along the Columbia River. Raccoons, skunks, bobcats, mink, and badgers are also present on the site. The coyote is the principal mammalian predator on the site.

Larger mammals found include the mule deer and elk. The herd of elk is centered almost entirely on the Arid Lands Ecology (ALE) reserve, a part of the Hanford Site established as an environmental research study area in 1968. The mule deer are found mostly along the Columbia River and in the Rattlesnake Hills, although they move throughout the site.

Seven species of bats are also present on the Hanford Site. 
TABLE 5.4. List of Mammals Occurring on the Hanford Site

Common Name

Merri am's shrew

Vagrant shrew

Little brown bat

Si †ver-haired bat

California brown bat

Yuma brown bat

Big brown bat

Pallid bat

Hoary bat

Raccoon

Mink

Long tailed weasel

Short-tai7ed weasel

Badger

Striped skunk

Coyote

Bobcat

Least chipmunk

Yell ow-be17ied marmot

Townsend's ground squirrel

Northern pocket gopher

Great Basin pocket mouse

Beaver

Western harvest mouse

Deer mouse

Northern grasshopper mouse

Montane meadow mouse

Bushy-tailed woodrat

Sagebrush vole

Muskrat

House mouse

Norway $r$ at
Scientific Name

Sorex merriami

$\underline{\text { Sorex vaqrans }}$

Mvotis lucifuqus (a)

Lasionvcteris noctivaqans (a)

Mvotis californicus (a)

Mvotis yumanensis (a)

Eptesicus fuscus

Antrozous pal lidus (a)

Lasiurus cinereus

Procvon lotor

Mustela vison

Mustela frenata

Mustela ermineu

Taxidea taxis $(a)$

Mephitis mephitis

Canis Tatrans (a)

Lynx rufus (a)

Eutamias minimus

Marmota flaviventris

Spermophilus townsendi i (a)

Thomomys tal poides (a)

Peroqnathus parvus (a)

Castor canadensis

Reithrodontomvs meqalotis (a)

Peromyscus maniculatus (a)

Onychomys leucogaster (a)

Microtus montanus

Neotoma cinerea (a)

Laqurus curtatus

Ondatra zibethicus

Mus musculus

Rattus norveqicus 
TABLE 5.4. (contd)

\begin{tabular}{|c|c|}
\hline Common Name & Scientific Name \\
\hline Porcupine & Erethizon dorsatum (a) \\
\hline Black-tailed jackrabbit & Lepus californicus (a) \\
\hline White-tailed jackrabbit & Lepus townsendi \\
\hline Nuttall's cottontail rabbit & Sylvilaqus nuttalliii (a) \\
\hline Mule deer & $\underline{\text { Odocoileus hemionus }}^{(a)}$ \\
\hline White-tailed deer & Odocoileus virginianus \\
\hline Elk & Cervus elaphus \\
\hline
\end{tabular}

(a) Likely to occur on the proposed NPR site.

\subsection{AQUATIC ECOLOGY}

There are no surface water bodies on the proposed NPR site.

There are two types of natural aquatic habitats on the Hanford Site; one is the Columbia River, which flows along the northern and eastern edges of the Hanford Site, and the other is the small spring-streams and seeps located mainly on the ALE site in the Rattlesnake Hills. Several artificial water bodies, both ponds and ditches, have been formed as a result of wastewater disposal practices associated with the operation of the reactors and separation facilities. These are temporary and will vanish with cessation of activities, but while present, they form established aquatic ecosystems (except West Pond) complete with representative flora and fauna. West Pond is created by a rise in the water table in the 200 Areas and is not fed by surface flow; thus, it is alkaline and has a much restricted complement of biota.

\subsubsection{The Columbia River}

The Columbia River is the dominant aquatic ecosystem on the Hanford Site and supports a large and diverse community of plankton, benthic invertebrates, fish, and other communities. It is the fifth largest river in North America and has a total length of about 2,000 km from its origin in British Columbia to its mouth at the Pacific Ocean. The Columbia River has been dammed both upstream and downstream from the Hanford Site, and the reach 
flowing through the area is the last free-flowing, but regulated, reach of the Columbia in the United States. Plankton populations in the Hanford reach are influenced by communities that develop in the reservoirs of upstream dams, particularly Priest Rapids Reservoir, and manipulation of water levels below by dam operations in downstream reservoirs. Phytoplankton and zooplankton populations at Hanford are largely transient, flowing from one reservoir to another. There is generally insufficient time for characteristic endemic groups of phytoplankton and zooplankton to develop in the Hanford reach. N tributaries enter the Columbia during its passage through the Hanford Site.

The Columbia River is a very complex ecosystem because of its size, the number of manmade alterations, the diversity of the biota, and the size and diversity of its drainage basin. Streams in general, especially smaller ones, usually depend upon organic matter from outside sources (terrestrial plant debris) to provide energy for the ecosystem. Large rivers, particularly the Columbia River with its series of large reservoirs, contain significant populations of primary energy producers (algae, plants) that contribute to the basic energy'requirernents of the biota. Phytoplankton (free-floating algae) and periphyton (sessile algae) are abundant in the Columbia River and provide food for herbivores such as immature insects, which in turn are consumed by carnivorous species. Figure 5.6 is a simplified diagram of the food-web relationships in selected Columbia River biota and represent probable major energy pathways.

\subsubsection{Phytoplankton}

Phytoplankton species identified from the Hanford reach include diatoms, golden or yellow-brown algae, green algae, blue-green algae, red algae, and dinoflagellates. Diatoms are the dominant algae in the Columbia River phytopl ankton, usually representing over $90 \%$ of the populations. The main genera include Asterionel 1a, Cyclotella, Fraqilaria, Melosira, Stephanodiscus and Svnedra (Neitzel et al. 1982a). These are typical of those forms found in lakes and ponds and originate in the upstream reservoirs. A number of algae found as free-floating species in the Hanford reach of the Columbia River are actually derived from the periphyton; they are detached and 


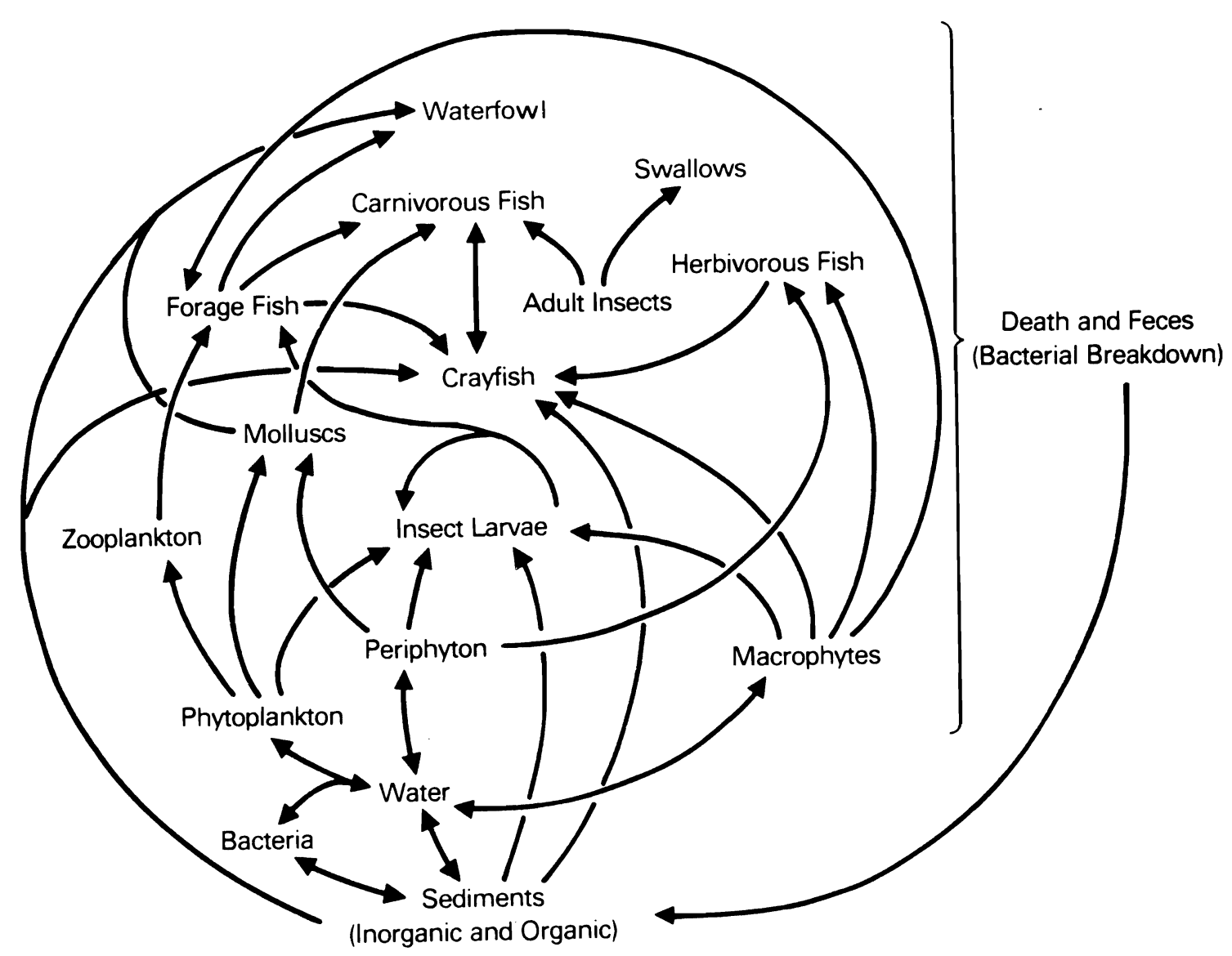

FIGURE 5.6. Food Web in the Columbia River

suspended by the current and frequent fluctuations of the water level. The peak concentration of phytoplankton is observed in April and May, with a secondary peak in late summer/early autumn (Cushing 1967a). The spring pulse in phytoplankton density is probably related to increasing light and water temperature rather than to availability of nutrients because phosphate and nitrate nutrient concentrations are never limiting. Minimum numbers are present in December and January. Green algae (Chl oroplyta) and bl ue-green algae (Cyanophyta) occur in the phytoplankton community during warmer months, but in substantially fewer numbers than the diatoms. Diversity indices, carbon uptake, and chlorophyll a concentrations for the phytoplankton at various times and places can be found in Wolf et al. (1976), Beak Consultants Inc. (1980), and Neitzel et al. (1982a). 


\subsubsection{Periphyton}

Communities of periphytic species ("benthic microflora") develop on suitable solid substrates wherever there is sufficient light for photosynthesis. Peaks of production occur in spring and late summer (Cushing 1967b). Dominant genera are the diatoms Achnanthes, Asterionella, Cocconeis, Fraqillaria, Gomohonema, Melosira, Nitzchia, Stephanodiscus and Svnedra (Page and Nei tzel 1978, Page et a1. 1979, Beak Consultants Inc. 1980, Neitzel et al. 1982a).

\subsubsection{Macrophvtes}

Macrophytes are sparse in the Columbia River due to the strong currents, rocky bottom, and frequently fluctuating water 1evels. Rushes (Juncus spp.) and sedges (Carex spp.) occur along the shorelines of the slackwater areas such as the White Bluffs Slough, below 100-H Area, the slough area downstream of the 100-F Area, and the Hanford Slough. Macrophytes are also present along gently sloping shorelines that are subject to flooding during the spring freshet and daily fluctuating river levels (below Coyote Rapids and the 100-D Area). Commonly found plants include Lemna, Potamoqeton, Elodea, and Myriophyllum. Where they exist, macrophytes have considerable ecological value. They provide food and shelter for juvenile fish and spawning areas for some species of warm-water game fish.

\subsubsection{Zooplankton}

The zooplankton populations in the Hanford reach of the Columbia are generally sparse. In the open water regions, crustacean zooplankters are dominant. Dominant genera are Bosmina, Diaptomus, and Cvclops. Densities are lowest in winter and highest in the summer. Summer peaks are dominated by Bosmina and range up to 4,500 organisms $/ \mathrm{m}^{3}$. Winter densities are general ly less than 50 organisms $/ \mathrm{m}^{3}$. Daptomus and $\underline{\mathrm{Cvcl} o p s}$ dominate in winter and spring, respectively (Neitzel et al. 1982b).

\subsubsection{Benthic Oraanisms}

Benthic organisms are found either attached to or closely associated with the substrate. All major freshwater benthic taxa are represented in the Columbia River. Insect larvae such as caddisflies (Trichoptera), midge flies 
(Chironomidae), and black flies (Simuliidae) are dominant. Dominant caddisfly species are Hydropsyche cockerelli, Cheumatopsyche campyla and 6. enonis. Other benthic organisms include limpets, snails, sponges, and crayfish. Peak larval insect densities are found in late fall and winter, and the major emergence is in spring and summer (Wolf 1976). Stomach contents of fish collected in the Hanford reach from June 1973 through March 1980 revealed that benthic invertebrates are important food items for nearly all juvenile and adult fish. There is a close relationship between food organisms in the stomach contents and those in the benthic and invertebrate drift communities.

\subsubsection{Fish}

Gray and Dauble (1977) list 43 species of fish in the Hanford reach of the Col umbia River. Since 1977, the brown bull head (Ictalurus nebulosus) has been collected bringing the total number of fish species identified in the Hanford reach to 44 (Table 5.5). Of these species, the chinook salmon, sockeye salmon, coho salmon, and steel head trout use the river as a migration route to and from upstream spawning areas and are of the greatest economic importance. Both the fall chinook salmon and steelhead trout also spawn in the Hanford reach. Since 1962, the Hanford reach spawning population has represented about 15 to $20 \%$ of the total fall chinook escapement to the river. The destruction of other mainstream Col umbia spawning grounds by dams has increased the relative importance of the Hanford spawning reach (Watson 1970, 1973).

The annual average Hanford reach steelhead spawning population estimates for the years 1962 to 1971 were about 10,000 fish. The estimated annual sport catch for the period 1963 to 1968 in the reach of the river from Ringold to the mouth of the Snake River was approximately 2,700 fish (Watson 1973).

The shad, another anadromous species, may also spawn in the Hanford reach. The upstream range of the shad has been increasing since 1956 when fewer than 10 adult shad ascended McNary Dam. Since then, the number ascending Priest Rapids Dam, immediately upstream from Hanford, has risen to many thousands each year and the young-of-the-year have been collected in the 
TABLE 5.5. Fish Species in the Hanford Reach of the Columbia River

Common Name

White sturgeon

Bridgelip sucker

Largescale sucker

Mountiin sucker

Pumpkinseed

Bluegill

Smallmouth bass

Largemouth bass

White crappie

Black crappie

American shad

Prickley sculpin

Mottled sculpin

Piute sculpin

Reticulate sculpin

Torrent sculpin

Chiselmouth

Carp

Peamouth

Northern squawfish

Longnose dace

Leopard dace

Speckled dace

Redside shiner

Tench

Burbot

Threespine stickleback

Black bullhead

Yellow bullhead

Brown bullhead

Channel catfish

Yellow perch
Scientific Name

Acipenser transmontanus

Catostomus columbianus

Catostomus macrochei1us

Catostomus platvrhvnchus

Lepomis sibbosus

Lepomis macrochirus

Micropterus dolomieui

Micropterus salmoides

Pomoxis annularis

Pomoxis niqromaculatus

Alosa sapidissima

Cottus asper

Cottus bairdi

Cottus beldinqi

Cottus perplexus

Cottus rotheis

Acrocheilus alutaceus

Cvprinus carpio

Mvlocheilus caurinus

Ptvchocheilus oreqonensis

Rhinichthvs cataractae

Rhinichthvs falcatus

Rhinichthvs osculus

Richardsonius balteatus

Tinca tinca

Lota lota

Gasterosteus aculeatus

Ictalurus melas

Ictalurus natal is

Ictalurus nebulosus

Ictalurus punctatus

Perca flavescens 
TABLE 5.5. (contd)

\begin{tabular}{l} 
Common Name \\
\hline Wall eye \\
Sand roller \\
Pacific lamprey \\
River lamprey \\
Lake whitefish \\
Coho salmon \\
Sockeye salmon \\
Chinook salmon \\
Mountain whitefish \\
Cutthroat trout \\
Rainbow trout (steelhead) \\
Dolly Varden
\end{tabular}

Scientific Name

Stizostedion vitreum vitreum

Percopsis transmontana

Entosphenus tridentatus

Lampetra ayresi

Coreqonus clupeaformis

Oncorhynchus kisutch

Oncorhynchus nerka

Oncorhvnchus tshawytscha

Prosodium williamsoni

Oncorhvnchus $\underline{\text { cl arki }}$

Onorhvnchus mykiss

$\underline{\text { Sal vel inus malna }}$

Hanford reach. The shad is not dependent upon specific current and bottom conditions required by the salmon.ids for spawning and has apparently found favorable conditions for reproduction throughout much of the Columbia River and the Snake River.

Other fish of importance to sport fishermen are the whitefish, sturgeon, smallmouth bass, crappie, catfish, walleye, and perch. Large populations of rough fish including carp, shiners, suckers, and squawfish are also present.

\subsubsection{Spring Streams}

The small spring streams, such as Rattlesnake and Snively Springs, contain diverse biotic communities and are extremely productive (Cushing and Wolf 1984). Dense blooms of watercress occur which are not lost until one of the major flash floods occurs. The aquatic insect production is fairly high as compared to mountain streams (Gaines 1987). The macrobenthic biota varies from site to site and is related to the proximity of colonizing insects and other factors. 


\subsubsection{Temoorary Water Bodies}

The temporary waste-water ponds and ditches have been in place for as long as two decades. Rickard et a1. (1981) discussed the ecology of Gable Mountain Pond, one of the former major Ientic sites. Emery and McShane (1980) presented the ecological characteristics of all of the temporary sites. The ponds develop luxuriant riparian communities and become quite attractive to autumn and spring migrating birds; several species nest in the vicinity of the ponds. Some of these ponds and ditches are shown in Figure 4.1 .

\subsection{THREATENED AND ENDANCER⿴囗十 SPECIES}

Threatened and endangered plants and animals, as listed by the federal government (DOI 1986), Washington State (Washington National Heritage Program 1987), and Dunn, (a) are shown in Table 5.6. There are no plants or mammals,

TABLE 5.6. Threatened ( $T$ ) and Endangered (E) Species

Common Name

Plants

Columbia milk-vetch

Yellowcress

Birds

Peregrine falcon

Bald eagle

White pelican

Sandhi11 crane

Ferruginous hawk
Scientific Name

Federal State

Astraqalus columbianus

Rorippa columbiae

Falco pereqrinus

Hal iaeetus leucocephalus

Pelecanus ervthrorhvchos

Grus canadensis

Buteo reqalis
T $E(a)$

$\begin{array}{cl} & T \\ & E(a) \\ T & E(a) \\ & T^{(a)} \\ & E(a) \\ & E(a) \\ & T^{(a)}\end{array}$

(a) Possible occurrence on the proposed NPR site.

(a) A. Dunn, U.S. Department of the Interior, Fish and Wildlife Service Letter to E. B. Moore, Pacific Northwest Laboratory, September 10, 1987. Subject: Response to 1-3-87-SP-341, a li s t of endangered and threatened species. 
on the federal 1 ist of Endangered and Threatened Wildlife and Plants (50 CFR 17.11 , 17.12) that are known to occur on the Hanford Site. There are, however, several species of both plants and animals that are under consideration for formal listing by the federal government and Washington State.

\subsection{1 $\underline{\text { Plants }}$}

Two species of plants are included in the Washington State 1isting. Columbia milk-vetch (Astraqalus columbianus Barneby) is listed as threatened, and yellowcress (Rorippa col umbiae Suksd.) is designated as endangered. Columbia mil k-vetch occurs on dry land benches along the Columbia River in the vicinity of Priest Rapids Dam, Midway, and Vernita and is unlikely to occur at the proposed NPR site. Yellowcress occurs in the wetted zone of the water's edge along the Col umbia River.

\subsection{2 $\underline{\text { Birds }}$}

The federal government 1 ists the peregrine falcon (Falco peregrinus) as endangered, and the bald eagle (Haliaeetus leucocephalus) as threatened. The State of Washington lists, in addition to the peregrine falcon and bald eagle, the white pelican (Pelecanus ervthrorhvnchos) and sandhi11 crane (Grus

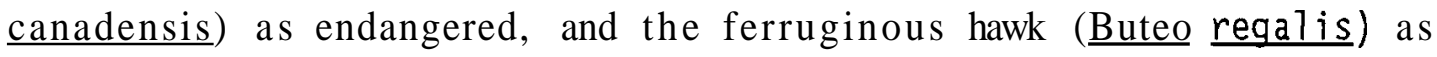
threatened. The peregrine falcon is a casual migrant to the Hanford Site and does not nest here. The bald eagle is a regular winter resident and forages on dead salmon and waterfowl along the Columbia River; it does not nest on the Hanford Site. Increased use of power poles for nesting sites by the ferruginous hawk on the Hanford Site has been noted, particularly in the vicinity of the proposed NPR site. Washington State Bald Eagle Protection Rules were issued in 1986 (WAC 232-12-292). These rules will require DOE to prepare a management plan to mitigate eagle disturbance, to obtain agreement from the Washington State Game Department and may require specific buffer zones in line with U.S. Fish and Wildlife Service guidelines. The Endangered Species Act of 1973 will also require that Section 7 consultation be undertaken when any action is taken that may jeopardize the existence, or destroy, or adversely modify habitat of the bald eagle or other endangered species. 


\subsubsection{Candidate Species}

Table 5.7 1ists the designated candidate species that are under consideration for possible addition to the threatened or endangered list.

\section{TABLE 5.7. Candidate Species}

\begin{tabular}{|c|c|c|c|}
\hline Common Name & Specif ic Name & $\underline{\text { Federal }}$ & $\underline{\text { State }}$ \\
\hline \multicolumn{4}{|l|}{ Moll uscs } \\
\hline Giant Col umbia River limpet & Fisherola nuttalli & & $\mathrm{X}$ \\
\hline Giant Columbia Spire Snai 1 & $\underline{\text { Lithoglvphus col umbi ana }}$ & & $\mathrm{x}$ \\
\hline \multicolumn{4}{|l|}{ Birds } \\
\hline Common Loon & Gavia immer & & $x$ \\
\hline Swai nsons Hawk & Buteo swainsoni & $X$ & \\
\hline Ferruginous Hawk & Buteo reqalis & $\mathrm{x}$ & \\
\hline Long-billed Curlew & Numenius americanus & $\mathrm{x}$ & \\
\hline
\end{tabular}

\subsection{WILDLFE REFUGES}

Several national and state wildlife refuges are located on or adjacent to the Hanford Site. These refuges are shown in Figure 5.7. 


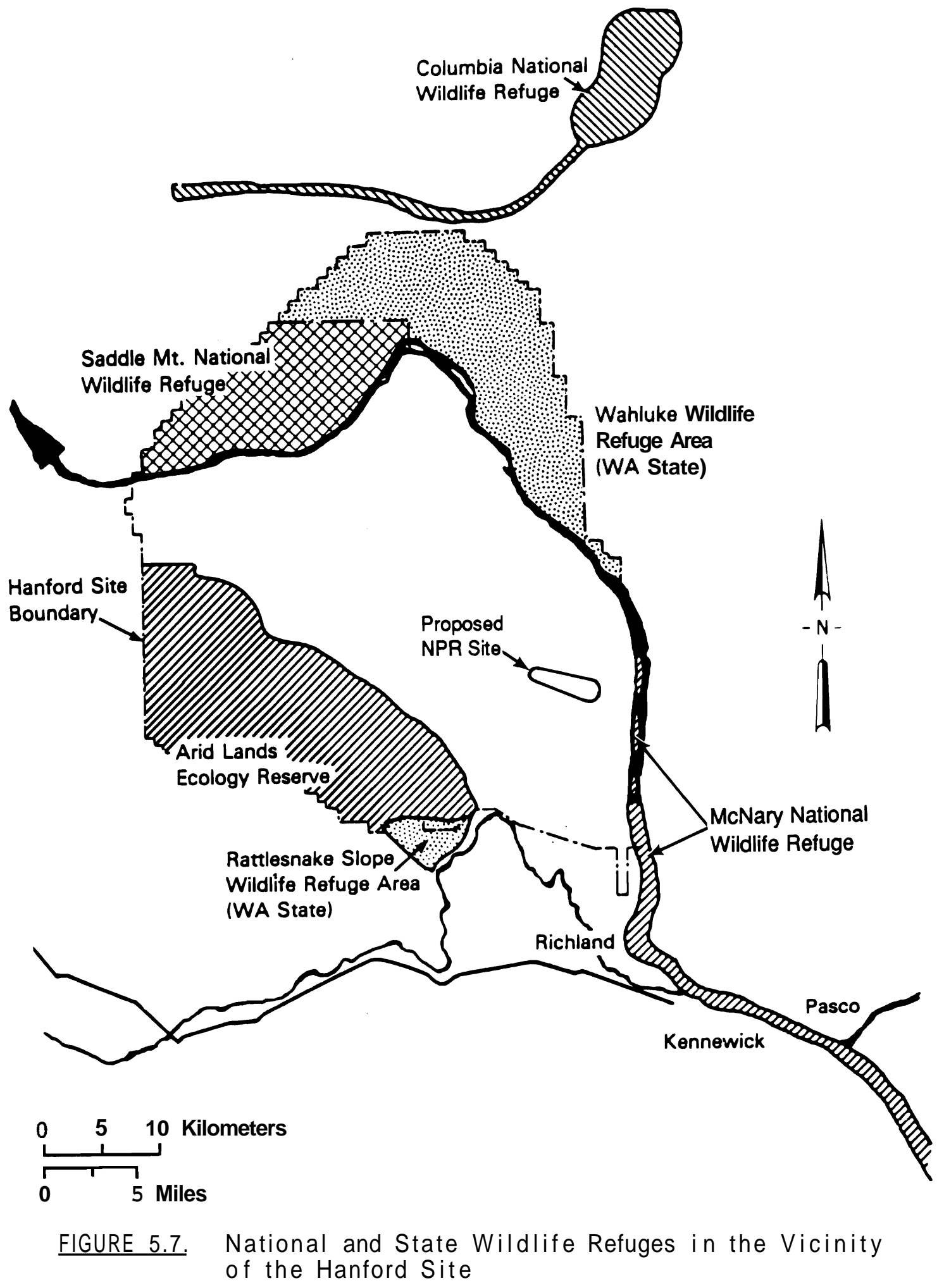





\subsection{HISTORICAL, ARCHAEOLOGICAL, AND CULTURAL RESOURCES}

\subsection{INTRODUCTORY OVERVIEW}

The Hanford Site is known to be rich in cultural resources. It contains numerous, wel1-preserved sites representing both the prehistoric and historic periods and is still thought of as a homeland by many Indian people. Rich paleontological deposits have been found in its bluffs and mountainsides. Despite the overall paleontological, archaeological, historical, and cultural wealth of the site, no historic properties or important cultural sites are located within or adjacent to the proposed NPR site.

\subsection{REGIONAL PREHISTORY, HISTORY, AND EIHNOGRAPHY}

The archaeological record of the mid-Columbia region begins over 11,000 years before present (B.P.) with Clovis hunters, whose distinctive spear points have been found scattered over the Pacific Northwest. Subsequently, beginning as early as 10,700 years B.P. and continuing to circa 8,500 years B.P., people lived as nomadic foragers (i.e., people who used food that was available, but did not store for the future), moving from place to place as foods became available in a complex, we11-planned seasonal round. As the environment became less markedly seasonal after 8,500 years B.P., people continued their mobile, foraging ways, but lost much of the seasonally prescribed aspect of their predecessors' adaptation. Their activities became confined largely to rivers and distant mountains, due to the aridity of the time. Sometime between 5,000 and 4,500 years B.P., the regional climate became markedly wetter, and some of the mobile foragers who lived around the fringes of the Columbia Basin became periodically sedentary. Others, in more arid central portions of the region, such as Hanford, appear to have continued the mobile ways of their ancestors. By 3,500 to 3,000 years B.P. people had adopted a collector strategy (i.e., subsistence based on food harvesting and storage). During productive seasons of the year they moved about their land harvesting and preserving provisions, which they then consumed while spending the winters in large semisubterranean houses (pithouses). This general adaptation continued, but by around 2,000 years B.P., pithouses had become aggregated into villages in a pattern resembling the Indian culture of 
the nineteenth century. Introduction of the horse in the mid-eighteenth century transformed the lives of many peoples surrounding the Hanford area, allowing them to travel to Montana for bison and throughout the Columbia Basin region to take advantage of the most productive landscapes. Regionalization of culture and enhanced trade were byproducts of this transportation revolution (Chatters 1989).

In late prehistoric and early historic times, the Hanford reach of the Columbia River was heavily populated by Indian people of various tribal affiliations. Wanapums dwelled along the Columbia River's west bank from south of Richland upstream to Vantage (Relander 1956; Spier 1936). Some of their descendants still live nearby and others have been incorporated into the Yakima and Umati11a Reservations. Palus people, whose descendants now dwell on the Nez Perce, Yakima, Umatilla, and Colville Reservations inhabited parts of the east bank (Relander 1956; Trafzer and Scheuerman 1986). These people retain traditional secular and religious ties to the region, and there are many, young and old alike, who have knowledge of the ceremonies and lifeways of their aboriginal culture. The Seven Drums religion, which had its start on the Hanford Site among the Wanapums, is still practiced by many members of all the reservations named above. Native plant and animal foods that can be found on the Hanford Site are part of the ceremonies performed by the Seven Drums practitioners.

The first Euro-Americans who came into this region were Lewis and Clark, who travelled along the Columbia and Snake Rivers during their 1803 to 1806 exploration of the Louisiana Territory (Chatters 1989). They were followed by fur trappers, who also passed through on their way to more productive lands up and down river and across the Columbia Basin. It was not until the 1860 s that merchants set up stores, a freight depot, and a ferry on the Hanford reach and Chinese miners began to work the gravel bars for gold. The White Bluffs Ferry was established at that time. Cattle ranches opened in the 1880s, and farmers soon followed. Several small, thriving towns grew up along the riverbanks in the early twentieth century, including Hanford, White Bluffs, and Ringold. Other ferries were established at Wahluke and Richmond. The towns and nearly all other structures were razed when the federal government acquired the land for the Hanford Nuclear Reservation in the early 1940s 
as part of the Manhattan Project. Nuclear reactors and chemical extraction plants were constructed for the production of plutonium to be used in World War II and to arm weapons during the Cold War. The first atomic explosion and the bomb that destroyed Nagasaki to end the war with Japan used plutonium from the Hanford B Reactor, which is listed as a National Mechanical Engineering Landmark and is being considered for nomination to the National Register.

The following listing sumnarizes the cultural chronology of the midColumbia region.

- $11,500-10,700$ B.P. - Highly mobile hunters of the Clovis Phase arrive in the Columbia Plateau region.

- $10,700-8,500$ B.P. - Small bands of highly mobile, nomadic foragers of the Windust Phase.

- 8.500-4.500 B.P. - Small bands of mobile Cascade Phase foragers confined by aridity to mountains and riverine areas of lowlands.

- 4500-3500 B.P. - Small foraging groups of the Early Frenchman Springs Phase, some sedentary, others mobile.

- 3500-2000 B.P. - Development of a semisedentary collector strategy Middle and Late Frenchman Springs Phases.

- 2000-220 B.P. - Semisedentary collectors aggregated into winter villages during the Cayuse/Harder Phase.

- 1730-1860s A.D. - Equestrian collectors; aggregation increased on seasonal basis. Euro-American traders and explorers enter the region.

- 1860s-1890s A.D. - Most native peoples are moved to reservations; mining and stockraising are pursuits of Euro-American and Chinese settlers.

- 1890s-1943 A.D. - Agricultural development and the founding of towns.

- 1943-Present - Establishment and operation of the Hanford Site for defense production and scientific research. 


\subsection{ARCHAEOLOGICAL SITES AND HISTORIC STRUCTURES}

Cultural Resource surveys that have been conducted in inland areas of the Hanford Site include a stratified random sample survey conducted for the Basalt Waste Isolation Project (Chatters 1989). That survey, although never completed, showed that, in areas greater than $400 \mathrm{~m}$ from the river, archaeological sites were only common on ridges and adjacent to perennial water sources. Densities of archaeological resources, which consisted of isolated artifacts and one small lithic scatter, ranged from $0-2 / \mathrm{km}^{2}$ on level, unwatered landforms (designated inland flats, stabilized dunes, and Cold Creek fine sediment landforms). The few finds that were made on these inland landforms were consistently located within $200 \mathrm{~m}$ of historic Indian trails that are identified on Government Land Office Maps drawn in the 1860s. Results of other, nonrandom survey and reconnaissance efforts conducted in inland areas (Rice 1981, 1984; Rice et al. 1978; ERTEC 1982; Morgan 1981; Smith et al. 1977) are consistent with these findings.

The areas that would be affected by the NPR Project have been more extensively surveyed for cultural resources than any other inland area of the Hanford Site. Fifteen surveys have been conducted in the proposed NPR site (Table 6.1), covering a total area of about $21.5 \mathrm{~km}^{2}$, or approximately $32 \%$ of the land surface. All undisturbed portions of the 200-East Area have been surveyed. Surveys varied in intensity from $100-\mathrm{m}$ to $20-\mathrm{m}$ intervals between pedestrian transects. Despite the extensive coverage, which includes al1 three possible sites for the NPR and the probable site of the target fabrication facility, no significant archaeological or historical properties have been found.

No prehistoric artifacts were found in the 200-East Area and only two isolated artifacts, both projectile points, have been reported at the proposed NPR site. Rice (1981) reported finding a lithic scatter in Section 33, the site of the proposed Skagit/Hanford nuclear plant, but reinspection of the materials collected revealed them to be fragments of a naturally decomposed block of opal.

Two historic archaeological sites are located near the proposed NPR site: $45 \mathrm{BN} 305 \mathrm{H}$ and $45 \mathrm{BN} 298 \mathrm{H}$ (ERTEC 1982). The 45BN305H site is the remains 
TABLE 6.1. Archaeological Surveys Conducted in the Proposed NPR Area of the Hanford Site

\begin{tabular}{|c|c|c|c|c|c|c|c|}
\hline $\begin{array}{l}\text { Map } \\
\text { Number }\end{array}$ & Project Name & Date of Survey & $\begin{array}{l}\text { Area Surveyed } \\
\text { Within Pro- } \\
\text { posed NR Site }\end{array}$ & Survey Techniques & $\begin{array}{l}\text { Cultural } \\
\text { Resources Within } \\
\text { Proposed NR Site }\end{array}$ & $\begin{array}{l}\text { Location of } \\
\text { Collection }\end{array}$ & References \\
\hline 3 & $\begin{array}{l}\text { Skagit/Hanford } \\
\text { Power }\end{array}$ & $11 / 16-12 / 11 / 81$ & 2.20 & $\begin{array}{l}\text { Pedestrian survey } \\
\text { Transect interval }=50 \mathrm{ft}\end{array}$ & None observed & None & GRIEC 1982 \\
\hline 8 & Hanford Recon. & $6 / 17-10 / 16 / 68$ & 6.73 & $\begin{array}{l}\text { Pedestrian survey } \\
\text { Transect interval not specified }\end{array}$ & None observed & Not specified & Rice 1968 \\
\hline 9 & WPPSS-WNP-2 & $8 / 19 / 72$ & & $\begin{array}{l}\text { Pedestrian survey } \\
\text { Transect interval not specified }\end{array}$ & None observed & None & Rice 1972 \\
\hline 12 & UNP-1 relocated & $5 / 3 / 74$ & & $\begin{array}{l}\text { Pedestrian survey } \\
\text { Transect interval not specified }\end{array}$ & None observed & Not specified & Rice 1974 \\
\hline 19 & $\begin{array}{l}\text { Wam water } \\
\text { irrigation }\end{array}$ & $5 / 30 / 78$ & 9.40 & $\begin{array}{l}\text { Pedestrian survey "Judgmental } \\
\text { sample" Transect interval }=100 \mathrm{~m}\end{array}$ & $\begin{array}{l}\text { No cultural resources } \\
\text { observed }\end{array}$ & None & Rice 1978, 1983 \\
\hline 20 & $\begin{array}{l}\text { Support } \\
\text { facilities }\end{array}$ & $10 / 80$ & & $\begin{array}{l}\text { Pedestrian survey "Judgmental } \\
\text { sample" Transect interval }=5 \mathrm{~m}\end{array}$ & $\begin{array}{l}\text { No cultural resources } \\
\text { observed }\end{array}$ & None & Rice 1980 \\
\hline 21 & Interior dunes & $6 / 81$ & 2.59 & $\begin{array}{l}\text { Pedestrian survey } \\
\text { Transect interval }=60 \mathrm{~m} \text { Shovel } \\
\text { test every } 30 \mathrm{~m} \text { to } 45 \mathrm{~cm}\end{array}$ & $\begin{array}{l}\text { One prehistoric } \\
\text { "site" (45BN266) }\end{array}$ & HCR & Rice 1981 \\
\hline 24 & $\begin{array}{l}\text { Potential } \\
\text { Reactors }\end{array}$ & $11 / 25,28 / 83$ & & $\begin{array}{l}\text { Pedestrian survey } \\
\text { Transect interval }=65 \mathrm{yd}\end{array}$ & & None & Rice 1984 \\
\hline 30 & FFIF & 2/16/78 & 0.12 & $\begin{array}{l}\text { Pedestrian survey } \\
\text { Transect interval unknown }\end{array}$ & $\begin{array}{l}\text { No cultural resources } \\
\text { observed }\end{array}$ & None & $\begin{array}{l}\text { Rice, Stratton } \\
\text { and Lindeman } \\
1978\end{array}$ \\
\hline 31 & Ashe substation & $6 / 12-21 / 76$ & 0.18 & $\begin{array}{l}\text { Pedestrian survey } \\
\text { Transect interval }=25 \text { to } 50 \mathrm{~m}\end{array}$ & $\begin{array}{l}\text { Late period project } \\
\text { point and ungulate } \\
\text { tooth (45BN229) }\end{array}$ & $\begin{array}{l}\text { Yes, Central } \\
\text { Uashington } \\
\text { State College }\end{array}$ & $\begin{array}{l}\text { Smith et al. } \\
197\end{array}$ \\
\hline 47 & HCRC\# 87-400-001 & $8 / 05 / 87$ & 0.01 & $\begin{array}{l}\text { Pedestrian survey } \\
\text { Transect interval }=\mathbf{2 0} \mathrm{m}\end{array}$ & $\begin{array}{l}\text { No cultural resources } \\
\text { observed }\end{array}$ & None & $\begin{array}{l}\text { Cadoret and } \\
\text { Chatters } 1988\end{array}$ \\
\hline 48 & HCRC\# 87-400-002 & $10 / 16 / 87$ & 0.02 & $\begin{array}{l}\text { Pedestrian survey } \\
\text { Transect interval }=20 \mathrm{~m}\end{array}$ & $\begin{array}{l}\text { Basal-notched project } \\
\text { point }(200-1200 \mathrm{AD})\end{array}$ & $\begin{array}{l}\text { Collected, } \\
\text { HCR } \\
\text { (HI -87-018) }\end{array}$ & Letter report \\
\hline 49 & HCRC\# 87-400-007 & $4 / 6,13 / 88$ & 0.12 & $\begin{array}{l}\text { Pedestrian survey } \\
\text { Transect interval }=20 \mathrm{~m}\end{array}$ & $\begin{array}{l}\text { No cultural resources } \\
\text { observed }\end{array}$ & None & $\begin{array}{l}\text { Letter report } \\
\text { in preparation }\end{array}$ \\
\hline 63 & HCRC\# 88-600-002 & $4 / 13 / 88$ & 0.02 & $\begin{array}{l}\text { Pedestrian survey } \\
\text { Transect interval }=20 \mathrm{~m}\end{array}$ & $\begin{array}{l}\text { No cultural resources } \\
\text { observed }\end{array}$ & None & Letter report \\
\hline 74 & $\begin{array}{l}\text { BHIP Borehole pads } \\
\text { DC-7 and DC-8 }\end{array}$ & $3 / 24 / 88$ & $<0.01$ & $\begin{array}{l}\text { Pedestrian survey } \\
\text { Transect interval }=20 \mathrm{~m}\end{array}$ & $\begin{array}{l}\text { No cultural resources } \\
\text { observed }\end{array}$ & None & $\begin{array}{l}\text { BWIP Environ- } \\
\text { mental Review }\end{array}$ \\
\hline
\end{tabular}


of a sheepherder's cabin and corral; the other site is a scatter of cans and other trash. Neither is considered to be significant. The White Bluffs Road, an Indian trail later converted to a freight road, passes through the 200-West Area, well to the west of the proposed NPR project area.

Properties associated with more recent historic events are located in the 200-East Area. Five buildings (271-B, 224-B, 272-EA, and 284-E) were constructed during World War II as part of the Manhattan Project. The 271-B building, or B-Plant was used for plutonium separation; the other structures were support facilities (shop, store houses, and powerhouse, respectively). One other building was constructed during early years of the Cold War. The 2101-M support laboratory was built in 1953. These properties are scheduled for evaluation pursuant to the National Historic Preservation Act during FY 1990.

Based on these findings, and the added fact that no Indian trails cross the proposed construction sites, it can be concluded that no significant archaeological or historical properties are known in the immediate project area.

\subsection{NATIVE AMERICAN CULTURAL RESOURCES}

Indian people hold the land sacred, so in their terms the entire Hanford Site is culturally important. However, within that larger area there are places with greater importance that have been identified by Indian elders in the early 1950s (Relander 1956), and during interviews conducted in 1988 for preparation of the Hanford Cultural Resources Management Plan (Chatters 1989). Certain landmarks, especially Rattlesnake Mountain, Gable Mountain, Gable Butte, Goose Egg Hill, Coyote Rapids, and the White Bluffs segment of the Columbia River have special significance (Figure 6.1). The hills and mountains are places that figure in the mythology of creation and have long been used as sites for the spirit quest. It is by this ceremony that Indian youths meet the supernatural guides that help them through life. Coyote Rapids was the site of the first Seven Drums ceremony in the nineteenth century and was also an important fishing place. The White Bluffs reach of the Columbia River was an important winter camp location and offered the best 


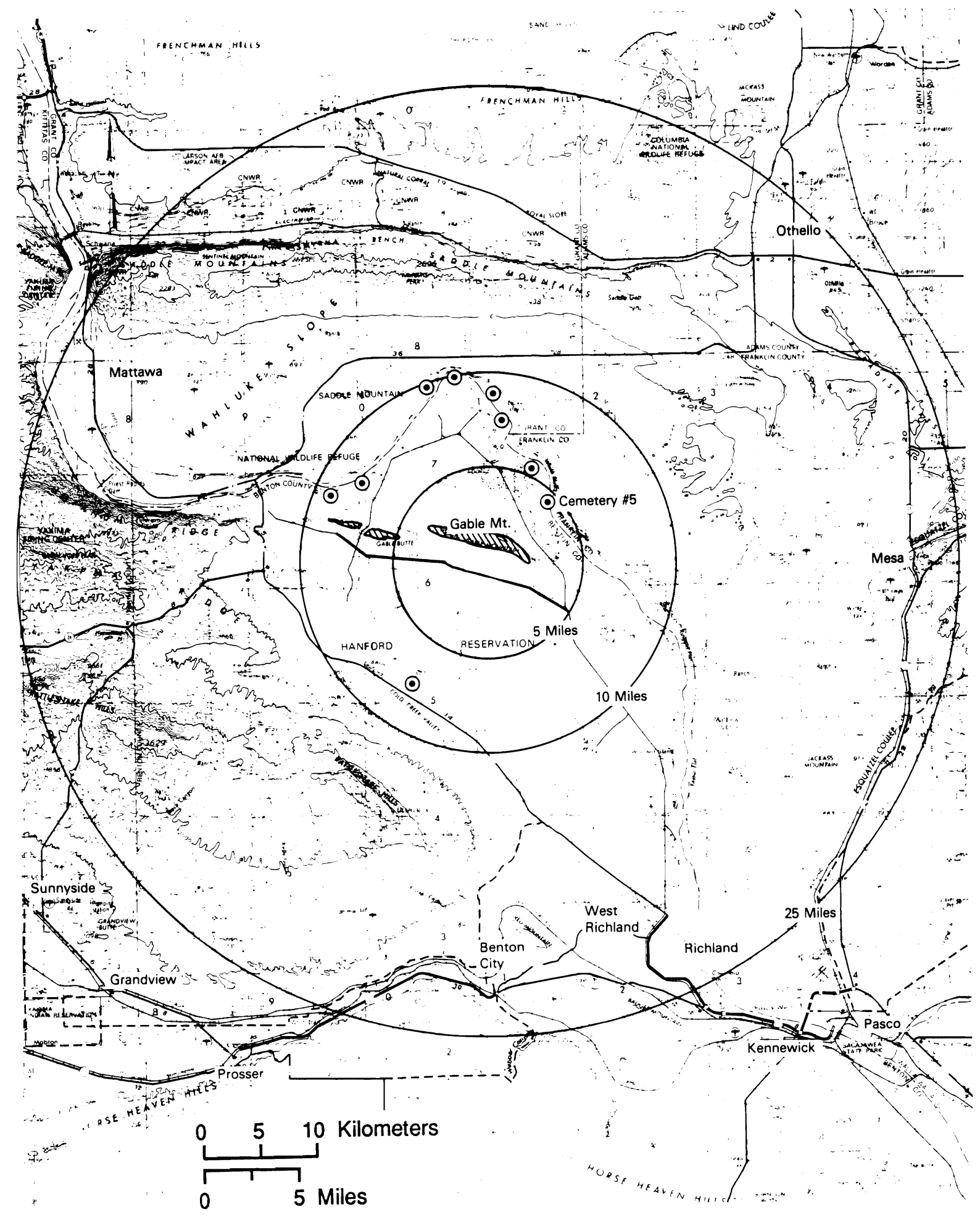

FIGURE 6.1. Areas on the Hanford Site that are Considered Significant by Indian People 
salmon fishing. The many cemeteries that are found along the Columbia River are also considered to be sacred; many Indian people hold sacred all archaeological sites left by their ancestors.

Traditional foods and medicinal plants that may be found on the Hanford Site are also important to Indian groups. Foremost among these is the salmon, which spawns in great numbers especially in the White Bluffs area.

The proposed NPR site is not in direct contact with any of the areas identified as especially important. However, it is within sight of Rattlesnake Mountain and, to a lesser degree Gable Mountain. Goose Egg Hill, which is especially important to members of the Wanapum Band, is about $9 \mathrm{~km}$ from the western apex of the triangular area that includes the proposed NPR site.

\subsection{PALEONTOLOGICAL RESOURCES}

Paleontological remains of Pliocene and late Pleistocene age have been found on the Hanford Site. The Upper Ringold Formation, of late Pliocene age, consists of fluvial deposits containing the remains of fish, reptiles, amphibians and a variety of mammals (Gustafson 1978). Mammoth bones frequently are found in the Tuchet beds, slack-water fluvial sediments of the late Pleistocene age that were deposited along the slopes of ridges surrounding the Hanford Site (Chatters 1989). Pasco Gravels, which underlie all areas being considered for NPR construction, are of late Pleistocene age, but lack paleontological remains. 


\subsection{SOCOBCONOMICS}

Activity on the Hanford Site plays a dominant role in the socioeconomics of the Tri-Cities and other parts of Benton and Franklin counties. The agricultural community also has a significant effect on the local economy. The economic influences of Hanford are significant, but Hanford impacts the social aspects of the community as well through its dependence on a technically oriented workforce. Any major changes in Hanford activity would potentially most affect the Tri-Cities and other areas of Benton and Franklin counties. Detailed analyses of the socioeconomics are found in Scott et al. (1987), Scott et al. (1989), and Watson et al. (1984).

\subsection{EMPLOYMENT AND NCOME}

Three major sectors have been the principal driving forces of the econamy in the Tri-Cities since the early 1970s: 1) the DOE and its contractors operating the Hanford Site, 2) WHPS in its construction and operation of nuclear power plants, and 3) the agricultural community, including a substantial food processing component. With the exception of a minor amount of agricultural commodities sold to local area consumers, the goods and services produced by these sectors are exported from the Tri-Cities. In addition to the direct employment and payrolls, these major sectors also support a sizeable number of jobs in the local economy through their procurement of equipment, supplies, and business services.

In addition to these three major employment sectors, three other components can be readily identified as contributors to the economic base of the Tri-Cities economy. The first of these, loosely termed "other major employers" includes five such employers: 1) Advanced Nuclear Fuels in North Richland, 2) Sandvik Special Metals in Kennewick, 3) Boise-Cascade in Wallula, 4) Burlington Northern Railroad, and 5) Iowa Beef Processors. The second of the other components is tourism. The Tri-Cities area has increased its convention and recreational travel business substantially in recent years. The final component in the economic base relates to the local purchasing power 
generated from retired former employees. Government transfer payments in the form of pension benefits constitute a significant proportion of total spendable income in the local economy.

\subsubsection{DOE Contractors (Hanford)}

Hanford continues to dominate the local employment picture with nearly one-fifth of the total jobs in Benton and Franklin counties in 1988 $(11,300$ out of 61,500). Beyond Hanford's direct employment, Hanford's payroll impacts the Tri-Cities and state economy. These effects are further described in Section 7.2.

From October 1987 through September 1988, D0E and its contractors purchased approximately $\$ 96$ million of goods and services in Washington State. The most recent study shows that total DOE procurement is estimated to have supported approximately 800 jobs in Benton and Franklin counties, the vast majority of these jobs falling into the wholesale and retail sector (Scott e t a 1. 1987).

\subsubsection{Washinqton Public Power Supply System}

Although activity related to nuclear power construction ceased with the completion of the WNP-2 reactor in 1983, WPPSS continues to be a major employer in the Tri-Cities area. Headquarters personnel based in Richland oversee the operation of one generating facility and perform a variety of functions related to two mothballed nuclear plants and one standby generating facility. In 1988, WPPSS headquarters employment was near 1,600 workers. Washington Public Power Supply System activities generated roughly a $\$ 59$ million payroll in the Tri-Cities during the year.

\subsubsection{Aqriculture}

Agricultural activities in Benton and Franklin counties are responsible for nearly 10,000 jobs, or nearly one-sixth of total employment. According to the U.S. Department of Commerce's Regional Economic Information System, there were about 2,300 people classified as farm proprietors in 1986. Farm proprietors' income from this same source was estimated to be $\$ 67.9$ million 
in the same year. In 1988, farm income likely exceeded $\$ 70$ million due to increased value of production for major crops in the bicounty area (Scott et al. 1989).

Crop and livestock production in the bicounty area generated about 4,600 wage and salary jobs, as represented by the employees covered by unemployment insurance. The presence of seasonal farm workers would make the total number of farm workers higher. Apart from the difficulty of obtaining reliable information on the number of seasonal workers, there is the question of how much of these earnings are actually spent in the local area. For this analysis, we assumed that the impact of seasonal workers on the local economy is sufficiently small to be safely ignored.

The area's farms and ranches generate a sizeable number of jobs in supporting activities, such as agricultural services (e.g., application of pesticides and fertilizers, irrigation system development, etc.) and sales of farm supplies and equipment. These activities, often called "agri-business," employ about 1,200 people. This figure has been reduced from the estimate of 1,350 jobs made in 1981 by the Washington State Employment Security Department based on a somewhat depressed farm sector in 1986, as compared to 1981. For lack of better information, this 1,200 figure was held constant for 1988 estimate.

Although formally classified as a manufacturing activity, food processing is a natural extension of the farm sector discussed above. More than 20 food processors in Benton and Franklin counties produce such things as potato products, canned fruits and vegetables, wine, and animal feed. Seasonally adjusted full-time employment in this sector averaged about 2,650 in 1987 (Scott et al. 1989).

\subsubsection{Other Major Emplovers}

Other major empl oyers--Advanced Nuclear Fuels, Sandvi k Special Metals, Iowa Beef Processors, Boise Cascade, Burlington Northern Railroad--employ over 3,800 people in Benton and Franklin counties. Although Boise Cascade's Wallula mill lies outside both Benton and Franklin counties, the vast majority of its workforce resides in the Tri-Cities. 


\subsubsection{Tourism}

In recent years, tourism has increased significantly in the Tri-Cities. In 1987, nearly 700 conventions or tournaments were held in the Tri-Cities. These activities drew 56,500 visitors who spent an estimated $\$ 17.8$ million. A study by the Washington State Department of Tourism estimated that overall tourism expenditures in the Tri-Cities were roughly $\$ 80$ million in 1986 . An adjustment to these figures was made to deduct the business travel associated with visitors on DOE business. This activity generated an estimated $\$ 15 \mathrm{mil}$ Iion payroll and roughly 1,900 jobs in the local economy.

In the first half of 1988, 395 groups came to the Tri-Cities with 39,000 visitors and an estimated $\$ 12.1$ million of expenditures. This compares with $\$ 6.3$ million of expenditures in the first half of 1987.

\subsection{6 $\quad$ Retirees}

Although the Benton and Franklin counties have a relatively young popuIation (58\% under the age of 35 as compared with a national average of $56 \%$ ), over 10,000 people over the age of 65 reside in Benton and Franklin counties. In fact, the portion of the total population that is 65 years and older is currently increasing at a greater rate than is being experienced by Washington State. This segment of the population supports the local economy on the basis of income received from government transfer payments and pensions, private pension benefits, and prior individual savings.

Although information on private pensions and savings is not available, data are available regarding the magnitude of government transfer payments. The Department of Commerce's Regional Economic Information System has estimated transfer payments by various programs at the county level. A summary of estimated major government pension benefits received by the residents of Benton and Franklin counties in 1986 is shown in Table 7.1. Table 7.1 does not show pension benefits from private contractors. The total transfer payment income was about $\$ 147$ million in 1988, which is calculated by extrapolating 1986 figures by the change in the Consumer Price Index between 1986 and 1988. About two-thirds of the Social Security payments go to retired workers; the remainder are for disability and other payments. The historical 
TABLE 7.1. Government Retirement Payments in Benton and Franklin Counties, 1986 (millions of dollars)

\begin{tabular}{|c|c|c|c|}
\hline & $\begin{array}{l}\text { Benton } \\
\text { County }\end{array}$ & $\begin{array}{l}\text { Franklin } \\
\text { Countv } \\
\end{array}$ & $\underline{\text { Total }}$ \\
\hline $\begin{array}{l}\text { Social Security (including survivors } \\
\text { and disability) }\end{array}$ & 70.4 & 23.9 & 94.3 \\
\hline Railroad retirement & 1.8 & 2.8 & 4.6 \\
\hline Federal civilian retirement & 7.7 & 2.2 & 9.9 \\
\hline $\begin{array}{l}\text { Veterans pension and military } \\
\text { retirement }\end{array}$ & 11.7 & 3.3 & 15.0 \\
\hline \multirow[t]{2}{*}{ State and local employee retirement } & 16.7 & 4.1 & 20.8 \\
\hline & $\$ 108.3$ & $\$ 36.3$ & $\$ 144.6$ \\
\hline
\end{tabular}

importance of government activity in the Tri-Cities area is reflected in the relative magnitude of the government employee pension benefits as compared to total payments.

The Washington State Office of Financial Management estimated that there were 10,865 people 65 years or older living in Benton and Franklin counties in 1988. This estimate implies per capita transfer payments of $\$ 13,500$. Of course, some of these payments are received by younger retirees. Adding in the population aged 60 to 64 , this average is reduced to about $\$ 9,300$, which may be a reasonable lower bound. Data for 1980 show that monthly social security benefits in Benton County were about $9 \%$ higher than the national average. In addition, the greater share of retirees receiving government employee pensions, as mentioned above, is also likely contributing to the higher per capita figure.

The discussion above may help to reveal that the purchasing power of senior citizens is an important component of the Tri-Cities economy just as for the entire nation. Taken as a whole, the estimated income of this component of the basic sector is roughly equivalent to the entire agricultural sector. 


\subsubsection{Secondarv Sector}

The secondary sector consists of all other workers in Benton and FrankI in counties. Wholesale and retail trade dominated the secondary sector with about 11,000 wage and salary workers. (a) Various services (excluding business services, mainly DOE contractor employment) employ about 6,000 people and local government employs around 8,000 workers. The remaining workers in the secondary sector are in transportation, communication, utilities, finance, real estate, and construction.

\subsection{HANFORD AND THE LOCAL AND STATE EOONOMY}

In 1988, Hanford employment accounted directly for $21 \%$ of total nonagricultural employment in Benton and Franklin Counties and $0.6 \%$ of a 11 nonagricultural state-wide jobs. Hanford employs more Washingtonians than the entire primary aluminum industry and almost as many as the pulp and paper industry.

Hanford accounts for over two-thirds of Washington employment in chemicals and allied products, or about $3 \%$ of all Washington manufacturing jobs. Hanford Site operations directly account for an estimated $33 \%$ of the dollars earned in Benton and Franklin Counties in 1988 and $0.8 \%$ of all dollars earned in Washington State industries.

Previous studies reveal that each Hanford job supports about 1.2 additional jobs in the local service sector of Benton and Franklin Counties (about 2.2 total jobs) and about 1.5 additional jobs in the state's service sector (about 2.5 total jobs; Scott et al. 1987). Similarly, each dollar of Hanford income supports about 2.1 dollars of total local incomes and about 2.4 dollars of total statewide incomes. Based on these multipliers in Benton and Franklin Counties, Hanford directly or indirectly accounts for over $40 \%$ of all jobs.

(a) To some degree, wholesale and retail trade also contains a "basic" component, since the Tri-Cities serve as a regional trade center for an area reaching northward into Grant County and southward to Oregon. The extent of this basic activity is not known, but it results in an overstatement of the size of the secondary sector relative to the basic sector. 
Based on November 1, 1986 postal records, 92\% of the direct employment and payroll of Hanford go to residents of the Benton and Franklin Counties. Nearly $80 \%$ of the employment and payroll go to residents who reside in one of the Tri-Cities. Over 45\% of the payroll and employment go to Richland residents, $27.7 \%$ to Kennewick residents, and $9.5 \%$ to Pasco residents. West Richland, Benton City, Prosser, and other areas in Benton and Franklin Counties account for $11.5 \%$ of total employment and payroll.

Hanford and contractors spent nearly $\$ 154$ million, or $47.5 \%$ of total procurements of \$324 mi17ion, initially through Washington firms in 1986. About $18 \%$ of Hanford orders were filled by Tri-Cities firms. In many cases, these procurements filled by Tri-Cities firms only result in retail and wholesale markups; however, a significant portion of a 17 Hanford orders, \$6.6 million, are placed directly to Washington manufacturers.

Contractors spent $\$ 22$ million on electricity and other utilities in 1986, ordered nearly $\$ 19$ million in business services, and spent $\$ 73$ million on Washington retail and wholesalers. Finally, DOE and its contractors provided about $\$ 16$ million (mainly in grants) to local governments and others for a variety of public purposes.

Hanford contractors paid a total of $\$ 10.9$ million in FY 1988 in state taxes on operations and purchases. Estimates show that Hanford employees paid \$27.0 mill ion in state sales, use, and other taxes and fees in FY 1988. In addition, Hanford paid $\$ 0.9$ million to local government in Benton, Frank1in, and Yakima Counties in local taxes and fees (Scott et al. 1989).

\subsection{DEMOGRAPHY}

Estimates by Washington State's Office of Financial Management, dated April 1988, place the Benton and Franklin Counties' population totals at 104,100 and 35,500, respectively. These estimates compare with similar 1980 census data in which Benton County had 109,376 residents and Franklin County's population totaled 34,961. The year 1982 represents the period with the highest population: an estimated 111,700 residents in Benton County and 36,200 residents in Frank1in County. 
Within each county, the 1988 estimates distribute the Tri-Cities population as follows: Richland, 30,140; Kennewick, 37,180; and Pasco, 18,430. The populations of Benton City, Prosser, and West Rich7and totaled 9,460 in 1988. The unincorporated population of Benton County was 27,320. In Franklin County, incorporated areas other than Pasco have a total population of 2,570. The unincorporated population of Franklin County is 14,500 .

The population estimates of Benton and Franklin Counties show several factors that distinguish the population from Washington State's population. The population of Benton and Franklin Counties is young with 58\% of the total population under the age of 35 compared to $53 \%$ of the total state population. The largest age group in Benton and Franklin Counties is the group that is less than 4 years old. This group represents almost $10 \%$ of the total population.

\subsection{HOUSING}

In 1988, nearly $88 \%$ of all housing (of 38,337 total units) in the Tri-Cities was occupied. Single-unit housing, which represents nearly $57 \%$ of the total units, has an average 93\% occupancy rate throughout the Tri-Cities. Multiple-unit housing, defined as housing with two or more units, has an occupancy rate of nearly $81 \%$. Pasco has the lowest occupancy rate in all categories of housing: single/unit, $93 \%$; multiple/unit, 78\%; and mobile homes and trailers, 84\%. The mobile-home occupancy rate, however, is the only rate that is significantly lower than that of the other cities.

Table 7.2 shows a detailed listing of total units and occupancy rate by type in the Tri-Cities.

\subsection{TRANSPORTATION}

The Tri-Cities serves as a regional transportation and distribution center with major air, land, and river connections. The Tri-Cities has direct rail service, provided by Burlington Northern and Union Pacific, connecting the area to more than 35 states. The Washington Central Railroad serves eastern Washington also. Union Pacific operates the largest fleet of refrigerated rail cars in the United States and is essential to food processors 
TABLE 7.2. Total Units and Occupancy Rates (April 1988 Estimates)

\begin{tabular}{|c|c|c|c|c|c|c|c|c|}
\hline & \multicolumn{2}{|c|}{ All Units } & \multicolumn{2}{|c|}{ Sinqle Units } & \multicolumn{2}{|c|}{ Multiple Units } & \multicolumn{2}{|c|}{$\begin{array}{c}\text { Mobile Homes/ } \\
\text { Trailers }\end{array}$} \\
\hline & Total & $\begin{array}{l}\text { Rate, } \\
\%\end{array}$ & Total & $\begin{array}{l}\text { Rate, } \\
\%\end{array}$ & Total & $\begin{array}{l}\text { Rate, } \\
\%\end{array}$ & Total & $\begin{array}{c}\text { Rate, } \\
\% \\
\end{array}$ \\
\hline Richland & 13,858 & 89 & 8,737 & 95 & 4,665 & 78 & 456 & 95 \\
\hline Pasco & 8,052 & 86 & 3,990 & 93 & 3,069 & 78 & 1,993 & 84 \\
\hline Kennewick & 16,427 & 90 & 9,130 & 92 & 5,867 & 84 & 1,430 & 90 \\
\hline $\begin{array}{l}\text { Tri-Cities } \\
\text { Average }\end{array}$ & 38,337 & 89 & 21,857 & 93 & 13,601 & 81 & 2,879 & 91 \\
\hline
\end{tabular}

Source: State of Washington (1988).

that ship frozen food from this area. Passenger rail service is provided by Amtrak, which has a station in Pasco.

Docking facilities at the Ports of Benton, Kennewick, and Pasco are important aspects of this region's infrastructure. These facilities are located on the 525-km-long commercial waterway, made up of the Snake River and the Columbia River, extending from the Ports of Lewiston-Clarkston in Idaho to the deep-water ports of Portland, Oregon, and Vancouver, Washington. The average shipping time from the Tri-Cities to these deep water ports by barge is 36 hours (Evergreen Community Development Association 1986).

Daily air passenger and freight services connect the area with most major cities through the Tri-Cities Airport, located in Pasco. The airport is currently served by two commuter-regional and two national airlines. The main runway is $2,350 \mathrm{~m}$ in length and can accommodate landings and takeoffs by medium-range commercial aircraft, such as the Boeing 727-200 and Douglas DC-9. The Tri-Cities airport currently handles about 145,000 passengers per year. Projections indicate that the recently expanded terminal can serve almost 250,000 passengers annually. Two additional airports, located in Richland and Kennewick, are limited to serving small aircraft.

The Tri-Cities are linked to the region by five major highways. Route 395 joins the area with Spokane to the northeast. Interstate 182 connects Interstate 82 with Route 395 north of Pasco. Both Route 395 and 
Route 240, which crosses through the Hanford Site, connect with Interstate 90 to the north. Route 12 links the region with Yakima to the northwest;

Lewiston, Idaho to the east; Walla Walla to the southeast. Finally, the area is linked to Interstate 84 to the south, via Interstate 82 and Route 14. Routes 240 and 24 traverse the Hanford Site and are maintained by Washington State. Other roads within the reservation are maintained by the DOE.

\subsection{EDUCATIONAL SERVICES}

\subsubsection{Primary and Secondarv}

Primary and secondary education are served by the Richland, Kennewick, Pasco, and Kiona-Benton school districts. The combined 1989 spring enrollment for all districts was approximately 25,000 students. This total consists of approximately 10,000 students from the Kennewick school district, and about 6,700 and 6,200 students, respectively, in the Richland and Pasco school districts. In 1987, the Kennewick and Pasco school districts were operating near or at their capacity. This is not the case with the Richland District, where enrollment peaked at 8,700 in the early 1980s. By opening schools that closed in the 1ast several years, the Richland School District could expand enrollment by about 30\%. In 1987, Kiona-Benton and Burbank school districts were operating at about two-thirds capacity.

\subsubsection{Post-Secondarv}

Post-secondary education in the Tri-Cities area is provided by a junior college, Columbia Basin College, and by the Tri-Cities University Center (TUC). Washington State University is currently in the process of creating a branch campus in the Tri-Cities. The TUC offers a variety of upper-division, undergraduate, and graduate degree programs. In 1988, enrollment at these two institutions was approximately 7,000 students, with a capacity for about 10,000 students. Many of the programs offered by these two institutions are geared toward the vocational and technical needs of the area. Currently 8 undergraduate and 14 graduate programs are available. 


\subsection{HEALTH CARE AND HUMAN SERVICES}

The Tri-Cities have three major hospitals and four minor emergency tenters. All three hospitals offer general medical services and include a 24-hour emergency room, basic surgical services, intensive care, and neonatal care.

Kadlec Medical Center, located in Richland, has 136 beds and runs at 50\% capacity. The 6,200 annual admissions represent over 45\% of the Tri-Cities market, and 65\%, or 4,000, of these admissions are non-Medicare/Medicaid patients who average 3.1 days per admission.

Kennewick General Hospital (KGH) maintains a 50\% occupancy rate of its 71 beds with its annual 3,000 admissions. Approximately 75\% of KGH's admissions are from Kennewick, and 5\% are from Richland. Non-Medicare/Medicaid patients average 3.2 days per admission and represent $48 \%$ of total admissions.

Our Lady of Lourdes Hospital, located in Pasco, has an occupancy rate of 27\%; however, the hospital performs a significant amount of out-patient care, which serves as the primary source of income for the hospital. In 1986, Our Lady of Lourdes had 3,000 admissions of which 50\% were non-Medicare/Medicaid. patients. Each non-Medicare/Medicaid admission stayed an average of 3.2 days.

The Tri-Cities offer a broad range of social services. State human service offices in the Tri-Cities include the Job Services office of the Employment Security Department; Food Stamp offices; the Division of Developmental Disabilities; Financial and Medical Assistance; the Child Protective Service; emergency medical service; a senior companion program; and vocational rehabilitation.

The Tri-Cities are also served by a large number of private agencies and vol untary human services organizations. The United Way, an umbrell a fundraising organization, proposed contributions of $\$ 1.6$ million in 1989 to its member agencies throughout the area. These member agencies had a cumulative budget total of $\$ 13.7$ million in 1986 (United Way 1986). Some of the member agencies include: Association for Retarded Citizens, Tri-Cities Chaplaincy, 
Developmental Center, Food Bank, Lutheran Social Services, Mental Health Center, Rape Relief, American Red Cross, Salvation Army, and A Woman's Place. A short listing of examples of human services facilities and organizations in the Tri-Cities follows on Table 7.3.

\subsection{POLCE AND FIRE PROIBCTION}

Police protection in Benton and Franklin counties is provided by Benton and Franklin Counties' sheriff departments, local municipal police departments, local municipal fire departments, and the Washington State Patrol Division headquartered in Kennewick.

Table 7.4 shows the number of commissioned officers and patrol cars in each department. The Kennewick, Richland, and Pasco municipal departments maintain the largest staffs of commissioned officers with 48, 40, and 38 , respectively. Table 7.5 indicates the number of fire-fighting personnel, both paid and volunteer, on the staffs of fire districts in the area.

By comparing violent crimes (homicide, rape, robbery, and aggravated assault) and property crimes (burglary, larceny/theft, motor vehicle theft, and arson) to the population for 1987, differences are revealed in the crime rate between Benton and Franklin counties and each city, as measured by crimes per 1,000 residents. In Benton County, violent crimes occur at a rate of 2.6 per year per 1,000 residents and property crimes at 59.4 per year per 1,000 residents. Table 7.6 illustrates that both violent and property crimes in Richland occur at a lesser rate than in Kennewick. Violent crime and property crime rates for Pasco are the highest of the Tri-Cities at 10.2 per 1,000 residents and 129.9 per 1,000 residents, respectively.

The Benton County violent crime rate per 1,000 residents is slightly below those of Washington State, while Franklin County's rate exceeds the Washington State rates.

\subsection{PARKS AND RECREATION}

The convergence of the Columbia, Snake, and Yakima rivers offers the residents of the Tri-Cities a variety of recreational opportunities. 
TABLE 7.3. Examples of Human Services Facilities and Organizations in the Tri-Cities

Facility or Orsanization

Benton-Frank1 in Association for Retarded Citizens

Benton-Frankl in Developmental Center

\section{Catholic Family Services \\ Lutheran Social Services of Washington \\ Children's Home Society of Washington}

Col umbi a Industries

Benton-Frank1 in Counci 1 on Aging

\section{Evergreen Legal Services}

Good Shepherd Home

A Woman's Pl ace

Planned Parenthood of BentonFranklin Counties

Tri-Cities Chaplaincy

Tri-Cities Food Bank

\section{Descriptive Comments}

Provides counseling, recreation, transportation and referral services for learningdi sabled individuals

Provides services and programs for developmentally disadvantaged children.

Provides foster care programs, family and individual counseling programs and adoptive services.

Provides residential treatment facilities and program for emotionally disturbed children.

Assists the physically and mentally disabled toward meaningful employment through vocational evaluation, work training, job placement and sheltered employment.

Provides meals, household assistance, health care, information and transportation services.

Provides free legal aid program for civil cases involving low-income persons.

Provides a residential treatment program for adolescent girls with behavioral problems.

Provides crisis phone counseling and temporary residence for women and their children who are victims of domestic violence.

Provides family planning education, information and assistance programs.

Provides chaplaincy service to those with life-threatening illnesses and their families, including a hospice program.

Provides food for those in need.

Source: Watson et a1. (1984). 
TABLE 7.4. Police Personnel in Tri-Cities, 1988

Benton City Municipal

Kennewick Municipal

Pasco Municipal

Richland Municipal

West Richland Municipal

County Sheriff, Benton County

County Sheriff, Franklin County

\section{Commissioned Officers Patrol Cars}

Source: Each department office, August 1988.

TABLE 7.5. Fire Protection in Tri-Cities, 1988

\begin{tabular}{|c|c|c|c|c|}
\hline & Fire Fighting Personnel & $\underline{\text { Volunteers }}$ & $\underline{\text { Total }}$ & Service Area \\
\hline Kennewick & 39 & 0 & 39 & City of Kennewick \\
\hline Pasco & 21 & 0 & 21 & City of Pasco \\
\hline Richland & 38 & 0 & 38 & City of Richland \\
\hline BCRFD 1 & 5 & 100 & 105 & Kennewick Area \\
\hline BCRFD 2 & 0 & 21 & 21 & Benton City \\
\hline BCRFD 4 & 2 & 28 & 30 & West Richland \\
\hline
\end{tabular}

Source: Each department office, August 1988.

TABLE 7.6. Violent and Property Crimes, 1988

\begin{tabular}{lccc} 
& $\begin{array}{r}\text { Violent Crimes } \\
\text { per } 1,000\end{array}$ & \multicolumn{1}{c}{$\begin{array}{c}\text { Property Crimes } \\
\text { per } 1,000 \text { Residents }\end{array}$} \\
\cline { 2 - 2 } Benton County & 2.6 & 59.4 \\
$\quad$ Richland & 1.2 & 49.1 \\
Kennewick & 2.5 & 93.3 \\
$\quad$ Franklin County & 6.1 & 81.6 \\
$\quad$ Pasco & 10.2 & 129.9 \\
Yakima County & 4.7 & 81.6 \\
Spokane County & 3.6 & 64.4 \\
Washington State & 4.5 & 67.0
\end{tabular}


The Lower Snake River Project includes Ice Harbor, Lower Monumental, Little Goose, Lower Granite locks and dams, and a levee system and parkway at Carkston and Lewiston. While navigation capabilities and the electrical output represent the major benefits of this project, recreational benefits have also resulted. The Lower Snake River Project provides boating, camping, and picnicking facilities in nearly a dozen different areas along the Snake River. In 1986, nearly 385,000 people visited the area and participated in activities along the river.

Simil arly, the Columbia River provides ample water recreational opportunities on the lakes formed by the dams. Lake Wallula, formed by McNary Dam, offers a large variety of parks and activities, which attracted over 3 million visitors in 1986. The Columbia River Basin is also a popular area for migratory waterfowl and upland game bird hunting.

Other opportunities for recreational activities in the Tri-Cities are accommodated by the indoor and outdoor facilities avail able, as described in Table 7.7. Numerous tennis courts, ball fields, and golf courses offer outdoor recreation to residents and tourists. Several privately owned health clubs in the area offer indoor tennis and racquetball courts, pools, and exercise programs. Bowling lanes and roller skating rinks also serve each of the Tri-Cities.

\subsection{UTILITIES}

\subsubsection{Water}

The principal source of water in the Tri-Cities and the Hanford Site is the Columbia River from which the water systems of Richland, Pasco, and Kennewick draw a large portion of the average 1 million $\mathrm{m}^{3}$ necessary each day. Each city operates its own supply and treatment system.

The Richland water supply system derives about $90 \%$ of its water from the Col umbia River and the remaining $10 \%$ from groundwater we $11 \mathrm{~s}$. Richland's total usage in 1988 was 16.8 million $\mathrm{m}^{3}$ (residential, 9.8 million $\mathrm{m}^{3}$; industrial and commercial, 5.3 mil Tion $\mathrm{m}^{3}$; parks, 1.0 mill ion $\mathrm{m}^{3}$; government and schools, 0.75 million $\mathrm{m}^{3}$ ). This current usage represents approximately $40 \%$ of the maximum supply capacity. The Pasco system likewise draws from the 
TABLE 7.7. Examples of Physical Recreational Facilities Available in the Tri-Cities

Facilities

Tennis 62 outdoor courts (e.g., Sylvester Park, Howard Amon Park, Pasco High School). Indoor courts at Tri-City Court Club and Columbia Basin Racquet Club.

Golf Six courses including Tri-City Country Club, Canyon Lakes, and West Richland Municipal Golf Course. Several driving ranges and pro shops are also available.

Bowling Lanes in each city including Atomic Bowling Center, Clover Leaf Lanes, and Columbia Lanes.

Swimming Private (e.g., Ranchette Estates, Oasis Water Park) and public (e.g., Richland, Pasco, Kennewick) swimming pools $\mathrm{i} n$ the area. Boating, water-skiing and swimming on the Columbia River in the Tri-Cities area.

Ball Baseball fields and basketball courts are located throughout the Tri-Cities including Badger Canyon, Craighill Playgrounds, Stevens Playground and Lewis and Clark School. Soccer and football fields are also located in various areas.

Skating Rollerskating, iceskating, and skateboard facilities.

Camping Several hundred campsites within driving distance from the Tri-Cities area including Levy Park, Fishhook Park, and Sun Lakes.

Fishing Steelhead, sturgeon, trout, walleye, bass, and crappie fishing in the lakes and rivers near the Tri-Cities area.

Hunting Duck, geese, pheasant, and quail hunting. Deer and elk hunting in the Blue Mountains and the Cascade Range.

Source: Watson et al. (1984).

Columbia River for its water needs. The 1988 estimates of production were about 7.6 million $\mathrm{m}^{3}$. The Kennewick system uses two wells and the Columbia River for its supply. These wells serve as the sole source of water between November and March and can provide approximately $60 \%$ of the total maximum supply of 33.2 million $\mathrm{m}^{3}$. The 1988 usage was billed at 13.4 million $\mathrm{m}^{3}$ and represents approximately $40 \%$ of maximum supply capacity. 
The major incorporated areas of Benton and Franklin counties are served by municipal waste-water treatment systems, whereas the unincorporated areas are served by onsite septic systems. Richland's waste-water treatment system is designed to treat a total capacity of $27 \mathrm{mill}$ ion $\mathrm{m}^{3} / \mathrm{yr}$. Recently constructed, the system currently processes more than $6.3 \mathrm{million} \mathrm{m}^{3} / \mathrm{yr}$. The Kennewick system, similarly, has significant excess capacity. With a treatment capability of 12 million $\mathrm{m}^{3} / \mathrm{yr}$, current usage is just over $57 \%$ at 6.9 million $\mathrm{m}^{3}$ annually. Pasco's waste-treatment system processes over 6.9 million $\mathrm{m}^{3}$ each year while the system could treat 34.6 million $\mathrm{m}^{3}$.

\subsubsection{Electricity}

In the Tri-Cities, electricity is provided by the Benton County Public Utility District, the Benton Rural Electrical Association, the Franklin County Public Utility District, and the City of Richland Energy Services Department. All of the power that these utilities provide in the local area is purchased from the Bonneville Power Administration (BPA), a federal power marketing agency. The average rate for residential customers served by the three local utilities is roughly $\$ 0.035 / \mathrm{kWh}$. Electrical power for the Hanford Site is purchased wholesale from the BPA. Energy requirements for the Hanford Site during FY 1988 exceeded 550 average MW.

As of June 1989, 3,100 residential customers were using natural gas in the Tri-Cities.

In the Pacific Northwest, hydropower, and to a lesser extent, coal and nuclear power make up the region's electrical generation system. Total nameplate generating capacity is about 43,360 MW. Approximately $75 \%$ of the region's installed generating capacity is hydroelectric, which supplies approximately $70 \%$ of the electricity used by the region. Coal-fired generating capacity is $6,300 \mathrm{MW}$ in the region, or $15 \%$ of the region's electrical generating capacity. Oil and natural gas account for about 1,540 MW of capacity. The Hanford Generating Project had been operated with steam produced by the $\mathbf{N}$ Reactor, and provided 800 MW (net) until the N Reactor was shut down.

The region's electrical power system, more than any other system in the nation, is dominated by hydropower. On average, the region's hydropower 
system can produce $16,400 \mathrm{MW}$. Variable precipitation and limited storage capabilities alter the system's output from 12,300 average megawatts under critical water conditions to 20,000 average megawatts in record high water years. The Pacific Northwest system's reliance on hydroelectric power means that it is more constrained by the seasonal variations in peak demand than in meeting momentary peak demand.

In 1988, the surplus was about 1,400 MW, based on medium estimates. This surplus has been decreasing quickly, dropping 1,100 MW between 1986 and 1988. The projects currently under construction in the Northwest include about 150 MW of new capacity (Northwest Power Planning Council 1988).

\subsection{LAND USE}

The Hanford Site encompasses $1,450 \mathrm{~km}^{2}$ and includes several DOE operational areas. The major areas are as follows:

- The entire Hanford Site has been designated a National Environmental Research Park (NERP).

- The 100 Areas, bordering on the right bank (south shore) of the Columbia River, are the sites of the eight retired plutonium production reactors and the $\mathrm{N}$ Reactor, which is currently in wet 1ayup. The 100 Areas occupy about $11 \mathrm{~km}^{2}$.

- The 200-West and 200-East Areas are located on a plateau about 8 and $11 \mathrm{~km}$, respectively, from the Columbia River. These areas have been dedicated for some time to fuel reprocessing and waste processing management and disposal activities. The 200 Areas cover about $16 \mathrm{~km}^{2}$.

- The 300 Area, located just north of the City of Richland, is the site of nuclear research and development. This area covers $1.5 \mathrm{~km}^{2}$.

- The 400 Area is about $8 \mathrm{~km}$ north of the 300 Area and is the site of the Fast Flux Test Facility used in the testing of breeder reactor systems. Also included in this area is the Fuels and Material Examination Facility.

- The 600 Area includes all of the Hanford Site not occupied by the 100, 200, 300, or 400 Areas. Land uses within the 600 Area incl ude: 
- $310 \mathrm{~km}^{2}$ for the ALE reserve, which has been set aside for ecological studies.

- $4 \mathrm{~km}^{2}$ leased by Washington State, a part of which is used for commercial low-1evel radioactive waste disposal.

- $4.4 \mathrm{~km}^{2}$ for WPPSS nuclear power plants.

- $2.6 \mathrm{~km}^{2}$ transferred to Washington State as a potential site for the disposal of nonradioactive hazardous wastes.

- About $130 \mathrm{~km}^{2}$ under revocable use permit to the U.S. Fish and Wildlife Service for a wildlife refuge.

- $225 \mathrm{~km}^{2}$ under revocable use permit to the Washington State Department of Game for recreational game management.

- Support facilities for the controlled access areas.

Surrounding the operational areas of Hanford Site, $665 \mathrm{~km}^{2}$ have been designated as buffer zones and are used for the ALE Reserve, the U.S. Fish and Wildlife Service, wildlife refuge, and the Washington State Department of Game management area (DOE 1986).

Land use in other areas includes urban and industrial development, irrigated and dry-land farming, and grazing. In 1985, wheat represented the largest single crop in terms of area planted in Benton and Franklin counties with 116,000 hectares. Corn, alfalfa, hay, barley, and grapes are other major crops in Benton and Franklin counties.

In 1986, the Columbia Basin Project, a major irrigation project to the north of the Tri-Cities, produced gross crop returns of $\mathbf{\$ 3 4 3}$ million, representing 19\% of all crops grown in Washington State. In 1986, the average gross crop value per irrigated acre was $\$ 664$. The largest percentage of irrigated acres produced: alfalfa hay, $29.4 \%$ of irrigated acres; wheat, $15.0 \%$, corn (feed grain), 9.4\%. Other significant crops are potatoes, apples, dry beans, asparagus, and pea seed.

\subsection{OFFSITE HISTORICAL AND CULTURAL SITES}

Currently, 16 archeological properties are located near the Hanford Site. These properties are listed in the National Register of Historic 
Places. Table 7.8 lists the historic places in counties adjacent to the Hanford Site (see Chapter 6.0 for a detailed discussion of historical, archaeological, and cultural resources).

\subsection{VISUAL RESOURCES}

The land in the vicinity of the Hanford Site is generally flat with little relief. Rattlesnake Mountain, rising to 1,060 m above MSL, forms the western boundary of the site, and Gable Mountain and Gable Butte are the highest land forms within the site. Both the Columbia River, flowing across the northern part of the site and forming the eastern boundary, and the spring-blooming desert flowers provide a visual source of enjoyment to people.

TABLE 7.8. Washington State Register of Historic Places in Benton and Franklin Counties

\section{Benton County}

Benton County Courthouse, Prosser

Glade Creek Site, Prosser vicinity

Telegraph Island Petroglyphs, Paterson vicinity

Charles Conway House, Kennewick

Frankl in County

Ainsworth, Pasco vicinity

Allen Rockshel ter, Pasco vicinity

Burr Cave, Walker vicinity

Franklin County Courthouse, Pasco

Marmes Rockshelter, Lyons Ferry vicinity

James Moore House, Pasco

Palouse Canyon Archaeological District, Lower Palouse River vicinity

Pasco Carnegie Library, Pasco

Strawberry Island Village, Pasco vicinity

Tri-Cities Archaeological District, Pasco vicinity

Windust Caves Archaeological District, Ice Harbor Reservoir, Snake River

Source: Watson et al. (1984). 


\subsection{NOISE}

Noise is technically defined as unwanted sound waves perceptible to the human ear. Sound waves are characterized by frequency, measured in Hertz $(\mathrm{Hz})$, and sound pressure expressed as decibels $(\mathrm{dB})$. Humans have a percepti ble hearing range of about 30 to $20,000 \mathrm{~Hz}$. The decibel is a value equal to 10 times the logarithm of the ratio of a sound pressure squared to a standard reference sound pressure level (20 micropascals) squared. The threshold of audibility ranges from about $60 \mathrm{~dB}$ at a frequency of $31 \mathrm{~Hz}$ to about less than $1 \mathrm{~dB}$ between 900 to $8,000 \mathrm{~Hz}$. For regulatory purposes, noise levels for perceptible frequencies are weighted to provide an A-weighted sound level (dBA). Sound pressure levels outside the range of human hearing are not considered noise in a regulatory sense, even though wildlife may be able to hear at these frequencies.

Noise levels are often reported as the equivalent sound level (Leq). The Leq is expressed in dBA over a specified period of time, usually 1 or 24 hours. The Leq expresses time-varying noise levels by integrating noise levels over time and expressing them at a steady-state continuous sound 1evel.

\subsection{BACKGROUND NFORMATION}

Studies at Hanford dealing with the propagation of noise have dealt primarily with occupational noise at work sites. Environmental noise levels have not been extensively evaluated because of the remoteness of most Hanford activities and isolation from receptors that are covered by federal or state statutes. This discussion will focus on what little environmental noise data is available. The majority of available information consists of model predictions, which in many cases were not verified because the predictions indicated that the potential to violate state or federal standards was remote or unreal istic. 


\subsection{ENVIRONMENTAL NOISE REGULATIONS}

The Noise Control Act of 1972 and its subsequent amendments (Quiet Communities Act of 1978; 42 USC 4901-4918; 40 CF 201-211) directs the regulation of environmental noise to the state. Washington State has adopted FON 70.107, which authorizes Ecology to implement rules consistent with federal noise control legislation. RCW 70.107 and the implementing regulations embodied in WC 173-60 through 173-70 defined the regulation of environmental noise levels. Maximum noise levels are defined for the zoning of the area for environmental designation for noise abatement (EDNA). The Hanford Site is classified as a Class $C$ EDNA on the basis of industrial activities. Unoccupied areas are also classified as Class $C$ areas by default because they are neither Class A (residential) nor Class B (commercial). Maximum noise levels are established based on the ENA classification of the receiving area and the source area (Table 8.1). For compliance purposes, the receptor criteria are evaluated at the Hanford Site boundary.

\subsection{HANFORD SITE SOUND LEVELS}

Most industrial facilities on the Hanford Site are located far enough away from the site boundary that noise levels at the boundary are not measurable or are barely distinguishable from background noise levels. Modeling of environmental noises has been performed for commercial reactors and for State Highway 240 through the Hanford Site. These data do not deal with background levels of noise and are not reviewed here. There are two sources of measured environmental noise at Hanford. Environmental noise measurements were made in 1981 during site characterization of the Skagit/Hanford Nuclear Power Plant Site (NRC 1982). The Hanford Site was considered as the site for

TABLE 8.1. Applicable State Noise Limitations for the Hanford Site Based on Source and Receptor EDNA Designation (values are $d B A$ )

\begin{tabular}{|c|c|c|c|}
\hline \multirow[b]{2}{*}{$\begin{array}{c}\text { Source } \\
\text { Hanford Site }\end{array}$} & \multicolumn{3}{|c|}{ Receptor } \\
\hline & $\begin{array}{r}\text { Class A } \\
\text { Residential }\end{array}$ & $\begin{array}{c}\text { Class B } \\
\text { Comrnercial }\end{array}$ & $\begin{array}{c}\text { Class C } \\
\text { Industrial }\end{array}$ \\
\hline $\mathrm{Da}$ & 60 & 65 & 70 \\
\hline $\mathrm{Nig}$ & 50 & -- & -. \\
\hline
\end{tabular}


a geologic waste repository (BWIP) for spent commercial nuclear fuel and other high-level nuclear waste (HLW). Site characterization studies performed in 1987 included measurement of background environmental noise levels at five sites on the Hanford Site. (a)

\subsubsection{Skaqit/Hanford Data}

Preconstruction measurements of environmental noise were taken in June 1981 on the Hanford Site (see Figure 8.1). Fifteen sites were monitored, and noise levels ranged from 30 to $60.5 \mathrm{dBA}$ (Leq). The values for isolated areas ranged from 30 to $38.8 \mathrm{dBA}$. Measurements taken around the sites where WPPSS was constructing nuclear power plants (WNP-1, -2, and -4) ranged from 50.6 to $64 \mathrm{dBA}$. Measurements taken along the Columbia River near the intake structures for WNP-2 were 47.7 and $52.1 \mathrm{dBA}$ compared to more remote river noise levels of $45.9 \mathrm{dBA}$ (measured about $5 \mathrm{~km}$ upstream of the intake structures). Community noise levels in North Richland (the 3000 Area at Horn Rapids Road and the By-Pass Highway) were $60.5 \mathrm{dBA}$.

\subsubsection{BWIP Data}

Background noise levels were determined at five undeveloped sites located within the Hanford Site. Noise levels are expressed as equivalent sound levels for 24 hours (Leq-24). Sample location (see Figure 8.1), date, and Leq-24 are listed in Table 8.2. Wind was identified as the primary contributor to background noise levels with winds exceeding $20 \mathrm{~km} / \mathrm{hr}$ significantly affecting noise levels. Wind speeds of up to $37 \mathrm{~km} / \mathrm{hr}$ resulted in increases of background noise from about $35 \mathrm{~dB}(A)$ to about $60 \mathrm{~dB}(\mathrm{~A})$. (a) Studies conclude that background noise levels in undeveloped areas at Hanford can best be described as a mean Leq-24 of 24 to $36 \mathrm{dBA}$. Periods of high wind, which normally occur in the spring, would elevate background noise levels. (a)

\subsubsection{NPR Site Data}

The proposed NPR site is located in Section 33, Township $12 \mathrm{~N}$, Range $27 \mathrm{E}$. The primary sources of noise in this area may be attributed to

(a) Coleman, S. R. 1988. Environmental Noise Monitoring. BWIP Site. Characterization Project. Letter Report C0-12023 to D. D. Dauble, Pacific Northwest Laboratory, Richland, Washington, February 18, 1988. 


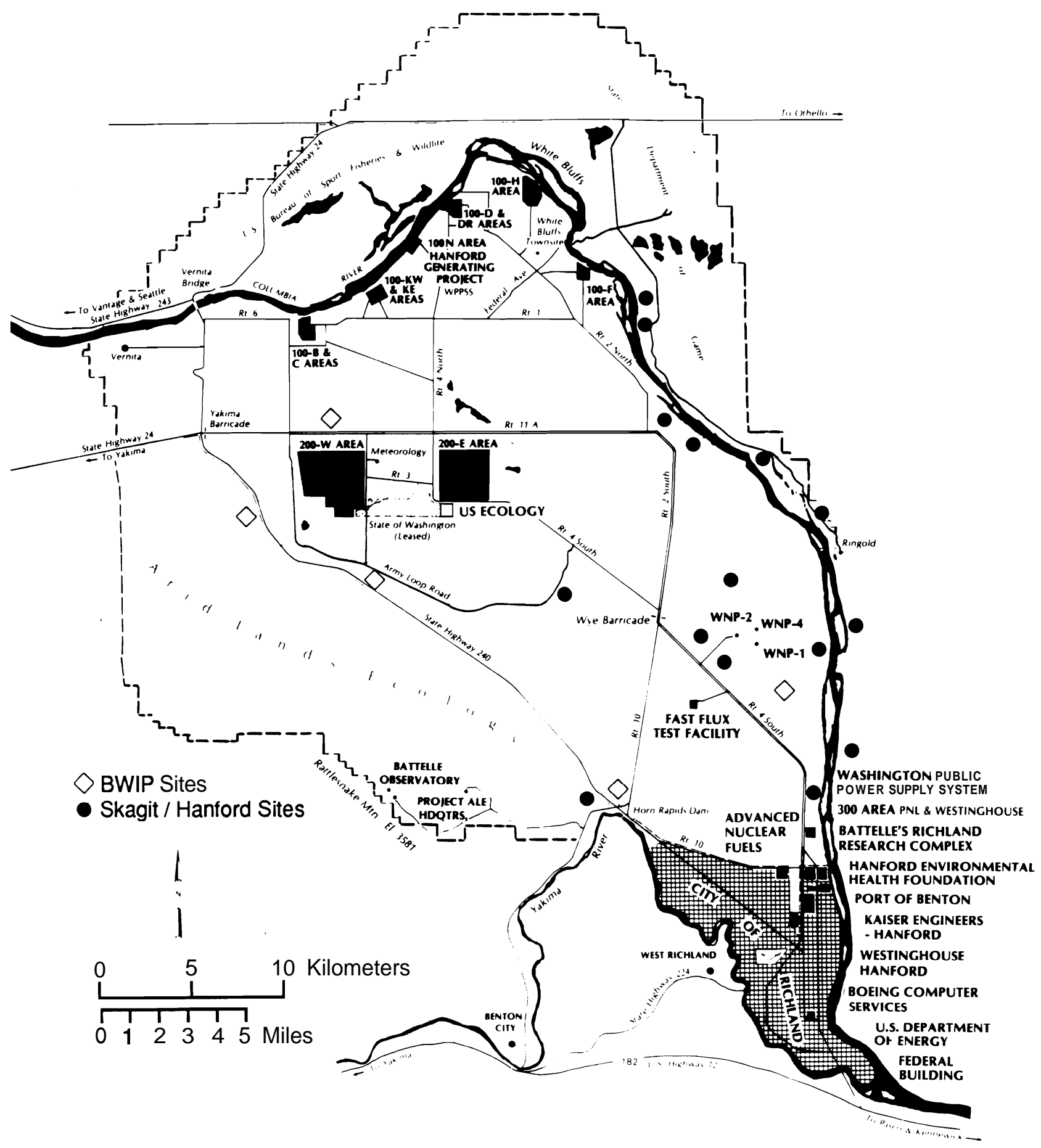

FIGURE 8.1. Noise Measurement (24 hr Leq) Locations on the Hanford Site 
TABLE 8.2. Background Noise Levels Measure at Isolated Areas

\begin{tabular}{|c|c|c|c|c|c|}
\hline & & Locat & & & \\
\hline Site & $\underline{\text { Sec. }}$ & Ranqe & Township & Date & Leq-24 (dBA) \\
\hline 1 & 9 & R25E & $\mathrm{T} 12 \mathrm{~N}$ & $\begin{array}{l}07-10-87 \\
07-11-87 \\
07-12-87 \\
07-13-87 \\
07-14-87\end{array}$ & $\begin{array}{l}41.7 \\
40.7 \\
36.0 \\
37.2 \\
35.6\end{array}$ \\
\hline 2 & 26 & R25E & T13N & $\begin{array}{l}07-25-87 \\
07-26-87 \\
07-27-87 \\
07-28-87 \\
07-29-87\end{array}$ & $\begin{array}{l}43.9 \\
38.8 \\
43.8 \\
37.7 \\
43.2\end{array}$ \\
\hline 3 & 18 & R26E & T12N & $\begin{array}{l}08-08-87 \\
08-09-87 \\
08-10-87 \\
08-11-87 \\
08-12-87\end{array}$ & $\begin{array}{l}39.0 \\
35.4 \\
51.4(a) \\
56.7(a) \\
36.0\end{array}$ \\
\hline 4 & 34 & R27E & T11N & $\begin{array}{l}09-09-87 \\
09-10-87 \\
09-11-87 \\
09-12-87 \\
09-13-87\end{array}$ & $\begin{array}{l}35.2 \\
34.8 \\
36.0 \\
33.2 \\
37.3\end{array}$ \\
\hline 5 & 14 & R28E & T11N & $\begin{array}{l}10-15-87 \\
10-16-87 \\
10-17-87 \\
10-18-87 \\
10-19-88\end{array}$ & $\begin{array}{l}40.8 \\
36.8 \\
33.7 \\
31.3 \\
35.9\end{array}$ \\
\hline
\end{tabular}

(a) Leq includes grader noise.

automobile traffic on both Highway $4 \mathrm{~S}$ to the north and Army Loop Road to the west, and operations at the waste disposal site approximately $2.5 \mathrm{~km}$ to the west. Noise measurements taken in the vicinity of the proposed NPR site indicate that normal background levels of noise range from 30 to $39 \mathrm{~dB}(\mathrm{~A})$. Noise measurements obtained from isolated areas registered levels expressed as a Leq-24 of 31.3 to $40.3 \mathrm{db}(A)$. Isolated areas include Skagit/Hanford sites 10, 11, and 12 and BWIP sites 4 and 5 (see Figure 8.1). 



\subsection{MONITORING AND MITIGATION PROGRAMS}

In accordance with DOE Order 5400.1, the DOE monitors the Hanford Site environment and reports the results on an annual basis. The policy of the DOE is to operate its facilities such that radiation doses to members of the public are maintained as low as reasonably achievable (ALARA), A primary purpose of environmental monitoring is to estimate and assess radiation doses to individuals and groups of individuals (i.e., populations) who potentially could be exposed to radioactive materials and radiation in the environment from present and past operations of Hanford facilities. Another purpose of environmental monitoring is to determine concentrations and assess potential impacts of nonradiological materials in the environment. A third purpose is to detect and assess any increasing trends in environmental radiation dose rate and in radioactive and nonradioactive material concentrations found in various kinds of environmental samples that may result from Hanford operations. The final purpose is to inform the public as well as federal, state, and local regulatory agencies of changes in the radiological and nonradiological status of the environment.

\subsection{SCOPE}

The scope of environmental monitoring at Hanford encompasses all potential effluents, including chemical and radioactive materials. Monitoring activities are selected to be responsive to both routine and potential releases of effluents according to the severity of possible impact on the environment or public health. Activities also provide a feedback system to evaluate the adequacy and effectiveness of containment and effluent control systems. The DOE and the appropriate facility manager are notified if offstandard conditions or adverse trends are detected in the environment near operating areas.

\subsection{OBJECTIVES}

The objectives of the monitoring program include the following:

- assessing environmental impacts to the offsite public from Hanford Site operations 
- verifying that in-plant controls for the containment of radioactive and nonradioactive materials within controlled areas ( $\mathbf{i}$ e., on the site) are adequate

- monitoring to determine potential buildup of long-1 ived radionuclides in uncontrolled areas (i.e., off the site)

providing information to regulatory agencies and the public that helps assess operational impacts and identify noteworthy changes in the radiological and nonradiological status of the environment.

\subsection{PROGRAM DESCRIPTION}

Environmental monitoring provides for the measurement and interpretation of the impact of Hanford operations on the public and the onsite and offsite environment. The program is designed to examine all significant exposure pathways. Radiological impacts are expressed in terms of annual effective dose equivalent. Numerous samples are collected and analyzed according to a schedule.

Table 9.1 summarizes the geographic distribution of sample types and measurement locations. Schedules, records, and data are maintained in a computer system.

Environmental samples collected for measurement of chemical and radionuclide content were analyzed by U.S. Testing Company, Inc., Richland, Washington. Analysis of environmental dosimeters for penetrating radiation are performed by PNL. Groundwater sample analyses are performed by PNL's analytical laboratories, the Hanford Environmental Health Foundation (HEHF), and U.S. Testing Company. Water quality, temperature, and flow rates for the Col umbia River are determined by the U.S. Geologic Survey (USGS) . Quality assurance (QA) is an integral part of the program.

\subsection{RELATED PROGRAMS, SPECIAL STUDIES, AND REPORTS}

There are a number of other programs and special studies that relate to site-wide environmental monitoring. 
TABLE 9.1. Environmental Sample Types and Measurement Locations, 1987 Sample Types

\begin{tabular}{lccc}
\multicolumn{3}{c}{ Sample Locations } \\
\hline Total & Nearby & Distant \\
Number & nnsite & Perimeter Communities & Communities
\end{tabular}

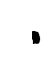

Air
Groundwater
Col umbia River
Irrigation Water
Drinking Water
Ponds
Foodstuffs
Wildlife
Soil and Vegetation
Dose Rate
Waste Site Surveys
Rai Troad/Roadway/Surveys
Shoreline Survey

$\begin{array}{rrrrr}50 & 21 & 14 & 9 & 6 \\ 563 & 563 & -- & -- & -- \\ 3 & -- & 2 & 1 & -- \\ 1 & -- & 1 & -- & -- \\ 8 & -- & -- & -- & -- \\ 4 & 4 & -- & -- & -- \\ 8 & -- & 5 & 1 & 2 \\ 10 & 9 & 1 & -- & -- \\ 38 & 15 & 14 & 3 & 6 \\ 91 & 31 & 46 & 9 & 6 \\ 72 & 72 & -- & -- & -- \\ 16 & 16 & -- & -- & -- \\ 14 & -- & 14 & -- & --\end{array}$

\subsubsection{Operating Areas Monitoring}

The Westinghouse Hanford Company (WHC), the operating and engineering contractor for the Hanford Site, measures and records the amounts of liquids, gases, and solids and the concentrations of radionuclide and hazardous substances contained in effluents released to the environment. Westinghouse Hanford Company takes environmental measurements near facilities to audit the control of environmental releases and the general conditions of the local environment. These measurements supplement the extensive onsite and offsite monitoring done by PNL. An annual environmental report is published by WHC.

\subsubsection{Drinking Water Monitoring}

Drinking water is supplied to DOE-operated facilities on the Hanford Site by 19 separate systems. Fourteen of the systems use Columbia River water as a raw-water source, four systems use groundwater, and one system (the City of Richland) uses a combination of river water and groundwater. Monitoring of the drinking water on the Hanford Site is a joint effort between HEHF and PNL, with HEHF specializing in the areas of chemical and 
microbiological quality and PNL focusing on radiological quality. The primary purpose for the surveillance of Hanford Site drinking water is to determine if the quality of the water complies with federal and state drinking water standards. Results of the drinking water surveillance program are reported annually by HEHF with contributions from PNL.

\subsubsection{Resource Conservation and Recovery Act (RCRA) Monitoring}

Established by the U.S. Congress in 1976, RCRA requires a comprehensive program to regulate and monitor the movement of hazardous wastes from generation to final disposal. One aspect of RCRA involves groundwater monitoring at waste facilities. Groundwater monitoring programs designed to comply with RCRA are conducted at the 183-H Solar Evaporation Basins in the 100-H Area, the 300 Area Process Trenches, and the LLW Burial Grounds in the 200 Areas. A detection-1 evel groundwater monitoring program began in 1986 at the Nonradioactive Dangerous Waste (NRDW) Landfill, $5 \mathrm{~km}$ southeast of the 200-East Area. Well installation at the Solid Waste Landfill immediately adjacent to the NRDW Landfill, was completed in 1987, after which a detection-level monitoring program was initiated.

\subsubsection{Comprehensive Environmental Response, Compensation, and Liability Act (CERCLA) Assessments}

The CERCLA, as amended by the Superfund Amendments and Reauthorization Act of 1986, provides for liability, compensation, cleanup, and emergency response for hazardous substances released to the environment and the cleanup of inactive hazardous waste sites, including those sites on federal installations. Assessment activities for compliance with CERCLA are performed under the Inactive Waste Site Surveillance Project. Work consists of identifying, investigating, and ranking engineered-facility and unplanned release sites. The Hanford Inactive Site Surveillance Database was updated to reflect the current ranking of each site. Level 1 Remedial Investigation Work Plans were developed for the Strontium Semiworks, 1iquid-waste disposal sites, and the 300 Area process ponds under DOE Order 5480.1A directives. 


\subsubsection{Nonradioloqical Air Monitoring}

Nonradiological pollutants released to the atmosphere from chemicalprocessing plants and fossil-fueled steam plants at Hanford consist primarily of nitrogen oxides $\left(\mathrm{NO}_{\mathrm{X}}\right)$. The HEHF operates a 9-station network to sample ambient air nitrogen dioxide $\left(\mathrm{NO}_{2}\right)$.

9.4.6 Wildlife Census

The purpose of the wildlife census is to determine the population status of a few key wildlife and fish species that inhabit the Hanford Site. Information on populations of spawning chinook salmon and nesting Canada geese has been obtained for 33 consecutive years. Aerial censuses of the American bald eagle, which is a "threatened" species in Washington State, have been obtained since the 1960s. In recent years, the status of nesting hawks, long-billed curlews, and great blue herons has been added to the wildlife census. In general, the conservative use of the land and water resources of the Hanford Site has benefited indigenous wildlife species. The number of spawning salmon has increased in recent years in response to fisheries management practices. The number of bald eagles that forage but do not nest in the area has also increased because of the increased food supply of spawned-out, dead salmon. The population of nesting geese has remained relatively stable.

\subsection{AIR MONITORING}

The transport by wind of atmospheric releases of radioactive and nonradioactive materials from Hanford to the surrounding region represents a direct pathway for human exposure. The radioactive materials in air are sampled continuously on the site, at the site perimeter, and in nearby and distant communities at 50 locations. Particulates filtered from the air at all locations are analyzed for radionuclides. Air is sampled and analyzed for selected gaseous radionuclides at selected locations. Nitrogen dioxide is sampled at eight onsite locations and one offsite location.

Many of the radionuclides released to the environment at Hanford are also found worldwide from two other sources: those that are naturally occurring and those resulting from worldwide nuclear weapons testing fallout. 
Those samples collected at distant community locations within the region essentially only contain contributions from natural and fallout sources, as evidenced by comparison with data obtained before restart of the PUREX Plant and by comparison with EPA data from locations outside the region. The influence of Hanford emissions on local radionucl ide levels is indicated by the difference between concentrations measured at distant community locations within the region and concentrations measured closer to the site (PNL 1990).

\subsection{GROUNDWATER MONITORING}

Radiological and chemical constituents in groundwater are monitored throughout the Hanford Site in support of the overall objectives. Monitoring activities are conducted to 1 ) determine the distribution of mobile radionuclides and $\mathrm{NO}_{3}$, 2) relate the distribution of these constituents to site operations, and 3) identify chemicals in groundwater as a result of site operations. Additional monitoring is conducted by PNL to assess the impact that specific facilities have had on the groundwater quality to comply with RCRA. The evaluation of the quality of the groundwater in the 200 Areas and surrounding region is conducted by PNL for WHC. This evaluation is to ensure compliance with DOE monitoring guidelines, to assess the performance of waste disposal and storage, and to determine the impacts of operations on the groundwater. Samples from a total of 563 wells, primarily open to the unconfined (shall ow) aquifer, were col lected and analyzed during 1987.

Analytical results for samples are compared to the EPA drinking water standards (DWS) and the DOE derived concentration guide (DCG). These standards were written for drinking water, and while none of the wells are drinking water supply wells, they provide a basis for evaluating levels of contamination. Groundwater beneath the Hanford Site is used for drinking water at four locations, the FFTF, the rifle range, the Yakima barricade, and the observatory on Rattlesnake Mountain.

The primary source of groundwater contamination is liquid waste released to the soil column by past and ongoing site operations. Both active and inactive waste disposal sites contributed to the radionuclide and chemical contamination detected. 


\subsection{SURFACE-WATER MONITORNG}

The Columbia River is one of the primary environmental pathways to the public as a result of operations at Hanford. Radiological and nonradiological contaminants enter the river along the Hanford reach as direct effluent discharges and through the seepage of contaminated groundwater. Water samples are collected from the river at various locations throughout the year to determine compliance with applicable standards.

Although radionuclides associated with Hanford operations continue to be routinely identified in Col umbia River water, concentrations have remained extremely low at a11 locations, and are we 11 below appl icable standards. Nonradiological water quality constituents measured in Columbia River water are also in compl iance with applicable standards.

Four onsite ponds are also sampled to determine radionucl ide concentrations. These ponds are accessible to migratory waterfowl and other animals. As a result, a potential biological pathway exists for the removal and dispersal of contaminants that may be in the ponds.

\subsection{FOOD AND FARM PRODUCT MONITORNG}

Alfalfa and several foodstuffs, including mik, vegetables, fruits, wine, beef, chickens, eggs, and wheat, are collected at several locations in the prevailing downwind directions (i.e., to the south and east of the site). Samples are also collected in generally upwind directions somewhat distant from the site to provide information on levels of radioactivity that could be attributed to worldwide fallout. Some foodstuffs from the Riverview area are irrigated with water pumped from the Columbia River downstream of the site. Most samples are analyzed for strontium-90 and cesium-137. Wine samples are analyzed for tritium and cesium-137. Wheat samples are analyzed for strontium-90, cesium-137, and plutonium-239, 240.

\subsection{WILDLIFE MONITORING}

The Hanford Site serves as a refuge for waterfowl, upland game birds, and various terrestrial animals. Wild life have access to several areas near facilities that contain low levels of radionucl ides attributable to site 
operations (e.g., waste-water ponds) and serve as biological indicators of environmental contamination. Sampling is performed in areas where the potential exists for wildlife to ingest radionuclides. The number of animals that visit these areas is small compared with the total wildlife population in the region. Fish are collected from the Hanford reach of the Columbia River. Analyses provide an indication of the radionuclide concentrations in local game fish and are used to evaluate the potential dose to humans from this pathway.

\subsection{SOIL AND VEGETATION MONITORING}

Surface soil and rangeland vegetation samples are collected at a number of locations, both on and off the site. The purpose of sampling is to detect the buildup of radionuclides from the deposition of airborne effluents released from Hanford facilities. Samples are collected at nonagricultural, undisturbed sites so that natural deposition and buildup processes are represented. Because the radionuclides of interest are present in worldwide fallout or occurred both naturally and in Hanford effluents, their presence at some levels is expected in all samples.

Assessment of radionuclide contribution from Hanford operations is made by comparing results from samples collected 1) onsite with those collected offsite, 2) around the site perimeter with those collected at distant locations, and 3) downwind (primarily east and south of the site) with those collected from generally upwind and distant locations. In addition, results obtained from each location are compared with results obtained from the same location in previous years.

\subsection{PENETRATING-RADIATION MONITORING}

Dose rates from penetrating radiation (gamma rays) are measured at a number of locations in the Hanford environs. Measurements are made using thermoluminescent dosimeters to provide estimates of the dose rates from external radiation sources. Penetrating radiation from naturally occurring sources, including cosmic radiation and natural radioactive materials in the air and ground, as well as worldwide fallout, is recorded at all dosimeter 
locations. Dosimeters also measure dose rates from exposure to radioactive materials associated with activities at Hanford.

Radiation surveys are conducted at numerous locations on the Hanford Site. Onsite roads, railroads, and retired waste-disposal sites located outside of operating areas are routinely surveyed. These surveys are designed to identify areas where levels of radioactivity are abnormal.

\subsection{MITIGATION}

An extensive preoperational and operational monitoring program has been conducted for WNP-2. Data from these studies have demonstrated the negligible impact of plant operations on the environment. No significant environmental impacts from siting, construction, operation, and decommissioning of the NPR and related support facilities are anticipated based on Hanford Site historical experience. Since so few impacts have been found in the first 5 years of operations, Washington State has concurred in the discontinuance of much of the environmental monitoring program associated with the WNP-2 site.

Extensive and continuing efforts have been made at Hanford to model the movement of various contaminants in the environment and to determine the characteristics of their transport from source to ultimate fate.

No natural surface waters occur on the proposed site. 
Beak Consultants Inc. 1980. Aauatic Ecological Studies Near WNP-1, 2 and 4. Auqust 1978-March 1980. WPPSS Columbia River Ecology Studies, Volume 7. prepared for Washington Public Power Supply System by Beak Consultants Inc.,

Brown, D. J. 1960. An Eolian Deposit Beneath 200-West Area. HW-67549, General Electric Company, Richland, Washington.

Cadoret, N. A and J. C. Chatters. 1988. Cultural Resources Survev of the Proposed 400-Area Sanitary Sewer Site. HCRC \#87-400-001. Letter report submitted to the U.S. Department of Energy, Richland Operations, Richland, Washington.

Catchings, R. D., and W. D. Mooney. 1988. "Crustal Structure of the Columbia Plateau: Evidence for Continental Rifting. " Journal of Geophysical Research, 93:459-474.

Chatters, J. C. 1989. Hanford Cultural Resources Manasement Plan.

PNL-6942, Pacific Northwest Laboratory, Richland, Washington.

Coony, F. M., and S. P. Thomas. 1989. Westinghouse Hanford Company Effluent Releases and Solid Waste Management Report for 1988: 200/600 Areas. WHCEP-0141-1, Westinghouse Hanford Company, Richland, Washington.

Couch, R., G. Thrasher, and K. Keeling. 1976. "The Deschutes Valley Earthquake of April 12, 1976." The Ore Bin, 38(10): 151-161.

Cushing, C. E., Jr. 1967a. "Concentration and Transport of Phosphorus-32 and Zinc-65 by Columbia River Plankton." Limnol. Oceanoar. 12:330-332.

Cushing, C. E., Jr. 1967b. "Periphyton Productivity and Radionuclide Accumulation in the Columbia River, Washington, U.S.A. " Hvdrobiolosia 29: $125-139$.

Cushing, C. E., C. D. McIntire, J. R. Sedell, K. W. Cummins, G. W. Minshall, R. C. Petersen, and R. L. Vannote. 1980. "Comparative Study of PhysicalChemical Variables of Streams Using Multivariate Analyses." Arch. Hvdrobiologia 89(3):343-352.

Cushing, C. E., and E. G. Wolf. 1984. "Primary Production in Rattlesnake Springs, a Cold Desert Spring-Stream." Hvdrobiolosia 114:229-236.

Cushing, C. E. 1988. Hanford Site National Environmental Policv Act (NEPA) Characterization. PNL-6415, Rev. 1, Pacific Northwest Laboratory, Richland, Washington.

Daubenmire, R. 1970. "Steppe Vegetation of Washington." Tech. Bull. 62, Exp. Sta., Washington State University, Pullman, Washington. 
Emery, R. M., and M. C. McShane. 1980. "Nuclear Waste Ponds and Streams on the Hanford Site: An Ecological Search for Radiation Effects." Health

Phvsics 38:787-809.

ERTEC. 1982. A Cultural Resources Overview and Scenic and Natural Resources Assessment for the Skaqit-Hanford Nuclear Power Project. ERTEC Northwest, Seattle, Washington.

Evergreen Community Development Association. 1986. Tri-Cities Enterprise Center Business Development Plan. Richland, Washington.

Fitzner, R. E., and K. R. Price. 1973. The Use of Hanford Waste Ponds by Waterfowl and Other Birds. BNWL-1738, Pacific Northwest Laboratory, Richland, Washington.

Fitzner, R. E., and W. H. Rickard. 1975. Avifauna of Waste Ponds, EDA Hanford Reservation, Benton Countv. Washington. BNWL-1885, Pacific Northwest Laboratory, Richland, Washington.

Fitzner, R. E., and R. G. Schreckhise. 1979. Nesting Biologv. Part 1 of the American Coot (Fulica americana) on the Hanford Site. PNL-2462, Pacific Northwest Laboratory, Richland, Washington.

Fitzner, R. E., W. H. Rickard, L. L. Cadwe11, and L. E. Rogers. 1980. Raptors of the Hanford Site and Nearbv Areas of Southcentral Washington.

PNL-3212, Pacific Northwest Laboratory, Richland, Washington.

Gaines, W. E. 1987. Secondarv Production of Benthic Insects in Three Cold-Desert Streams. PNL-6286, Pacific Northwest Laboratory, Richland, Washington.

Gano, K. A. and W. H. Rickard. 1982. "Small Mammals of a BitterbrushCheatgrass Community." Northwest Science, 56:1-7.

Gee, G. W., M. L. Rockhold and J. L. Downs. 1989. Status of FY 1988 SoilWater Studies on the Hanford Site. PNL-6750. Pacific Northwest Laboratory, Richland, Washington.

Glover, D. W. 1985. Crustal Structure of the Columbia Basin, Washington, from Borehole and Refraction Data. Master of Science Thesis, University of Washington, Seattle, Washington.

Graham, M. J., M. D. Hall, S. R. Strait, and W. R. Brown. 1981. Hvdrologv of the Separations Area. RHO-ST-42, Rockwell Hanford Operations, $\overline{R i c h l a n d,}$ Washington.

Gray, R. H., and D. D. Dauble. 1977. "Checklis t and Relative Abundance of Fish Species from the Hanford Reach of the Columbia River." Northwest Sci. $51: 208-215$. 
Grazul is, T. P. 1984. Violent Tornado Climatology, 1880-1082.

NUREG/CR-3670, Nuclear Regulatory Commission, Washington, D. C.

Gustafson, E. P. 1978. The Vertebrate Faunas of the Pliocene Ringold

Formation. South Central Washington. Museum of Natural History Bulletin 32, Universit y of Oregon, Eugene, Oregon.

Hajek, B. F. 1966. Soil Survev Hanford Project in Benton County Washinqton. BNWL-243, Pacific Northwest Laboratory, Richland, Washington.

Hanson, W. C., and L. L. Eberhardt. 1971. "A Columbia River Goose Population 1950- 1970." Wild1. Monogr. No. 28. Wildlife Society.

Jamison, J. D. 1982. Standardized Input for Hanford Environmental Impact Statements Part II: Site Descriptions. PNL-3509 Part 2, pp. 9.1-9.16., Pacific Northwest Laboratory, Richland, Washington

Klepper, E. L., L. E. Rogers, J. D. Hedlund, R. G. Schreckhise. 1979. Radioactivitv Associated with Biota and Soils of the 216-A-24 Crib. PNL-1948, Pacific Northwest Laboratory, Richland, Washington.

Ledgerwood, R. K, C. W. Myers and R. W. Cross. 1978. Pasco Basin Stratigraphic Nomenclature. RHO-BWI-LD-1, Rockwe11 Hanford Operations, Richland, Washington.

Leonhart, L. S. 1979. Surface Hvdrologic Investigations of the Columbia Plateau Reqion, Washington. RHO-BWI-ST-6, Rockwel1 Hanford Operations, Richland, Washington.

Malone, S. D., and S. Bor. 1979. "Attenuation Patterns in the Pacific Northwest Based on Intensity Data and the Location of the 1872 North Cascades Earthquake." Bulletin of the Seismological Societv of America, 69:531-546.

Mckee, E H., D. A. Swanson, and T. L. Wright. 1977. "Duration and Volume of Columbia River Basalt Volcanism: Washington, Oregon, and Idaho. " Geological Societv of America Abstracts with Programs, 9(4):463-464.

Morgan, V. 1981. Archaeological Reconnaissance of the North Richland Toll Bridge and Associated Access Roads (L6909). Archaeological and Historical Services, Eastern Washington University, Cheney, Washington.

Myers, C. W., S. M. Price, and J. A. Caggiano, M. P. Cochran, W. J. Czimer, N. J. Davidson, R. C. Edwards, K. R. Fecht, G. E. Holmes, M. G. Jones, J. R. Kunk, R. D. Landon, R. K. Ledgerwood, J. T. Lillie, P. E. Long, T. H. Mitchell, E H. Price, S. P. Reidel, and A. M. Tallman. 1979. Geologic Studies of the Columbia Plateau: A Status Report. RHO-BWI-ST-4, Rockwe11 Hanford Operations, Richland, Washington.

Napier, B. A. 1982. A Method for Determining "Allowable Residual Contamination Levels" of Radionuclide Mixtures in Soil. PNL-3852, Pacific Northwest Laboratory, Richland, Washington. 
Neitzel, D. A., T. L. Page, and R. W. Hanf, Jr. 1982a. "Mid-Columbia River Microflora." J. Freshwater Ecol. 1(5):495-505.

Neitzel, D. A, T. L. Page, and R. W. Hanf, Jr. 1982b. "Mid-Columbia River Zooplankton." Northwest. Sci. 57: 112-118.

Northwest Power Planning Counci1. 1988. 1986 Northwest Power Plan (as amended). Portland, Oregon.

Pacific Northwest Laboratory (PNL). 1989a. Hanford Site Environmental Report for Calendar Year 1988. PNL-6825, Pacific Northwest Laboratory, Richland, Washington.

Pacific Northwest Laboratory (PNL). 1989b. Hydrogeology of the 200 Areas Low-Level Burial Grounds--An Interim Reoort. PNL-6820, Pacific Northwest Laboratory, Richland, Washington.

Pacific Northwest Laboratory (PNL) . 1990. Hanford Site Environmental Report for Calendar Year 1989. PNL-7346, Pacific Northwest Laboratory, Richland, Washington.

Page, T. L., and D. A Neitzel. 1978. "Columbia River Benthic Macrofauna and Microfauna Near WP 1, 2, and 4: January through December 1977," Section 4. In Aauatic Ecological Studies Near WP 1.2. and 4. Januarv through December 1977. WPPSS Columbia River Ecology Studies Vol. 5. Battelle, Pacific Northwest Laboratories, Richland, Washington.

Page, T. L., D. A Neitzel, and R. W. Hanf. 1979. "Columbia River Benthic Macrofauna and Microflora Near WP 1, 2, and 4: January through August 1978," Section 4. In Aauatic Ecological Studies Near WP 1. 2. and 4. Januarv through Auqust 1978. WPPSS Columbia River Ecology Studies Vol. 6. Batte11e, Pacific Northwest Laboratories, Richland, Washington.

Ramsdell, J. V., and G. L. Andrews. 1986. Tornado Climatology of the Contiquous United States. NUREG/CR-4461, U.S. Nuclear Regulatory Commission, Washington, D.C.

Relander, C. 1956. Drummers and Dreamers. Caxton Printers, Caldwell, Idaho.

Rice, D. G. 1968. Archaeological Reconnaissance: Hanford Atomic Works. U.S. Atomic Energy Commission, National Park Service and Washington State University, Pullman, Washington.

Rice, D. G. 1972. Archaeological and Historical Reconnaissance, Washington Publi c Power Supply System Hanford No. 2 Reactor. Letter report submitted to Burns and Roe, Inc., dated September 13, 1972. 
Rice, D. G. 1974. Archaeological and Historical Reconnaissance at Relocated WNP-1. Letter report submitted to United Engineers and Constructors, Inc., dated May 9, 1974.

Rice, D. G. 1978. Archaeological Reconnaissance of the Wam Water Irrigation Project Lands. Letter report submitted to Richland Operations, U.S. Department of Energy, dated June 12, 1978.

Rice, H. S., D. H. Stratton and G. W. Lindeman. 1978. An Archaeological and Historic Survey of the 400 Area. Hanford Reservation. National Heritage, Inc., Pullman, Washington.

Rice, D. G. 1980. Overview of Cultural Resources on the Hanford Reservation in South Central Washington State. Report submitted to Richland Operations, Richland, Washington.

Rice, D. G. 1981. Archaeological Transects Through Interior Dunes on the Hanford Reservation. Washington. U.S. Department of Energy, Richland, Washington.

Rice, D. G. 1983. Archaeological Investigations at Washington Public Power Supply System Nuclear Plants on the Hanford Reservation, Washinqton. Washington Publi c Power Supply System, Richland, Washington.

Rice, D. G. 1984. Archaeological Inventory of the Basalt Waste Is olation Project. Hanford Reservation. Washinaton. SD-BWI-TA-007, Rockwe11 Hanford Operations, Richland, Washington.

Rickard, W. H., R. E. Fitzner, and C. E. Cushing. 1981. "Biological Colonization of an Industrial Pond." Environ. Cons. 8:241-247.

Rickard, W. H., and L. E. Rogers. 1983. "Industrial Land Use and the Conservation of Native Biota in the Shrub-Steppe Region of Western North America." Environ. Cons. 10:205-211.

Rickard, W. H., and D. G. Watson. 1985. "Four Decades of Environmental Change and Their Influences Upon Native Wildlife and Fish on the Mid-Columbia River, Washington, U.S.A." Environ. Cons. 12:241-248.

Rogers, L. E., and W. H. Rickard. 1977. Ecology of the 200 Area Plateau Waste Management Enyirons: A Status Report. PNL-2253, Pacific Northwest taboratory, Richtand, Waśnington.

Rohay, A. C. 1987. Earthquake Focal Mechanisms. Recurrence Rates, and Deformation in the Columbia River Basalts. RHO-BW-SA-666 P, Rockwe11 Hanford Operations, Richland, Washington.

Rohay, A. C. 1989. Earthquake Recurrence Rate Estimates for Eastern Washington and the Hanford Site. PNL-6956, Pacific Northwest Laboratory, Richland, Washington. 
Scott, M. J., D. B. Belzer, R. J. Nesse, R. J. Schultz, P. A Stokowski, and D. C. Clark. 1987. The Economic and Community Impacts of Closing Hanford's $\mathrm{N}$ Reactor and Nuclear Materials Production Facilities. PNL-6295, Pacific Northwest Laboratory, Richland, Washington.

Scott, M. J., D. B. Belzer, S. J. Marsh, D. M. Beck, R. W. Schultz, S. A Harkreader. 1989. Hanford and the Tri-Cities Economy: Review and Outlook. January 1989. PNL-6813, Pacific Northwest Laboratory, Richland, Washington.

Smith, W. C., M. L. Uebelacker, T. E. Eckert, and L. J Nickel. 1977. An Archaeological - Historical Survey of the Proposed Transmission Power Line Corridor from Ashe Substation Washington to Pebble Springs Substation, Oregon. Washington Archaeological Research Center Project Report 42. Washington State University, Pullman, Washington.

Smith, R. M. 1980. 216-B-5 Reverse Well Characterization Study. RHO-ST-37, Rockwel1 Hanford Operations, Richland, Washington.

Spier, L. 1936. "Tribal Distribution in Washington." General Series in Anthropology No. 3. George Banta Publishing Co., Menasha, Wisconsin.

State of Washington, Office of Financial Management (OFM). 1989. 1988 Population Trends for Washington State. Olympia, Washington.

Stone, W. A, D. E. Jenne, and J. M. Thorp. 1972. Climatography of the Hanford Area. BNWL-1605, Pacific Northwest Laboratory, Richland, Washington.

Stone, W. A, J. M. Thorp, 0. P. Gifford, and D. J. Hoitink. 1983. Climatoloqical Summan for the Hanford Area. PNL-4622, Pacific Northwest Laboratory, Richland, Washington.

Swanson, D. A., T. L. Wright, P. R. Hooper and R. D. Bentley. 1979. Revisions in Stratigraphic Nomenclature of the Columbia River Basalt Group. U.S. Geological Survey Bulletin 1457.

Tallman, A. M., K. R. Fecht, M. C. Marratt, and G. V. Last. 1979. Geology of the Separations Areas Hanford Site. South-Central Washington. RHO-ST-23, Rockwe11 Hanford Operations, Richland, Washington.

Trafzer, C. E., and R. D. Scheuerman. 1986. Reneqade Tribe: The Palouse Indians and the Invasion of the Inland Pacific Northwest. Washington State University Press, Pullman, Washington.

U.S. Department of Energy (DOE). 1982a. Environmental Impact Statement, Operation of PUREX and Uranium Oxide Plant Facilities, Hanford Site. Richland, Washington. and Addendum. D0E/EIS-0089D-0084, U.S. Department of Energy, Washington, D.C. 
U.S. Department of Energy (DOE). 1982b. Site Characterization Report for the Basalt Waste Isolation Project, DOE/RL 82-3, $3^{\text {'Vols., Rockwe11 Hanford }}$ Operations for the U.S. Department of Energy, Washington, D.C.

U. S. Department of Energy (DOE). 1986. Draft Environmental Assessment, Reference Repository Location. Hanford Site. Washington. DOE/RW-0070, U.S. Department of Energy, Washington, D.C.

U. S. Department of Energy (DOE). 1987. Final Environmental Impact Statement, Disposal of Hanford Hiah-Level and Transuranic Wastes, Hanford Site, Richland. Washinqton. DOE/EIS-0113, Vol.I-III, U.S. Department of Energy, Washington, D.C.

U.S. Department of Energy (DOE). 1988. Consultation Draft: Site Characterization Plan, Reference Repositorv Location. Hanford Site, Washinaton. DOE/RW-0154, Vol. 2 of 9, U.S. Department of Energy, Washington, D.C.

U.S. Department of Interior (DOI). 1986. "Endangered and Threatened WiTdI if e and Plants," Federal Reqister, $50 \mathrm{CFR}$, Part 17.

U.S. Energy Research and Development Administration (ERDA). 1975. Final Environmental Impact Statement of Waste Management Operations. Hanford Reservation, Richland, Washington, 2 Vols. ERDA-1538, Washington, D.C.

U.S. Nuclear Regulatory Commission (NRC) . 1982. Draft Environmental Statement Related to the Construction of Skaqit/Hanford Nuclear Project, Units 1 and 2. Docket Nos. STN 50-522 and STN 50-523. Puget Sound Power and Light Company, Pacific Power and Light Company, the Washington Water Power Company, Port7and General Electric Company. NUREG-0894, Nuclear Regulatory Commission, Washington, D.C. and Washington State Energy Facility Site Evaluation Council, Olympia, Washington.

United Way. 1986. 1986 Annual Report. Kennewick, Washington, United Way of Benton and Franklin counties.

Washington Public Power Supply System (WPPSS). 1981. Final Safetv Analvsis Report for Washington Nuclear Plant Number 2 (WNP-2). Washington Public Power Supply System, Richland, Washington.

Washington State Natural Heritage Program. 1987. Endangered, Threatened and Sensitive Vascular Plants of Washington. Washington State Department of Natural Resources, Olympia, Washington.

Watkins, N. D., and A. K. Baski. 1974. "Magnetostratigraphy and Oroclinal Folding of the Columbia River, Steens, and Owyhee Basalts in Oregon, Washington, and Idaho." American Journal of Science, 274:148-189.

Watson, D. G. 1970. Fal1 Chinook Salmon Spawning in the Columbia River Near Hanford 1947-1969. BNWL-1515, Pacific Northwest Laboratory, Richland, Washington. 
Watson, D. G. 1973. Fal1 Chinook Salmon Population Census. BNWL-1750, Pacific Northwest Laboratory, Richland, Washington.

Watson, E. C., C. D. Becker, R. E. Fitzner, K. A. Gano, C. L. Imhoff, R. F. McCal lum, D. A Myers, T. L. Page, K. R. Price, J. V. Ramsdell, D. G. Rice, D. L. Schreiber, L. A. Skumatz, D. J. Sommer, J. J. Tawil, R. W. Wallace, and D. G. Watson. 1984. Environmental Characterization of Two Potential Locations at Hanford for a New Production Reactor. PNL-5275, Pacific Northwest Laboratory, Richland, Washington.

Westinghouse Hanford Company (WHC). 1989. Westinshouse Hanford Company 100 Area Environmental Releases for 1988. WHC-EP-0165-1, Westinghouse Hanford Company, Richland, Washington.

Wolf, E. G. 1976. Characterization of the Benthos Communitv. In: Final Report on Aauatic Ecological Studies Conducted at the Hanford Generating Project, 1973-1974. Prepared for Wash ington Public Power Supply System under Contract No. 2311201335 to United Engineers and Constructors, Inc. Battelle, Pacific Northwest Laboratories, Richland, Washington.

Wolf, E. G., T. L. Page, and D. A. Neitzel. 1976. "Phytoplankton Community: Primary Productivity, Pigment Concentration, Species composition and Relative Abundance of Phytoplankton and Physiochemical Analysis, " Section 2. In Final Report on Aauatic Ecological Studies Conducted at the Hanford Generatinq Project, 1973-1974. WWPPSS Columbia River Ecological Studies, Vol. 1. Battelle, Pacific Northwest Laboratories, Richland, Washington. 


\section{DISTRIBUTION}

No. of

\section{Copies}

\section{OFFSITE}

12 DOE Office of Scientific and

Technical Information

DOE Public Reading Room

Forrestal Building

1000 Independence Avenue \$V

Washington, DC 20585

DOE Public Reading Room

P.O. Box 800

Richland, WA 99352

DOE Savannah River Operations

P.O. Box A

Aiken, SC 29808

EPA, Region 10

1200 Sixth Avenue

Seattle, WA 98101

Gonzaga University

Crosby Library

E 502 Boone

Spokane, WA 99258

Portland State University

Branford Price Miller Library

934 SW Harrison

Portland, OR 97207

Richland Public Library

Swift and Northgate

Richland, 99352

University of Washington

Library

MS: $\quad F M-25$

Seattle, WA 98195
Washington State University Library

Owen Science and Engineering Center

Pullman, WA 99164-3200

Washington State, Energy Facility Site Evaluation Counci 1

4224 6th Ave. S.E.

Bldg. 1, PY-11

Lacey, 98504-8911

Washington State Department of Health

1112 S. Quince

ET-21

Olympia, 98504

10 Dr. Elisabeth A. Stull

Argonne National Laboratory

9700 S. Cass Avenue

(EES/362-G316)

Argonne, IL 60439-4815

\section{ASITE}

3 DOE Richland Operations Office

C. A. Ashley

E. A. Erichsen

L. D. Romine

Westinghouse Hanford

Operations

A. J. Duckett 
No. of

Copies

36 Pacific Northwest Laboratory
J. C. Chatters
C. E. Cushing (20)
D. L. Hadley
D. J. Hoitink
I. C. Nelson

No. of

Copies

D. R. Payson

T. M. Poston

A. C. Rohay

M. J. Scott

W. L. Templeton

R. W. Wallace

Publishing Coordination

Technical Report Files (5) 